ORHL --6021

DE?: 006243

Distribution Category UC-48

Contract No. W-7405-eng-26

EIOLOGY DIVISION

PROGRESS REPORT

For Period of August 1, 1982 - September 30, 1383

Date Publi:hed: january 1984

R. A. Griesemer, D1rector

T. T. Ode11, Assoclate Director

\title{
SECTION HEADS
}

G. A. Bingham, Laboratory Animal Resources

C. S. Cook, Administration and Services

J. L. Epler, Comparative Genetics

R. J. M. Pry, Cancer

P. C. Hartman, Molecular Genetics

L. B. Russell, Manmalian Genetics and Reproduction

H. R. W1tsch1, Toxicology

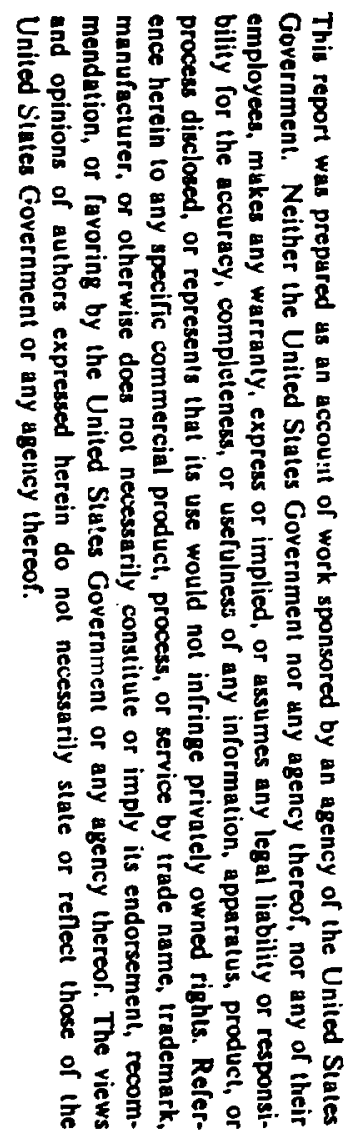

OAK RIDGE NATIONAL LABORATORY

Oak R1dge, Tennessee 37831

operated by

UNION CARBIDE CORPORATION

for the

DEPARTMENT OF ENERGY 


\section{Contents}

INTRODUCTION AND DIVISION OVERVIEW . . . . . . . . . . . . vi v

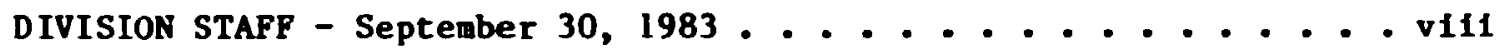

RESEARCH ACTIVITIES . . . . . . . . . . . . . . . . 1

MOLECULAR GENETICS SEction . . . . . . . . . . . . . . . 1

Section Overview ....................... . . 1

Mechanisms of Mutagenesis and DNA Repair .......... 3

Control of Transcription in Eukaryotic Systens

and Studies of DNA-Protein Interaction ......... 5

Structural Aspects of DNA in 1 ts Replication and Repair . . . 7

Processing of RKA in Yeast ................ 12

Modification of Structures and Functions of Proteins

Involved in Phage T5 DNA Keplication .......... 13

Nucleic Acid Blochenistry of Cells ............ 16

Chromosome Chemlstry .................. 17

Nucleosowe and Chromatin Biophysics ............ 18

X-Ray Diffraction .................... 20

The Structure and Organization of the Eukaryotic Genome

with Special Emphasis on Satellite DNAs and the

Phenomenology and Control of the Crustacean Hiolt Cycle . - 22

Enzywe and Gene Regulation: Normal Mechanisms

and Responses to Toxic Metal Ions ............ 25

DNA Dosimetry Applied to Problems In Genetic Toxicology . . . 28

Respiration Shut off in Escherichia coli after

Far-UV Irradiation ............... 29

Regulation of Transport Systems in Cultured Mammalian Cells . 31

Theoretical and Applied Cryobiology ........... 32

Protein Chemistry and Enzyme Mechanisms......... 35

COMPARATIVE GENETICS SECTION . . . . . . . . . . . . . . 39

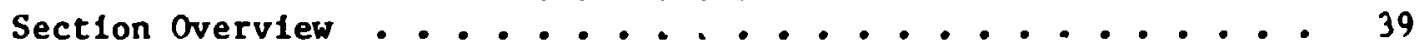

Comparative Mutagenes1s............... 41

Mammalian Cell Genetic Toxicology ............. 50

Mammalian Cytogenetics ................. 55

DNA Repair In Human Cells .................. 62

Genetic Analysis of DNA Repair In Man with Cell Hybrids . . 67

Genet1c Dissection of DNA Repair In Xeroderma Pigmentosum

Cells ................... 68

Genetic Basis of Mutagenesis and Carcinogenest: . . . . . 70

Mammalian Blochemical Geretics ............. 75

Drosophila Cytology and Genetics ............. . 79

Microbial Mutagenesis and Cell Division.......... 81

Genet 1cs of Repa1r of Rad1ation Damage to DNA In Bacter1a . 83

Analysis of Teratogens and Potential Teratogens

Using PETAX (Frog Embryo Teratogenes1s Assay: Xenopus) . 86 
MAMMALIAN GENETICS AND REPRODUCTION SECTION . . . . . . . . . .

Section Overview . . . . . . . . . . . . . . . . . .

In-Depth Study of Chemical Kitagenesis in Mouse Gerw Cells Using N-Ethyl-N-N1trosourea (ENU) as a Model Mutagen ...

Use of Methylnitrosourea (MNU) as a Model Mutagen to Explore Biological Variables Affecting Mutagenicity In Mouse Germ Cells .......................

Use of MNU-ENU Double Exposure in the Spot Test to Explore the In Vivo Action of an $0^{6}$ Alkyl Trarsferase ......

Specific Locus Studies with DBCP and HMPA ..........

The Effects of Inhaled Ethylone Oxide on Induction of

Heritable Gene Mutations ................

Her1table Translocation and Dominant-Lethal Mutation Dose-

Response Studies with Inhaled Ethylene Oxide . . . . .

Non-Breeding-Test Methods for Studying Induction of Dominant Skeletal Mutations are Easily Applied to Strain Used In Specific-Locus Experiments . . . . . . . . . . .

Breeding-Test Experiment Shows Transaission of Many E:Vi-Induced Mutations ...............

Detailed Analysis of Radiation-Induced Litter-Size Reduction In Specific-.ocus Experiments ............ 104

Cytóenetic Analysis of Sterile Male Progeny from MutagenExposed Parents . . . . . . . . . . . . . . . .

Response of Mouse Spermatogonial Sten Cells to X-Ray Induction of Herit ible Peciprocal Translocations ..... 100

DNA Target Sites Associated with Chemical Induction of Dominant-Lethal Mutations and Heritable Translocations In Mice . . . . . . . . . . . . . . . . . . . .

Early Embryonic Lethality Induced by Seed 0118 in Female Mice Treated Prior to Insemination ..............

A Restudy of the Effectiveness of Ingested Ethyl Alcohol to Cause Nondisjunction In Mouse Docytes .........

Development of Tests That Detect Induction of Melotic Nondisjunction in Mammals . . . . . . . . . . . 112

Evaluation of Existing Mutagentcity Bloassay for Purposes of Genet1c Risk Assegsment ............. 114

Chemical Dosimetry Studies in Mammalian Germ Celis.... 115 DNA Repair Studies in Mamnalian Germ Cells ......... 116

DNA Damage in Mammalian Sperm Assayed by Alkaline Elution . . 118

Analyses of Specific Reglons of the Mouse Genome . . . . 119 Synaptonemal Complex Study of Nonhomologors Synapsis In X-Autosome Translocations Sheds Light on X-Y Disfunction Mechanisms ..................... Involvement of the $\mathrm{Y}$ Chromosome in Translocations ...... Melotic Segregation in Partiaily Sterile Male Translocation Heterozygotes ......................

High-Pesolution Banding of Mouse Prometaphase-Prophase Chromosomes ...... . . . . . . . . . . .

Circadian Rhythms of Spermatogonial Stem Cells ...... 125 
The Ef cect of Age on the Spernatogonial Stem Cell Population of the Mouse .................. 126

Lack ef Effect of DBCP on the Mouse Testis . . . . . . 127

Analysis of Spontaneous Early Embryon:= Lethality in Mice . - 127

Establishment of an Embryo-Freezing Program for the

Preservation of Genetic Stocks ........... 129

TOXICOLOGY SECTION ........................ 131

Section overvieu .................... 131

Systentc Toxtcology .................... 133

Induction and Progression of Neoplasia in Tracheal

Epitheltum ................... 138

Inhalation Toxicology ................... 141

In Vitro Studies of Cutaneous Toxicity and Chemical-Skin

Interact Ions .................. 144

Dosinetry of PAH in Skin Carclnogenesis . . . . . . . 147

Radiation Imunology .............. 148

CANCER SECTION ........................ 151

Section overview .................... 151

Molecular Genetics of Carcinogenesis ........... 155

Regulation of Gene Expression .............. 159

Tumor Cell Surface Protelns............... 163

Cytometr1cs . . . . . . . . . . . . . . . . . 167

Metabol1c Act1vation and Carcinogen Metabolism . . . . . 169

Radiation Carcinogenesis . . . . . . . . . . . 173

Effects of Androgens and Antlandrogens on the Induction

of Muse SkIi Paptllomas by Phorbol Ester Tumor Promoters • 180

EDUCATIONAL ACTIVITIES . . . . . . . . . . . . . 183

University of Tennessec ak Ridge Graduate School

of Blomedical Sclence; ................ 183

Postdoctoral Traintng Prngrams .............. 184

Undergraduate Train1ng Program .............. 184

APPENDICES ......................... 185

Advisory Comittee ................... 185

Semlnar Programs ...................... 185

In:ernal Seminars and Journol Clubs ........... 185

Seminars by Outside Speakers . . . . . . . . . . . 186

Research Conferences ................... 190

Extramural Activitles.................... 190

1. Officer of Soctety . . . . . . . . . . . 190

2. Soctety Committees ............... 191

3. Advisory Comnttees ............... 192

4. Edtortal Boards ................ 195

5. Awards . . . . . . . . . . . . . 197

Abstracts for Technical Meetings .............. 198

Financial Summary and Personnel Distribistion . . . . . . . 209 


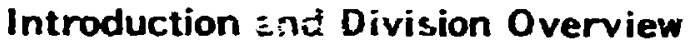

\author{
R. A, GRIESEMER
}

\begin{abstract}
The Blology Division is the component of che Oak Ridge National Laboratcry that investigates tixe potential adversis health effects of energy-related substances. Alrost $8: 11$ the work iff the DIvision is experimental and utilizes mamallan and submanxs?lar systers to obtain data for fredicting and underatandirg hazards to h: ra: health. Work directiy with the human speries is linted to studies of irdividuals naturally or accldentally exposes to er:vironmen:al agents and to Investigations utflizing fluits and :ells that can ise wialned from humans without harm.
\end{abstract}

The energy-related substruces of Interest are both phusical and chemical. Among the physirai agents, wajor interest is focused on the health effects of neutron and heavy lon radiatlons on antmals with particular attention to the responses to Low doses, the relative biological effectiveness of varlous forms of radlation. and comparisons with gamma radiation for which a considerable data bas? exists. Among the chemical agents, spectal emphasis is picosd on probles is associated with the emerging energy technologies, notably synthetlc fuel: of fossil origin. Since the energy-relatcd substances to which people may be exposed iend to be complex mixtures of chentcals, the Jiolsion's activ:ties soncencrate on the adverse health effects from chemicil-iemical or cheniral-physical interactions and on methods to evaluate th: effects of comp?ex mixturas.

The Division's scicirigts ure organized into whiti-dibciplinary teams that investigate the sajo: isease endpcints: mutageniclty, reproductive disorders, carrinogentely, and actite and chrontc toxicticy. A necessary part of such studies is paraliel investigations of the normal structure and function of the body and the ways tie body responds to injury. The studies range from molecular and callular to the use of whole animals. of the vartous organ systedis, par:icular atreition is pald to the stin and the respiratory tract, :wo major interfac: between the body and environmental agents.

The resources avallable for tie Division's activities during the report perlod fncluded a staff of apfroximately 57 at the doctorate level, 149 support personnel, 43 joctoral students, 9 postdoctoral students, and an average of 50 other visiting professors, students, and scientists. The Division occupies $327,000 \mathrm{sq}$. ft. of laboratory space with spectallzed factlities for 250,000 animals, a cllection of 1,000 muiant stocks of mice, barrier factilties for the s,fe handling of hazardous substances, laboratorles for recomblinant DNA re:earch, radiation sources, a facility for the production of large volum.s of cells or microrrgantsms, and a library. The Division also makee extensive use of resource, in other Divisions of the Oak Ridge National Laboratory incliding the Information 
Centers for mugenesis and toxicology and the Analytical Chemistry Division where collaboration in research has been sopecially fruttful.

A significant change in resources frca the previous year was a planned reduction in the anount of laboratory space occupied by the Division. The Biology Division had experienced a 407 reduction in the size of its staff In the previous two years due to budget restrictions. To conserve operatIng costs, the remaining staff meners and their prograns were relocated this year so that portions of the Blology Division space could be made avallable for lease by other divisions or Lemporarily shut down.

Technical progress during this report period is described in the following sections but a few highlights of Division activitie: deserve special mention. Of the Division's 220 publications last year, wore than a third were co-authored by predoctoral and/or postdoctoral students. About 307 of the publications were coauthored by scientists at other instit:tions, Indicating extensive collaborative interactions with universities. As Indicated In the body of the report, the staff menbers of the Division continue to be active as officers and menbers of scientific societies, as advisors to federal agencies, and as nembers of editorial boards. Two senior members of the Division, Drs. Liane B. Russell and John B. Storer, recelved special honors. Both were named Corporate Fellows by Union Carbide Corporation in recognition of their outstanding, Internationally recognized research accomplishments in mannallan genetics and radiation biology, respectively. Designation as a Corporate Fellow is a special distinction because there are only 18 Corporate Feilows in the Nuclear Division of the Union Carbide Corporation and only 47 Fellows in the entire Corporation.

The body of this report provides sumaries of the ains, scope and progress of the research of groups of Investigators in the Division unA... the period of August 1, 1982, through Septenber 30,1983. At the end of each summary is a list of publications covering the same period (published or accepted for publication). For conventence, the summaries are assembled under Sections in accordance with the current organizational structure of the Blology Diyision; each Section begins with an overview. It will be apparent, however, that currents run throughout the Division and that the various prograns support and interact with each other.

In addition, this report includes an outline of educational acilvitles, a listing of the members of the Advisory Comattee, seminar programs in the Division, research conferences sponsored by the DIvision, extranural activities of staff members, abstracts for technical meetings by staff, snd a table that summarizes funding and personnel levels for fiscal year 1983. 
F. C. Hartean - Section Head S. P. Sands - Secretary

b. A. Arnold 1

G. J. Buntek ${ }^{2}$

E. C. Uberbacher ${ }^{3}$

S. F. Carson

W. E. Cohn 1

J. S. Cook

P. W. Braden

C. J. Shaffer

W. D. Dawson 3

R. S. Foote $e^{4}$

R. R. Fujimura B. C. Roop

F. C. Hartman C. D. Stringer

M. I. Donne11y

E. H. Lee $^{3}$

R. B. Jacobson

E. K. W11kerson

E. B. Wright

W. E. Masker

M. E. Bollng

M. A. Maupin

P. Mazur

K. W. Cole

S. Mitra

J. G. Fcezell

S. K. Nivozi

$$
\text { M. L. Yette }
$$

A. L. $01 \operatorname{lns}^{4}$ J. H. PInch ${ }^{4}$

D. E. $01 \operatorname{lng}^{4}$

J. M. Harp ${ }^{4}$

L. H. Cachetro 4

R. 0. Rahn

U. Schneider 4

H. G. Sellin

D. M. Skinner
R. F. Fowler 4

D. L. Mykles 3

A. L. Stevens

P. A. Swenson

I. L. Norton

J. R. Totter 4

E. Volkin

C. H. WeI

M. H. Jones

Electron Mi zroscope Pac1lity

D. P. AII1son

M. Rorvik 4 
COAPARATIVE GENETICS SECTION

J. L. Epler - Section Head

N. P. Bair - Secretaiy

H. I. Adler

H. D. Crow

R. Machanoff

H. Au

T. Ho

D. BIllen 4

J. N. Dumont

J. L. Epler

R. G. Epler

R. F. Grell

C. T. Hadden 4

L. Oggs

A. K. Hsie

P. A. Brimer

S. H. Perdue

L. $\operatorname{Rec} 10^{4}$

R. L. Schenley

R. F. Kimbal1 1

P. A. Lalley

K. B. Allen

F. W. Larimer

C. E. NAx

A. A. Hardigree

L. M. Kyte

R. D. Hikerson

R. A. Popp

D. M. Popp

R. J. Preston

M. L. Chandler

P. C. Gooch

H. E. Luippold

H. S. Payne

J. D. Regan

W. L. Carrier

W. C. Dunn

A. A. Francis

H. H. Lee

B. G. Stanford

P. A. Charp 3

J. R. San Sebastian 4

T. W. Schultz 4 


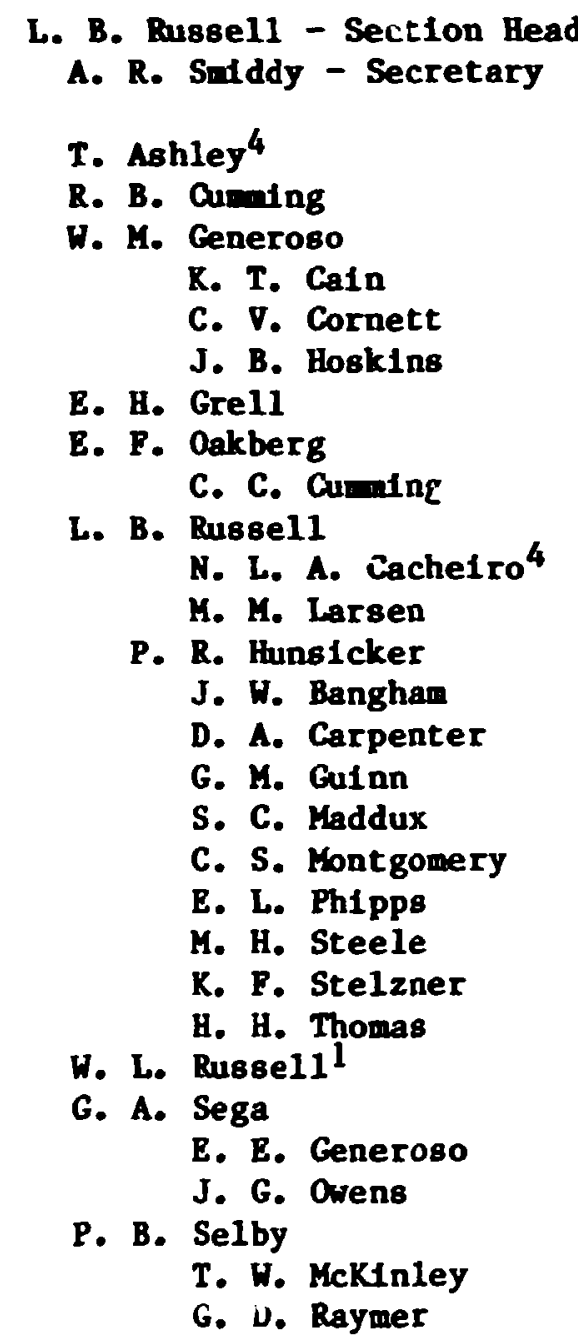

Mammalian Genetics Animal Pacility

J. R. Inman
C. C. Cherry
R. R. Deal
K. F. Elliott
H. F. Guinn
H. J. Hardin
E. Hawkins
J. H. Hawkins, Jr.
H. G. Hodge
J. W. Jackson
E. L. Jones
J. Lewis, Jr.
G. A. McBee
C. S. R1cheson
J. E. Steele
R. D. Thomas
E. L. W11kerson
B. L. Wood


TOXICOLOGY SECTION

H. R. Witschi - Section Head

J. M. Shover - Secretary

H. F. Goad 4

J. Y. Kao

J. W. Hall

S. M. Lock

F. J. Stenglein, Jr.

A. C. Marchok

D. H. Martin

P. Netteshein 4

E. H. Perkins

H. C. KIIma

N. W. Revis ${ }^{4}$

L. R. Shugart

B. $\therefore$. Chastain

L. H. Smith

L. C. Gipson

T. J. Stevens

L. H. Woods

A. F. Tryka ${ }^{4}$

L. C. Haters

S. I. Simms

H. R. Witschi

M. J. Whitaker

R. C. Lindenschmidt ${ }^{3}$ 
CANCER SECTION

R. J. M. Fry - Section Head

J. F. Young - Secretary

G. A. Lraslawskg

A. Brown 1

A. A. Stuart 4

R. A. Davidson

R. J. M. Fry

L. A. Triplett

S. J. KenneI

L. J. Foote

P. K. Lankford

G. L. McNabb

F. T. Renney

G. R. Holloway

K. W. Isham

D. Hoffman ${ }^{3}$

L. A. Stringfellow 3

K. Lee

R. C. Mann

R. E. Hand

J. K. Selkirk

B. K. Mansf 1eld

P. A. Nikbakht

S. M. Tong

A. Solomon

J. B. Storer

R. W. Tennant 4

M. Terzaght

C. K. Mckeown

R. L. U11rich

N. D. Bowles

M. C. Jernigan

S. P. Ogle

R. C. Satterfield

W. K. Yang

C. Koh

F. B. Myer

L. E. Roberson

D. M. Yang

H1stotechnology Laboratory

J. W. Wesley

v. D. Wright 
THE UNIVERSITY OP TEMNESSBE - OAR RIDGE GRADUATE SCHOOL OF BIOARDICAL SCIENCES

H. B. Barnett, Director

D. Billen

E. A. His8

D. E. Oling

C. Sounoff

N. McCarthy

B. L. Moorman

A. Wry

GRADUATE STUDENTS

M. J. Aardema

R. L. Allen

S. P. Ayer

L. A. Balogh

C. L. Cadilla

J. S. DeHart

J. B. Fishman

J. M. Flanagan

R. B. Flint

R. M. Flynn

k. Furkes

M. J. Gardner

D. F Cebhardt

M. N. Heartlein

R. J. Hellwig

J. Hotchkis8

A. C. Johnson

N. B. Kuenmerle

C. Lee

K. L. Moore

S. L. Niemann

K. N. Nikbakht

L. E. Nottingham

A. E. Roberson

R. S. Rothrock

B. L. Schaefer

L. E. Sendelbach

A. C. Sozer

L. P. Stankowsk1

M. H. TInda I

G. N. Tjossem

D. J. Trently

B. Van Houten

W. J. Wastlenko

C. J. Wawrzyniak

R. R. Weiso

R. A. Winegar

C. R. Wobbe

D. S. Woodard 
ADMIMISTRATIVE AND DIVISIUN SERVICES

C. S. Cook - 'jection Head

A. D. Dento - Secretary

C. R. Abercromble

J. Harrto 5

C. S. Cook

H. C. Carter

N. G. Crowe 6

N. P. Hair

S. M. Hall

D. B. Jones

N. P. Kwaak

M. G. PIckard

K. J. Rader

C. S. Rains

S. P. Sands

B. G. Selmer

J. M. Shover

A. R, Sniddy

E. H. Thomp 3on

J. F. Young

H. J. Hicks 7

L. A. Stephens 7

D. L. Million 8

J. A. Otten

M. P. Harris

R. L. Johnst on

L. H. Phipps

S. E. Freeman

M. B. Jones

B. F. Lew1s

H. C. Majors

F. S. Martin

H. G. Mtchell

S. L. Scott

M. S. Summers

T. T. Vann ${ }^{9}$

K. D. Hopper

L. H. Veach

A. G. Vest 6 
LABORATORY ANIMAL RESOURCES

G. A. Binghan - Section Head

w. B. Anthony

J. W. Jarnagin

M. Phillips

H. J. Satterfield

E. T. Shephard

E. M. Garrison

W. L. McKinney, Jr.

R. Davis, Jr.

V. T. McKee, , Jr.

J. R. Wells

E. H. Gaines

J. L. Davidson

E. E. Sharp

B. E. Sise

J. E. Whittlesey

1 Consultant

${ }^{2}$ Loanee - Chemistry Division

3 Postdoctoral Investigator

${ }^{4}$ Guest Assignment

5Loanee - Maintenance Division

6Loanee - Information Division

7 Loanee - Engineering D1vision

8Loanee - Computer Sciences Division

${ }^{9}$ Loanee - Finance and Materials Division 


\section{Superscripts after Staff Names \\ on Research Summaries}

$\mathbf{1}_{\text {Student, University of Tennessee-Oak Ridge Graduate }}$ School of Blomedical Sciences

Information Division

${ }^{3}$ Guest Assignment

${ }^{4}$ Postdoctoral Investigator

${ }^{5}$ Chemistry Division

$6_{\text {Health and Safety Research Division }}$

${ }^{7}$ Consultant

${ }^{8}$ Student, Southern Colleges University Union

${ }^{9}$ Computer Sciences Division

${ }^{10}$ Paculty Research Participant, Oak Ridge Associated Universities

${ }^{11}$ Student, Great Lakes Colleges Association

12 Student Research Parilcipant, Oak Ridge Assoclated Universities

${ }^{13}$ Student, Life Sciences Department, University of Tennessee 


\title{
Research Activities
}

\author{
Molecular Genetics Section
}

SECTIOP OVERVIEW - F. C. HARTMAN

As part of the Department of Energy's life sciences program, our mission is to investigate basic aspects of adverse health effects of energy production. Since nuclear reactors and fossil fuels are our nation's major energy sources, interactions of radiation and chemicals derived from fossil fuels with btological systems are of prinary concern. The more profound clinical manifestations of human exposure to these agents may include cancer, genetic damage, birth defects, and acute toxic poisoning, all of which represent perturbations of normal cellular pronesses. There is such a vast array of potentially damaging agents that to attemit to asscss each uf their consequences singly and in combinations is likely doomed to failure. The only hope is to develop sufficient fundamental understanding of the structure, blochemistry, and physiology of cells and of cellular repair and defense mechanisms to permit conclusions about classes of action and classes of cellular responses. Thus, the Section has evolved a comprehensive, diversified program for probing the multifaceted aspects of health problems associated with energy production and utilization.

Cancer, mutations and birth defects share common origins that entail modification of gene structure or alterations in nucleic acid enzymology. Major emphasis is therefore placed on gene structure and function. This central theme includes studies of the structure of DNA and chromatin, the interaction of nucleic acids with environmental agents, replication and ranscription of DNA as well as their regulation, enzymology of repair of DNA damaged by chemicals o: radiation, and molecular genetics. During the past year, notable accomplishments in these general areas of molecular biology include the following:

(1) $0^{4}$-Ethylthymine is a potentially promutagenic and procarcinogenic base. To evaluate its mutagenic properties and to characterize its repair pathway, isotopically labeled $\underline{0}^{4}$-ethylthymidine triphosphate has been synthesized and incorporated into synthetic DNA.

(2) Ordered nucleoprotein complex formation 18 a prerequisite for efficient yet specific transcription by enriching for essential protein components that interact with the template. These complexes contain chromosomal nonhistone and possibly nuclear matrix proteins.

(3) As a prerequisite to cloning and site-specific modification of the T5 DNA polymerase gene, the sensitivity of bacterial transformation by restriction fragments of T5 DNA hs8 been greatly enhanced by devising improved experimental conditions. 
(4) A variety of chemical utagens are potent inhibitors of ribonucleotide blosynthesis and hence lead to an inbalance of nucleotide pools. Recent results suggest a correlation between these imbalances and the observed atagenic and toxic effects of the chemicals.

(5) A nunber of variants of a complex, G+C-rich (637) satellite DMA have been cloned and sequenced. Because of the arrangevent of interspersed dunains of simple sequences tich in guanine and cytosine, the satellite provides a model system for the study of the influence of primary structure on secondary and tertiary structure of DNA.

(6) A new ultrastructural technique, electron wcroscope tomography, has been developed which pernits an accurate three-dimensional construction of electron-density distributions within a sectioned and stained biological specimen.

(7) In Bscherichia coli radiation and chemicals which danage DNA are known to Induce certain SOS functions, such as utagenesis, which require the lexA $A^{+}$and recA $A^{+}$gene produsts. Another of the functions, induced sinutoff of respiration, has now been shown to also require exonuclease $V$ which is determined by the $\underline{\operatorname{rec}}^{+}$and recC $^{+}$genes.

Membrane biology is also considered of prime relevance to the Section, as membranes can be considered interfaces between the iratracellular wetabolic machinery and the external environment. In many cases, membranes are effective barriers to noxious chemicals and as such preclude the necessity of repair pathways; in other cases, membrane components are rendered inactive by combination with exogenous agents and repair mechanisms wust then be invoked. Current studies emphasize the dynamic aspects of cell surfaces, including their ispair by turnover, protein sorting in the continual exchange of cell surface with a large intracellular membrane pool, and the controls on the differentiation of membrane function. Another aspect of cellular-environmental interactions and membrane integrity which receives emphasis 18 cryobiology. Recently, the long-held view that injury to cells subjected to slow freezing is due to osmotic dehydration has been challenged. New data suggest that survival is primarily dependent on the fraction of intracellular water remaining unfrozen rather than on the salt concentration therein.

Given the absolute dependence of life processes on catalysis and the adverse consequences of altering catalytic events, our long-standing, interests in enzyme mechanisms continues. A major activity is the desigit of affinity labels for the characterization of catalytic sites. These studies also relate to toxicology in that acute toxic poisoning frequently reflects the specific interaction of a chemical with a key metabolic enzyme; e.g. the Inactivation of acetylcholine esterase by nerve gases. Recent advances include (1) characterization of the $\mathrm{CO}_{2} / \mathrm{Mg}^{2+}$-1nduced activation of the $\mathrm{CO}_{2}$-fixation enzyme from Rhodospirillum rubrum, (2) design of new active-site specific reagents for the $\mathrm{CO}_{2}$-fixation enzyme, (3) development of an improved procedure for affinity chromatography of GTP-cyclohydrolase, (4) detection of an inducible 
cadnium-binding protein in Drosophila whose concentration appears to reflect the degree of resistance to cadmiun toxicity, and (5) purification of a $\mathrm{Ca}^{2+}$-activated neutral protease inportant in the atrophy of muscle in nolting crustaceans.

Although all of our studies are at least partiaily funded by DOE, supplemental support through grants from MH, NSF, and USDA pernits a somewhat broadened scope with enhanced scientific productivity. Declines In DOE budgets have virtually necessitated the securenent of funds from other agencies to provide postdoctoral positions and other supportive personnel so essential to maintaining cospetitiveness.

\title{
MECHANISHS OF MUTAGENESIS AND DNA REPAIR
}

\author{
W. E. Masker \\ L. A. Dodson ${ }^{1}$ \\ N. B. Kuemerle 1
}

Chemical and physical factors associated with energy production have the potential to cause DNA damage that can contribute to human health problews. If meaningful judgments are to be made regarding the health risks associated with energy technologies, it is imperative that we understand the blochemical mechanisms used by the cell to cope with damage to its genetic material as well as the molecular mechanisms responsible for mutagenesis associated with DNA damage. The aim of this research program is to learn more about DNA repair pathways and to study factors that affect the fidelity of DNA replication and repair.

One aspect of our research deals with mechanisms of excision repair in Escherichia coli exposed to chemicals or ultraviolet (UV) radiation. During the past year we have focused our attention on the incision proteins that Initiate removal of pyrimidine dimers, benzola]pyrene adducts, and other bulky lesions from DNA. The product of the $E$. coll uvrD gene was 1solated and shown to be important in mediating closure of single strand DNA breaks promoted by the Incision complex coded for by the uvrA, uvrB, and uvrC gene products ( 3 ). Th1s suggests that the uvrD gene product (now known to be a hellcase) is necessary either for dislodging the incision complex from the nicked DNA or for preparing a DNA primer-template configuration sultable for proper repair resynthesis. Studies with mutants defictent in DNA single strand binding protein (ssbA) also show an accumulation of unrepaired incision breaks (5). This is probably due to accumulation of double strand DNA breaks (perhaps caused by exonuclease $V$ ) in gapped DNA that is not protected by a coat of binding protein. Studies on one of the incision proteins (UvrA) have used site directed mutagenesis to generate an interesting new mutation, uvrA276, cloned on a multicopy plasmid and to partially characterize the effects of this mutant protein on excision repair (Lorensen, E., Masker, W., Chase, J., submitted for 
publication). These experiments have suggested that the UvrA protein has more than one active site, that mutant UvrA proteins alcered in different active sites can complement one another, and that the UvrA, UvrB and UvrC proteins form a very stable complex.

Our studies on muagenesis use a system in which bacteriophage T7 DNA is replicatec in vitro and tnen encapsulated into phage heads in vitro so as to form viable $T_{i}$ phage. The system has sufficient accuracy and efficiency to allow studies of in vitro mutagenesis and has, in fact, been instrumental in the first direct demcistration that $0^{6}$-methylguanine is a premutagenic lesion ( 1 ). Our recent work has inproved the efficiercy of the packaging system by optimizing the oswotic strength of the reaction mixture (4) and has demonstrated a role for the T7 gene 6 exonuclease in DNA packaging (Dodson, L., Mrisker, W. E., to be published). These results have improved the usefulness of our packaging systen by raising its effici,ncy above 17 phagi productior per genome equivalent of input DNA and have provided clues regarding the mechanism by which viral DNA is packaged. We have also rsed the packaging sjstem to demonstrate in vitro recombination of restriction fragments of $T 7$ DNA into intact replicating $T 7$ genomes. Further studies with analogues of normal DNA precursors have provided cuggestive evidence that mismatch repair may figure prominently in the degree of mutagenesis detected with our system.

Our work on repair of damaged T7 DNA in host cells induced for the SOS response has shown that inducible repair mechanisms do operate on $T 7$ but that these mechanisms are distinct in several ways from what is normally seen with other types of phage. Inducible reactivation of $T 7$ is independent of both the host umuC gene product and the analogous pKMlOl muc gene product (2). Since $T 7 \overline{D N A}$ synthesis is independent of E. coll host protein, this result argues that the umuc protein may interact with one of the $E$. coll DNA replication proteins to cause increased survival at the expense of decreased fidelity of DNA synthesis as the DNA replication complex attempts to cop; a damaged genome.

3. Docidon, L. A., Foote, R. S., Mitra, S., Masker, W. E., Mutagenesis of Bacteriophage T7 DNA in vitro by incorporation of $0^{6}$-methylguanine during DNA synthesis. Proc. Nat1. Acad. Sc1. USA 79: 7440-7444, 1982.

2. Dodson, L. A., Masker, W. B., Inducible reactivation of bacteriophage T7 damaged by methyl methanesulfonate or UV 1ight. J. Bacteriol. 156: 13-18.

3. Kuemmerle, N. B., Masker, W. E., in in vitro complementation assay for the Escherichia coll uvrD gene product. Nucleic Acids Res. 11: 2193-2204, 1033.

4. Serwer, P., Masker, W. E., Allen, J. L., Stability and in vitro packaging of bacterlophages: effects of dextrans, sugars and polyols. J. Virol. 45: 665-671, 1983.

5. Whittier, R. F., Chase, J. W., Masker, W. E., Repair resynthesis in Escherichla coll matants deficlent in single-stranded binding protein. Mutat. Res., In press. 
CONTROL OF IRANSCRIPTION IN EUKARYOTIC SYSTEMS AND STUDIES OF DNA-PROTEIN INTERACTION

$$
\begin{array}{ll}
\text { S. R. Miyogi } & \text { D. P. Allison } \\
\text { R. J. Hellwig } & \text { M. L. Yette } \\
\text { S. P. Ayer } &
\end{array}
$$

In order to understand the health effects of various agents associated with energy technologies, it is inperative to conduct fundanental studics aived at elucidating the underlying sechanisus involving the genetic material. The control of transcription in eukaryotic systens is a key process at the genetfc level. Investigations in our laboratory are specifically directed towards elucidating the volecular wechanisas of transcription in two animal viral systems, nanely, sinian virus (SV) 40 , and adenovirus 2. We are particularly interested in understanding the mechanisas underlying the initiation of transcription as a key event in gene expression. Since transcription in vivo is known to occur at the level of "chronatin", we are also conducting studies of the transcriptionally active viral nucleoprotein in order to fully understand the regulatory roles of various proteins in viral transcription.

Transcription Scudies. Recently, cell-free systens have been developed from eukaryotic, including human, cells that can be utilized to monitor correct initiation of transcription by eukaryotic RNA polymerase II (the enzyme responsible for synthesizing sessenger RNA) on promotercontaining viral or cloned DWA templates. Besides measuring promoter strength, capping of the RNA product can be demonstrated in these systems. Low activities for splicing and chain termination can also be shown.

Previous siudies from our laboratory have shown that the interaction of template DNA with crude cell-free transcription extracts from Hela cells leads to the formation of ordered nucleoprotein complexes (NPCs) that have a nuber of structural sinflarities wth eukaryotic chromatin. However, unlike nucleosomes, no histones could be detected in the purified complexes. Rather, the complexes are generated by the interaction of nonhistone proteins with DNA. Ordered NPCs containing pFLBH (an adenovirus 2 major late promoter-containing plasmid) DNA were purified and concentrated by velocity sedimentation onto $62 \%(w / w)$ sucrose cushions and used directly as templates for RNA polymerase II in the Hela whole cell transcription extract. Transeription of these NPCs yielded an accurate and specific run-off RNA product as demonstrated by nuclease SI analysis and by denaturation with glyoxal followed by size analysis in 2 . agarose gels. Specific RNA synthesis is sensitive to a-amanitin ( $1 \mathrm{\mu g} / \mathrm{ml})$. The specific product can be obtained either by prior digestion of the NPCs with restriction enzyme or by restriction in situ.

We have also found that the reaction parameters for the transcription of NPCs are different from those of naked DNA. In general, the $8 a i t\left(\mathrm{MgCl}_{2}\right.$ and $\mathrm{KCl}$ ) dependence curves display broader optima with the NPC templates as compared to naked DNA. Similarly, the rather stringent extract/template rat 108 needed with naked DNA are alleviated with NPC templates, thereby 
elininating the need for tedious assays to establish the optimal conditions for each extract prepared. It appears that the use of NPC3 as templates leads to a more easily mageable assay systen.

Curzent cell-free transcription systems are notoriously template inefficient. There is a bulk DiA dependence that can of ten be satisfied by the use of a synthetic DAM like poly(dI-dC), thereby conserving the precious template. We find that without the use of poly(dI-dC) a concentration of over $5 \mathrm{\mu g} / \mathrm{ml}$ naked DWA is veeded, whereas with IPC teaplates about $1 \mathrm{\mu g} / \mathrm{ml}$ is suffictent to detect the specific RHA product. Thus, the use of IPL tempiates increases the template efficiency by about one order of agnitude and obviates the necessity of using poiy(dI-dC).

Our results indicate that the $\mathrm{NPC}$ represent authentic intermediates of eukaryotic transcription and suggest that their formation leads to an enrichment of protein conpontats that are required for specific yet efficlent transcription.

Isolation of HeLa Nuclear Matrix Froteins and their Binding to DNA. The muclear matrix is the residual nuclear structure obtained after removal of the nuclear mabrane and bulk chromatin with a ild nonionic deterg: $t$, high salt and nucleases. During the last few years, a number of Important funct!nns have been shown to occur in the muclear matrix, for exanple, DNA replication, transcription and processing of RHA and its transport, sterold horwone action, etc. Most of the evidence has cone from in vivo studies. Very few investigations have been reported on the blochemical properties of the matrix proteins that play regulatory and functional roles in the above processes. This is presumably because of the difficulty of isolating these proteins in their native state.

During the last year we have conducted studies to optinize the conditions for the isolation of Hela nuclear matrix at low temperatures $\left(0-4^{\circ} \mathrm{C}\right)$. We have found that pancreatic DNase I and Alu I, the restriction endonuclease, are effective in almost completely digesting the nuclear DNA within $60 \mathrm{~min}$ either at room temperature or $0^{\circ} \mathrm{C}$. However, the restriction endonuclease, Eco RI, used by several investigators in matrix isolation is very inefficient even at high concentrations and elther at room temperacure or $37^{\circ} \mathrm{C}$. Thus, the use of DNase I or Alu I has permitted us to conduct the 1solation at $0-4^{\circ} \mathrm{C}$.

Several detergents were tested for their efficlency in releasing protelns from the nucleat matrix as well as malntainf.ng blological activity of the released protelns (as measured by their DNA binding properties and function during in vitro transcription). We find that sodium dodecyl sulfate at low concentrations $(0.1-0.2 \%)$ and several zwiterionic detergents that are $\mathrm{N}-\mathrm{alkyl}$ (either long chain aliphatic or cholamidopropyl) Lerivatives of sulfobetsines are quite effective in releasing proteins from the nuclear matrix. Nonionic detergents like $N$ P 40 and Triton-X-100, although gentle, are Inefficient in releasing proteins from ti:e matrix. 
Incubation of the isolated proreins with SV40 DNA leads to the formation of ordered nucleoprotein conplexes, as revealed by gel filtration, electron ncroscopy and analysis by micrococcal nuclease digestion. The beaded structures are sensitive to proteases and phenol extraction. These structures resemble the ordered nucleoprotein complexes formed when template DAU is incubated with HeLa cell-free transcription extracts, as described in the previous section. These DWA binding proteins are being tested for their possible roles in transcription.

1. Sinha, S. N., Hellwig, R. J., Allison, D. P., Niyogi, S. K., Conversion of simian virus 40 DAA to ordered nucleoprotein structures by extracts that direct accurate initiation by eukaryotic RNA polywerase II. Nucleic Acids Ree. 10: 5533-5552; 1982.

STRUCTURAL ASPECTS OF DNA IN ITS REPLICATION AND REPAIR

$\begin{array}{ll}\text { S. Mttra } & \text { E. T. Snowl } \\ \text { B. C. Pal } 2 & \text { C. R. Wobbe } 1 \\ \text { R. S. Foote } 3 & \text { C. C. Morse } 1 \\ \text { R. C. Bates } & \text { C. E. Snyder } \\ \text { A. Bhattacharyya }{ }^{4} & \end{array}$

Toxic byproducts that interact with cellular macromolecules, including DNA, are among the health hazards associated with energy production and utilization. The alterations of DNA as a result of reaction with the genotoxic chemicals may manifest in permanent changes like mutation and cancer. The research objective of this laboratory is to investigate the structure of DNA, the mechanism of DNA replication and its regulation, and the mechanism and role of repair of the altered DNA in the expression of heritable changes. This research has two broad aims, namely investigation of (a) the regulation of DNA replication in mammals, using parvovirus DNA as a model system and (b) the role of DNA repair in mutagenesis and carcinogenesis induced by simple alkylating mutagens.

Structure of DNA of Parvoviruses. Mammalian nondefective parvoviruses contain linear single-stranded (SS) DNA genomes of about 5000 bases. The $3^{\prime}$ and $5^{\prime}$ termini are present as somewhat imperfect halrpins of about 115 and 190 nucleotides respectively that are not homologous to each other. The in vivo DNA repilcation involves synthesis of linear, double-stranded (repilcative form) DNA that either in a monomeric or oligomeric form serves as a precursor of progeny SS DNA, which 18 subsequently packaged into native virions. Parvoviruses provide a good model for studying regulation of mammalian DNA replication because they are absolutely dependent for replication on the S-phase and the replication machinery of the host cells. Varlous mechanisms proposed for the mode of viral DNA replication are based on Cavalier-Smith's model of hairpin transfer that involves the $3^{\prime}$ halrpins 
acting as primers for DHA synthesis without de novo initiation and then transfer of the hairpin to the conplementary strand by action of a sitespecific endonuclease.

It was shown that the intracellular RF has proteins covalentiy attached to the ternini. We have confirned the observation that both monomer and dimer RP DHAs have protelns attached at the 5' ternini. This was shown by (1) registance of RF DNA isolated from the infected cells but not synthesized in vitro to $\lambda$ exonuclease (specific for $5^{\prime}$ strand of duplex DNA), (2) sensitivity of both in vivo and in vitro RF to E. coli

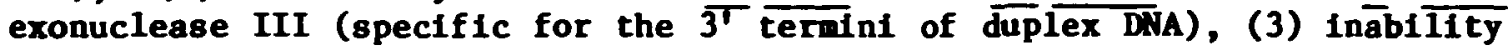
of the in vivo RP (but not in vitro RP) to migrate in agarose during electrophortsis in the absence of sodiun dodecyl sulfate, and (4) identical electrophoretic behavior of these RF DNAs after protease treatment. The presence of polypeptide covalently bound to in vivo RF was also shown by comigration of 355 rom methionine and 3 H-thywidine (used in labeling KRV-Infected NRK cells) during banding of DNA in CsCl and agarose gel electrophoresis ( $1 \mathrm{a}$ the presence of SDS). Atrempts to label the RF with 125I and subsequent analysis of the protein (after digestion of DNA) by polyacrylantde gel electrophoresis showed several autoradiographic bands inciuding $68 \mathrm{~K}$ and $40 \mathrm{~K}$ polypeptides. However, only the $40 \mathrm{~K}$ band appeared after digestion of DNA. Experiments are in progress to identify the 40K polypeptide, to estabilsh its cellular or viral origin, and to localize it on the DNA molecule.

Because the intracellular RF is present not only as monomers, but also as dimers and higher oligomers, we carried out pulse-chase experiments to establish the precursor of progeny viral DNA. This is an important point because various models have been proposed to explain the unique nucleotide sequence of the 3 terminuses but a "flip-flop" sequence of the 5 ' terminus of the viral SS DNA. These models invoke an oligomeric RF on the immediate precursor of progeny SS DNA. Our results strongly suggest that the dimeric RF is a dead end product of replication.

We are studying in collaboration with Dr. V. Ramakrishnan of Brookhaven National Laboratory, the architecture of the virion captid and the condensation of DNA in it by neutron scattering and electron microscopy. The empty capsids purifted from infected cells are unusually impermeable to uranyl acetate stain for electron microscopy, suggesting a very tight interaction between the protein subunits. Neutron scattering data are compatible with a 2-shell model for the capsid, where, apparently, the basic domain of the subunits may form the concentric inner shell and Intere:t with the core DNA.

$\mathrm{Q}^{6}$-Methylguanine-DNA Methy1transfer in Bacteria and Eukaryotic Cells. We reported a quantitative assay method for the $\underline{0}^{6}$-methylguanine-DNA methyltransferase that acts stoichlometrically by transferring a wethyl group to itself. We have worked out a new rapld assay for the enzyme based on this transfer of a methyl group. [ $\left.{ }^{3} \mathrm{H}\right]$ me:hyl labeled-DNA (containing $58 \%$ of total label in $0^{6}$-methylguanine) mined with 32 p-labeled UNA was incubated with $\underline{E}$. coli extract contalning the methyltransferase. Because 
the ${ }^{3}$-wethyl group was transferred to the enzyee, the reduction of the ratio ${ }_{\mathrm{H},}^{32} \mathrm{P}$ in the aqueous layer after extraction of the proteins with phenol is a measure of the wethyltransferase. Using this assay we purified the methyltransferase from a methyltransferase constitutive $E$. coli watant. The enzyne gave a single band after electrophoresis in SDS/polyacrylanide gel and has a molecular weight of 19,000 , as deternined by e.ectrophoretic nobility, filtration in Sephadex G-75 and eqillibriun centrifugation. This value is in agreement with that of Dempte et al. (J. Biol. Chen. 257: $13776,1982)$, published recently. The methyltransferase tends to aggregate in high mercaptoethanol. We are currently purifying the zethyltransferase from Bactllus subtilis in order to study the comparative properties of the enzyme from the two bacteria.

We extended our assay of the methyltransferase in different mamalian cell lines, and the results can be summarized as follows. (1) Hanster cell lines ( $\mathrm{CHO}, \mathrm{V79}$ and derivatives of V79) have no detectable nethyltransferase. Syrian hamster liver has about a third ( 3500 molecules/cell) as much activity as rat liver. This is in agreement with the published In vivo data and is significant in view of the fact that CHO and v79 cells are routinely used as test systems for mutagenicity assays. (2) Contrary to the observation of Haldstein et al. (Nucleic Acids Res. 10: 4595, 1982), the methyltransferase is not inducible in several human and rodent cell lines following treatment of the cells with repeated subtoxic doses of N-methyl-N'-nitro-N-nitrosoguanidine (MNNG). (3) The level of the methyltransferase does depend, to some extent, on the cell cycle, the highest level being observed in the late s-phase. Our results also do not agree with the published experiments of Waldstein et al. (Proc. Nat. Acad. Sci. USA, 79: 5117, 1982) in that we could not detect any wethyltransferise in several $0^{6}$-methylguanine repair-deficient (Mex ${ }^{-}$) cell lines, and de novo synthesis of the enzyme took nearly 40 hours rather than 6-12 hours in cells in which the preexisting enzyme was inactivated by exposure to MNG. Yarosh et al. (Mutat. Res., in press) have recently observed that some $\mathrm{Mex}^{-}$cei18 have an intermediate level of methyltransferase suggesting that Mex (Mer) may be a regulatory locus. Our attempts to induce the enzyme by treatment of cells with 5-azacytidine (to inhibit methylation of DNA, which is known to affect gene expression in mammalian cells) have, so far, been unsuccessful.

Base-palring Properties of $Q^{6}$-Methylguanine. It has been proposed on theoretical grounds that the $0^{6}$-wethylguanine $\left(m^{6} G\right)$-thymine pair should be nearly as normal as the $A \cdot T$ and $m^{6} G \cdot C$ pair should be unstable. On the other hand, earlier experiments suggested that $m^{6} G$ in the templata DNA may pair with $T$ about a third as frequently as with $C$. We investigated the base-pairing behavior of $0^{6} \mathrm{C}$ present both in the trmplate DNA and as a deoxynucleotide precursor during in vitro replication of synthetic DNA primer-template with purified $T 4$ and $\overline{T S}$ phage DNA polymerases and $\mathrm{E}$. coll DNA polymerase $I$. Our results on base pairing of $\mathrm{m}^{6} G$ in template DNA can be summarized as follows: (1) When poly $\left(d T, \mathrm{~m}^{6} \mathrm{dG}\right)$ or poly $\left(\mathrm{d} C, \mathrm{~m}^{6} \mathrm{dG}\right)$ containing covalently attached oligo(dA) or oligo(dG) as a primer was used as a template, $m^{6} G$ preferred pairing with $T$ sir to twenty times over that with $C$, depending on the polymerase. This is based on an apparent 
Michaelis constant (R $\mathrm{R}_{\mathrm{mPP}}^{\mathrm{a}}$ ) of dTTP and dCTP during DNA synthesis. T4 DNA polyeerase shows more discrinination towards the ${ }^{6} G \cdot T$ pair as compared wth the A.T pair than do the other two polyerases. The netal ion cofactor $\left(\mathrm{Mg}^{2+}\right.$ or $\mathrm{Mn}^{2+}$ ) affects the relative incorporation of $\mathrm{dTMP}$ and dCMP directed by $a^{6} G$. (2) $M^{6} G$ in the template also directs incorporation of dAMP although the $\mathrm{K}^{\mathrm{aPP}}$ for dATP is quite high. While dTPP and dCTP are competitive inhibitors of each other, dAMP Incorporation is not inhibited by dTTP. (3) The presence of ${ }^{6} G$ causes Inhibition of DNA synthesis. (4) The turnover of dTTP is higher with $\mathrm{m}^{6} \mathrm{G}$ in the template than that of dATP wich $d T$ in the tempiate. While these results support the theoretical prediction that the $m^{6} G \cdot T$ pair is much more favorable than the $m^{6} G^{\circ} \mathrm{C}$ pair, they also indicate that $m^{6} G \cdot T$ is hardly a normal $A \cdot T-11 k e$ pair, at least Insofar as the DNA polynerases are concerned.

It has recentiy been proposed that in vivo alkylation of deoxynucleotides in the DNA precursor pool, in addition to alkylation of DNA by alkylating wutagens, may be a major wutagenic event. Our results with incorporation of ${ }^{6}$ dGMP into both synthetic and natural DNA tenplates indicate that (1) dGMP pairs preferentially with $T$ in the template, (2) $m^{6}$ dGTP Inhibits DNA synthesis, apparently acting as a chain terminator, (3) T4 DNA polymerase is much less efficient than T5 DNA polywerase or E. coll DNA polymerase $I$ in accepting $m^{6} \mathrm{dGTP}$ as a subitrate. While in the absence of dATP $\mathrm{m}^{6} \mathrm{dGMP}$ cannot be incorporated (in the presence of dTTP) in the poly $(\mathrm{dA} \cdot \mathrm{dT})$ template by any DNA polymerase, the T4 enzyme, unlike T5 and the $E$. coll enzywe, cannot utilize $m^{6} \mathrm{dGTP}$ in the presence of a low concentration of dATP. The turnover of $m^{6} \mathrm{dGTP}$ is much higher with the T4 enzyme than with the other two enzymes. Based on the relative $k$ app of $m^{6} d G T P$ and $k_{1}^{a p p}$ and $k_{m}^{a p p}$ of dATP, it appears unlikely that $m^{6} d G T P ~ 18$ significantly incorporated in vivo to act as a promutagenic precursor. Finally, Stankowski and Hsie (this Division) attempted to incorporate ${ }^{6}$ dGTP in CHO cells. While the permegbilized cells did take up a significant amount of the nucleotide, no $\mathrm{m}^{6} \mathrm{G}$ was detected in the cellular DNA and no mutation was observed.

Synthesis of $Q^{4}$-Ethyl-dTTP and Incorporation of $Q^{4}$-Ethylthymidine in DNA. In addition to $0^{6}$-alkylguanine, $0^{4}$-alkylthymine, also produced in DNA by simple alkylating agents, is believed to be a promutagenic lesion as well. We have infitiated a program to study the repair and miscoding properties of $0^{4}$-ethylthymine $\left(e^{4} T\right)$ by utilizing an approach similar to that used for $\overline{0}^{6}$-methylguanine. We have synthesized both unlabeled and $\left[{ }^{3} \mathrm{H}-\mathrm{CH}_{3}\right] 0^{4}$-ethyl-dTTP. The unlabeled $\mathrm{e}^{4} \mathrm{dTTP}$ was synthesized by cthylation of thymidine, isolation of $\mathrm{e}^{4} \mathrm{dT}$, and then stepwise conversion of the deoxynycleoside to the corresponding triphosphate. For synthests of the labeled $e^{4} d T P$, we started with 5-hydroxymethyldeoxyuridine. After synthesis and purification of $0^{4}$-echyl-5-hydroxymethyl dUTP we have reduced the triphosphate with ${ }^{3} \mathrm{H}_{2}$ in the presence of $\mathrm{Pt}$. $\mathrm{0}^{4}$-ethyl-dTTP has been used as a substrate for calf thymus deoxynucleotidyi terminal transferase for the synthes1s of poly $\left(d T, e^{4} d T\right)$, whtch was then annealed with poly $(d A)$ to produce duplex DNA and containing $e^{4} T$ as the only modified base. We are at present studying the mechanism of repair of the alkylated base. 
1. Banerjee, P. T., 0lson, H. H., Allison, D. P., Bates, R. C., C. E. Snyder, Mitra, S., Electron mcroscopic comparison of the sequencer of single-stranded genones of mamalian parvoviruses by heteroduplex sapping. J. Hol. B1ol. 166: 257-272, 1983.

2. Bates, R. C., Snyder, C. E., Banerjee, P. T., Mitra, S., Autonomous parvovirus LuIII encapsidates equa] anounts of plus and uinus DNA strands. J. Virology, in press.

3. Burd, P. R., Mitra, S., Bates, R. C., Snyder, C. E., Thompson, L. D., Stout, E. R., Restriction enzyne analysis of the bovine parvovirus genone. J. Gen. Virol., in press.

4. Dodson, L. A., Foote, R. S., Mtra, S., Masker, H. E., Mutagenesis of bacteriophage $T 7$ in vitro by incorporation of $0^{6}$-methylguanine during DNA synthes 1s. Proc. Nat1. Acad. Sc1. USA 79: 7440-7444, 1982.

5. Foote, R. S., Pal, B. C., Hitra, S., Quantitation of $0^{6}$-methylguanineDNA methyltransferase in HeLa cel1s. Mutat. Res. 119: 221-228, 1983.

6. Foote, R. S., Mitra, S., Lack of induction of $0^{6}$-methylguanine-DNA methyltransferase in mammalian cells treated with $\mathrm{N}$-methyl-N ${ }^{1}-n i t r o-$ N-nitrosoguanidine. Carcinogenesis, in press.

7. Hadden, C. T., Foote, R. S., Mitra, S., Adaptive response of Bacillus subtilis to N-methyl-N'nitro-n-nitrosoguanidine. J. Bacterion. 153: $\overline{756-762,1983 .}$

8. Mitra, S., Pal, B. C., Foote, R. S., $0^{6}$-methylguanine-DNA methyltransferase in wild type and ada mutants of Escherichia coli. J. Bacteriol. 152: 534-537, 1982.

9. Mitra, S., Snow, E. T., Bhattacharyya, A., Dodson, L. A., Masker, W., Pal, B. C., Poote, R. S., Mutagenic properties of O-alkylated bases in DNA in vivo and in vitro. Proceedings XV Internat. Cong. Genetics, in press.

10. Pegg, A. E., Welst, L., Poote, R. S., Mitra, S., Perry, W., Purification and properties of $0^{6}$-methylguanine-DNA transmethylase from rat liver. J. Biol. Chem. 258: 2327-2333, 1983.

11. Snow, E. T., Foote, R. S., Mitra, S., Replication and repalr of $0^{6}$-methylguanine in DNA. Prog. Nucleic Acids Res. Mol. Biol. 29: 99-103, 1982.

12. Snyder, C. E., Schmoyer, R. L., Bates, R. C., Mtra, S., Callbration of denaturing agarose gels for molecular weight estimation of DNA: Size determination of the single-stranded genomes of parvoviruses. Electrophores18 3: 210-213, 1982.

13. Yarosh, D. B., Poote, R. S., Mitra, S., Day, R. S. III., Repair of $0^{6}$-methylguanine in DNA by demethylation is lacking in mer human tumor cell strains. Carcinogenesis 4: 199-205, 1983.

14. Yarosh, D. B., Rice, M., Poote, R. S., Mitra, S., Day, R. S. III., $\mathrm{Mer}^{-}$human tumor cells lack $0^{6}$-methylguanine-DNA methyltransferase. Mutat. Res., In press. 
PSTOCESSING OF RNA IN YEAST

Audrey Stevens

Following transcription of RNA molecules, these molecules undergo unique processing reactions to yield the final active RNA species. tRNA molecules are trimmed at both ends and intervening sequences are removed by cleavage and ligation reactions. The same is true of rRNA molecules. mRNA molecules are capped, polyadenylated, and intervening sequences removed in reactions which are still largely uncharacterized. Each mRNA molecule turns over in both the nucleus and the cytoplasm in order to preserve 1ts optimal cytoplasmic concentration in the cell. Since cell survival is dependent on most of these many RNA molecules, any environmental agent that interferes with the reactions described may be deleterious. Studies of enzymes involved in RNA processing reactions continue in this laboratory.

A unique exoribonucleise of yeast which produces 5'-mononucleotides by a $5^{\prime}+3^{\prime}$ mode of hydrolysis has been investigated further in order to discern the possible function and also the potential use of the enzyme. It has been suggested that the exoribor.uclease may have an important function In the cell in the degradation or turnover of mRNA after removal of the 5 ' cap structure by a decappling enzyme which is found closely associated with the enzyme. It 18 also possible that the enzyme could serve as a tool in the 18olation of cappe] RNA species if their hydrolysis rate 18 considerably less than that of uncapped specles such as rRNA. A study of the hydrolysis of mRNA has been carried out using cap-labeled mRNA, $\left[{ }^{3} \mathrm{H}\right] \mathrm{m}^{7} \mathrm{Gppp}-$ $[14 \mathrm{C}] \mathrm{RNA}-\mathrm{poly}(\mathrm{A})$, and the rate of hydrolysis compared with that of rRNA. Products $\left(\left[{ }^{3} \mathrm{H}\right] \mathrm{m}^{7} \mathrm{G}\right.$ and $\left.\left[{ }^{3} \mathrm{H}\right] \mathrm{m}^{7} \mathrm{GpppN}\right)$ of the cleavage of the cap-labeled RNA have been separated by paper electrophoresis. The results show that the phosphodiester bonds of the cap atructure and the terminal phosphodiester bond of the capped RNA are degraded at less than $10 \%$ (about $4 \%$ ) of the rate of rRNA. Other studies show that all uncapped RNA species are hydrolyzed at very similar rates. The results suggest that the enzyme could play a role in vivo in mRNA turnover with the cap structure providing unique protection and could be important as an in vitro tool in the 1solation of capped RNA spectes.

Studies of a yeast endoribonuclease which 18 found in the same protein fractions as the exoribonuclease have continued. The hydrolysis of yeast poly(A)-containing RNA by the enzyme 18 inhibited by ethidium brotide and proflavin, which intercalate in double-stranded structures. At low enzyme concentrations, the hydrolysis is stimulated several-fold by small nuclear RNAs UI and U2 of Novikoff hepatoma cells. The stimulation appears to Involve an Interaction of the small nuclear RNA with the poly(A)-containing RNA. The enzyme does not cleave the synthet1c polyribonucleotides-poly(U), poly(C), or poly(A). It does not cleave tRNA and hydrolyzes rRNA at about $25 \%$ of the rate of poly(A)-containing RNA. The specificity of cleavage of the poly(A)-contalning RNA has been determined by degrading the products with alkall, venom phosphodiesterase and $P_{1}$ nuclease, and by phosphorylating the products with $\left[\gamma^{32} \mathrm{P}\right]-\mathrm{ATP}$ and polynucleotide kinase. The enzyme 
shows a unique preferential cleavage (>90\%) of UpA or CpA bonds. In 507 of the scissions, the nucleotide linked to the $A$ is $G$. The products of the cleavage are U>p or $C>p$-terminated oligonucleotides complexed with the enzyme. The nature of the complex is under investigation. The cleavage specificity of the enzyme suggests that it may play a rol? in a key processing reaction. It is possible that it may function in an endonucleolytic inactivation of mRNA (in prokaryotes, the turnover of mRNA is precipitated by an endonucleolytic cleavage) or in splicing of pre-mRNA (UAG or CAG is part of the consensus sequence at the $3^{\prime}$ splice junction of all introns).

1. Stevens, A., Determination of the rate of hydrolysis of cap-labelled mRNA by a $5^{\prime} \rightarrow 3^{\prime}$ exoribonuclease of yeast. Blochem. Blophys. Acta, in press.

\section{MODIFICATION OF STRUCTURES AND FUNCTIONS OF PROTEINS INVOLVED IN PHAGE T5 DNA REPLICATION}

$$
\text { R. K. Fujimura B. C. Roop }
$$

Background. Phage T5 DNA is a linear duplex DNA with a molecular weight of about $7.7 \times 10^{7}$ and corsisting of more than 100 genes. In vivo analysis suggests that it is capable of initiating DNA replication from several sites with a primary site around a midregion of DNA. Thus we believe that the replication system is intermediate in complexity between that of small circular DNA and eukaryotic chromosomal DNA. It 18 our objective to characterize every process involved in DNA replication, particularly infitation, translocation, unwinding, and fidelity. We wish further to study effects of mutagenesis of genes, products of which are involved fin these replication processes.

So far, two gene products coded by the phage T5 DNA are known to be absolutely essential for DNA replication. These are the DNA polymerase coded by gene D7-D9 and the DNA binding protein coded by gene D5 (gPD5). Both of these ace routinely isolated to homogeneity in our laboratory. There are several other phage gene products known that affect the onset, rate, and duration of DNA replization. Our studies suggest that some host proteins are also involved.

Our work on the characterization of the T5 DNA polymerase has shown that T5 DNA polymerase 18 a monoricic, multifunctional enzyme. Its most preferred primer template is single-stranded DNA with a primer. It preferentially binds to such DNA at a $3^{\prime}-\mathrm{OH}$ primer end rather than at an end of a template strand or a single-stranded region. However, it does bind to a nick of duplex DNA and utilizes a $3^{\prime}-\mathrm{OH}$ end of a nlck as a primer and elongates it from such an end, displacing the strand ahead of it. With a 
nicked circular duplex DNA the replication may continue until the copied segment is longer than the circunference of the initial circle. It is a highly processive enzyne. By our technique it was processive to the end of poly(dA) used as a template which was about 400 nucleotides long. It has a $3^{\prime}+5^{\prime}$ exonuclease associated with it, which also acts processively. We have shown that a single enzyse bound at a priner :and can function as an exonuclease or as a polywerase depending on nucleoside triphosphates. It may reverse the direction in the wdst of hydrolysis and start polymerization. Thus, the same polywerase is capable of acting as an editing enzyme, correcting nistakes as it copies a template. By controlling this property of the enzyme one may be able to control base analogue incorporation at a specific region thus producing mitation at a specific site.

Gene product D5 has a dual role in DNA replication and control of transcription. It is essential for shutoff of some early transcriptions and for the expression of late genes. It is an asymmetric protein of molecular weight 28,000 . There are about 500,000 coples per cell, making it the most abundant DNA-binding protein synthesized in TS phage-infected ce11s. It binds to both double- and single-strinded DNA, but with higher affinity and cooperativity to double-stranded DNA. Thus it differs from bacteriophage $\mathrm{T} 4 \mathrm{gp} 32$ and Escherichia coli single-strand-binding protein, which are known as helix-destabilizing proteins; these bind preferentially and cooperatively to single-stranded DNA.

The role of gpD5 in DNA replication 1s not clear. When nicked DNA 1s complexed to saturation with $8 \mathrm{PD} 5$, both DNA polymerase and $3^{\prime} \rightarrow 5^{\prime}$ exonuclear activities are inhibited. Thus this protein may be used in control of fidelity of DNA replication in vitro.

\section{Experiments in Progress:}

a. Interaction of gpD5 with duplex DNA and 1 ts effect on DNA polymerase functions. Interactions of duplex DNA with gpDS were characterized by velocity sedimentation of the complex to apparent equilibrium in a metrizamide gradient $(1,3)$. The studies showed that duplex DNA saturated with gPD5 has a buoyant density of $1.17 \mathrm{~g} / \mathrm{cm}^{3}$. The binding of $\mathrm{gpD} 5$ to duplex DNA is cooperative In a buffer of low lonic strength, but apparently noncooperative in the presence of $10 \mathrm{mM} \mathrm{MgCl}_{2}$. Calculations based on these data showed that at saturation 40 base pairs are covered per gpDS molecule. When nicked DNA was complexed with T5 DNA polymerase and then complexed with gPD5 to saturation, both the polymerase and 1 ts associated $3^{\prime} \rightarrow 5^{\prime}$ exonuclease activities were Inhibited (2). E. coll exo III was also inhlbited. These findings suggested that enzymes that require properly H-bonded $3^{\prime}$ OH ends of DNA are Inhibited by gPD5 complexed to the duplex region. Purther kinetic studies of the polymerase inhibition suggested that the translocation process of DNA polymerase along a template 1s Inhibited. The cooperativity of the binding of gpD5 may be directly correlated to Inhibition of DNA synthesis. For quantitative determination of cooperativity, better techniques are being developed. One possibility 
is direct measurement of cluster size by electron microscopy. This is under Investigation in collaboration with David Allison.

b. Correlation of structure and function of T5 DNA polymerase. According to genetic analysis, the structural gene for T5 DNA polymerase is located at loci D7-D9 of the " $D$ " segment of T5 DNA. (On the basis of recombination frequencico sanng various conditional lethal witants of phage T5, T5 DNA is made up of four "segments;" D Is the largest and occuples the region from the middle to the right parc of T5 DNA, consisting of genes that are transcribed from the early to the late period of infection.) There 18 no vigorous work correlating gene loci to physical loci on DNA, However, by transfection of $\underline{E}$. coll with restriction enzyes digests that were fractionated according to size and by use of such transfected cells as hosts for "marker rescue" experiments with amber wutants of the TS DNA polymerase gene, we were able to identify the DNA fragment with the T5 DNA polywerase gene. With recent improvement in the sensitivity of marker rescue experiments we are about to identify a minimal DNA egment with the gene. We have isolated DNA fragments containing a fraction of the gene, and it is being cloned. Meanwhile we have learned to purify large quantities of the restriction fragments of T5 DNA. These were used to isolate some ts mutants of TS DNA polymerase. We are planning to isolate more, and we hope that these mutants will consist of T5 DNA polymerase with altere:d properties on fidelity of replication, processiveness of translocation along the template and strand displacement. Essential structural properties of the polymerase for these processes will be studied.

Future Goals. Our objective is to learn to modify specific regions of the polywerase by site directed wutagenesis of 1 ts gene or by direct modification of functional domains of the enzyme. By these means we hope to make polymerase that is more efficient as replicative polymerase, as repalr polymerase, or as mutator polymerase. We may be able to make conditional mutator polymerase that will alter genes cloned into a variety of vectors with different requirements. Such a mutator polymerase may be used to study effects of agents associated with energy technologies.

1. Fujimura, R. K., Roop, B. C., Interaction of a DNA-binding protein, the gene product of $D 5$ of bacteriophage $T 5$, with double-stranded DNA. J. Biol. Chem. 257: 14811-14815, 1982.

2. Pujimura, R. K., Roop, B. C., Interaction of a DNA-binding protein, the product of gene $D 5$ of bacterlophage $T 5$, with double-stranded DNA: Effects on T5 DNA polymerase functions in vitro. J. V1rol. 46: $778-787,1983$.

3. Roop, B. C., Das, S. K., Rujimura, R. K., Purification of the product of gene D5 coded by bacterlophage T5. J. B10l. Chem. 257: 14816, 1982. 
NUCLEIC ACID BIOCHEMISTRY OF CELLS

\author{
Elllot Volikin H. H. Jones \\ K. E. Boling
}

On. of the major prograns of the Biology Division is directed toward determining the mechanisus by which a variety of energy-related products may cause pathological conditions (mutations, cancer, toxicity, etc). Our particular approach has been to investigate the effect of these agents on the mucleotide pools - the proximal precursors in the synthesis of DNA and RNA.

We have shown that nucleotide biosynthesis in Novikoff hepatoma and CHO cells is markedly altered by a variety of chemical witagens (N-methyl$N^{\prime}$-nitro-N-nitrosoguanidine, 4-nitroquinoline 2-oxide, 9-aninoacridine, and mitomycin $C$ ). Concentrations of these compounds that cause some inhibition of RNA and DNA synthesis bring about a large increase in the pool levels of all four nucleoside triphosphates. At the sane tine, the blosynthetic pathways leading to the synthesis of CTP from exogenous uridine and GTP and ATP from exogenous hypoxanthine are severely inhibited. The mutagens cause similar inhibitions in the de novo purine and p:'rimidine nucleotide synthesis routes, as demonstrated with experiments witr. labeled formate and aspartate. Thus, a widely divergent reduction in th.e labeling of RNA-CMP versus RNA-UMP and of RNA-GMP versus RNA-AMP is created, mostly a result of these agents causing large differences in the specific activities of the respective triphosphate precursors. These observations suggest that, in addition to the reactions with DNA, nucleotide biosynthesis is another important biochemical target of chemical mutagens.

More recent experiments using an excess of deoxyribonucleosides such as thymidine in the growth medium show that these compounds not only alter DNA synthesis, but also have a profound effect on the ribonucleotide pool and RNA synthesis itself. Taken together, these experiments reinforce the hypothesis Invoked by many laboratories that severe Imbalance of nucleotide pools, particularly as brought about by mutagenic agents, may be a major cause of mutations and/or toxicity.

1. Rannels, D. E., Low, R. B., Youdale, T., Volkin, E., Longmore, W. J., Use of radiolsotopes in quant'sative studies of lung metabolism. Fed. Proc. 41: 2833-2839, 1982.

2. Volkin, E., Bolling, M. B., Lee, H. H., Jones, M. H., The effect of chemical mutagens on purine and pyrimidine nucleotide biosynthesis. Bloch1m. Blophys. Acta 755: 217-224, 1983. 
CHROMOSOHE CHEMISTRY
D. E. 01 ins $^{3}$
A. L. $011 \mathrm{~ns}^{3}$
A. E. Roberson 1
T. J. Laughlin ${ }^{3}$
A. L. Herraann ${ }^{3}$
R. L. Allen 1
C. $Y$ Horton ${ }^{3}$
C. L. Cadillal
J. M. Harp ${ }^{3}$
J. H. Finch ${ }^{3}$

The jor goal of this laboratory is to analyze and understand the macromolecular structure of eukaryotic chromosomes. This macromolecular structure is intimately involved in the three major functions of chromo8ones: DNA packaging, transcription, and replication. Any of these functions can be damaged by exposure to abnoraal physical or chenical agents. Our laboratory employs a wide range of biophysical, biochemical and ultrastructural techniques to work towards detailed macromolecular models. During the past year our laboratory has concentrated its efforts in two najor directions: (1) chronatin structure in the hypotrichous cillated protozoa, and (2) 3-D reconstruction of a transcriptionally-active gene by electron nicroscope tomography (BMT).

1. Chromatin Structure in the Hypotrichous Ciliated Protozoa. All cillated protozoa exhibit nuclear dualism, i.e, the existence of transcriptionally-active macronuclei in the same cytoplasm with inactive micronuclei. The hypotrichous clliated protozoa possess two distinct nuclear features that distinguish them from other ciliates: (1) macroniclei consist of a "bag" of high polyploid (ca. $10^{4}$ fold), short (ca. 2-3 kbp), linear DNA molecules of low sequence complexity - each fragment probably corresponding to an individual structural gene and its regulating flanking sequences; and (2) macronuclear DNA replication is localized exclusively in a Replication Band (RB) that migrates along the nucleus during $S$ phase. Both of these features are unique in biology and offer considerable advantage compared to typical eukaryotic nuclei. In order to capitalize upon these advantages we have spent considerable time with the following projects: (1) large-scale cultivation and harvesting of protozoa, especially Oxytricha and Euplotes; (2) 1 ysis of cells and isolation of macronuclei, with minimum rucleolytic and proteolytic degradation; (3) preparation of macronuclear DNA fragments, gel electrophoresis and blot-hybridization with specific gene probes; (4) preparation of soluble chromatin, with characterization of nucleosome repeat lengths and companion blophysical parameters (i.e., thermal stability and circular dichrolc spectra); (5) analysis of various nuclear histones and non-histones; (6) development of unique cytochemical reactions for the Replication b d (7) isolation and characterization of the chromatin properties of RB; $a_{1}$ ' (8) ultrastructural analysis of the patterns of replicating DNA in the RB. Current experiments are focusing upon: (1) the subfractionation of Euplotes macronuclear chromatin into transcriptionally-active and inactive species, and (2) the development of specific immunochemical probes for replicational machinery coinponents.

2. Three-dimensional Reconstruction by EMT. We have deve oped a method for defining the 3-D ultrastructure of sectloned and stained 
chromosomal preparations. This method does not require internal regularities or a lattice arrangement of identical structures. It is strictly analogous to tonography. The resulting reconstiscted images can be viewed as 2-D slices or built into solid models by stacking balsa wood slices. Employing EMT, we have completed 3-D reconstructions from a number of chromosomal structures. Most attention has been focused upon a chromosomal region of RNA synthesie, the Balbiani Rings of Chironomus salivary gland cells. This gene is present on highly polytcne chromosones (ca. $10^{4}$ endoreplicated), and when active generates a "puffed" region in the chromosome body. In the electron microscope, electron-dense nascent ribonucleoprotein granules (RNP) can be observed surrounding the chromatin axis. Using BMT, we have analyzed the 3-D arrangement in situ of these RNP around the chrowatin, as well as the patterns of folding the nascent RNP. We are currently pursuing EMT on a number of other chromosomal structures including the $25 \mathrm{~mm}$ higher-order arrangement of nucleosomes and the Replication Band of hypotrichous cillates. Furtherwore, we are developing a 3-D display viewer that would permit user-interactive manipulation, editing and model building of the reconstructed images.

1. Butler, A. P., Olins, D. E., pH effects on the structure of the 1nner histon.s. Bioch1m. Biophys. Acta. 698: 199-203, 1982.

2. Laughlin, T. J., Henry, J. M., Phares, E. F., Long, M. V., Olins, D. E., Methods for the large-scale cultivation of an Oxytricha. J. Protozool. 30: 63-64, 1983.

3. Olins, D. E., Olins, A. L., Levy, H. A., Durfee, R. C., Margle, S. M., Tinnel, E. P., Dover, S. D., Electron microscope tomography: Transcription in three dimensions. Science 220: 498-500, 1983.

4. Uberbacher, E. C., Mardian, J. K. W., Ross1, R. M., Olins, D. E., Bunick, G. J., Neutron scattering studies and modeling of high mobility group 14 core nucleosome complex. Proc. Nat1. Acad. Sci. USA 79: 5258-5262, 1982 .

\section{NUCLEOSOME AND CHROMATIN BIOPHYSICS}
G. J. Bunick 5
E. C. Uberbacher ${ }^{4}$
B. E. Hingerty ${ }^{6}$

The major goal of this laboratory 18 to analyze and understand the structure and function of the key macromolecular components of genetic material. The macromolecular components under investigation are involved in the major functions of chromatin: DNA packaging, regulation and transcription, and replication. It is our intent to def ine the role these macromolecules play in facilitating these processes and how exposure to mutagenic or carcinogenic environmental agents may affect necessary genetic functions. Our approach 18 to use a number of blophysical and blochemical techniques to provide detalled structural models of these 1mportant 
macromolecules. ie have concentrated our effort in three ajor directions: (1) X-ray crystallograpty of avian erythrocyte mononucleosomes; (2) smallangle neutron scattering studies of mucleosomes, Hug-nucleosone conplexes, and mucleosone olfgomers; (3) wlecular wdeling and energy refinement of DKA-carcinogen adductio.

1. X-ray Crystallography of Nucleosomes. Two crystal forns of avian erythrocyte mucleosome core particles (i.e., 145 bp DMA and the hietone octaner) have been discovered in this laboratory. One is in the space group $P 21$ and contains tro nucleosones in the asymetric unit. Diffraction data have been collected on this forn to a resolution of $6.1 \mathrm{~A}$ and an 1somorphous heavy-aton derivative search is in progress. The second crystal fore, in space group C2, with one-half mucleosome per asyumetric unit has a sinflar diffraction quality.

Crystallographic structure deternination of the nucleosome will provide considerable new Information about DWA packaging and regulation. It w11 also allow detailed odeling of how carcinogentc agents are 11kely to affect mucleosome function and genetic expression. Experimental structure determinations of nucleosones which have been modified by carcinogenic agents also be possible in the future.

2. Dynamical Studies of the Nucleosone and the HMG-Nucleosone Complex. Transcription of chromatin necessarily requires conforuational changes at the level of the nucleosone. In a low lonic strength environment the nucleosome can be made to partially unfold and the DNA partially unwind. Saall-angle neutron scattering (SANS) has been used to elucidate the conformational details of this process and the results have provided important information as to the probable in vivo mechanism of nucleosone unfolding during transcription. Using these methods it way be possible to evaluate how chentcal agents affect normal conformational changes in the nucleosome.

HMG proteins are thought to play an important role in making regions of chromatin transcriptionally active. SANS has been used to evaluate the conformational effects of binding HMG 14 to mononucleosomes in a stoichiometric 2:1 complex. This study provided important insights as to how HEG 14 may stabilize an unfolded nucleosome. An additional study involving HMG i7 is planned.

Materials have been produced for intended scattering studies on nucleosomal dimers and longer oligomers. These materials represent good model systems for evaluating the dynanlc processes in the chromatin of higher animals.

3. Molecular Modeling and Energy Refinement of DNA-Carcinogen Adduct 8. The objective of this work 18 to determine the distortion imposed on DNA by the covalent linkage of polycyclic aromatic hydrocarbons and amines that are known environmental mutagens and carcinogens. It is 1ikely that the conformation of the carcinogen-DNA adducts will determine whether or not the damage is repalrable, or whether a mutation that can lead to 
cancer w11 ensue oil replication. This study should reveal unifying conforeational features that are characteristic of utagenic and carcinogenic adducts. Several such conpounds have been studied while bound to short Dil sequences which contain high reactivity loci. These studies have demonstrated inportant classes of DMA distortions. This investigation will be extended to include the interactions of such conpounds with mucleosonal DWI as structural details of the mucleosone becone available. This will allow evaluation of the effects that histones have on induced DNA distortions and potential carcinogenesis.

1. Harrington, R. E., Uberbacher, E. C., Bunick, G. J., Conforation of the HIG 14 mucleosome core conplex from flow birefrigence. Nucleic Acids Res. 10: 5695-5709, 1982.

2. Bingerty, B., Broyde, S., Conformation of the deoxydinucleotide mophosphate dCpdG odified at carbon 8 of guanine with 2-(Acetylanino) flourine. Blochemistry 21: 3243-3252, 1982.

3. Bingerty, B., Broyde, S., MF linked to the guanine anino group: a B-Z Junction. Hucleic Acids Res. 11 : 3241-3254, 1983.

4. Uberbacher, E. C., Mardian, J. K. W., Rossi, R. M., Olins, D. E., Bunick, G. J., Neutron scattering studies and wodeling of high mbility group 14 core nucleosome complex. Proc. Natl. Acad. Sc1. USA 79: $5258-5262,1982$.

5. Uberbacher, E. C., Ramakrisinan, V., Ollns, D. E., Bunick, G. J., Neutron scattering studies of nucleosones at low lonic strength. Blochenistry 22: 4916-4923, 1983.

\section{X-RAY DIFFRACTION}

c. H. WeI

One of the simplest $\mathrm{Pt}^{2+}$ complexes, c1s-diamminedichloroplatinum(II) (c1s-DDP), is known to be a clinically effective antitumor drug. The binding of cis-DDP to DNA by intercalation 18 presumably responsible for its selective cytotoxicity. The toxic mechanism of this compound 18 being Intensively studied. Molecular configurations of cls-DDP-like complexes involving nucleoside are therefore useful information in our understanding of structure-function relationships.

A compound of presumed formula $\mathrm{Pr}\left(\mathrm{AdO}^{\circ} \mathrm{Cl}_{2}\right)$ was prepared in 1978 by J. D. Hoeschele (Health and Safety Research Division) by the reaction of $\mathrm{K}_{2} \mathrm{PtCl}_{4}$ wth adenosine. Repeated attempts to crystallize the brownish powder product finally yielded yellow crystals from a mixed solution of pyridine and DySO. Useful untwinned crystals (I) were obtained from a solution of 1,2-dichloroethane. When complex I was further treated with pyridine and DMSO (volume rat1o 9:1) in the presence of a small amount of water over a steam bath, large colorless crystals were obtalned (II). 
Subsequent structural analyses by X-ray difíraction have shown complex I to be trans-dichloro(dipyridine)platinum(II) and complex II to be tetrapyridineplatinun(II) dichloride trihydrate. As expected, the $\mathrm{Pt}^{2+}$ ion possesses typical square-planar configuration in each case with $\mathrm{Pt}^{2+}$ coordinated to two $\mathrm{Cl}^{-}$and two $\mathrm{N}$ atoms of pyridine ligands in complex $\mathrm{I}$, and to four $N$ atons of pyridine molecules in complex II.

As part of our efforts to synthesize metal complexes with noleties of DHA, $\mathrm{K}_{2} \mathrm{PtCl}_{4}$ was reacted with guanosine some years ago. From the greenish anorphuus product greyish chunky crystals were grown from an aqueous solution. Prior to the $X$-ray investigation, it was thought that the crystals were those of a complex form of platinum and guanosine and therefore erited structural analysis. Results of the $X$-ray analysis, however, revealed that the crystal was that of bulbocapnine (an aporphine alkaloid) methiodide, structure of which had previously been determined by S. Basu and J. R. Einstein some five years ago (has not been published). Although the compound was not a platinum complex of guanosine, as anticipated, this example serves to demonstrate the powerfulness of the $X-$ ray characterization method in analyzing a solid compound to unravel its ultinate structure. The advantage of our determination over that of BasuEinstein is that wore data were collected by the use of Mo Ka radiation from a larger crystal, thereby the apparent high precision of the molecular parameters was made even more credible.

The structural investigations of the above-mentioned three compounds were accomplished in collaboration with B. E. Hingerty of the Health and Safety Research Division. The $X$-ray counter data were collected in the laboratory of G. M. Brown and W. R. Busing of the Chemistry Division.

1. Hardgrove Jr., G. L., Einsteln, J. R., Hingerty, B. E., Wel, C. H., The structure of adenine dinitrate, $\mathrm{C}_{5} \mathrm{H}_{7} \mathrm{~N}_{3}-2+\cdot 2 \mathrm{NO}_{3}$. Acta Cryst. C39: 88-90, 1983.

2. Hardgrove Jr., G. L., Elnsteln, J. R., We1, C. H., Structure of $\mathrm{p}-\left(\mathrm{p}-\mathrm{Nit}\right.$ roanilino) phenyl lsothlocyanate, $\mathrm{C}_{13} \mathrm{H}_{9} \mathrm{~N}_{3} \mathrm{O}_{2} \mathrm{~S}$. Acta Cryst. C39: 616-620, 1983.

3. Hel, C. H., Structure of 4-methyl-5-(2-pyraziny1)-3H-1,2-dithiole3-thlone (oltipraz), $\mathrm{C}_{8} \mathrm{H}_{6} \mathrm{~N}_{2} \mathrm{~S}_{3}$ : A new antischistosomal drug. Acta Cryst. C39: 1079-1082, 1983.

4. Hei, C. H., Crystallization of two cubic forms of soybean trypsin inhibitor E-I, a member of the Bowman-Birk inhibitor family. J. Biol. Chem. 258: 9357-9359, 1983.

5. Wei, C. H., Antischistosomal analogs of hycanthone. III. Structure of 1:1 chloroform solvate of 8-chloro-2-[2-(d1ethylamino)ethyl]-2H-[1]benzoth Lopyrano $\left[4,3,2\right.$-cd ] Indazole-5-methanol, $\quad\left[\mathrm{C}_{20} \mathrm{H}_{22} \mathrm{ClN}_{3} \mathrm{OS}\right]\left[\mathrm{CHCl}_{3}\right]$. Acta Cryst. C39: $1377-1382,1983$. 
6. Hei, C. H., Elnstein, J. R., Characterizations of the wohohydrates of the mosodiun and dipotassiun salts of cis-syn thymine photodimer. Crystallographic treatments of ixed crystals containing dimers and monomers resulting from $x$-ray cleavage of diners in the solid state. Acta Cryst. B40: in press.

THE STRUCTURE AND ORGANIZATION OF THE EUKARYOTIC GENOME

WITH SPECIAL gMPHASIS ON SATELLITE DNAS AND THE PHENOHENOLOGY AND CONTROL OF THE CRUSTACEAN MOLT CYCLE
Dorothy M. Skinner
Veta Bonnewe11 4
Richard F. Fowler ${ }^{3}$
Barbara Haas 3
Donald L. Mykles 4
Cynthia Soumof $\mathrm{f}^{4}$

We have cloned into three different restriction enzyme sites of pBR322 repeat units or subunits of a $G+C-r i c h(637 G+C)$ satellite that accounts for 37 of the genome of the Bermuda land crab, Gecarcinus lateralis. The satellite, which is very much more complex than any other satellite characterized to date with the exception of a minor component of very highly repeated DNA scattered throughout the genome of humans, has an average $2.07 \pm 0.1 \mathrm{~kb}$ repeat unit. A series of variants of the satellite contain transitions, transversions, amplifications, insertions and/or deletions from specific regions of as little as a few and as many as some hundreds of base pairs. The cloned variants of the satellite offer a unique opportunity to determine structure-function interactions.

We have sequenced three of the cloned satellite varlants. One variant 18 close to the average size of the repeat unit of the satellite (RU, $2.089 \mathrm{~kb}$ ); another 18 truncated (TRU, $1.639 \mathrm{~kb}$ ) by the presenr of an extra Eco RI site near 1ts 3 ' end; a third is extended (EXT, $2.639 \mathrm{~kb}$ ). EXT has a 142 base pair segment that has undergone a fivefold amplification to yield six tandem coples of the segment. The amplified sequence is bounded by a tetranucleotide inverted repeat; the upstream arm of the inverted repeat $18 \mathrm{missing}$ from the $\mathrm{RU}$ and TRU. The latter variants contaln only one copy of a sequence that is closely related to the amplified sequence. By contrast to the amplification seen here, in several satellite DNAs of other organisms, extra DNA is inserted. These three variants have been stable through multiple rounds of replication in HBI01 and therefore seem unlikely to have been derived from cloning accidents.

Comparisons among the sequences of the three variants are Informative. There are highly conserved domains (from 84 to $96 \%$ homology); these are interspersed with other domains of marked sequence divergence. The conserved domains can be as long as 594 bp; they contain "garden variety" DNA. The divergent domains contain repeated sequences, such as homopolymers [n $=7+23$ ] of $C_{n}$ or $G_{n}$ but not $A_{n}$ or $T_{n}$; or homocopolymers [n $=4+17$ ] of $(C C T)_{n},(C A)_{n},(A G G)_{n}$, or $(A G)_{n}$ but not $(A T)_{n}$. Other regions adjacent to major sequence variations are characterized by long 
stretches of alternating purines and pyrialdines (pu/py). That the latter adopt a $Z$ conformation appears likely, since at least one stretch of pu/py of complex sequences which should not permit strand slippage exhibits $S_{1}$ sensitivity. Thus, the satellite variants provide a nodel systen for the study of Z-DKA in naturally occurring sequences.

In contrast to the overall siallarity among restricticn maps of $\mathrm{RU}$, $E X T$, and TRU, $S_{1}$ cleavage patterns are quite distinctive. This lends strong support to our proposal that divergences in simple repeated sequences can markedly affect the secondary and tertiary structure of DNA nolecules with overall high honology.

Beyond the obvious homoco- and homopolymers, five tandem (CGCAC) 8 , and other variations on that pentaner, or the fivefold amplification in EXT, computer searches have failed to reveal any large blocks of simple repeating sequences and thefr variants. The complexity of some domains of this crab satellite appears to be real.

Given such complexity, is the satellite transcribed and translated? The three possible reading frames of the sequence of $\mathrm{RU}$ have been searched for initiation and termination codous.3. In the three reading frames on one strand, there are 6, 5, and 5 iuttiation codons and 9, 18, and 23 termination codons. The longest possible protein coded for in each frame is 163, 97, and 49 amino acids. A similar analysis, reading in from the $5^{\prime}$-end of the opposite strand, ylelds longest possible peptides of 84,77 , and 23 anino acids. The microheterogeneity of the satellite does not make transcription any the less likely, since mutations in the wobble base may yield such microheterogeneity without significantly altering the ultimate peptide readout.

Other research has been on:

a. Isolation of a $\mathrm{Ca}^{2+}$-dependent neutral proteinase. The claw closer muscle of Gecarcinus undergoes a sequential atrophy and restoration during each molt cycle. We have purified and characterized a $\mathrm{Ca}^{2+}$-dependent proteinase involved in the turnover of myofibrillar protein in normal anecdysial (intermolt) and atrophying proecdysial (premolt) claw muscle. Crab Ca${ }^{2+}$-dependent proteinase degrades the myofibrillar proteins actin, myosin heavy and light chains, paramyosin, tropomyosin, and troponin-T and $-I$. The enzyme is a sarcoplasmic cysteine proteinase that shows maximal activation at $1 \mathrm{mM} \mathrm{Ca} \mathrm{Ca}^{2+}$ at neutral $\mathrm{pH}$. Hydrolysis of $125 \mathrm{I}$-myosin occurs in two phases, both Ca ${ }^{2+}$-dependent. Large fragments produced in the first phase are hydrolyzed to acid-soluble material in the secund. Although radiolodinated native hemolymph protelns are not susceptible to the $\mathrm{Ca}^{2+}$-dependent protelnase, those denatired by carboxymethylation are degraded. These data suggest that crab $\mathrm{Ca}^{27}$-dependent proteinase 18 involved in turnover of myofibrillar protein in normal muscle and muscle undergoing proecdysial atrophy. 
b. Ecdysterold titers in blue crabs. While ecdysterold ifters in other crabs reach a peak just prior to ecdysis, those of the edible blue crab were clained to reach their maxima after ecdysis. Our recent data chailenge these findings. We have masured ecdysteroids in hemolymph, ovaries, and thole animal extracts of blue crabs using a RIA. In hemolymph and whole antaals, ecdysterold levels rose during proecdysis to a maximum at stage $D_{3}$. Ecdysteroids declined rapidly from late proecdysis through metecdysis, then increased slightly, and returned to low levels where they remained during anecdysis.

c. Partial characterization of a crustacean mono-oxygenase. We have partially characterized the enzyme in Gecarcinus that converts a-ecdysone to 20-hydroxyecdysone, the active form of the molting hormone. of the tissues examined, aidgut gland was most active in metabolizing a-ecdysone to 20-0H-ecdysone, which was the only metabolite. The enzyse is localized in a witochondria-enriched cell fraction, has $a K_{m}$ of $I$ it and a cemperature optimum of $30^{\circ} \mathrm{C}$, simflar to the mono-oxygenases in other arthropods. It is, however, exceptional in that it requires a high $\mathrm{pH}$ ( $\mathrm{pH} 8.3-8.8$ optinum) and does not have an absolute requirement for NADPH. The hydroxylase is fully active during anecdysis and proecdysis but not at the time of ecdysis. This finding indicates that the rise of 20-0H-ecdysone levels is not reflected in hydroxylase activity.

1. Bonnewe11, V. B., Fowler, R. F., Skinner, D. M., An inverted repeat borders a fivefold amplification in satellite DNA. Science 221: $862-865,1983$.

2. Mykles, D. L., Skinner, D. M., $\mathrm{Ca}^{2+}$-dependent proteolytic activity in crab claw wuscle. Effects of inhibitors and specificity for myofibrillar proteins. J. Biol. Chem. 258: 10474-10480, 1983.

3. Mykles, D. L., Skfnner, D. M., Muscle atrophy and restoration during molting, in Wenner, A. M. (ed.): Crustacean Growth, Balkema Press II, In press.

4. Skinner, D. M., Bonnewell, V. B., Fowler, R. F., Sites of divergences in the sequence of a complex satellite DNA and several cloned variants. Cold Spring Harbor Symposium 47: 1151-1157, 1982.

5. Skinner, D. M., Fowler, R. F., Bonnewe11, V., Domains of simple sequences or alternating purines and pyrimidines are sites of divergences in a complex satel11te DNA, in Cozzare111, N. R. (ed.): Mechanisms of DNA Replication and Recombination, ICN-UCLA Symp. Mol. Cell. Biol., Vol. 10, in press.

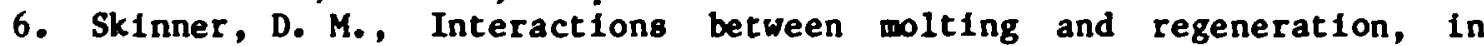
Bliss, D. E., Mantel, L. H. (eds.): The Blology of Crustacea, Acadenic Press, in press.

7. Skinner, D. M., Graham, D. R., Holland, C. A., Mykles, D. L., Soumoff, C., Yamaoka, L. A., Control of Crustacean molting, in Wenner, A. M. (ed.): Crustacean Gruwth, Balkema Press II, in press. 
8. Skinner, D. M., Grahan, C. A., Holland, C., Soumoff, C., Yamaoka, L. H., Hykles, D. L., Regulation of crustacean molting and regeneration. Proceedings IXth International Congress of Comparative Endocrinology, Hong Kong, University Press, In press.

9. Soumoff, C., Skinner, D. M., Ecdysteroid titers during the molt cycle of the blue crab resemble those of other Crustacea. B1ol. Bull. 165: 321-329, 1983.

ENZYME AND GENE REGULATION: NORMAL MECHANISMS AND RESPONSES TO TOXIC METAL IONS
K. Bruce Jacobson
J. Flanaganl
E. B. Wright
J. Ferre

The blological consequences of exposure of humans to elevated levels of substances that normally are encountered in trace amounts wust be understood. In my research program the mutational and toxicologicd consequences have been selected for those studies and two strategies are followed: (1) determine how the effects of certaln mutations are neutralized by a natural mechanism; this is termed suppression and (2) seek the earliest events that occur when an animal is exposed to toxic metal Ions and relate those to the physical-chemical properties of the metal ion.

Suppression. When the suppressor mutant su(s) ${ }^{2}$ of Drosophila melanogaster is present, the effects of four mutations (vermilion, purple, speck, and sable) are alleviated. This suppressor has been known for decades but the mechanism by which the four mutations are reversed is poorly understood. The goal of our study is to determine the molecular mechanism by which the purple mutant is restored to normal by su(s) ${ }^{2}$. A closely related goal is to determine the defects in pteridine biosynthesis caused by the purple mutant that mist be alleviated.

During the past year our studies have shown that (1) the defective step for the purple mutant involves the synthesis of ramiopterin, (2) ramlopterin 18 an unusual pteridine whose properties are simflar to those of 5,6-dihydropteridine, (3) ramlopterin loses one or wore hydrogens on conversion to a closely related metabolite called $x_{1},(4) x_{1}$ would be an appropriate precursor for 6-acetylpyrimidodiazepine whose structure we established recently, (5) 6-acetylpyrimidodiazepine has the ability to replace riboflavin for the growth of Lactobactllus case1, and (6) 6-acetylpyrimidodiazepine 18 quite similar to a chromophore that is isolated from tumerous lymphoid cells. Also we found that an 1mproved procedure for 1solation of GTP cyclohydro:..se was possible thus making a contribution to the technique in ti.e study of pteridine blosynthesis. ine of our Immediate goals is to study ramiopterin synthase and we have devised a convenient assay procedure for the assay of this enzyme activity. At this time progress continues in unraveling steps in pteridine biosynthesis and we are better prepared to study ramiopterin synthase. 
In previous studies a role of tRNATyr had been suggested in the mechanism of suppression by $\mathrm{su}(s)^{2}$. At that time we predicted a difference In the minor base composition between normal and su(s) ${ }^{2}$ tRNA $^{\text {Tyr }}$. Recently we isolated these tRNAs from the usual laboratory strains of normal and su(s) ${ }^{2}$ Drosophila and demonstrated two minor base changes. However, we also constructed two strains of Drosophila su(s) ${ }^{+}$and $s u(s)^{2}$, that are genetically Identical except ror the $\langle 1 \%$ of their genome that accompanies the su(s) locus. These tRNATyr were isolated and found not to have a difference in base composition. This is not consistent with our earlier hypothesis regarding the involvement of $t R N A^{T y r}$ in the mecilanism of suppression. Henceforth we plan to turn our attention elsewhere in the study of $\mathrm{su(s)^{2 }}$.

Toxic Mechanisms. The physical chemical properties of metal lons have been measured in many ways, but our primary goal is to determine which of these many parameters are most relevant to the blological damage metal lons cause. A related goal is to ascertain the earliest macromolecular alterations that occur after toxic metal ion is taken up by an organism. This project is an outgrowth of a seed money project and has become an interdivisional activity with two physicists (J. E. Turner and M. W. Williams, Health and Safety Research Division).

Earlier studies had identified cadmium as the most toxic divaleat ion for Drosophila melanogaster. Using ${ }^{109} \mathrm{Cd}$ the rate of uptake and release of $\mathrm{Cd}^{2+}$ was measured for two strains of Drosophila that are most resistant and most sensitive to this wetal lon. No difference between the strains was found for the rate of cadmium uptake but they do differ in the rate of excretion. The more resistant strain retained the cadmium for markedly longer times than the sensitive strain; we had predicted the opposite behavior. This indicated that the resistant strajn could immobilize the cadmium so we looked for a cadmium-binding-substance that could chelate the toxi a ion. Indeed such a substance does appear when flles are fed cadmium chloride and the levels in the resistant strain exceed those in the sensitive strain. Currently we are preparing to 1solate and characterize this naturally occurring, inducible chelator of cadmium. The mechanism by which this organism can complex and immobilize toxic metal lons may be of general application and help explain how resistance is achieved.

To explore the effects of metal lons on nucleic acids the study of $\mathrm{Zn}^{2+}$ on transfer RNA is continuing. To facilitate the use of physical chemical techniques we now use highly purifled tRNA Phe of yeast. As in previous chromatographic studies with other tRNAs, tRNA Phe adsorbs to the RPC-5 column more strongly in the presence of $\mathrm{Zn}^{2+}$ and in proportion to the concentration of $\mathrm{Zn}^{2+}$. Nelther $\mathrm{Mg}^{2+}$ nor $\mathrm{Cd}^{2+}$ cause this effect. Detalled studies on the effects of $\mathrm{Zn}^{2+}$ showed that isochratic elution as well as gradient elution gave simflar results and that the effect of $2 \mathrm{n}^{2+}$ could be countered by $\mathrm{Cd}^{2+}$ or $\mathrm{Mg}^{2+}$; the former is much more effective, surprisingly. High resolution nuclear magnetic resonance spectra allow each hydrogenbonded base palr and base triple to be observed. $\mathrm{Zn}^{2+}, \mathrm{Cd}^{2+}$ and $\mathrm{Mg}^{2+}$ each causes alterations in this secondary and tertiary structure; again $\mathrm{Cd}^{2+}$ and $\mathrm{Mg}^{2+}$ exhibit effects that are simtlar to each other and different from 
:hose caused by $\mathrm{Zn}^{2+}$. These new studies are incomplete but very promising. Using small angle neutron scattering we are starting to evaluate the

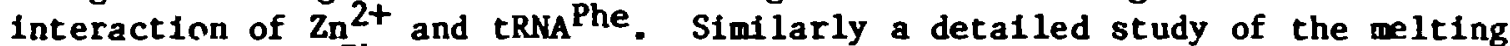
behavior of $t$ NNA $^{\text {Phe }}$ is being intiated to evaluate how metal ions perturb the tRNA structure. The studies on tRNA are interesting in themselves and may also be considered model studies that would find application in evaluating the effects of metal ions on DNA and other RNAs.

1. Birchler, J. A., Owenby, R. K., Jacobson, K. B., Dosage compensation of serine-4 transfer RNA In Drosoph1la. Genetics 102: 525-537, 1982.

2. Christie, N. T., Owenby, R. K., Jacobson, K. B., Hfatt, V. S., Farkas, W. R., Queuine-containing isoacceptor of tyrosine tRNA in Drosophila melanogaster. Alteration of levels by divalent cations. Biochim. Biophys. Acta 699: 40-48, 1982.

3. Hear1, W. G., Jacobson, K. B., Eye pigment granules of Drosophila melanogaster: Isolation and chracterization for synthesis of sepiapterin and precursor of drosopterins. Insect Blochem., in press.

4. Hearl, W. G., Dorsett, D., Jacobson, K. B., The comon precursor of sepiapterin and drosopterin in Drosophila: Enzymatic and chemical synthesis, in Wood, H. S. C. (Eu.): Pteridine and Folic Acid Derivatives, Amsterdam, Elsevier/North Holland, In press.

5. Jacobson, K. B., Dorset t, D., Pfleiderer, W., McCloskey, J. A., Sethi, S. K., Buchanan, M. V., Rubin, I. B., A naturally occurring pyrimidodiazepine in Drosophila: Chemlcal and spectral froperties and relationship to drosopterin. Biochemistry 21: 5700-5706, 1982.

6. Jacobson, K. B., Turner, J. E., Christie, N. T., Owenby, R. K., Toxic and biochemical effects of divalent metal lons in Drosophila: Correlation to effects in mice and to chemlcal softness parameters, Sci. Total Environ. 28: 355-366, 1983.

7. Jacobson, K. B., Yim, J. J., Grell, E. H., Wobbe, C. R. Mechanism of suppression in Drosophila: Evidence for a macromolecule produced by the $8 \cdot 1(8)^{+}$locus that inhibits sepiapterin synthase. Cell 30: $817-8 \overline{23,1982 .}$

8. Jacobson, K. B., Yim, J. J., Wobbe, C. R., Macromolecular regulation of seplapterin and drosopterin synthesis in the purple mutant of Drosophila, in Wood, H. S. C. (ed.): Pteridines and Follc Acid Derivatives, vol. 5, Amsterdam, Elsevier/North Holland, In press.

9. Turner, J. E., Lee, E. H., Jacobson, K. B., Christie, N. T., Williams, M. W., Hoeschele, J. D., Investigation of correlations between chemical parameters of metal lons and acute toxicity in mice and Drosophila. Sci. Total Environ. 28: 343-354, 1983. 


\section{DNA DOSIMETRY APPLIED TO PROBLEMS IN GENETIC TOXICOLOGY}

$$
\text { R. 0. Rahn Helen Sellin }
$$

Our mor goals are to devise methods for quantifying low levels of DNA damage, to analyze the chemical nature of DNA base damage, and to understand the mecinanisms by which chemical and physical agents cause DNA damage. There is a need to understand the relationship between genetic damage and blological response, i.e., how much of a given type of damage contributes to the possibility of a cell being transformed. There is also a need to know what normal background livels are for a given form of damage. Finally, there is a need to know how much damage to DNA results when a cell is exposed to a given insult from the environment. Studies have been conducted using UV, metal lons, and polyaromatic hydrocrabons as DNA damaging agents. The UV studies have focussed recently on the substitution of halogenated bases in DNA as a means cf introducing a specific type of photo damage into the DNA. The metal ion studies have centered on platinum binding to DNA because of its role in treating cancer and because of the availability at Oak kidge of the radioisotope $195 \mathrm{Pt}$. Finally, studies have been done to quantify very low levels of binding to DNA of benzo(a)pyrene, a chemlcal carcinogen, which 18 produced in the synthesis of synthetic fuels.

A method has been devised for removing Pt-base adducts from DNA and for separating these adducts chromatographically. This method has been applied to DNA 1solated from tissue culture cells treated with cisplatin. The resulls indicate that a significant ( $35 \%)$ portion of the cisplatin binds in a form which is the same as that found in DNA treated in vitro. This adduct consists of two guanine molecules connected by a platinum atom. It remains to be determined how the rest of the platinum binds in vivo, but one likelihood could be a crosslink with protein. The significance of our results at present 18 that a methodology now exists for examining the binding under in vivo conditions. From such information a bettir understanding of how cisplatin functions as an antitumor agent can be derived. In turn, more efficlent means of using antitumor agents can be obtained.

A very useful tool in photobiological research has been the substitution of BrdUrd for Thd in DNA. Following radiation, debromination and damage to the sugar phosphate backbone results. Also urac1l is formed. However, the actual chemlcal event responsible for the observed enhanced cell kflling is not krown. Neither single 8 trand chain breaks nor uracil formation is considered important. Our attempts to answer this question have employed the use of IdUrd Instead of BrdUrd, because of certain spectroscopic and chemical advantages. The information gained with IdUrd should apply to Brdurd. Current research deals with the mechanisms by which the uracil radical formed upon dehalogenation reacts with 1ts environment to p1ck up a hydrogen atom and form urac11. There are many interesting questions one can ask and a great deal of relevance to research conducted by others involving the reaction of allyl radicals in aqueous med1a. Considerable information has also been gathered concerning the 
origin and fate of the lodide and/or iodine atoms formed upon photolysis. From such information we can understand the mechanism by which the Hoechst dye 33258 can sensitize dehalogenation of DNA using $350 \mathrm{~nm}$ radiation. In particular, is there an electron ejection mechanism involved resulting in lodide but not lodine release.

Progress on the refinement of our fluorescent-HPLC assay for detecting benzo(a)pyrene binaing to DNA has not proceeded as quickly as one would like because of the funding cutback. In fact, little progress has been made In adapting the laser on hand ( $\mathrm{Cd} \cdot \mathrm{He}, \lambda_{\text {ex }}=325 \mathrm{~nm}$ ) to this purpose. After three moves, the equipment is finally located in a place where experiments can be run, and 1 it is expected that in the near future data will start being collected.

1. Rahn, R. 0., Chang, S. S., Hoeschele, J. D., Adducts formed between deoxyguanosine and cis-dichlorodiamineplatinum(II): separation by means of cation-exchange chromatography. J. Inorg. Biochem. i8: 279-290, 1983.

2. Rahn, R. 0., Chang, S. S., Holland, J. M., Shugart, L. R., A fluorometric-HPLC assay for quantitating the binding of benzola]pyrene metabolites to DNA. Blochem. Blophys. Res. Comm. 109: 262-268, 1982.

3. Rahn, R. 0., Sellin, H. G., Chain breakage accompanying the photolysis of IdUrd-DNA. Photochem. Photob1ol. 37: 661-664, 1983.

4. Shugart, Lee, Holland, J. M., Rahn, R. 0., Dosimetry of PAil skin carcinogenesis: covalent binding of benzolalpyrene to mouse epidermal DNA. Carcinogenes1s 4: 195-198, 1983.

\section{RESPIRATION SHUTOFF IN ESCHERICHIA COLI APTER FAR-UV IRRADIATION}

Paul A. Swenson
I. L. Norton

Damage to DNA of Escherichia coll by UV, lonizing radiation and chemicals causes a number of responses that require the recA ${ }^{+}$and lexA ${ }^{+}$ gene products. The responses include error prone repair (as Indicated by mutagenesis), filamentation and induction of prophage lambda. We study another important rec/lex response, shutoff of respiration, which occurs $60 \mathrm{~min}$ after exposuse to UV. Our objective 18 to understand the genetic and blochemical bases of the shutoff process and 1 ts control.

Most of our work on UV induced shutoff of respiration has been done with Escherichia coli $\mathrm{B} / \mathrm{r}$ and Salmonella typhimurium strains. Work was not previously done with $\mathrm{E}$. coli $\overline{\mathrm{K} 12}$ strains because the shutoff response was not seen by us and by others. Kl2 strains are more resistant to UV killing than $B / \mathrm{r}$ and we cound that at higher UV fluences $\left(125 \mathrm{~J} / \mathrm{m}^{2}\right.$ vB $52 \mathrm{~J} / \mathrm{m}^{2}$ for $B / r$ ) a good shutoff response was obtained. The UV Irduced response in E. coll K12 strains $W 3110$ and $A B 1157$ is ellminated in both strains by 5 
fluorouracil as in $E$. cull $B / r$. On the other hand, the response was anplified by cAMP in $\bar{W} 31 \overline{10}$ but not in ABI157. Mitomycin $C$ treatment caused respiration shutoff in both strains.

One of the advantages of being able to study UV induced respiration shutoff in $E$. coll $K 12$ strain $A B 1157$ is that there is a wealth of witant strains avaîlable. As expected, the recA and lexA derivatives of this strain did not show UV inducible shutoff of respiration. Two other rec mutants $F$ and $J$ did shut their respiration of $f$; both are deficient in DNA repair and recombination functions. Both umuC and uvrD wutants showed normal UV induced respiration shutoff responses. The unuC gene ${ }^{+}$ required for mutagenesis and umuc wutants are only slightly $\overline{U V}$ sensitive; the uvrD ${ }^{+}$gene codes for a DNA helicase and the wutant is UV sensitive.

No rec/lex responses to UV damage to DNA have been reported to be affected in recB or recC mutants. We found, however, that UV induced respiration did not take place in them. The recB ${ }^{+}$and recc ${ }^{+}$genes each code for a subunit of exonuclease $V$ which degrades DNA In Irradiated cells. recB and recC mutant strains are UV sensitive and show about 9971088 of recombination ability.

The sbcA and sbcB mutant genes each suppress the radiation sensitivity and recombination deficiency effects in a recB recC wutant strain but they do not affect the lack of ability to shut of respiration in this strain. The 8 bc ${ }^{+}$gene controls the production of exonuclease VIII and the 8 bcB ${ }^{+}$ gene codes for exonuclease $I$. The sbcA and sbcB mutants each have normal UV sensitivity and showed normal uv induced shutoff of respiration. The recB recC sbcA and recB recC sbcB strains are the only strains known to us that show normal UV sensitivity to killing but which do not show the respiration shutoff response.

Craham Walker and Cynthia Kenyon of the Massachusetts Institute of Technology have isolated a group of din mutants of $E$. coll K12. These DNA damaged inducible mutations were formed by transducting a lact gene via $\mu$ phage into promoter control regions of E. coll. They selected for transduccants that formed $\beta$-galactosidase when their DNA was damaged by $U$ radiations. We tested $s i x$ of these din mutants for their ability to shu: off their resplration after UV irradiation. Pour of them showed a normal respiration shutoff response, but two of them did not shut of their respiration. It is possible that one of these two strains contains a mutation in a gene which controls UV inducible respiration shutoff.

1. Swenson, P. A., Rtester, L., Palmer, T. V., Role of the supX gene in sensitizing Salmonalla typhimurium cells to respiration shutoff induced by far ultraviolet irradiation. Photochem. Photobiol. 38: $305-310,1983$. 


\title{
REGULATION OF TRANSPORT SYSTEMS IN CULTURED MAMALIAN CELLS
}

\author{
J. S. Cook \\ J. B. Fishman l \\ C. J. Shaffer \\ E. R. Weiss 1
}

Cells and whole organisas interact with their environment through their mbranes, plasma memanes for cells and cellular epithelial membranes for the organisa. As a protective masure, the lipid bilayer of the surface menrane of cells serves as an effective barrier to most of the polar compounds that may be dissolved in the aqueous environment in which cells live. As a corollary, the dissolved substrates required by cells or organisms either for maintenance or for growth are comonly taken up by specific transport systems. The latter, in turn, are well regulated in teras of numbers of transporters, the affinities of the transporters, or their degree of coupling to metabolic systens. Wur group has been studying various aspects of transport regulation in mamalian cells in relation to the metabolic requirements of the cells or, in model epithelial systems, the requirements of the organisa. Special emphasis is given to changes in these systems in response to growth stimuli and during epithellal differentiation. Our principal findings are:

Blosynthesis and Turnover of Na, $\mathrm{K}$-ATPase. This membrane-bound transport enzyme is the fundamental agent in regulating the salt content of cell;. It plays a major role in controlling other transport systems to whirh it is coupled as well as in the maintenance of the cell membrane pote'tial, cell volume, and an appropriate lonic milieu for the activity of cellular enzymes. This essential transport enzyme is itself maintained at appropriate levels and in a state of repair by constant turnover and replacement of the surface protein. The regulation of turnover is to some degree specific: in normal growth conditions $\mathrm{Na}, \mathrm{K}$-ATPase turns over 6-10 times faster than the bulk of membrane proteins. When the cells are $K-$ starved its turnover 18 reduced with no change in the blosynthetic rate; this results in a compensatory increase in surface activity.

The enzyme is composed of a catalytic subunit $\left(M_{r}=94,000\right)$ and a glycosylated subunit $\left(M_{r}=45-50,000\right)$ of unknown function. other laboratories working on the blogenesis of the enzyme have suggested that the catalytic subunit is synthesized on free cytosolic ribosomes while the glycosylated subunit 18 synthesized on ribosomes bound to the endoplasmic reticulum. In rat tumor cells, HTC, we find no evidence for free catalytic subunit; it is always associated with a membrane compartment. With an antibody method we can decect the onset of 1 ts synthesis 2 min after the addition of tracer. Over the next $5 \mathrm{hr}$ it moves through a series of membrane compartments until it enters a compartment that includes, but may not be exclusively composed of, the cell surface. Turnover takes place from this compartment at a rate of one set of surface molecules per half generation.

Recycling of Cell Surface Sialoglycoprotelns. We reported last year that after the general labeling of HeLa cell surface slaloglycoproteins they could be observed to exchange with an internal pool twice the size of 
the cell surface. From this pool the glycoproteins were removed slowly $\left(t_{1 / 2}=100 \mathrm{hr}\right)$ and degraded in turnover. By fractionation studies we have followed the pathway for the internalization side of recycling. The surface material moves into endosomes and is transferred into the lysosonal compartment. Most of the label is not degraded in the lysosones but is further transferred into the Gulgi compartment. This step is blocked if the acidification of the endosomes and lysosomes is inhibited with chloroquine or $\mathrm{NH}_{4} \mathrm{Cl}$. The label in the Golgi finally accumulates in a compartment distinct from either lysosomes or Golgi but with the properties of GERL (Golgi-endoplasmie reticulum-lysosome complex). Presumably most of the recycling back to the surface takes place from this complex, although some membrane in the easlier steps on the pathway may clrcumvent the later steps and return directly to the surface. Analysis of the proteins at each point shows that a few of them do not recycle but are iegraded after the first internalization. The sorting appears to occur at the endosome/ lysosome step. This dynamic behavior of the surface has profound implications for the conceptual view of what constitutes the cell surface and how its activities are regulated.

Differentiation of the Concentrative Hexose Transporter In Vitro in Cultured Kidney Cells, LLC-PK 1 . This transport enzyme is the expression of a highly differentiated function of the renal proximal tubule, and is the transporter responsible for the reabsorption of filtered glucose from the urine. In cultured pig kidney cells $L L C-P_{1}$, which we have re-cloned, the activity is not observable during the growth phase of the cells, but develops slowly (days) after confluence. By radioautographic methods we have demonstrated that the cells require $72 \mathrm{hr}$ in $G_{0}$ to develop the function. The methods are being refined to determine the kinetics on a cell-by-cell basis.

1. Amsler, K., Shaffer, C., Cook, J. S., Growth-dependent AIB and meAIB uptake in LLC-PK 1 cells: Effects of differentiation inducers and of TRA. J. Cell. Physiol. 114: 184-190, 1983.

2. Karin, N. J., Cook, J. S., Regulation of Na,K-ATPase by its biosynthesis and turnover, in Forbush, B., Hof fman, J. F., Forbush, B. (eds.): Current Topics in Membranes and Transport, vol. 19, New York, Academlc Press, in press.

THEORETICAL AND APPLIED CRYOBIOLOGY

$$
\begin{array}{ll}
\text { P. Mazur } & \text { U. Schneider } \\
\text { K. W. Cole } &
\end{array}
$$

The purpose of the Theoretical and Applied Cryoblology program is to determine the responses of cells to the major cryobiological variables involved in freezing and thawing such as cooling rate, and to the physical 
state of the cell and its surroundings. Besides freezing studies per se, our research involves a conbination of experi rental and athematical approaches to deternine the permeability and osiotic responses of cells to critical solutes and water. The cells current; under study are wouse and cattle embryos and human erythrocytes.

The progran is related to DOE's energy missions in the following way: First, animals and their tissues are used to assess bealth effects of effluents. Freezing can belp insure that the assay systens remain invariant with tiwe. It can also reduce the "noise" from genetic heterogeneity by allowing the storage of many tissue samples from a single donor. Second, freezing pernits the storage of animal and plant germplase in an unchanged state. The ability to freeze mmallan enbryos (first reported by this laboratory) is proving important to basic and applied geneticists. It is proriding the former with an econonical weans of preserving wtant strains of alce. It can help the latter accelerate the development of breeding strains of livestock that are wo energy efficient, or strains that can adapt to the altered clinatic conditions that ight attend the massive use of fossil fuels. Third, environnental insults are less serious if their effects can be reversed by medical therapy. There are a number of nedical applications to cryobiology especially in the transplantation of cells, tissues, and organs.

Research during the last year emphasized two najor problems. The first concerns the mechanisa of slow freezing injury. The second concerns the osmotic response of embryos to the cryoprotectants glycerol and DMSO.

Mechar.18ms of Slow Freezing Injury. As aqueous solutions freeze, the electrolytes in the external solution progressively concentrate, and if cooling is slow, the cells undergo progressive osmotic dehydration. It has been thought that slow freezing injury is the result of either excessive salt concentration or excessive cell shrinkage. But we have found recently that the survival of human red cells 18 predominantly affected by the size of the unfrozen channels in the solution or, more precisely, by the fraction of solution that remains unfrozen at any temperature. The phase rule dictates that solute concentration and fraction unfrozen are reciprocally related and ordinarily inseparable. One can separate them, however, by freezing celis in ternary solutions of nonelectrolyte, electrolyte, and water which differ in total solute concentration but maintain a fixed ratio of nonelectrolyte to electrolyte. We have performed these experiments with human red cells in solutions of glycerol-NaCl-water. Samples were frozen to various subzero temperatures which were chosen to produce various molalities of $\mathrm{NaCl}(0.24$ to 3.30$)$ while holding the fraction unfrozen constant, or conversely to produce various fractions unfrozen ( 0.03 to 0.5$)$ while holding the molallty of salt constant. Damage became extensive when more than $90 \%$ of the solution became frozen regardless of whether the salt concentration in that unfrozen fraction was as low as 1 molal or as high as 2.4 molal.

Investigators have reported, and we have confirmed this past year, that the hemolysis of red cells frozen to given subzero temperatures rises 
sharply wen the cell hematocrit is above 40z. Thinking that this rise aight be a consequence of effects of cell concentration on the unfrozen fraction, we have repeated the experiments referred to above with red cell hematocrits of $2 z, 8 z, 40 z$, and 60z. At henatocrits of $40 z$ and $60 z$, the cells thenselves occupy a considerable percentage of the unfrozen portion of the suspension. Or put differently, at the higher henatocrits the fraction of the suspension that renains unfrozen at a given temperature is considerably sealler than the fraction of the solution that realns unfrozen. When we plot survival vs the fraction of the suspension that remains unfrozen, wost of the effects of hematocrit disappear.

If these findings 0 the significance of unf rozen fraction tirn out to be applicable to cells other than erythrocytes, they wil require najor odifications in how cryobiologists view slow-freezing injury and its prevention. They ay be especially pertinent to the freezing of whole organs, since cells in organs generally occupy 507 or wore of the avallable space.

As a first step in deternining their generality, we are studying the survival of nouse embryos as a function of unfrozen fraction and the concentration of salt in that unfrozen fraction. To date sone 3300 mouse zygotes have been subjected to subzero temperatures pzoducing a range of unfrozen fractions and a range of concentrations of $\mathrm{NaCl}$ in that unfrozen fraction. Also included in the study are various weight percent ratios of salt to glycerol. Definitive conclusions wll have to awatt our completing the development of conputer prograns to analyze the data but it appears tentatively that the results are simflar to those for red cells.

Osmometry of House and Bovine Embryos and Their Perneability to Glycerol and DMSO. Embryos like wost cells require the presence and perweation of cryoprotectants like glycerol and DiSo to survive freezing and thawing. However, the abrupt addition of these additives causes transient osmotic shrinkage, and their abrupt removal by dilution produces considerabie osmotic swelling. If one knows the -olerated limits of shrinking and swelling, If In that range the embryos behave like ideal osmometers (1.e., plots of cell vol. vs 1/oswolality are linear), and if one knows the perweability coefficient of the additive, one can design optimum procedures for the addition and removal of the arditives using sets of permeability equations developed several years ago in this laboratory. This past year we have been obtaining the necessary information for nouse and bovine embryos. We find that wouse and bovine blastocysts behave like Ideal osmometers over hypo- and hyper osmolalities varying fron 0.08 to 1.7. They survive $30-$ nin exposure at $23^{\circ} \mathrm{C}$ over a range of 0.1 to 1.1 osmolal, but are damaged outside that range.

We have also determined the permeability coefficients of day-7 bovine blastocysts to DASO and glycerol by an indirect method involving measirements of the volume changes of embryos from serial photographs as a function of time in the cryoprotectant. Then curves of relative volume vs time were plotted and compared with curves generated by the computer for several permeability coefficients to determine which coefficient ylelded 
the best fit, At $23^{\circ} \mathrm{C}$ the permeability coefficient is estinated to be $1.5-1.810^{-3} \mathrm{ca} / \mathrm{ain}$ for DiSo and $2-2.510^{-3} \mathrm{~cm} /$ ain for glycerol.

1. Frin, J., Mazur, P., Interactions of cooling rate, warning rate, glycerol concentration, and dilution procedure on the viability of frozen-thawed human granulocytes. Cryobiology, in press.

2. Mazur, P., Rfgopoulos, N., Contributions of unfrozen fraction and of salt concentration to the survival of slowly frozen human erythrocytes: Influence of waraing rate. Cryobiology 20: 274-289, 1983.

3. Rall, W. P., Mazur, P, McGrath, J. J., Depression of the Icenucleation temperature of rapidly cooled wouse embryos by glycerol and dicethyl sulfoxide. Biophysical J. 41: 1-12, 1983.

4. Schneider, U., Mazur, P., Implications and applications of the longtere preservation of embryos by freezing, in Morrow, D. (ed.): Current Therapy in Therlogenology II, Philadelphia, W. B. Saunders, accepted for publication.

\title{
PROTEIN CHEMISTRY AND ENZYME MECHANISMS
}

\author{
Fred C. Hartman Eva Lee 4 \\ Mark I. Donneliy ${ }^{4}$ Claude D. Stringer \\ Cinda S. Herndon 1
}

Since virtually all biological processes are enzyme mediated, studies of enzywe structure and function are clearly central to a broad-based progran concerning health effects of environmental agents. Our efforts are focused on active-site characterization which bears directly on the elucidation of the principles underlying two key properties of enzymes: their stringent specificity and their enormous catalytic efficiency. The most versatile approach for the selective introduction of a chemical latsi Into the active site, thereby providing structure/function correlations and Identifications of active-sice residues, is affinity labeling. In its traditional form, affinity labeling entalls the use of reactive analogs of natural substrates to label substrate binding sites. Conceptually, it can be viewed as combining features of conpetitive inhibitors and gereral protein reagents into a single molecule. The substrate-lfke features of the reagent direct it to the active site in a fashion completely analogous to the binding of competitive inhibitors. This binding step results in a highly localized concentration of reagent within the substrate binding site and thus increases the likelihood of modification of a residue within this site as compared with other positions of the protein molecule.

Many of our recent Invectigations have centered on ribulosebisphosphate carboxylase, the plant enzyme essential for the photosynthetic assimilation of $\mathrm{CO}_{2}$. This enzyme also pos esses inherent oxygenase 
activity which accounts for photorespiration, a nonessential, energywasteful process that reduces net $\mathrm{CO}_{2}$ fixation. There is general agreement that preferential abolishment of the oxygenase activity would elevate by 507 the ylelds of 63 plants (plants in which ribulosebisphosphate 18 the Initial acceptor of atmospheric $\mathrm{CO}_{2}$ in contrast to $\mathrm{C4}$ plants in which phosphoenolpyruvate 18 the initial acceptor). Thus, an understanding of the in vivo modulation of the carboxylase/oxygenase ratio and a deteraination of whether this ratio can be systematically manipulated by external means are of ajor significance to agriculture and production of blonass.

In the absence of $\mathrm{CO}_{2}$ and $\mathrm{Mg}^{2+}$, ribulosebisphosphate carboxylase is devold of both catalytic activities. The activation process entalls the reaction of $\mathrm{CO}_{2}$ wth a specific lysyl e-anino group to form a carbanate which requires $\mathrm{kg}^{2+}$ for stabilization. Activator $\mathrm{CO}_{2}$ is distinct fcon substrate $\mathrm{CO}_{2}$; hence, characterization of the activator site as well as the catalgtic site are pertinent. to elucidation of mechanise of action and wode of regulation. During the past year, wave made substantial progress in mapping both sites.

The activation process for the enzyme from the purple, nonsulfur photosynthetic bacteriun Rhodospirillum rubrun has been carefully examined by chemical and physical methods. Stabilization of the carbamate by esterification with diazomethane permitted the isolation of a chymotryptic peptide containing the lysyl residue that 18 reactive toward $\mathrm{CO}_{2}$. Considerable sequence homology is seen between this region and the corresponding one in the spinach enzyme:

R. rubrum peptide

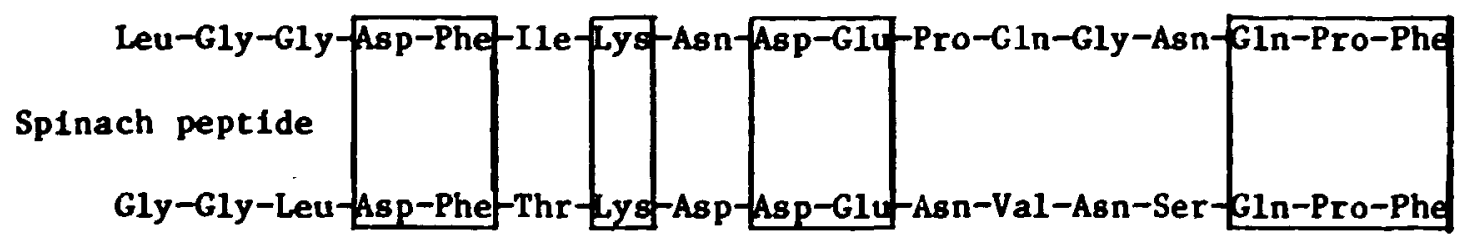

In collaboration with V. Ramakrishnan of tile National Center for Small Angle Scattering Research at ORN, we have compared the conformations in solution of deactivated and activated ribulosebisphosphate carboxylase (both spinach and $R$. Fubrum enzymes) by use of neutron scattering. We did not detect any major conformationgl change accompanying the activation process despite a suggestion in the literature to the contrary. With the spinach enzyme, the scattering data closely fit that expected for a hollow sphere with an outer radius of $56.4 \mathrm{~A}$ and inner radius of $14.3 \mathrm{~A}$. Th1s model agrees nicely with that determined by X-ray crystallography for the deactivated tobacco enzyme.

With respect to the catalytic site, we have designed a series of pocential affintty labels in which a chemically reactive side-chain is placed at the ponition corresponding to C2 of ribulosebisphosphate. The rationale for this series of compounds 18 twofold: 1) to probe that 
portion of the active site where substrate $\mathrm{CO}_{2}$ binds and 2) to attempt to map the distance between the catalytic and regulatory sites. One of these new reagents, 2(4-bromoacetamido)anilino-2-deoxypentitol 1,5-bisphosphate, fulfills all experimental criteria for affinity labeling and permits the identification of His-44 as an active-site residue in the $\underline{R}$. rubrum enzyme.

We have virtually completed the deternination of the complete primary structure of the carboxylase from $R$. rubrum. This project was undertaken because this organisa 18 one of the more primitive that contains the photosynthetic apparatus and also its carboxylase is a diner of identical subunits whereas the corresponding enzyme from higher plants and most other photosynthetic bacteria consists of eight pairs of nonidentical subunits. Hence, because of evolutionary diversity and gross differences in quarternary structure: we felt that comparisons of primary structure between the $R$. rubrun and higher plant enzyme would be very revealing with respect to regions required for function. This has indeed been the case. Although the total sequence howology is $<30 \%$, every residue that we have inplicated at the active site with affinity labels (Lys-175, Lys-334, and His-44) is located Wthin a segment of striking sequence invariance. Purtherwore, because of lack of conservation of any cysteinyl residues, we were able to dispel the long-standing notion that sulfhydryls are required for catalysis.

1. Alber, T., Hartman, R. C., Petsko, G. A., Crystal structure of yeast triose phosphate lsomerase: I. Conformation of the free enzyme at 3.0 A resolution. J. Mol. Biol., in press.

2. Cook, C. M., Tolbert, N. E., Hartman, F. C., The isolation of an active site peptide from spinach ribulose bisphosphate carboxylase/ oxygenase modified by glyoxylate, in Proceedings of the 6th International Photcsynthesis Congress, in press.

3. Donnelly, M. I., Stringer, C. D., Hartman, F. C., Characterization of the activator site of Rhodospirillum rubrum ribulosebisphosphate carboxylase/oxygenase. Biochemistry 22: 4346-4352.

4. Donnelly, M. I., Hartman, F. C., Ramakrishnan, V., The shape of ribulosebisphosphate carboxylase/oxygenase in solution as inferred from small angle neutron scattering. J. Biol. Chem., in press.

5. Donnelly, M. I., Ramakrishnan, V., Hartman, F. C., Chemical and physical characterization of the activation of ribulosebisphosphate carboxylase/oxygenase, in Proceedings of the 6th International Photosynthesis Congress, in press.

6. Fraij, B., Hartman, F. C., Isolation and sequencing of an active-site peptide from Rhodospirillum rubrum ribulosebisphosphate carboxylasel oxygenase after affinity labeling with 2-[(bromoacety1)amino] pentitol 1,5-bisphosphate. Blochemistry 22: 1515-1520, 1983.

7. Hartman, F. C., Stringer, C. D., Omnaas, J., Donnelly, M. .., Fra1j, B., Purification and sequencing of cyanogen bromlde fragwents from ribulosebisphosphate carboxylase/oxygenase from Rhodospirillum rubrum. Arch. B1ochem. B1ophy 8. 219: 422-437, 1982. 
8. Herndon, C. S., Hartman, F. C., 2-(4-Browoacetamido)anilino-2deorypentitol 1,5-bisphuspiate, a wej áfinity label for ribulosebisphosphate carboxylase/oxygenase fron Rhodospirillue rubrue. Deteralnation of reaction parameters and characterization of an active-site peptide. J. Biol. Cher., in press.

9. Schloss, J. V., Phares, E. F., Long, M. V., Norton, I. L., Stringer, C. D., Hartman, F. C., Ribulosebisphosphace carboxylase/oxygenuse from Rhodospirillue rubrue, in Hood. H. A. (ed.): Methods in Enzymology, Vol. 90, Acadenic Press, New York. 1982, pp. 522-528. 


\title{
Comparative Genetics Section
}

\author{
SECTION OVERVIEW - J. L. EPLER
}

The Comparative Genetics Section contains a diversity of research but has the common goal of providing information relevant to the estimation of the genetic hazards of radiation and chemicals to man, especially as these biohazards are encountered in energy-related processes. Our strategy is to expand our understanding of the mechanisms of mutagenesis and to deveiup and valldate a variety of test systems for assay of potentially hazardous agents. Comparative studies with genetic systems at various phylogenetic levels of development are the key to the approach.

The Section is divided into four research units, which have considerable overlap as well as interactions with other groups within the Biology Division and with other divisions of the Oak Ridge National Laboratory. These regearch units are labeled Comparative Mutagenesis, Mammalian Cellular and Molecular Studies, Genetics of Microorganisms and Drosophila, and Development and Reproductive Physlology. In each of these units there are research projects designed to provide a better understanding of the mechanisms of mutagenesis and gene expression and regulation. If these studies are to provide information to aid in the protection of the occupationally and generally exposed public from genetic hazards and co make posstble the prediction of (or the reversal of) such damage, more must be learned about the way in which genes act and are expressed. Thus, continuing and parallel research yielding knowledge of gesetics and reproduction in a variety of organisms, including man, must accompany or precede the development of test systems.

There are also inter- and intradivisional programs and intcractions that involve facets of the Comparative Cenetics Section, as examples, the recently instigated Biotechnology Program and the health offects research project within the Life Sciences Program in synthetic fuels. Furthermore, the Section contributes to graduate training in genetics within the University of Tennessee-Oak Ridge Graduate School of Blomedical Sciences.

In the area of genetic toxicology the main effort is the development and validation of assays for mutagenicity and teratogenicity. When coupled to the efforts in the other Sections, the array of bloassays represents a rather complex coverage of testing procedures in genetic toxicology.

The assays encompass bacteria (DNA repair and mutagenesis in Salmonella, E. col1, and Haemophilus), fungal systems (mutagenea is in yeast and Neurospora), Drosophila (sex-linked recessive lethal tests, nondisjunction, chromosome damage, and sister chromatid exchanges), amphibia 
(teratogenesis and embryo toxicity), mammalian cells in vitro (mutagenesis, chromosome aberrations, DNA repair, and sister chromatid exchanges), and mammalian celis in vivo (chromosome aberrations, mutagenesis, and sister chromatid exchanges). The individual research summaries provide detalls of these varfous research programs. The point to be emphasized here is that information from short-term and longer-term assavs using a wide variety of different systems provides a basis for extrapolation to potential effects in man.

Several aspects of the program are involved rather directly with extrapolations to man. The most direct approaches are naturally those involving studies on mammalian systems, such as in vivo/in vitro cytogenetics or mutations assayed in mammalian hemoglobins. Other less direct approaches involve comparisons between Drosophila and mouse. Since it is possible that mutagenicity is predictive of carcinogenicity (a correlation befing studied by a number of investigators within the Section and in other institutions), it is hoped that mutagenicity assays can be used to predict the potential carcinogenicity of a compound to man. Finally, the Development and Reproductive Physlology unit is involved in a varlety of studies concerned with the teratogenicity and embryo toxicity of pollutants in amphibian systems. Validation of these endpoints as compared to mamnalian systems could lead to a useful test system for the prediction of simllar effects in man.

In order to better interpret the data from these varlous assays and to extrapolate to effects in man, it is essential that the underlying mechanisms of mutagenesis, carcinogenesis, teratogenesis, and clastogenesis be determined. It is clear that DNA repair is involved in the process of mutation Induction, and a comprehensive study of the enzymology of repair is being carried out. Under this category is included the collaborative intersectional efforts in the area of molecular biology. Detalled studies of recombination and gene expression in Drosophila provide basic information towards understanding mutation induction.

Other mechanistic approaches involve the study of metabolic activation whereby nonmutagenic compounds are metabolized into mutagenic forms, and the study of the relationshlp between the structure and mutagenic potential of related compounds, e.g., nitrosamines, polycyclic aromatic hydrocarbons, and aromatic amines. An end-product of mutagenesis research is information from which regulatory guldelines can be established. Several projects directly impinge upon regulatory guidelines, including interdivisional projects concerning the applicability of short-term tests and chemistry. Much of the developmental work on the use of short-term assays in the evaluation of health effects of coal conversiun and shale ofl technologies has been carried out within the Division under Interagency Agreements between the EPA and DOE. These contributions stand not only as examples of how our long experience in fundamental research can be applied to the problems of modern technology but also as examples of cooperation between teams of ilvestigators in various divisions of ORNL. 
The following summaries will indicate how individual research projects fit into the above statement of purpose and how the information obtained might be used to estimate genetic effects on man from environmental agents.

\section{COMPARATIVE MUTAGENESIS}
J. L. Epler
L. M. Kyte
F. W. Larimer
S. I. Simms
C. E. Nix
R. D. Wilkerson
L. C. Waters
W. Winton
A. A. Hardigree

The major goals of the Comparative Mutagenesis group are: (1) to provide, through a battery of short-term tests, an evaluation of the genetic effects of energy-related compounds and (2) to obtain basic information necessary for evaluating test results and for estimating possible genetic risks to man. This estimation of potential long-range health effects requires both a broad data base and an understanding of the bfological response. Such factors as metabolism, repair, genetic constitution, solubility, and method of exposure must be explored experimentally. The approach includes: (a) the use of a battery of short-term assays including bacterial, yeast, and Drosophila systems, (b) blodirected chemical characterization of actual process materials and wastes, (c) examination of the effects of biological factors on the response, (d) identification of basic biochemical mechanisms of mutagenesis in eukaryotic systems, and (e) development of a data base on the identified t.azardous chemicals. The benefits of such an approach are more confident estimates of risk from energy-related materials, the correlation of biochemical data with biological endpoints, and the comparison of tests with mammalian cells and intact animals. These comparative studies serve as a connecting link between short-term bloassays in simple systems and mammalian tests.

\section{Energy-Related Studies}

The Comparative Mutagenesis Group has continued research with energyrelated materials during this year. Emphasis has been placed on the following aspects of the health effects evaluation: (1) preliminary screening of actual products and/or effluents for mutagenesis using shortterm assays; (2) validation of these results in additional batterles of tests; (3) extension of the initial results with crude materials to actual compounds through fractionation. chemical characterization and identification; and (4) specific profect: involving (a) examination of the connection between mutagenesis and carcirogenesis, and (b) extrapolation of in vitro results to the whole animal. Funded studles (Fossil Energy) Included 
consideration of alternate methods of treatment of fuels in order to mitigate potential health effects.

Bacterlal Mutagenesis. Mutagenesis studies using the Salmonella histidine reversion assay developed by B. N. Ames were applied in the following areas: (1) isolation and identification of mutagenic agents in synfuels (with Analytical Chemistry Division); (2) comparative studies of mutagente compounds with various assays (with Analytical Chemistry Division); and (3) determination of relationships between chemical structure and mutagenic activity.

a. Isolation and Identificalion of mutagenic agents from synfuels. Separation by chemical class coupled with blological assays using Salmonella histidine reversion assays was used to isolate and identify mutagenic agents from synfuels. Earlier studies using acid/base separation demonstrated that mutagenic substances are present in the basic and neutral fractions. The mutagenic constituents have been concentrated into a single, chemically defined fraction of very high mutageulc activity. The organic constituents of the basic fraction are suspected to be mainly primary aromatic amines. Mutagenesis studies with a large number of suspect compounds revealed higher molecular weight (؟used ring) aromatic amines, azaarenes and nitrogen heterocyclics to be potent wutagens.

Significant mutagenic activities were also noted in the neutral fraction. The neutral fraction was subjected to further separation using Sephadex LH-20 column chromatography and the individual fractions were assayed for mutagenic activity. Mutagenicity studies in a series of reference samples representing coal liquefaction (SRC-II; H-Coal), coal gasification (UMD tars) and shale oll have indicated that the aliphatic constituents though contributing to the bulk of the neutral fraction were not mutagenic. The mutagenic activity was distributed in the polyaromatic hydrocarbon (PAH) fraction, the nitrogen containing PAH (N-PAH) fraction and the polar fraction. The polar fraction contained most of the mutagenicity associated with the neutral fraction (possible chemical classes: quinones and other oxygen-containing PAH's). However, in parallel with work at other laboratories, the key threats have been established as: basics - aminoanthracene(s) and aminophenanthrene(s); neutral - benzo(a)pyrene(s), fluoranthene(s), chrysene(s), and cyclopentylpyrene (s).

b. Relations'..P Detann mutagenesis and carcinogenesis. The key study on the relationship hetween microbial mutagenesis and skin carcinogenesis was carried out 1.: collaboration with J. M. Holland. A qualitative and quantitative comperison of biological activity of fractionated neutral materials from bor $\mathrm{H}$-Coal and SRC-II showed simllar results. The Salmonella histidine reversion assay and skin may agree qualitatively on the potency of a crude material but are responding quantitatively to different classes of molecules. For example, the most potent carcinogenic fraction in the neutral materials was the PAH fraction while the most potent mutagentc fraction was a "polar" neutral fraction which was low in cancer producing activity. This was not unexpected silice 
it was known that specific activities, especially of nitro- and aminosubstituted derivatives, weasure extremely high in the Ames system.

c. Structure-activity relationships. A coordinated study on nitrosamines involving the collaboration between the staff of the Blology Division, W. Lijinsky (Frederick Cancer Research Center, Frederick, Maryland) and T. K. Rao (Environmental Health Research and Testing, Inc., Research Triangle Park, North Carolina) was brought to a conclusion. A compilation, guest-edited by the investigators, will appear in the near future.

Within the last year we shifted our emphasis within this task away from microbial screening. The next sections fllustrate our move to a consideration of the comparative approach from a more fundamental and experimental view. Only a selected group of comparative compounds are under consideration.

\section{Yeast Mutagenesis}

The yeast Saccharomyces cerevisiae is an Ideal organism for the study of mutagenesis and DNA repair in eucaryotes. A principal advantage of this model eucaryote, not shared by mammalian systems, is an extensive body of genetic analysis concerned with the control of mutagenesis and the repair of damage to DNA. Nearly 100 mutations that affect sensitivity to radiation and chemical mutagenesis have been described. Three major epistasis groups that control the processing of DNA damage have been recognized: one group (RAD52) is required for the repair of double-strand breaks in DNA; a second group (RAD3) directs error-free excision-repair of pyrimidine dimers and other bulky (chemical) lesions; a third group (RAD6) is responsible for a form of error-prone repalr for nearly all induced mutagenesis. Since a fundamental understanding of the molecular nature of mutagenesis is necessary for interpretation, extrapolation and development of the health effects program, we have sought to exploit the exquisite degree of genetic control afforded by this system. The program addresses chemical mutagenesis in four basic areas: mutagenesis by alkylating agents, and attendant repair processes; mutagenesis by intercalating agents and their interplay with repalr; isolation, Identification and characterization of repair genes and their gene products, and the study of the interaction of repalr functions; and an analysis of the role that the DNA sequence plays in the targeting of mutations.

Alkylation Mutagenesis. Work this year has been directed toward characterizing the repair of alkylated nucleotide bases. Activities have been Identifled in cride extracts which liberate $\mathrm{N}-7$-methylguanine and $\mathrm{N}-3$ methyladenine from alcylated DNA. There is no evidence of elther the release or demethylation of the miscoding base 0-6-methylguanine. In vivo labeling experiments indicate that $\mathrm{N}-3$-methyladenine 18 rapidly remov : from DNA. These studies are being extended to include members of the KAL: eplstasis group. 
Frameshift Mutagenesis. The REV-dependence study has been extended to include five agents: quinacrine mstard (QM), 4-nitroquinoline-N-oxide (4NQO), the quinacridine mstard ICRI70, methylnitrosourea (MNU), and UV. RAD6 function is reguired for frameshift induction with all five agents. The two quinacridine mustards require all REV functions, while MiU and UV are largely REV-independent. A striking dichotomy was observed with 4NQO; although REV2-REV3 dependent, i.e. hypomutable in rev2 and rev3 mitants, revl strains were hypermutable, suggesting that $4 \overline{\mathrm{NQO}}$ lestons are rather specifically accormodated by REVI.

Repair Genes and Products. A new yeast DNA library has been prepared from $10-20 \mathrm{kbp}$ fragments inserted into the minichromosome vector YCp50. This library is being screened for the REVI and REV2 loci, with the ultimate intent of identifying and characterizing their gene products.

It was recently reported that the umuC and $D$ genes of E. coli have witagentc repair activity when transformed into yeast. We are constructing yeast and mamalian expression vectors containing umuC and $\underline{D}$ to study their effect in different host repair backgrounds.

Sequence Spacificity. A 400 bp segment of the AROI gene, comprising the $S^{\prime}$ non-coding region (indicated by mRNA/DNA mapping) and the initial coding region, has been sequenced. A sequence related to the ATATGACTC box common to the coordinately regulated genes of the general anino acid control system has been identified. Deletion mapping of the coding region has located several of the mutant alleles. New mutants have been constructed by in vitro mucagenesis. These new mutants will be utilized in analysis of sequence specificity of reversion.

Sequence analysis of the his4-38 frameshift indicates the possible involvement of quasi-palindromic regions forming unusual secondary structures responsible for localizing error-prone repair events. Sequencing revertants may indicate the nature of these events. A plasmid vector for recovering revertant sequences has been constructed.

New Initiatives. Several mammalian shuttle vectors have been constructed utilizing the phosphotransferase gene from In 5 . SV40 based and HSV-tk based vectors have been designed. These vectors are intended for gene marking and plasmid rescue or cosmid rescue with G418 aminoglycoside selection. Target genes are the Gardners proto-oncogene and cumor-specific gene (collaboration with Regan).

A study of the mutagenic and toxic effects of oxygen have been initiated with Adler. Anaerobic yeast show unusual oxygen sensitivity for killing. Anaerobic stationary cultures appear to lose oxygen resistance. The genetic basis of oxygen resistance is being investigated.

A preliminary investigation of the effect of lodo-cytidine in DNA on the recognition and cleavage by restriction endonucleases was initiated ir. collaboration with Rahn. Iodo-C blocks cleavage by BamHI, HIndIII and ECORII. 
III. Insect Mutagenesis

Genotypic Variation and Alkylation Induced Mutagenesis in Drosophila Males. Two obvious vays in which the genotype may play a major role in controlling the frequency of induced (or sponteneous) eutations are through metabolisn of promutagens and DNA repair. While ach is known about the mechanisas of alkylation-induced wiations in procaryotes the situation in eucaryotes is less well understood and $m y$, in fact, be inite different frow that described in E. coli or other procaryotes. Although wost of the investigation of alkylation Induced DNA repair in eucaryotes has been with Saccharomyces cerevisiae, recently several utagen sensitive mutants that are also defective in DNA repair have been characterized in Drosophila. Use of these utants in in vivo mutagenicity studies, coupled with biochenical analysis, should shed wre light on the wechanisus of alkylation-induced mitagenesis in Drosophila.

As a starting point we have been testing the effects of DNA repair. wutants on alkylation-induced wtagenesis in males. Highlights of our results to this point are as follows:

(1) In wales containing the wi-9 wutation, an excision repair defect, the methylating agents dimethylnitrosame (DMN) and methylnitrosourea (MNU) are hypomutagenic (In early spermatids and late spermatocytes) to the wildtype strains - ozegon-R, Canton-S, Hikone-R, and Berlin-K. The corresponding ethylating agents diettylnitrosamine (DEN) and ethylnit rosourea (ENU) are equally mutagentc in mei-9 and wild-type males.

(2) The reduction seen with DAN is not due to differences in metabolism.

(3) Early spermatids and late spermatocytes are 2- to 3-fold more sensitive than late spermatids and mature sperm to mutation induction by MNU and ENU. This is in contrast to ethylmethanesulfonate (EMS) and methylmethanesulfonate (MSS) where there is little or no specificity between postmeiotic germ-cell stages. We interpret this as: (a) differences in the level of initial alkylations or (b) the existence of a mutagenic repair process in early spermatids and spermatocytes. Experiments to distinguish between the two are in progress.

(4) The alkylating agents, DN, DEN, MNU, and ENU, produce mutations equally well in postreplication repair deficient, me1-4l, and wild-type males.

Preliminary experiments suggest that the expression of DNA repalr defects, in relation to mutagenesis, is different $I_{14}$ males and females. This is not unexpected, however, as in Drosophila melotic recombination is very different in the two sexes. Many of the repair defective mutants are also deficient in melotic recombination. Future plans include experiments designed to explore these differences in more detall. In our efforts to understand the role of DNA repair in mutagenesis of Drosophila, we will attempt to define the specific biochemical lesions of mei-9 and its temporal expression in spermatogenesis. 
A second major way the genotype may influence the frequency of mutations is by controlling the levels of mixed-function oxidases (MFOs). He have surveyed a numer of wild-type strains for differences in induced mutation frequency in response to the simple alkylating agents, DMN, DEN, and wethylethylnitrosamine (MEN). A number of differences that were strain, as well as concentration, dependent were found. When HNU or ENU were tested these differences were no longer observed, suggesting that the variation reflects differences in MFO activity. In order to gain further insight into these problems we began a collaborative effort with Larry Haters.

\section{Metabolism of Xenobiotics}

Metabolites of xenobiotics, and not the parent chemical, are wost of ten responsible for their adverse effects to health. Primiry metabolisw is via the cytochrome P-450-containing mixed-function oxidase (MF0) system. The iensitivity of a particular organism to the deleterious effects of a particular chemical is therefore directly related to the metabolic capabilities of its MFO system. In order to learn more about the relevant metabolic processes and about how the expression of the relevant enzymes is regulated, we are studying the MFo system in Drosophila. Advantages of Drosophila over mammalian systems for these studies include: (1) Drosophila is susceptible to the toxic and mutagenic effects of a wide variety of chemicals; (2) metabolism and biological effect occur within the same organism and within a short enough period of time to make relevant correlations between the two events; (3) the MFO system in Drosophila is amenable to blochemical characterization, e.g., microsomes prepared from extracts of whole flies contain fully one-half the content of cytochrome $P-450$ of those preparec from uninduced rat livers; (4) genetic variation exists in the constitutive levels of $\mathrm{MFOs}$, as well as in their inducibility, in Drosophila. These genetic differences can be further manipulated and exploited for studying the system.

The period covered by this report has been an exciting arid productive time for this research. Highlights of our progress are summarized as follcws:

(a) a-Hydroxylation via dimethylnitrosamine demethylase (DMN-d) is probably not the pathway for metabolic activation of DMN to a mutagen. Drosophila strains that are negative for this activity are as sensitive to mutation by DMN as positive strains. These conclusions are based on activities in whole body extracts; the possibility of equal DMN-d activity in the gonads of both positive and negative strains has not byen eliminated. The system can be used to determine the relevant pathway for DMN activation. These findings are vecy relevant to mamalian studies where DMN-d has been implicated, but not proven, in DMN activation. Althougin DMN-d does not appear to correlate with DMN-induced mutagenesis, it might relate to the toxicity of DMN. 
(b) Expression of MFOs is dependent on genotype and age. Some activities appear to be coordinately expressed, sone not. The finding of large differences in MFo activities among strains of the same species suggests that similar studies should be made in mouse strains, particularly those being used in tests for witagens. The unique patterns of MFO expression in Drosophila can be explofted by using genetic manipulation and nolecular probes (see d) to elucidate the mechanisus by which MFO expression is regulated.

(c) The structural gene for DiN-d has been localized on chromosome II, with evidence for an "enhancer" of this activity located elsewhere, probably on chromosome III. It will be of interest to more precisely locate the DeN-d gene on chromosome II with particular attention to its position relative to insecticide resistance genes that are known to exist on that chromosome. He find a positive correlation between DYN-dexpression and resistance to phenylurea anong the strains tested. The notion of an "enhancer" of an MFO that is located on a separate chromosome is novel and should be further studfed. Mapping the chromosomal location of those MFOs that appear to be coordinately expressed versus those that aren't should yield considerable insight into the overall question of how HFO expression is regulated. Drosophila is probably the only organism in which it is feasible to do these studies.

(d) DEN-d activity (and probably other MF0s) is positively correlated with a unique protein band as determined by sodium dodecylsulfate polyacrylamide gel electrophoresis. There is a possible correlation between the presence of this protein(s) and insecticide resistance. This unique protein band undoubtedly contains MPO proteins (certainly DMN-d) that are expressed in some strains and not in others. It provides a convenient handle that can be used in the cloning of specific MFo genes. These clones can be used to study the mechanism of MFO expression at the molecular level.

We believe that the techniques an's concepts developed from this research are basic and necessary for understanding the complex metabolic processes that result in adverse health effects. Many of the methods and concepts that develop from this study are applicable to other programs in the Division. In this regard, we have initlated a collaborative study with Dr. J. N. Dumont to assess the role of MFOs in the production of teratogenic effects in the frog. Puture plans include simjlar studies of the MFo system in mouse skin.

1. Brown, D. K., Maskarlnec, M. P., Larimer, P. W., Pranrls, C. W., Mobility of organjc compounds from hazardous wastes, In Progress Report on Toxicity of Leachates, U.3. Environment-1 Protection Agency, Environmental Monitoring Systems Laboratory, 1982, Las "igas, Nevada. EPA-600/S4-83-001, March 1983, pp. 1-5.

2. Cowser, K. R., Epler, J. L., Gehrs, C. W., Guerin, M. R., Klein, J. A., Health and environmental studies of H-coal process, in EPA 
Symposiun on Enyironmental Aspects of Fuel Conversion Technology VI, A Syaposiun on Coal-Based Synfuels, October 26-30, 1981. EPA-600/9-82-017, Sept. 1982, pp. 124-147.

3. Dellarinf, D. M., Epler, J. L., Health effects studies, in Proceedings of the Workshop on Environmental Control Technology for Coal Gasification, Palo Alto, CA, July 28-30, 1982. EPRI AP-3006, Contract WS 81-241-01, Apri1 1983, pp. 8-1 - 8-19.

4. DeMarini, D. M., Rao, T. K., Ho, C.-h., Ma, C. Y., Guerin, M. R., Hsie, A. H., Epler, J. L., Mutagenicity of PAH-containing fractions uf synthetic fuels, in Proceedings of the Third Symposiun on the ipplication of Short-Term Bloassays in the Fractionation and Analysis of Complex Environmental Mixtures, Raleigh, North Carolina, in press.

5. Epler, J. L., Fry, R. J. K., Rao, T. K., Lariner, F. H., Dumont, J. K., Schultz, T. H., Russe11, L. B., Generoso, W. M., Witsch1, H., Snith, L. H., Haschek, H. M., Holland, J. M., Bionedical response to products and effluents fron the University of Minnesota-Duluth gasifier. ORNL/TM-8821, September 1983.

6. Epler, J. L., Larimer, F. H., Maskarinec, M. P., Francis, C. H., Ecological and health effects bioassay results from coal conversion solid wastes, in EPA Symposium on Environmental Aspects of Fuel Technology VI, Denver, Colorado, in press.

7. Griest, W. H., Caton, J. E., Rao, T. K., Harmon, S. H., Yeatts, L. B., Jr., Henderson, G. M., Characterization of mutagenic coal fly ash and extracts. Int. J. Environ. Anal. Chen., in press.

8. Guerín, M. R., Griest, H. H., Epler, J. L., Hitschi, H., Comparative toxicological and chemical properties of fuels developed from coal, shale or petroleur. To be presented at the "Identification and Assessment of Environmental and Health Concerns" session of the Anerican Institute of Chenical Engineers, Anahein National Meeting, Anahein, California, May 20-24, 1984.

9. Holland, J. M., Ho, T., Rao, T. K., Epler, J. L., Ho, C.-h., Buchanan, M. V., Guerin, M. R., The distribution of dermal tumorigens in coal liquids: Relationship of dermal tumorigenicity and microbial mutagenicity. J. Appl. Toxicol., submitted.

10. Larimer, F. W., Morse, C. C., Beck, A. K., Cole, K. W., Gaertner, F. H., Isolation of the AROI cluster-gene of Saccharonyces cerevisiae. Mol. Cell. Biol. 3: 1609-1614, 1983.

11. Lifinsky, W., Epler, J. L., Rao, T. K., Comparison of mutagenic and carcinogenic properties - A critique, In deSerres, F. J. (Series ed.), Rao, T. K., LIjinsky, W., Epler, J. L. (Guest eds.): Topics in Chemical Mutagenesis, Vol. I, Genctoxicology of N-nitroso Compounds, Plenum Publishing Corp., New York, New York, in press.

12. Ma, C. Y., Ho, C.-h., Griest, W. H., Guerin, M. R., Rao, T. K., Preparative scale extraction of organic compounds from fly ash for mutagenic study. Environ. Mutagen., in press.

13. Ma, C. Y., Ho, C.-h., Quincy, R. B., Guerin, M. R., Rao, T. K., Allen, B. E., Epler, J. L., Preparation of ofls for bacterial mutagenicity testing. Mutat. Res. 118: 15-24, 1983. 
14. Ma, C. Y., Rzo, T. K., Ho, C.-h., Allen, B. E., Quincy, B. R., Guerin, M. R., Epler, J. L., Analytical and biological analyses of test materials from the synthetic fuel technologies. V. Evaluation of procedures employed in the sample preparation fo: sutagenicity testing. Mutat. Res., in press.

15. Ma, C. Y., Rao, T. K., Ho, C.-h., Griest, H. H., Epler, J. L., Guerin, M. R., Preparative scale organic extraction and mutagenicity analysis of fly ash. Mutat. Res., submitted.

16. Maskarinec, M. P., Larimer, F. W., Epler, J. L., Francis, C. W., Health effects bioassay results from coal conversion solid wastes, in EPA Synposium on Environmental Asper;s of Fuel Conversion Technology VI, A Symposiun on Coal-Based Synfuels, Oct. 26-30, 1981. EPA-600/ 9-82-017, Sept. 1982, pp. 329-340.

17. Nix, C. E., Brewen, B., McKinley, C. M., Epler, J. L., A comparison of the induction of $X$-linked recessive lethals by chemical mutagens in wild-type and excision repair deficient, mei-9a, Drosophila melanogaster males. Mutat. Res., in press.

18. Nix, C. E., Brewen, B., Hoore, D., Lijinsky, W., Epler, J. L., Ef fects of structural differenzes in aliphatic nitrosamines on mutation induction in Drosophila. Mutat. Res., in press.

19. Rao, T. K., Allen, B. E., Cox, J. T., Epler, J. L., Enhancement of mutagenic activity in Salmonella by contraceptive sterolds. Toxicol. App1. Pharmacol. 69: 48-54, 1983.

20. Rao, T. K., Epler, J. L., Lijinsky, W., Structure activity studies with N-nitrosamines using Salmonella typhimurium and Escherichia coli, in Bartsch, H., O'Nelll, I. K., Castegnaro, M., Okada, M. (eds): $\mathrm{N}$-Nitroso Compounds; Occurrence and Biological Effects. IARC Scientific Publication No. 41, International Agency for Research and Cancer, Lyon, France, 1982, Pp. 543-552.

21. Sayler, G. S., Reid, M. C., Perkins, B. K., Pagni, R. M., Smith, R. L., Rao, T. K., Epler, J. L., Morrison, W. D., DuFrain, R., Evaluation of the mutagenic potential of bacterial polychlorinated biphenyl biodegradation products. Arch. Environ. Contam. Toxicoi. 11: $577-581,1982$.

22. Schultz, T. W., Dumont, J. N., Rao, T. K., Guerin, M. R., Ma, C. Y., Epler, J. L., Evaluation of hydrotreatment as a means of reducing biological activity of synfuel related materials. Environ. Res. 29: $389-398,1982$.

23. Waters, L. C., Nix, C. E., Epler, J. L., Studies on the relationship between dimethylnitrosamine-demethylase activity and dimethylnitrosamine dependent mutagenesis in Drosophila melanogaster. Chem.-Biol. Interact., 46: 55-66, 1983.

24. Waters, L. C., Nix, C. E., So,den, K. M., Epler, J. L., Effects of genotype and age on mixed-function oxidase activities in adult Drosophila melanogaster. Mutat. Res. Lett., in press. 
mayalian CELL GeNETIC TOXICOLOGY
A. H. Hsie
L. Rectol
P. A. Brimer
R. L. Schenley
D. M. DeMarini ${ }^{3}$
L. F. Stankowski 1
R. Machanoff
K. R. Tindall
S. W. Perdue

Our long-range goal is to study the mechanisms of mamalian gene mutations and to deternine the mutagenic effects of environmental agents associated with earergy technologies. We have used the following multiphasic mamalian gene mutational systems at the molecular, cellular and antnal levels to achieve this goal.

1. Quantitative Mutagenesis with CHO/HGPRT Assay: Studies of Mechanism of Mutagenes 18 and Environmental Mutagenesis.

A. Molecular dosinetry of nitrosourea mutagenesis. We have used the Chinese hanster ovary cell/hypoxanthine-guanine phosphoribosyl transferase (CHO/BGPRT) assay to quantify cytotoxicity and mutation at the hgprt locus induced by various chenicals. Earller, we found that this assay is useful to study structure-mutagenicfty relationships as exemplified by a study with ten direct-acting alkylating chemicals. Within each structurally related group (nitrosamidines, nitrosamides, alkyl alkanesulfonates and alkylsulfates), chemical reactivity (s value) decreases with the size of the alkyl group with the methyl agent being more mutagenic and cytotoxic than the corresponding ethylating chemical on an equimolar basis but not equitoxic level. Both the toxic nature and the DNA lestons induced by a chemical affect the determination of mutagen potency. For example, MaNU is 5 times more mutagenic than ENU on a molar basis, however, MNU is only one-half as mutagenic as ENU at the equitoxic level because MNU is more toxic than ENU. DNA binding studies showed that MNU has 15 times the alkylaing activity of ENU. Thus, ethylation of DNA appears to produce more mutants than the corresponding methylation. This is consistent with our recent observation that a higher proportion of $0^{6}$-ethyl-guanine was produced after ENU treatment as compared with $0^{6}$-methyl-guanine formed from MNU and the longer persistence of the ethylated than the methylated DNA adducts.

B. $0^{6}$-Methyl dGTP and mutagenesis in the CHO/HGPRT assay. The deoxynucleotide pool 18 a target of alkylating agents and alkylated nucleotides are Incorporated into DNA during in vitro replication. Incorporation of alkylated nucleotides may be an important mutagenic mechanism, and in fact Incorporation of $0^{6}$-methyldeoxyguanosine triphosphate ( $\mathrm{m}^{6} \mathrm{dGTP}$ ) during in vitro replication of phage $T 7$ DNA 18 mutagenlc. We have analyzed the fate of mbGTP and found $1 t$ to lack mutagenicity in mammalian cells In vivo. Using a calcium phosphate-mediated CHO/HGPRT assay, significant amounts of $m^{6} \mathrm{dGTP}$ can be introduced into CHO cells. Using $m^{6}\left[8-3_{H}\right] \mathrm{dGTP}$, wa found that intracellular uptake of $\mathrm{m}^{6} \mathrm{dGTP} 18$ concentration dependent; $1.5 \%$ of the added $\mathrm{m}^{6} \mathrm{dGTP}$ is taken up by $10^{6}$ cells during a $5 \mathrm{hr}$ treatment, with $3 \%$ of that belng converted into an ethanol insoluble form. Analysis of the 
ethanol ir soluble fraction shows that 25 of the label is incorporated into DNA (reledsed as deoxyguanosine), while $75 \%$ is found in RNA (released as guanosine); no label is released fron DNA as $0^{6}$-nethyldeoxyguanosine ( $\mathbf{n}^{6} \mathrm{dG}$ ). Since $\mathrm{CHO}$ cells have no detectable methyltransferase activity, it appears that $\mathrm{n}^{6} \mathrm{dGTP}$ enters the nucleotide pool where it is converted to d $\mathrm{dG}$ and then denethylated by adenosine deaninase. In separate experiments, concentrations of unlabeled $\mathrm{m}^{\circ} \mathrm{dGTP} u$ "were sufficient to introduce up to $5 \times 10^{9}$ molecules of $\mathrm{m}^{6} \mathrm{dGTP}$ into each cell without appreciable cytotoxicity or mtation induction. It thus appears that this alkylated nucleotide is not incorporated into cellular DNA and is therefore not utagenic.

C. $0^{6}$-Methylguanine-DNA methy:-ransferase in mammalian cells. $0^{6}$-Hethylguanine-DNA methyltransferase activity was assayed in extracts of amalian cells which are proficient $\left(\mathrm{Mer}^{+}\right.$) or deficlent (Mer ${ }^{-}$) in the repalr of DNA methylation damage. The $\mathrm{Mer}^{+}$HeLa CCL2 cell strain was found to contain approximately 100,000 molecules/cell of methyltransferase, assuming that each molecule can dewethylate only one $\mathbf{m}^{6} \mathrm{G}$ residue, whereas a Mer ${ }^{-}$HeLa S3 strain contained no detectable activity. Constitutive methyItransferase activity was also lacking In extracts of CHO and v79 cells. No Induction of methyltransferase activity was observed in CHO cells which had been treated with N-methyl-N'nitrosoguanidine (MNNG) according to a protocol reported to render the cells resistant to alkylation-1nduced sister-chromatid exchanges. Preliminary experiments indicate that treatment of HeLa CCL2 cells with subtoxic doses of MNG results in reduced levels of methyltransferase for up to $24 \mathrm{hr}$ following treatment, rather than an adaptive increase in activity.

D. Mutageniclty of crude and neutral fractions of coal-liquified olls In the Salmonella and CHO/HGPRT assays. The neutral fraction of coal-11quified o1ls accounts for over $50 \%$ of the crude sample and contributes a large portion of the mutagenic activity as determined by the Salmonella histidine reversion assay. To determine what classes of compounds are responsible for the mutagenic activity of the neutral fraction, we have subfractionated this fraction by means of Sephadex LH-2O gel chromatography and tested the subfraction for mutagenicity in strain TA98 of Salmonella and in the CHO/HGPRT assay. We tested the crude, neutral fraction, and the following subfractions: allphatic, polar aromatic, and a mi:t are composed oL two suiffractions - one enriched in polycyclic aromatic hydrocarbons (PAHs) and one enriched in neutral nitrogen heterocyclics (N-PAH). Also, a liquifled blend of light and heavy fuel o1ls was tested before and after hydrogenation. The results in Salmonella in the presence of Aroclor-1254-1nduced rat 11ver S9 show tiat polar aromatic compounds account for most of the mitagentc activity of the neutral fraction. The mixture containing the PAH ar.d N-PAH subfractions was weakly mutagenic, and the allphat1c subfraction was not mutagentc. The liquified blend before hydrogenation was mutagenic, but this activity was eliminated after hydrogenation. All seven mixtures were highly cytotoxic to CHO cells when the cells were treated for $5 \mathrm{hr}$ at $37^{\circ}$ in a serum-free medium. Also, 3-4 times higher doses of the mixtures were needed in the presence of 59 in order to obtain cytotoxic responses simllar to those 
found in the absence of S9. However, none of the seven mixtures induced a clear magenic response in the CHO/HGPRT assay.

E. Mutagenicity and cytotoxicity of five antitunor ellipticines in the CHO/HGPRT assay and their structure-activity relationships in Salmonella. The magenfity and cytotoxicity of five antitumor compounds (ellipticines) were investigated in the CHO/HGPRT assay and in six strains of Salmonella. All five compounds (ellipticine, 9-methoxyellipticine, 9hydroxyellipticine, 9-aninoellipticine, and 2-methyl-9-hydroxyellipticine) were cytotoxic and witagenic in the CHO/HGPRT assay in the presence or absence of Aroclor 1254-induced rat liver S9, and all except the last compound were mutagenic in Salmonella. Based on the reversion pattern obtained in various frame-shift and DNA repair-proficient (uvrB ${ }^{+}$) or -deficient (UvrB) strains of Salmonella in the presence or absence of 59 , the first three compounds appear to cause frame-shift witations by both intercalation and covalent bonding with DNA; thus, these are classified as reactive intercalators. However, 9-aminoellipticine intercalates only weakly and may instead exert its mutagenic activity primarily (or exclusively) by forming a covalent adduct with DNA. Compared to the published antitumor data obtained in mice, the results in Salmonella and CHO cells suggest that the ability of ellipticine, 9-methoxyellipticine, and 9-hydroxyelipticine to intercalate with DNA, induce frame-shift mutations, and cause cell killing is associated with and may be the hasis for their antitumor activity. The observation that the ellipticines are mutagenic in mammalian cells suggests that these antitumor agents may be carcinogenic.

\section{Cytogenetic Studies with CHO Cells.}

Methylphosphonic dichloride as a potent clastogen. Using the CHO multiplex system which measures cytotoxicity, gene mutation, chromcsome aberrations and sister-chromatid exchanges showed that methylphosphonic dichloride (MPOD), manufactured by the Ethyl Corporation, is an efficient clastogenic agent with little or no activity to induce mutation at the hgprt locus. MPOD is an organophosphorous hallde that reacts readily with metals and organic compounds. As a result of hydrolysis, hydrogen chloride and methyl phosphonic acid are 11berated. To counteract the acidic nature of MPOD, treatment is conducted with 20 miMes buffer ( $\mathrm{pH} 7.4$ ) in serumfree F12 medium. MPOD is quite cytotoxic with no cell survival above $120 \mu \mathrm{g} / \mathrm{ml}$. At a concentration of $48 \mu \mathrm{g} / \mathrm{ml}$, which reduces survival to $20 \%$ but does not induce mutations, there are 76 SCE's per cell (control value 12) and $38 \%$ of the mitotic figures were aberrant with 3 chromosome aberrations per cell of the chromatid type (control gave no aberrations). At a concentration of $72 \mu \mathrm{g} / \mathrm{ml}$ which rendered a $17 \%$ Burvival without Inducing mutations, $76 \%$ of the cells exhibited aberrant metaphases with 3 chromosome aberrations per cell of the chromatid type. The comp.srison of MPOD with known clastogenic, mutagenic and carcinogenic agents for the Induction of SCE's and chromosome aberrations should be of interest in regards to the relationsip of clastogenesis to mutagenesis and carcl nogenesis. 


\section{Molecular Anslysis of Mammalian Cell Gene Mutation.}

An analysis of gene mutation in DNA-transformed CHO cells. We have Isolated a CHO cell line which carries a single, stable, functional copy of the E. colf xanthine-guanine phosphoribosyl transferase (XGPRT) gene (gPt). This line was obtained after introduction of the plasm't vector pSV2gpt Into a HGPRT ${ }^{-}$, presumptive deletion mutant CHO cell line the transformant expresses the bacterial purine salvage enzyne, XGPRT. $\mathrm{gPt}^{-}$matants can be recovered by selection for 6-thioguanine $(10 \mathrm{~m})$ activity. UV-light and $\mathrm{X}$-ray Irradiation show a dose dependent induction to $\mathrm{TG}^{\mathrm{r}}$. This $\mathrm{gpt}^{+}$ce:l line is hypersensitive to killing by $U V-$, but not $X$-ray irradiation (versus wild type CHO cells) and there is a 2-20 fold increase in mutation induction at the gpt locus versus the hgprt locus depending upon the dose and type of radiation. Southern blot hybridization detected deletions through gpt structural gene sequences in the two $\mathrm{TG}^{\mathbf{r}}$ mitants analyzed: a deletion of $1.0 \mathrm{~kb}$ in a spontaneous wutant and of $3.1 \mathrm{~kb}$ in an $X$-ray Induced mutant. Additional $\mathrm{TG}^{\mathrm{r}}$ clones are being similarly analyzed. This gpt $^{+}$CHO cell line appears to be useful for quantitative and molecular analysis of gene mutation in mamalian cells.

4. Development of a Chinese Hamster Model System for Induction of Mutations In Vivo.

Detection of 6-thioguanine resistant spleenocytes from Chinese hamsters. An assay for the detection of specific locus mutant lymphocytes arising in vivo in the Chinese hamster is being developed. The method is based on the autoradiographic detection of $\mathrm{TG}^{\mathrm{r}}$ spleenocytes following in vitro mitogenic stimulation for $42 \mathrm{hr}$ in the presence or absence of TG. After removal of spleens from Chinese hamsters, $1 \times 10^{6}$ cells/ml suspensions are prepared. Dose-response relationships for two mitogens, Phytohemagglutinin (PHA) and Concanavalin A (Con-A), Indicate that a maximal response occurred between 1.8 and $2.7 \mathrm{Hg}$ of Con-A per ml. Using a concentration of $2 . \mathrm{Hg} / \mathrm{ml}$ of Con-A, five concentrations of TG were used for cytotoxicity determination with non-cryopreserved lymphocytes. These data indicate that a concentration of $2 \times 10^{-4}$ TG resulted 1 in an average variant frequency of $3.85 \times 10^{-6}(n=4)$.

1. Arneson, R. M., Wander, J. D., Cabot, M. C., Tan, E. L., Schenley, R. L., Hsie, A. W., Resistance to lipid peroxidation by cultured neoplastic cells, in McBrien, L. C. H., Slater, T. F. (eds.): The Second National Foundation for Cancer Research Symposium, Protective Agents in Humans and Experimental Animals, Academic Press, 1983.

2. Puscoe, J. C., O'Ne111, J. P., Machanof $f$, R., Hsie, A. W., Quantification and analysis of reverse mutations at the hgprt locss in Chinese hamster ovary cells. Mutat. Res. 96: 15-30, 1982. 
3. DeMarini, D. M., Cros, S., Paoletti, C., Lecointe, P., Hsie, A. W.. Mutagenicity and cytotoxicity of five antitumor Ellipticines in mammalian cells and their structure-activity relationships in Salmone1la. Cancer Res. 43: 3544-3552, 1983.

4. Ho, T., San Sebastian, J. R., Hsie, A. W., Mutagenic activity of nitrosamines in mammalian cells: Study with the CHO/HGPRT and human leukocyte SCE assays, in Rao, T. K., Lijinsky, W., Epler, J. L. (eds.): Topics in Chemical Mutagenesis, Plenum Publishing Corp., in press.

5. Hsie, A. W., Gene mutation, quantitative mutagenesis and mutagen screening in mammalian cells: Study with CHO/HGPRT system, in Nicolini, C. (Ed.): Cell Growth, New York, Plenum Publishing Co., 1982, pp. 715-721.

6. Hsie, A. W., 0'Nell1, J. P., San Sebastian, J. R., Brimer, P. A., Tan, E. L., Quantitative mammalian cell mutagenesis and mutagen screening: Study with Chinese hamster ovary cells, in Kolber, A. R., Wong, T. K., Grant, L. D., DeWaskin, R. S., and Hughes, T. J. (eds.): In Vitro Toxicity Testing of Environmental Agents, Part A, Plenum Publishing Corp., 1983, pp. 283-302.

7. Hsie. A. W., Schenley, R. i., Utilization of Chinese hamster cells in viti: ind in vivo in genetic toxicology: A multiphasic approach. Environ. Mutagen., in press.

8. Hsie, A. W., Schenley, R. L., Tan, E. L., Perdue, S. W., Williams, M. W., Tan, T. L., Hayden, T. L., Turner, J. E., The toxicity of sixteen metallic compounds in Chinese hamster ovary cells: A comparison with mice and Drosophila, in Goldberg, A. M. (ed.): Symposium in Acute Toxicity Testing: Alternative Approaches, Mary Ann Liebert Publishers, Inc., New York, in press.

9. Hsie, A. W., Schenley, R. L., Tindall, K. R., Machanoff, R., Brimer, P. A., Perdue, S. W., San Sebastian, J. R., Tan, E. L. and Albertini, R. G., The need to dcvelop a short-term in vivo assay for specific locus mutation in the Chinese hamster, in Banbury Report XIII. Cold Spring Harbor Laboratory, Cold Spring Harbor, New York, 1982, pp. 487-500.

10. Legator, M. S., Beuding, E., Batzinger, R., Conner, T. H., Elsentadt, B., Farrow, M. G., Ficsor, F., Hsle, A. W., Seed, J., Stafferd, R. S., An evaluation of the host-mediated assay and body fluid analysis: A report of the U.S. Environmental Protection Agency Gene-Tox Program. Mutat. Res. 98: 319-374, 1982.

11. Tan, E. L., Brimer, P. A., Schenley, R. L., Hsie, A. W., Mutagenicity and cytotoxicity of dimethyl- and monomethyl-sulfate in the CHO/HGPRT system. J. Toxicol. Environ. Health 11: 373-380, 1983.

12. Tindal1, K. R., Hsie, A. W., Detection of deletion mutations at the gpt locus in pSVgpt transformed CHO cells, in UCLA Symposium, in press. 
MAMMALIAN CYTOGENETICS
M. J. Aardema 1
H. E. Luippold
W. W. Au
J. P. O'Neill
P. C. Gooch
M. W. Heartlein 1
H. S. Payne
T. Ho
R. J. Preston

We have continued our studies of the mechanisms of induction of chromosome aberrations and sister chromatid exchanges (SCE) by chemical and physical agents, and the application of this knowledge to improve the basis for estimating the genetic and carcinogenic risk to man from exposure to such agents. We are also using these mechanistic approaches for the determination of the possible reasons for differences in sensitivity to the induction of chromosome aberrations and SCE in the same cell types of different species and different cell types within a species. We have also applied our information for conducting human population cytogenetic monitoring studies and interpreting the data.

1. Induction of Chromosome Aberrations by Fission Neutrons and $X$ rays. In a series of experiments (Preston, R. J., Mutat. Res. 69: 71, 1980; Preston, R. J., Cytogenet. Cell Genet. 33: 20, 1982) we have shown that cytosine arabinoside (ara-C) inhibits the excision repair process at the repair replication stage, thereby causing the accumulation of single strand gaps in the DNA. On reversing this inhibitory effect with deoxycytidine, the accumulated gaps can interact to produce chromosome aberrations. If $G_{0}$ human lymphocytes are $X$-irradiated, incubated with ara-C for 1,2 or $3 \mathrm{hr}$, and then stimulated with phytohemagglutinin, with the addition of deoxycytidine, there is a considerable increase in the frequency of chromosome-type aberrations compared to the frequency in cells that are irradiated but are not incubated with ara-c. There is an approximately linear increase with increasing ara-C incubation times. These results indicate that $X$-ray-induced chromosome aberrations are the result of the interaction of coincidentally repairing base damages. Further, it was shown that the increased frequency of $X$-ray-induced chromosome aberratione in $G_{0}$ lymphocytes of Down syndrome individuals is the result of a more rapld repair of base damage in lymphocytes of these Individuals than in normal lymphocytes (Preston, R. J., Environ. Mutagen. 3: 85,1981$)$. The more rapid repair will increase the probability of there being coincidentally repalring base damage reglons able to interact to produce aberrations.

- When $G_{0}$ human lymphocytes were Irradiated with fission neutrons and incubated with ara- $C$ for $1-5 \mathrm{hr}$, no increase in aberrations was observed compared to cells irradiated with neutrons alone. The RBE for the fisaion neutrons compared to $X$ rays was about 5 . Since we have shown that ara-C does not Inhibit the repalr of directly induced DNA strand breaks (H188, E. A., Preston, R. J., Bloch1m. Blophys. Acta 478: 1, 1977), 1t appears chat the chromosome aberrations induced by neutrons result from the interaction of directly-induced DNA strand breaks, in contrast to their 
Induction by $X$ rays. This observation has several Important Implications, and additional evidence suggests that it is indeed tenable.

It was suggested above that the increased frequency of $\mathrm{X}$-ray-induced chromosome aberrations in $G_{0}$ Down lymphocytes was the consequence of a more rapid repair of base damage in these cells than in normal lymphocytes. If neutrons induce aberrations by the interaction of directly induced double strand breaks, then there should be no difforence in the neutron-induced aberration frequency between normal and Down lymphocytes, since the DNA contents of the two cell types are about identical. Experiments reported by DuFrain et al. (Radiation Research Soclety Meeting, San Antonio, March, 1983, Abstract Cd3) show that this is indeed the case.

Recent experiments In our laboratory (Heartlein, M. W., Preston, R. J., unpublished) have shown that the differences in sensitivity to $x$-ray-induced chromosome aberrations in the lymphocytes of different species (human, marmoset, pig and rabbit) are the result of differences in the rate of repalr of ara-c Inhlbitable damage (base damage). However, since these species have similar DNA contents they should not show the same differences in sensitivity to neutron-induced aberrations as shown for $X$-ray-induced aberrations, 1.e., the RBE should be different for different species. Inttial studies comparing $X$-ray- and neutron-induced aberration frequencies in human and pig lymphocytes have confirmed this hypothesis. The frequency of dicentrics induced by $X$ rays in pig lymphocytes is about one-half that for human lymphocytes, whereas the frequencies are, as predicted from the simllarity in DNA contents, about the same following neutron Irradiation. The RBE for the human cells is about 5 whereas it is about 8 for the pig. Thus in any particular cell type the RBE for chromosome coerrations will be proportional to the ratio of misrepalred double-strand breaks to misrepaired base damage, and can clearly vary from cell type to cell type or from species to species for a particular radiation quality.

It has also been shown that the rate and extent of repalr of ara-c inhibitible damage, as indicated by increases in the frequency of chromosome aberrations in cells $\mathrm{X}$-irradiated and incubated with ara-C, is dose dependent. The rate of repair is decreased as the $X$-ray dose is decreased, and the overall increase in aberrations in the presence of ara-C is lower at lower X-ray doses. At a dose of 50 rad there 18 no increase in aberration frequency in the presence of ara-C. These results indicate that at low $X$-ray doses ( $<50$ rad) the aberrations probably result from the interection of directly-induced double strand breaks, which 18 perhaps predictable since the probability of aberrations resulting from the interaction of repalring base damages will be low because of the low frequency of induction of base damages. It can also be argued that the linear quadratic dose response for chromosome aberrations induced by $X$ rays 1s a consequence of the Induction of the initlal damage by one or two lonization tracks, and also the fact that as the dose 18 increased the Induced base damages are repaired at a faster rate, and there w111 be a greater probability of interaction of repalring damage that can result in aberrations. 
The aberrations induced by fission neutrons result fron the interaction of directly-induced double-strand breaks, with perhaps some contributir.n at high doses ( $>40$ rads) due to the interaction of repairing base damages, when the induced frequency of base damage could be suffiziently high that its involvement in aberration induction could be observed over and above the large contribution of double-strand breaks. This latter point is befing checked. The aberrations lnduced by $X$ rays are the result of the interaction of directly-induced double-strand breaks at doses of $50 \mathrm{rad}$ or lower, but at higher doses the major mechanism of induction is from the interaction of repairing base damages. The RBE will be a reflection of this.

Two other conclusions can be drawn from these experiments. Firstly, the target size for $x$-ray-induced aberration at doses above 50 rads can be large since the base damages can be induced some distance apart - the only requirenent is that they be close together (within the rejoining distance) at the time of repair, and that they can interact. The target size for neutrons is likely to be much smaller because the interacting double-strand breaks are induced by a single ionization track, and are repaired much more rapidly and consequently will be induced in close proximity. Secondly, a limiting $R B E$ can be calculated for fission neutrons compared to $X$ rays, because at low $X$-ray doses the damage resulting in aberrations is directlyinduced double-strand breaks, as is the case with fission neutrons, and so a calculation of RBE for chromosome aberrations at these low X-ray doses will reflect a comparison of aberration frequencies where the aberrations result from the same mechanism of induction. This assumption does not hold zrue at higher $X$-ray doses (>50 rad).

These studies are continuing, and hopefully will give a much better understanding of the mechanism of induction of chromsome aberrations over a range of radiation qualities, and a means whereby RBE can be calculated or estimated with regard to the mechanisms of induction of aberrations.

2. Mechanism of Induction of S1ster Chromat1d Exchanges and Specific Locus Mutations. In order to be able to obtain chromosome differentiation for analysis of SCE in cells, it is necessary to grow cells in a medium containing a thymidine analog, usually bromodeoxyuridine (BrdU). It has been shown that the incorporation nf BrdU or its replication causes SCE, and the SCE frequency is higher at higher extracellular BrdU concentratlons. We found that we could use chlorodeoxyuridine (CldU) Instead of BrdU, and that differentially stained chromosomes could be obtained after two rounds of replication in CldU. However, it was observed for Chinese hamster ovary cells that the frequency of SCE when CldU was used was about 7 times that when BrdU was used, for equimolar extracellular concentrations. The frequency of mutations at the hgprt locus (thioguanine sensitivity to thioguanine resistance) following growth for two rounds of replication in elther $C l d U$ or BrdU was appproximately the same.

It was important to determine if this difference in the frequency of induction of SCE was due to the difference in incorporation into replicating DNA for CldU and BrdU, even though the extraceliular concentrations 
were the same. We used HPLC to determine the incorporation of the two analogs over a concentration range in the medium of 1.5 to $20 \mathrm{H}$. The two analogs were incorporated to the same extent over this concentration range. The frequency of SCE was linearly proportional to substitution for thyoldine by CIdU and BrdU. Based on a linear extrapolation, a spontaneoue level of approximately 6 SCE per cell was estimated.

The fact that CldU induces about 7 times as many SCE as BrdU or equal substitution for $d T$ in Chinese hamster ovary cells in culture allowed us the opportunizy to study the mechanism of induction of SCE by these two analogs. Cultures were incubated with efther BrdU or CldU for one cell cycle, followed by incubation in the presence of $\mathrm{dT}$ alone or $\mathrm{BrdU}$ or $\mathrm{CldU}$ for the second cell cycle, and the SCE frequency was determined in M2 cells. The results showed that the induction of SCE is dependent only on the replication of the analog-substituted DNA, during the second cell cycle. Additional studies used cultures grown in the presence of BrdU or CldU for 7 days to obtain mainly bifilarly-substituted DNA, followed by two rounds of replication in the presence of dT alone. The SCE frequencies were approximately twice those found in cultures which had undergone the usual two rounds of replication in the presence of the analog. This is consistent with the hypothesis that SCE result from errors of replication of analog-substituted DNA.

The mutant frequency at the hgprt locus from long-term growth of cells in BrdU or CldU was dependent on the concentration of the analog in the medium. Also the frequency of mutants in cells grown in C1dU was about 7 times that for cells grown in BrdU - a simflar ratio to that found per SCE. This is interpreted as being a consequence of the induction of specific locus mutation by errors of replication of the analog-substituted DNA, with more errors resulting from the replication of cldU-containing DNA. In addition, only at high concentrations of BrdU or CldU ( $>50 \mu M$ ) are autants induced from the two rounds of replication. At concentrations of $50 \mu \mathrm{M}$ and above there is a $100 \%$ substitution of thymidine by BrdU and CldU. Thus the mutant frequency increases over a concentration range where there is no increase in substitution of BrdU or CldU for thymidine. The mutants induced appear to be a consequence of misincorporation of BrdU or CldU into replicating DNA, quite possibly in place of cytidine, since the addition of $\mathrm{dC}$ results in a decrease in the mutant frequency.

These results are not only important as regards the mechanism of Induction of SCE and specific locus mutations, but also because they appear to provide a way by which the sensitivity of the assays for the two end-points can be considerably increased. This could prove to be of significant benefit particularly in human population monitoring studies.

3. Human Population Monitoring Studies. In conjunction with the Centers for Disease Control (Atlanta) and Dr. M. A Bender of the Brookhaven National Laboratory we conducted a cytogenetic monitoring study of persons who had resided in the area of the Love Canal and a matched control group In nearby Niagara Palls. The study was designed to determine 
if there were any demonstrable differences in the frequencies of chromosone aberrations or SCE in the two groups.

Frequencies of chiomosomal aberrations and/or sister chromatid exchanges (SCE) were measured in peripheral blood specimens obtained between December 1981 and February 1982 from 46 persons. Bland analyses were performed with 44 matched control specinens from persons living in another part of Niagara Falls. Two sets of Love Canal participants were included. The first group consisted of 29 persons who in 1978 lived in 7 of 12 howes directly adjoining the canai, in which air, water, and soil testing showed elevatet levels of chemicals spreading from the canal. The second group inclijed 1? persons in whon cytogenetic analyses had been perforwed in 1980 as part of a pllot investigation supported by the U.S. Environnental Protection Ageniv.

In neither group did frequencies of SCE or chromosomal aberrations (such as gaps, breaks, fragments, or "supernumerary acentrics") differ significantly from control levels. Karyotypes were normal in all specimens. In assessing chromosome damage, several factors of interest sex, cigarette smoking, history of playing on the canal site, and history of attendirig an Elementary school that adjolned the site - were examined as possible causes of cytogenetic variation. History of current cigarette smoking was significantly associated with increased SCE frequency, a result observed independently in studies elsewhere. Other factors, alone or in combination, were not associated with any significant increase in chromusome damage.

In May 1980 results of an earlfer cytogenetic study led to concern that chromosome damage might be increased among residents of the Love Canal area. Results of the present study do not support that conclusion and indicate instead that the chromosome alteration frequenctes are the same in Love Canal residents as in residents elsewhere in Niagara Falls. Interpretation of these findings are limited by (1) considerable passage of time since 1978 when homes adjoining the canal were evacuated and corrective drainage work began at the site, and (2) lack of objective measurements for canal-related chemlcal exposures in individual residents. Although cytogenetic changes in peripheral blood lymphocytes are known to persist for years after exposure to lonizing radiation, simllar persistence after chemcial exposures may not necessarily occur.

Cytogenetic studies may prove useful in the future in assessing subclinical toxic damage in situations where tests can be done at the time of exposure or soon after, and where individual exposure can be readily measured. Present experfence, however, suggests that while cytogenetic measurements of this sort may provide good correlations with doses of radiation or toxin, their predictive value for future individual health is quite uncertain.

Also in confunction with Dr. Bender (BNL) we are analyzing the frequencies of SCE and chromosome aberrations in about 400 persons employed ar. BNL. This project is funded by the National Toxicology Program. The 
selected sample group has been established such that approxinately equal numbers of Individuals are included in each age decade, that males and females are approximately equally represented, and that different races are represented (although not necessarily equally). A medical record can be obtained at a later date. The purpose of the study is to obtain a value for the background frequency of SCE and chromosone aberrations, with particular emphasis on the variations in these frequencies, and possible intrinsic or extrinsic factors that could be responsible for any variations. To date samples from some two hundred individuals have been analyzed. The results will not be completely assessed unt 11 all samples have been analyzed so that there will be no opportunity for bias in interpretation based upon a partial sample.

4. Studies on the Induction of Chromosome Aberrations in RFM Mouse Bone Marrow, and their Possible Relationship to Myelogeous Leukemia. In order to understand the clastogenic and carcinogenic potential of neutron irradiation, we have initiated a project in coilaboration with Dr. R. L. Ullrich to study the dose-response relationship for the induction of chromosome aberrations and of myeloid leukemia in RFM mice by fission neut rons.

It was felt that in order to study induction of aberrations in bone marrow cells it was necessary to determine the specific cell stage in which the cells analyzed were at the time of irradiation, because different cell stages have different sensitivities to aberration induction. In addition, different types of aberrations are induced in different cell stages, and their consequences can be quite different, particularly with regard to probability of transmission through many cell divisions. For this type of analysis we decided that the proliferation kinetics of these cells needed to be elucidated since the bone marrow is composed of heterogeneous cell types. Our recent study of the cell cycle kinetics of normal mouse bone marrow cells shows that the average cell cycle time for different populations ranges from 5.75 to $30 \mathrm{hr}$. If these phenomena are not taken into consideration in the analysis of chromosome aberrations, the aberrations induced in different cells at different phases of the cell cycle will be indiscriminately considered together. In order to overcome such difficulties we have been developing a program to combine the analysis of cell proliferation and cell cycle specific induction of aberrations in the bone marrow cells. This requires the in vivo incorioration of bromodeoxjuridine (BrdU) Into newly synthesized $\overline{D N A}$ and subsequent staining of the chromosomes to reveal the amount of cell progression. The cell that has progressed from the non-S- or the S-phase through one, two or three cell cycles can be readily identified. If the first post-treatment metaphase cells are analyzed, the aberrations induced in the non-S phase (presumably $G_{1}$ phase) and in the $S$ phase can be quantified separately.

We have inftiated the application of this protocol to study the induction of aberrations by neutron radiation in the mouse. Mice were individually housed in a rotating chamber, exposed to 40 rads of $\mathrm{fissi}$ ion neutrons, implanted with $35 \mathrm{mg}$ BrdU tablets, and bone marrow cells were harvested at 3 to $24 \mathrm{hr}$ after irradiation. Non-irradiated control mice 
were sinilarly housed and harvested. The stained cytological preparaticns were analyzed and wetaphases were categorized according to their staining patterns, which indicate the cell cycle progression. These maphases are given a score in order $t$ : calculate a proliferation index for comparison of the kinetics fron one wouse to another. If a cell has progressed through one complete cell cycle, the score is one. If a cell has progressed from the early $S$ phase to netaphase, this cell is considered to have progressed through half a cell cycle and the score is one half. If a cell has progressed from the very late $S$ phase when the $Y$ is the only chromosone to be replicated. the score is one quarter. Thus, a proliferation index can be calculated this: reflects the progression of the bone marrow cell. Our data show that the 40 . ads neutron irradiation caused a consistent delay in cell progression. The average delas was approxinately $2 \mathrm{hr}$ with this dose of radiation. Additional experiments are in progress to study the doseresponse relationship in neutron induction of cell cycle perturbation and of cell-cycle phase specific aberrations.

5. Analysis of Hunan and Mouse Myeloid Leukeala. We have recently developed a transpiantable wouse nyeloid leukemia model in which the leukemic cells can be unequivocally distinguished frow the co-existing normal cells in the bone marrow of the host aice. The leukemic sells can be readily identified due to the presence of a large marker chromosome identified as an isochromosome 8 by chromosome banding analysis. In addition, the cells also contain a deleted chromosome 2 which is characteristic of all mouse myelold leukemic cells analyzed by different investigaturs. The availability of this cell line will permit us to study the various responses of the leukemic cells to insult in vitro as well as the differential effects of normal and leukemic cells in the same animal.

The human counterpart of the mouse myeloid leukemic cells is most likely the human promyelocytic leukenla cell line HL60. This line was identified by chromosome banding to contain a translocation between chromosomes 10 and 13 , monosomy in chromosomes $5,10,14$ and 17 , deletions in chromosomes 9 and 13 as well as the addition of three marker chromosomes. This line is susceptible to induction of differention upon exposure to phorbo1-12-myristate-13-acetate. Sublines with various degrees of resistance to differentiation have been isolated and their resistance is assuclated with chromosomal alterations including gains or losses of chromosomes $5,8,11,13,16$ and 17 . It 1s suggested that acquisition of resistance to induction of differentiation may involve one or more of the above chromosomal changes.

The existence of both human and mouse wyelold leukemic cell lines will allow us to investigate whether specific responses are myeloid leukemia specific or species specific.

The studles described in the sections above are all continuing, and from them we hope to obtain information that we can eventually use to provide estimates of the genetic and carcinogenic risks to man from exposure to radiation and chemical agents. We are also developing new approaches, particularly with regard to the involvement of specific 
chrowome translocations and the relocation of oncogene sequences, to the induction of specific tuars.

1. Au, W. H., Luippold, H. E., Otten, J. A., Development of transplantable wuse meloid leukenia odel system: a prelininary report. Prog. Mucleic Acid Res. Mol. Biol., in press.

2. Heartiein, M. W., O'Neill, J. P., Preston, R. J., SCE induction is proportional to substitution in DAA for thynidine by CldU and BrdU. Hutat. Res. 107: 103-109, 1983.

3. O'Rell1, J. P., Heartlein, M. H., Preston, R. J., Sister chromatid exchanges and gene mitations are Induced by the replication of 5-bromo- and 5-chloro-deoxyuridine substituted DNA. Mutat. Res. 109: 259-270, 1983.

4. Preston, R. J., Cytogenetic studies in animals, in Proceedings of Symosium on Genetic Toxicology: An Agricultural Perspective, New York, Plenur Press, 1982, pp. 379-388.

5. Preston, R. J., Chromosome aberrations in decondensed spera, in Indicators of Genotoxic Exposures, Banbury Conference 13, Cold Spring Harbor Piress, 1982.

6. Preston, R. J., Cytogenetic abnornelities as an indicator of utagenic exposure, in Ansari, A, deSerres, F. J. (eds.): Single Cell Mutation Monitoring Systems: Methodologies and Applications, New York, Plenum Publishing Co., in press.

7. Preston, R. J., ine Use of Human Lymphocyte Assay for the Cytogenet1c Analysis of Human Populations, in Inrkasky, J. F. (ed.): Proceedings of the Ethylene Oxide Worker Safety Seminar, Washington, Health Industry Manufacterer's Association, in press.

8. Preston, R. J., Intrinsic Factors that can Affect Sensitivity ti Chromosome Aberration Infuction, In Sheridan, H., deSerres, F. J. (eds.): American-Swedish Workshop, New York, Plenum Publishing Co., in press.

\section{DNA 3EPAIR IN HUMAN CELLS}

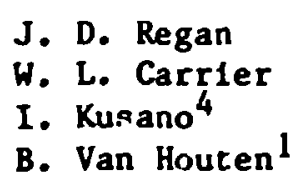

W. C. Dunn, Jr.

A. A. Prancis

P. A. Charp ${ }^{4}$

Our primary objective is to elucidate the molecular events in human cells when cellular macromolecules such as DNA are damaged by radiation or chemical agents. We study and characterize (1) the sequence of DNA repair events, (i1) the various modalities of repair, (iil) the genetic inhibition of repair due to mutation, (iv) the physlological inhibition of repair due to mutation, (v) the physlological inhibition of repair due to blochemlani inhibitors, and ( $v 1$ ) the genetic basis of repair. Our ultimate goals, are 
tr. (1) isolate and analyze the repair component of the mutagenic and/or carcinogenic event in human cells, and (ii) elucidate the magnitude and significance of this repair component as it inpinges on the practical problems of human irradiation or exposure to actual or potential chenical mutagens and carcinogens.

The significance of these studies lies in (1) the ubiquitousness of repair (most organisus, including man, have several couplex repair systens), (ii) the belief that mutagenic and carcinogenic events may arise only frou residual (nonrepaired) lesions or that error-prone repair systems may be the major induction mechanisms of the mutagenic or carcinogenic event, and (iii) the clear association of repair defects and highly carcinogenic disease states in man [xeroderma pigmentosum (XP)].

Jltravinlet light induces dimer formation between adjacent pyrimidines in DNA of cells resulting in a variety of deleterious effects. We have studied the UV-light induction and excision of pyrimidine dimers in the DNA of amalian cells. The number and kinds of dimers formed in DNA is related to the wavelength of UV-light, pyrimidine content, and the total dose. Also, the number of dimers produced in cells growing in a monolayer way differ by a factor of 2 and is attributable to cell shape. In human cells, a low dose of $254 \mathrm{~nm}$ light produces cytosine-cytosine, cytosinethymidine and thymidine-thymidine dimers at a ratio of 16:24:60 while a low dose of simulated sunlight produces dimers at a ratio of 20:40:40. The number of cytosine-cytosine dimers saturates at $50 \mathrm{Jm}^{-2}$ of $254 \mathrm{~nm}$ light and never exceeds $0.05 \%$ of total pyrimidines independent of the wavelength used for irradiation. Normal human ceils are able to excise $10^{6}$ dimers from their DNA in a day following irradiation with $254 \mathrm{~nm}$ light or simulated sunlight. Mouse cells in culture are deficient in their ability to excise dimers as measured by bromodeoxyuridine ( $\mathrm{dBrU}$ ) photolysis, UV-endonuclease sensitive sites and dimer chromatography. Inhibitors of DNA synthesis [hydroxyurea (HU) and cytosine arabinoside (ara-C)] also have an effect on the excision repair of pyrimidine dimers. Repair processes for UV-induced DNA dawage may provide a model for the study of DNA damage by chemical and by other physical agents which result in mutagenesis and carcinogenesis in mammalian cells.

HU is most often used for the selective suppression of replicative DNA synthesis. Repair synthesis, elicited by the excision of DNA damage, is more easily detucted under these conditions. However, HU in some instances interferes with the excision repair process. We have compared the effects of HU on the excision of ultraviolet light induced pyrimidine dimers in unsynchronized human skin populations of growing cells and in cells outside of $S$ phase (quiescent populations). HU at low concentrations has little or no effect on the number of pyrimidine dimers excised from the DNA of normal human skin fibroblasts in a proliferating phase. The effect of HU on cells In a quiescent stage is quite different. HU at $2 \mathrm{mM}$ has a marked ef fect on the number of dimers excised while $10 \mathrm{mM}$ reduces excision by as much as $80 \%$. 
It is thought that the different response of these cells is due to the existence of different precursor pools. Cells undergoing excision repair In $S$ phase ay he a greater access to nucleotide pools than cells in non-S phase. Clearly, the growth phase must be taken into consideration in the evaluation of the effect of $H U$ on excision repair and its use in the measurement of repair replication.

We have evidence of the induction and repair of a $\mathrm{W}$-induced lesion in human cells which is apparently not a pyrimidine dimer. This observation was made by measuring strand breaks induced by $313 \mathrm{~nm}$ light in the DNA following UV $(254 \mathrm{~mm})$ irradiation. Immediately rollowing irradiation $\left(20 \mathrm{~J} / \mathrm{m}^{2}, 254 \mathrm{~mm}\right)$ of either normal, XP or XP-variant cells, about 2 breaks/ 109 daltons DNA can be induced by photolysis with $313 \mathrm{~nm}$ light. These breaks are not demonstrable $5 \mathrm{hr}$ after irradiation in normal cells; however, in XP-variant cells, the breaks are inducible for up to $24 \mathrm{hr}$ after irradiation. XP complementation group $A$ cells in the same $5 \mathrm{hr}$ period show an increase in the number of strand breaks seen with $313 \mathrm{~nm}$ light photolysis to about 4 breaks $/ 10^{9}$ daltons DNA which can be induced for up to $24 \mathrm{hr}$. These data indicate that in normal cells the lesion responsible for this effect is rapidly repaired or altered, whereas in XP-variant cel1s it seems to remain unchanged. Some change apparently occurs in the DNA of XP group A cells which results in an increase in photolability. These data may, thusly, indicate a deficiency in DNA repair of XP-variant cells as well as in XP group A cells. Pyrimidine dimers are probably not responsible since our assays indicate the XP-variant cells repair these lestons in thelr DNA as well as normal cells.

Ir. addition to dimer chromatography and dBrU photolysis, we have developed other assays of repalr which ald in the study of repair kinetics In different cell 11nes. One useful assay involves the inhibition of repair by ara-C and the combination of ara-C and $\mathrm{HU}$ (ara-C/HU). This assay was used for comparative studies of UV-induced DNA repair and Its Inhibition by these compounds in log phase and confluent cell cultures of normal and XP-variant human skin fibroblasts. Repalr inhibition was determined by measuring the accumulation of DNA single-strand breaks following cell culture exposure to ara-C or ara-C/HU in a series of $3 \mathrm{hr}$ pulses up to $24 \mathrm{hr}$ after UV 1nsult. Normal and XP-variant cells showed a wide range of sensitivity to both ara-C or ara-C/HU in $10 g$ phase cultures. The amount of repair inhibition observed was inversely proportional to the generation time of the cells. In confluent cultures, maximum repair inhibition was observed with ara-C/HU in both normal and XP-variant cultures. The maximal level of repalr inhibition was observed in normal cells after recelving ara-C alone after $U V$, but was 62-68\% lower in $X P$-varlant cells recelving ara-C vs ara-C/HU. Repalr arrest was more rapidly reversed by fncreasing concentrations of exogenous deoxycytidine added in combination with ara-C in XP-variant compared to normal cells, especially in confluent cultures. With ara-C/HU, the level of repair Inhibition was reduced to a lower degree in the XP-variant when compared to cells exposed to ara-C alone. However, the same addition of $\mathrm{HU}$ had relatively little effect on dCyd competition in normal cells. Assay of dNTP pools by HPLC in the above cell lines suggested an elevated level of dCTP 
in the XP-variant lines during $\log$ phase, which is a possible explanation for lowered sensitivity to DNA repair inhibition by ara-C in the cells. The overall increase in dNTP pools in tbe XP-variant may be the result of defective DNA polymerase(s) which ultimately leads to error-prone repair.

The $\mathrm{dBrU}$ photolysis assay has proven to be useful in monitoring the effects of products of coal conversion (liquifaction and gasification) on DNA in human cells. This repair assay is capable of detecting, in addition to danage-induced DNA repair, agent induced photolysis which produces DNA strand breaks and DNA cross-linking. Results such as these are of interest since they indicate unrepaired DNA damage.

An array of products from steps in the H-coal liquifaction process was assayed for ability to induce DNA damage. These samples included crude samples taken at different steps of successive hydrogenation (hydrotreatment or HDT) and samples resulting from fractionation of a crude fuel ofl sample (provided by the Analytical Chemistry Division, ORNL), including aliphatic, mono/diaromatic and polyaromatic fractions. No significant level of DNA repair was detected in any of the samples tested. However, the presence of photosensitive lesions was noted in almost every sample assayed. Successive hydrogenation steps in the HDT series of samples resulted in fewer DNA strand breaks/108 daltons DNA induced by $313 \mathrm{~nm}$ light - suggestive of less DNA damage. The aliphatic fraction of crude ofl caused significant photolytic damage ( 1.09 strand breaks $/ 10^{8}$ daltons DNA), while the polyaromatic fraction caused extensive DNA cross-linking to occur. The overall results point out potential hazards to personnel who deal directly with coal liqufaction products and further suggests that successive hydrotreatment steps significantly reduce the mutagenic/ carcinogenic potential of the final products of $\mathrm{H}$-coal liqufaction.

Benzola]pyrene a ubiquitous environmental pollutant, when metabolized to Its active metabolite, benzola]pyrene diol epoxide (BPDE), has been shown to be highly mutagenic and carcinogenic. Several stereoisomeric forms of BPDE with varying amounts of blological activity are produced during the activation process. Recently we have studied the induction of DNA damage and its repair in human cells by two diastereomeric forms of $B P D E$, namely the potently carcinogenic anti- and non-carcinogenic syn-BPDE. Interestingly enough, we have found the anti-isomer to induce two-fold more DNA adducts, yet induce simllar amounts or slightly less repair than the syn-1somer. These strand breaks occur at a much reduced frequency in XP cells, which carry a genetic defect rendering them incapable of DNA excision epair. These differences in repair may correlate with the mutagenic and carcinogenic properties of thase two isomeric forms of BPDE. In addition we have examined the size of the repalr patch produced during the repali of these two DNA-adducts, and have found both to induce a long patch repair with approximately 40 nucleotides being inserted per repaired lesion.

Several classes of compounds exist which inhibit individual steps or the entire process of DNA excision repair. Using specific acting inhibitors we can dissect out individual molecular events induced in the 
DNA excision pathway. To this end we have recently examined the effects of aphidicolin, a specific competitive inhibitor with deoxycytidine triphosphate for DNA polywerase alpha, UV-Induced DNA excision repair. Three major DNA polymerase species exist in the human cell, with DNA polymerase alpha being in highest concentratior. We have found aphidicolin to inhibit both the resynthesis step and the excision step following UV-induced repair, thus implicating a mor role for DNA polymerase alpha in human DNA excision repair. This inhibition is dependent on the metabolic state of the cells. Cells which are undergoing rapid growth and division are relatively resistant to aphidicolin, while cells which are in a quiescent monolayer are quite sensitive to the inhibitory action of aphidicolin. We have found it takes a concentration of aphidicolin 100-fold higher to inhibit repair in rapidly proliferating cells to the same extent as in nondividing cultures. These differences in inhibition are due to at least two factors, the size of the deoxynucleotide pools and the levels of DNA polymerase alpha in human cells. Rapidly proliferating cells have elevated levels of deoxynucleotides and DNA polymerase alpha thus rendering them relatively insensitive to the drug. Using specific acting inhibitors like aphidicolin we have shown how various metabolic states of the cell can modulate the repair response to DNA damage.

The biclogical relevance of induction and repair of DNA damage should properly emerge from a correlation of such damage and repair with (i) mutation, (ii) cell killing, and (iii) environmental carcinogenesis. It is encouraging that some correlations have been made and are consistent with the idea that more DNA damage and/or less repair lead to more mutation and cell killing. With regard to correlation of DNA damage and repair, and environmental carcinogenesis, the problem is more complex in that experimental carcinogensis is properly studied in the whole animal while DNA repalr experiments are most conveniently done using cells in culture.

It is hoped that continued studies on the control of cellular processes involved in DNA damage and its repair, detalled kinetic analysis and correlations between biochemical events and changes in cell growth will lead to understanding and subsequent control of carcinogenesis.

1. Collier, I. E., Olson, H. H., Regan, J. D., A mechanism for the control of patch size in mammalian cell DNA excision repair. J. Theoret. Biol. 102: 487-499, 1983.

2. F zgan, J. D., Snyder, R. D., Prancis, A. A., 01la, B. L., Excision repair of ultraviolet and chemically induced damage in the DNA of fibroblasts derived from two closely related species of marine fishes. Aquat. Toxicol. 4: 181-188, 1983.

3. Snyder, R. D., Regan, J. D., Studies on the inhibition of repair by ultraviolet - and methyl-methane sulfonate-induced damage in the DNA of human fibroblasts by novobicin. Nucl. Acids. Res. 10: 6207-6219, 1982. 
GENETIC ANALYSIS OF DNA REPAIR IN MAN WITH CELL HYBRIDS

\author{
J. D. Regan \\ P. A. Lalley \\ W. C. Dunn, Jr. \\ B. E. Allen \\ A. A. Francis
}

The long-range goal of this project is to investigate the expression and Individual genetic components involved in the repair of DNA damage and to localize the genes involved in this complex system to specific human chromosomes. Such an elucidation of the genetic basis for the repair of DNA damage caused by physical or chemical agents is fundamental if we are to understand its pivotal role in carcinogenesis and mutagenesis. We have employed man $x$ mouse somatic cell hybrids as our experimental system and bromodeoxyuridine photolysis, radiochromatography and molecular weight analysis as our assays for DNA repalr to pr.rsue this project. The use of somatic cell hybrids allows for the mapping of genes to specific human chromosomes and the genetic dissection of this polygenic system due to the Is -otion of its component parts as a result of the preferential segrega$\therefore \therefore$.: of human chromosomes in proliferating human $x$ mouse somatic cell hybritis.

The mechanisms by which cells repair induced DNA damage play a central role in carcinogenesis such that deficient or inaccurate repair could result in carcinogenesis. The most direct evidence for this is derived from the existence of the recessively inherited human disorder xeroderma pigmentosum (XP) in which there has been a direct linkage between deficient repair of UV-induced DNA damage and indication of cancer. The genetic heterogeneity in XP, as reflected in the existence of at least seven complementation groups, Indicated that a greater understanding of the genetic structure of the DNA repair system is required if xeroderma pigmentosum is to be fully utilized as a model system for studying radiation induced carcinogenesis. To analyze the genetic structure of excision repair in man, human $x$ mouse somatic cell hybrids were employed. The preferential segregation of human chromosomes in proliferating hybrid cells and the ability to specifically identify each chromosome make it possible to dissect this complex polygenic system by isolating its component parts and to determine the chromosomal assignment of genes required for the repair of UV-Induced DNA damage.

Human $x$ mouse somatic cell hybrid clones, lsolated from five separate fusion experiments employing human cells derived from inrelated individuals normal for repair of UV-DNA damage, were analyzed for repair ability employing the bromodeoxyuridine photolysis assay. Mouse cells repair UV-induced DNA damage at 5-10\% of the magnitude of human cells. Therefore, it was possible to distinguish quantitatively human and mouse DNA repair components in cell hybrids. The repalr abllity of hybrid clones falls into one of three categorles: (1) those having human-like repalr; (2) chose having mouse-like repair; and (3) hybrids intermediate between the two. Data derlved from experiments which measure the Induction of $M$. luteus edonuclease sensitive sites following UV irradiation indicate that the number of dimers/10 8 daltons induced in human, mouse, and human $x$ mouse 
cell hybrids is the same. Therefore, the difference in repair capabilities observed in hybrid cells by $\mathrm{dBr} U$ photolysis is due to retention or loss of specific human genes due to human chromosome segregation by the hybrid cells.

The man $x$ mouse somatic cell hybrids were analyzed for the presence or absence of each human chromosome. When the segregation of the ability to repair UV-induced DNA damage was compared to the segregation of human chromosomes in three sets of hybrids made between human fibroblasts and mouse cells there was a strong correlation $r$-tween the presence of human chromosome 3 and the ability to repair UV-induced DNA camage and the loss of chromosome 3 and the loss of excision repair capacity. These data suggest that a gene or genes required for DNA repair is located on chromosome 3. In these same clones there was a correlation betwcen chromosome 14 and excision repair capacity. It is interesting to note in this regard that aberrations of chromosomes 3 and 14 have been associated with specific human malignancier, suggesting a possible association between disturbances of the repair syslem and carcinogenesis.

GENETIC DISSECTION OF DNA REPAIR IN XERODERMA PIGMENTOSUM CELLS

$\begin{array}{ll}\text { P. A. Lalley } & \text { W. C. Dunn, Jr. } \\ \text { J. A. Diaz } & \text { A. A. Francis } \\ \text { J. D. Regan } & \end{array}$

The humar skin disease, xeroderma pigmentosum (XP), demonstrates direct linkage between defective repair of damaged DNA, induction of mutations and induction of cancers. Studies utilizing the fusion of XP cells from unrelated patients have indicated that excision cefective cells can be classified into at least seven different complementation groups designated A through $G$. This genetic heterogeneity in XP is perplexing since the biochemical lesion is thought to be in the UV endonuclease which initiates excistion of UV-induced pyrimidine dimers in DNA. An elucidation of the basis for the genetic heterogeneity of XP is necessary if the functional relationships between DNA repair, mutagenesis, carcinogenesis, and risk assessment are to be fully understood and if xeroderma pigmentosum is to serve as a model system for such studies. Therefore, the specific objectives of this profect are to (a) determine the genetic basis of the heterogeneily in $\mathrm{vi}$ complementation groups; (b) determine the number of different genes which may be involved in the expression of the xeroderma pigmentosum phenotype; (c) determine the chromosomal location of the gene(s) responsible for XP; and (d) determine the specific genetic contilbution made by mouse cells to the XP cells which results in genetic complementation of their DNA repair capability. These studies were pursued using our ability to generate and genetically analyze man $x$ mouse somat:c cell hybrids for the presence of each human and mouse chromosome and the ability to repair DNA damage. The assays for DNA repair include (a) bromodeoxyuridine photolysis, (b) radiochromatography, and (c) molecular weight analysis. The use of somatic cell hybrids makes it possible to determine 
gene-chromosome assignments, to dissect this complex polygenic system by isolating its component parts and to investigate the genetic basis for complementation of defective repair in XP cells. To carry out these studies, several sets of hybrids were generated employing human parental cells derived from each of five XP complementation groups, namely Groups A-E. These human $x$ mouse cell hybrids were formed such that they either segregated human chromosomes and retained mouse chromsomes or segregated mouse chromosomes and retained human chromoscmes. Seven sets of hybrids were isolated from these fusion experiments.

When the XP $x$ mouse hybrid cells were analyzed for repair ability, it was found that mouse cells complemented the defective repair in four $X P$ complementation groups, namely Groups A, B, C, and D, but not in Group E, suggesting that the genetic defect in Group $E$ is different from that found in the other groups. Segregation analysis of the cell hybrids demonstrated that when XP $x$ mouse somatic cell hybrids segregated certain human chromosomes, they lost the ability to be complemented by the mouse cell. Presumably, these hybrids have lost the gene(s) coding for the repair step that is rate limiting in the mouse. On the other hand, the mouse supplies the repair step that is defective in the XP cell. In XP-A $x$ mouse hybrids, there is a strong correlation between the presence of chromosome 14 and the ability to be complemented and the loss if complementation and the loss of chromosome 14. No such correlation was seen with chromosome 3 . In XP-B $x$ mouse hybrids there is a correlation between the presence of chromosome 3 and complementation and absence of chromosome 3 and the loss of complementation. Chromosome 14 may also be associated with complementation since only one clone in the XP-B $x$ mouse hybrids was discordant for complementation and chromosome 14 .

Hybrids have also been generated between XP cells and mouse spleen cells under conditions which a. iow for the segregation of the mouse chromosomes and retention of the human chromosomes. These experiments were carried out to deterinine which mouse chromosomes carry genes involved in the complementation of the defective repair in XP. Data derived from XP-A $x$ mouse spleen cell hybrids suggest thai mouse chromosone 4 carries a repalr gene(s). However, our data cannot rule out other mouse chromosomes as possible sites for repair genes.

The complementation of defective repalr of UV ind ced DNA da rage in XP cells by mouse genetic material was shown to be biologicaliy significant. This was done by testing hybrid clones for resistance to UV irradiation. $X P$ cells are highly sensitive to UV irradiation. Using this approach viable XP $x$ mouse hybrid clones were isolated following UV irradiation, demonstrating that the XP defect had been complemented by mouse DNA both enzymatically and biologically. These findings provide the means for cloning mammalian repair genes and for studying DNA repair at the molecular lev?1. 
GENETIC BASIS OF MUTAGENESIS AND CARCINOGENESIS
P. A. Lalley
P. Braden
B. E. Allen
K. Moore ${ }^{I}$

The primiry objectives of this project are (I) to investigate the genes important for susceptibility to mutagens and carcinogens whether they be physical, chemical or biological agents; (2) to identify, characterize and determine the chromosomal assignment of these genes; and (3) to investigate the linkage relationships of homologous genes in man, mouse and other species. The data derived from these studies are important since an elucidation of the genetic basis of these systems is essential for the ultimate understanding of how genetic and environmental factors interact in the process of mutagenesis and carcinogenesis. Comparative mapping data are important for the extrapolation of biological and biomedical data from laboratory animals to man. These studies are being pursued utilizing somatic cell hybrids as our experimental system, which allows for the genetic dissection of complex polygenic traits by isolating their component parts, and the determination of gene-chromosomal assignments due to preferential chromosome segregation.

We have been investigating the genetics of the induction of the a:yl hydrocarbon hydroxylase system (AHH) In the mouse, a system of major importance in chemical carcinogenesis. The Ah locus encodes the receptor that controls the induction of aryl hydrocarbon (benzola]pyrene) hydroxylase (EC 1.14 .14 .1 ) by polycyclic hydrocarbons such as a benzo[a]anthracene or 3-methylcholanthrene. The hydroxylase inducibility by benzo[a]anthracene was studied in 29 somatic cell hybrid clones. In 2.8 of the 29 clones, the presence or absence of indicibility is associated with the presence or absence of mouse chromosome i7. Liver microsomal aryl hydrocarbon hydroxylase Induction by 3-methylcholanthrene or benzo[a]anthracene was also assessed in appropriate backcrosses with the Mus musculus molossinus, Mus musculus castaneus, MOR/Cv, $\mathrm{PL} / \mathrm{J}, \mathrm{SM} / \mathrm{J}$ and $\mathrm{DBA} / 2 \mathrm{~J}$ inbred strains and in 13 NX8 recombinant inbred lines. It was concluded from the studies that the presence of aryl hydrocarbon hydroxylase inducibility, i.e., the Ah locus encoding the receptor, is localized to the distal end of mouse chromosome 17, a chromosome which carries several genes (e.g. H-2 complex) which control the host response to foreign substances.

Treatment of mice with polycyclic aromatic hydrocarbins results in the Induction of cytochrome $P_{1}-450$ and $P_{3}-450$. The genes for both cytochromes have recently been cloned and shown to be coordinantly regulated by the Ah 1ocus. The mouse analogue of $P_{1}-450$ and $P_{1}-450$ can be distinguished from its hamster counterparts by Southern blot analysis with Kpn l restricted DNAs. DNA from hamster-mouse somatic cell hydids segregating mouse chromosomes were used in Southern blots to map the location of the two mouse genes. Chromosome segregation analysis of 12 hybrid clones demonstrated that the structural genes for both $P_{1}-450$ and $P_{3}-450$ are linked and can be assigned to mouse chromosome 9 and therefore are not linked to the gene which controls their expression, the Ah receptor locus on chromosome 17. These data are alding in our understanding of the 
control, expression and organization of the AHH system which is directly associated with chemical carcinogenesis.

The chromosomal locations of genes involved in murine viral carcinogenesis have been investigated utilizing restriction enzyme analysis with cDNA probes and somatic cell hybrids. In collaboration with Dr. W. K. Yang and $R$. W. Tennant we have investigated the genetics of the RF virus, an inducible marine leukemia virus from the RFM mouse. RFM/Un strain mice possess a single host range ( $\mathrm{N}$-tropic) class of endogenous retrovirus, which can be induced from virus negative cells in culture. We assayed virus induction in interspecific hybrid clones of RFM spleen or bone marrow ceils and Chinese hamster (E36) cells that segregated mouse chromosomes. The data demonstrated that inducibility was controlled by a gene on chromosome 5. Independently, the hybrid clones were tested for endogenous murine retroviral sequences by restriction endonuclease digestion and electrophoresis-hybridization with a molecular cloned probe specific for ecotropic retroviruses. Virus inducibility was concordant with the presence of a $20 \mathrm{Kbp}$ band that was present onl, in clones retaining chromosome 5 indicating that the $R F$ virus sequences are integrated on chromosome 5. These results make it possible to identify novel rearrangements of this endogenous virus in rells with different neoplastic phenotypes. We belleve that the data derived from these studies will heip to make the RFM/Un mouse strain a valuable model system in which to study the relationships between radiogenic myelofd leukemia, specific chromosomal rearrangements and retrovirus genes.

Mati, mouse and all mammalian species studied possess normal cellular genes (proto-oncogenes) homologous with acutely transforming retrovirus oncogenes. Recently altered forms of several proto-oncogenes have been identified in malignant cells. These data have fostered speculation of possible roles of proto-oncogenes in malignant transformation of cells and prompted the investigation of their chromosomal assignments. Since consistent numerical and structural chromosome abnormalities have been associated with a number of different cancers, it is possible that protooncogenes might reside at chromosome breakpoints associated with specific tumors, We have pursued these si:udies by screening somatic cell hybrids with 32p-labeled viral oncogene probes. A molecular clone of viral myc( $v-$ myc), the oncogene of avian myelocytomatosis virus MC29 detected homologous human, mouse, and Chinese hamster cellular myc(c-myc) sequences by Southern filter hybridization. Using human $x$ mouse somatic cell hybrids we demonstrated that the human c-myc is located on human chromosome 8 close to the breakpoint on chromosome $8(q 24)$ involved in the $t(8 ; 14)$ translocation found in Burkitt's lymphoma. The mouse $c$ myc gene was shown to be located on mouse chromosome 15 in a region involved in the $t(15 ; 12)$ translocation associated with mouse plasmacytomas. In addition, in collaboration with Leroy Hood and colleagues at the California Institute of Technology, it was demonstrated that this region of mouse chromosome 15 contains a DNA sequence termed NIRD (non-immunoglobulin rearranged DNA) which is also rearranged in mouse plasmacytomas. In both the $t(8 ; 14)$ in man and the $t(15 ; 12)$ in the mouse the myc gene 18 translocated into a chromosomal region involved in immunoglobulin production. These gene assignments are noteworthy becaus: the myc gene is located in homologous 
chromosomal regions in both man and mouse which are involved in structural abnormalities associated with homologous B-cell neoplasms. Following the same approach we have assigned $f$ ive additional mouse proto--oncogenes using DNAs of 15 mouse-Chinese hamster somatic cell hybrids which were screened with 32 p-labeled viral oncogene probes. We assigned a mouse c-8rc gene to chromosome 2, c-Ki-ras to 6, c-Ha-ras to 7, c-nyb- to 10 , and c-erb-a to

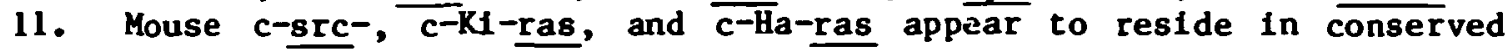
linkage groups In mouse and man; for example, c-src is on human chromosome 20 (with ADA and ITP homologous to mouse chromosome 2), c-Ki-ras 2 is on 12p (with TPI and GAPD homologous to mouse chromosome 6), and $\overline{c-H a}-r a s$ is on IIP (with INS, $\mathrm{HBB}$, and LDHA homologous to mouse chromosome 7). It has been reported that a deletion commonly encompassing bands $C-\Gamma$ of mouse chromosome 2 is found in $94 \%$ of myeloid leukemias. Whether these deletions affect the c-src gene or the c-abl gene, which are both iocated on chromosome 2, 1s not presently known. In man the c-abl gene is located in a region on chromosome 9 involved in a reciprocal $t(9 ; 22)$ translocation assoclated with chronic myelold leukemia. Rearrangements of mouse $c$ myb and altered c-myb mRNA transcripts have been observed by others in mouse plasmacytold lymphosarcomas. Whether the alterations in c-myb arise by intra- or inter-chromssomal events is not known. These assignments should be useful in assessing the significance of chromosome rearrangements in murine neoplasms.

We have continued to combine the use of somatic cell hybrids with recombinant DNA techniques to map genas coding for proteins which are not expressed in tissue culture cells.

The interferons have been classified as $\alpha, \beta$, and $\gamma$ (or leukocyte fibroblasts and immune) on the basis of biological, biochemical, and antigenic properties. The human interferons have been cloned and characterized quite extensively genetically. Recently, a cDNA clone specific for mouse Immune interferon (IFN- $\gamma$ ) was isolated. We used this clone containing a 638 bp insert to detect mouse interferon sequences in mouse-Chinese hamster hybrids segregating mouse chromosomes. Mouse DNA digested with EcoRI and probed with mouse IFN- $\gamma$ CDNA in a Southern filter analysis contains a single $18 \mathrm{~kb}$ HindIII Fragment which anneals with the probe. In contrast, Chinese hamster DNA does not hybridize to the cDNA. Th1s $18 \mathrm{~kb}$ fragment segregated in 15 mouse-Chinese hamster hybrids depending on the mouse chromosome composition. This segregation pattern indicated that the mouse immune interferon gene ( $\mathrm{Ifg}_{\mathrm{g}}$ ) is located on chromosome 10 . It is interesting to note that the human immune interferon maps to chromosome 12 $(p 12+q t e r)$. This region of chromosome 12 also contains the genes for peptidase-2 (B) and acetate synthetase. The homologous genes in mouse are also located on chromosome 10 , suggesting that this is a conserved linkage group between man and monse.

Nerve growth factor (NGH, also referred to as the BNGF) is a protein essential for neuron development. High levels of NGF activity are expressed in the adult male mouse submaxillary gland. A $1.1 \mathrm{~kb}$ cDNA from this tissue encoding the mouse NGF precursor (prepro NGF) was used to chromosomally assign the mouse $\mathrm{Ngf}$ gene by the methodologies described above. The cDNA probe hybridized to $15 \mathrm{~kb}$ and $7 \mathrm{~kb}$ fragments of BALB/c 
mouse DNA cleaved with HindIII, whereas HindIII cleaved Chinese hamster DNA yielded $14 \mathrm{~kb}$ and $5.5 \mathrm{~kb}$ hybridizing fragments. DNAs from 15 mouseChinese hamster cell hybrids were isolated and hybridized to the NGF probe. Mouse Ngf segregated concordantly only with mouse chromosome 3. This segregation pattern was identical to that of mouse amylase when these cell hybrid DNAs were annealed with a rat amylase probe. Mouse amylase (Amy-1, Amy-2) is known to be on mouse chromosome 3. The data suggest that mouse $\overline{A m y-1}$, Ang-2, and Ngf reside in a conserved linkage group, as the human AMY1, AMY2, and NGF are all located on the short arm of chromosome 1 .

The genes for the serine endopeptidase chromtrypsinogen $B$ (Ctrb), elastase-1 (Ela-1), and trypsin-1 (Trp-1), and the exopeptidase carboxypeptidase A (Cpa), have been isolated from a rat cDNA library. In order to map these genes in the mouse, DNA from mouse $x$ Chinese hamster hybrids was cleaved with HindIII or Bam HI and hybridized to Ctrb, Ela-1, Trp-1, or Cpa cDNA probes. Mouse Ctrb gene sequences, detected on $5.3 \mathrm{~kb}$ and $3.1 \mathrm{~kb}$ fragments, segregated only with chromosome 8. Mouse Ela-1 gene sequences detected on $10 \mathrm{~kb}$ and $4.2 \mathrm{~kb}$ fragments, segregated only with chromosome 15 . Trp-1 gene sequences, detected on $12.8 \mathrm{~kb}, 9.2 \mathrm{~kb}$, and $6.56 \mathrm{~kb}$ fragments, and Cpa gene sequences, detected on $5.2 \mathrm{~kb}$ and $3.7 \mathrm{~kb}$ fragments, both segregated only with chromosome 6 . These data identify several conserved linkage groups. The human homolog of Ctrb maps to human chromosome (HSA) 16 and therefore comprises part of the region of homology previously observed between mouse chromosome (MMU) 8 and HSAl6. We have mapped the human homologs of both $\operatorname{Trp}-1$ and Cpa to HSA 7q22+qter and thus a region of homology exists between $\overline{\mathrm{MUU} 6}$ and $\widehat{\mathrm{HSA7}} \mathrm{q}$.

The chromosomal locations of the genes for the common $\alpha$ subunit of the glycoprotein hormones and the $\alpha$ subunit of chorionic gonadotropin in mice and humans have been determined by restriction enzyme analysis of DNA isolated from sumatic cell hybrids. The CG a gene (CGA), detected as a $15 \mathrm{~kb}$ BamHI fragment in human DNA hybridization to CGac DNA, segregated witn the chromosome 6 enzyme markers MEI (Mallc enzyme, soluble) and SOD2 (suoperoxide dismutase, mitchondtral) and an intact chromosome 6 in humanrodent hybrids. Cell hybrids containing portions of chromosome 6 allowed for the localization of CGA to the $q 12-q 21$ region. The 30 and $6.5 \mathrm{~kb}$ BamHI CGB fragments hybridizing to human CG $\beta$ CDNA segregated concordantly with the human chromosome 19 marker enzymes PEPD (peptidase D) and GPI (g]ucose phosphate 1somerase) and a normal chromosome 19 in karyotyped hybrids. A KpnI-HIndIII digest of celi hybrid DNAs indicated that the multiple copies of the CGB gene are all located on human chromosomn 19. In the mouse, the $\alpha$ subunit gene, detected by a mouse thyrotropin (TSH) $\alpha$ subunit probe, and the CGB-LHB gene, detected by the human CG $\beta$ CDNA probe, are on chromosomes 4 and 7 , respectively. Lhb appears as though it may lie in a conserved region since chromosome $\overline{7}$ also carries the genes for glucose phosphate 1somerase and peptidase-4 whose homologous genes as well as the LHB gene are on human chromosome 19.

Humans show a single insulin protein and gene while mice and rats possess two distinct insulins. To determine the chromosomal location of the mouse insulin genes we have examinud Chinese hamster $x$ mouse somatic cell hybrids segregating mouse chromosomes by restriction enzyme analysis 
with a mouse specific cDNA probe for the insulin gene. The data demonstrate that the mouse carries a total of three insulins located on three different chromosomes: 6,7 and 15 . The insulin gene located on chromosome $?$ has been partially sequenced and these data indicate that this gene codes for Insulin II protein and appears to be homologous to the human and rat II insulin genes. In man the homo'ogous insulin gene (INS) has been assigned to chromosome $11 \mathrm{p}$ and is syutenic with LDHA and HBB. In the mouse the homologous genes are also located on chromosome 7 indicating that a region of human chromosome 7 is homologous to a region of human chromosome 11p. The functions of the other two insulin geues on chromosome 6 and 15 are not known. However, one should code for insulin I while the other may be a pseudo-gene. These data demonstrate that evolution of the insulin proteins has proceeded differently in rodents and man. This has implications for extrapolation of data from laboratory animals to man when dealing with systems that have genetic components.

To further our understanding of the evolution of the mammalian genome we have initiated gene mapping experiments in nonhuman primatea. To determine which linkage gioups have been conserved between man and the more distantly related primates, namely the Cercopithecoidea, somatic cell hybrids were formed between mouse cells and baboon (Papio papio) lung fibroblasts derived from two unrelated baboons. Thirty-two primary clones segregating baboon chromosomes were analyzed for the expression of 25 gene markers. In particular, genes assigned to human chromosomee 4, 6, 14,15 , and 20 were studied. Data derived from these studies demonstrated that the genes coding for phosphoglucomutase 2 (PGM2) and peptidase $S$ (PEPS) are syntenic. These data indicate that the ptertq12 region of human chromosome 4 (HSA4), is homologous to a region of baboon chromosome 5 (PPA5). Our dat.a further demonstrated that the gene coding for the mitochondrial form of superoxide dismutase (SOD2) segregated concordantly with malic enzyme (MEI) and glyoxylase (GLO) indicating that the linkage group of MEI-GLOSOD2 is conserved between man and baboon. The concordant segregation of inosine triphosphatase (ITP) and adenosine deaminase (ADA) in these hybrids demonstrates that ITP and ADA are syntentc, indicating that PPAIO is homologous to HSA20. In addition, data derived from these studies conf $1 \mathrm{rm}$ that the genes coding for mannosephosphate 1somerase (MPI), pyruvate kinase 3 (PK3) and nucleoside phosphorylase (NP) are syntenic in the baboon, indicating that regions of PPA 7 are homologous to HSA 14 sid 15 .

1. Calame, K., Kim, S., Lalley, P., Hill, R., Davis, M., Hood, L., Molecular cloning of trarilocations involving chromosome 15 and the immunogloubulin $C \alpha$ gene from chromosome 12 in two murine plasmacytomas. Proc. Nat1. Acad. Sc1. ULA 79: 6994-6998, 1982.

2. Naylor, S. L., ChIn, W. W., Goodman, H. M., Lalley, P. A., Grzech1k, K. H., Sakaguchi, A. Y., Chromosome assignment of the genes encoding the $\alpha$ and $\beta$ subunits of glycoprotein hormones in man and mouse. Somatic Cell Genet., in press.

3. Roderick, T. H., Pearson, P. L., Davisson, M. T., Lalley, P. A., O'Bifen, 5. J., Report of the committee a:t comparative mapping. Cytogenet. Cell Genet. 32: 208-221, 1982. 
4. Sakaguchi, A. Y., Lalley, P. A., Naylor, S. L., Human and mouse cellular yyc protooncogenes reside on chromosomes involved in numerical and structural aberrations in cancer. Somatic Cell Genet. 9: $391-405,1983$.

5. Sakaguchi; A. Y., Lalley, P. A., Zabel, B. U., Ellis, R. W., Scolnick, E. M., S. L. Naylor, Chromosome assignments of four mouse cellular homologs of sarcoma and leukemia virus oncogenes. Proc. Nat. Acad. Sci. USA, in press.

6. Tennant, R. W., Boone, L. R., Lalley, P. A., Yang, W. K., Endogenous retrovirus and radiation-induced leukemia in the RFM mouse. Prog. Nucleic Acid Res. Mol. Biol, 29: 75-86, 1983.

8. Tennant, R. W., Lalley, P. A., Diaz, J. A., Otten, J. Yang, W. K., Chromosome 5 contains the inducible ecotropic retroviral locus of $\mathrm{RFM} /$ Un mice. J. Virol., in press.

\section{MAMMALIAN BIOCHEMICAL GENETICS}

$$
\text { R. A. Popp D. M. Popp }
$$

The principal aim of our studies is to evaluate hazards to humans of exposure to nuclear and chemical by-products of energy producticn. Mice are used as experimental animals but the data obtained are analyzed with respect to potential hazards to man. The studies can be divided into the four general areas of research discussed below.

Mechanisms of Mutations Induced in Germinal Cells by Irradiation and Chemizals. We have continued to study the expression of hemoglobin genes ir progeny of mice exposed to mutagens. Last year we reported on an ethylnitrosourea induced $A \rightarrow T$ transversion at the codon for position 89 (CAC $\rightarrow$ CTC) of an alpha-globin gene, which resulted in an amino acid substitution (His $\rightarrow$ Leu). This mutation has not been observed previously in humans, mfce or othe: mammals, and its novel occurrence may be indicative of other unusual mutational events that do not ordinarily occur in the absence of specific mutagen exposice.

We are presently analyzing an ethylnitrosourea induced mutation at the compound beta globin ( $\mathrm{Hbb}$ ) locus. The mutation changes the electrophoretic mobility of the majority of the beta-globin polypeptide controlled by the $\mathrm{Hbb}^{8}$ allele. The specific nature of this mutation 18 under investigation but it is likely that the electrophoretic moblilty change is caused by the substitution of a single amino acid resulting from an ethylnitrosourea induced substitution of a single base in the DNA. Definition of the precise base substitution involved will add to our data base of specific mutations induced by cheinicals such as ethylnitrosourea. As additional induced mutations are characterized, comparisons between newly induced and naturally occurring mutations in the mouse may provide insight into potential genetic hazards to which man may be subfected from exposure to mutagens in the environment. 
The proband bearing the newly discovered wutation of the Hbbs allele was a feale. Upon electrophoresis her henoglobin gave an unusual fourbanded pattern and the quantitative analysis of the four hemoglobins in the proband was different fron that in her progeny that also exhibited four electrophoretically distinguishable hemoglobins. Genetic studies established that the proband was a germinal mosaic; her cva contained either the noral or the nutant beta-globin genes. The unusual quantitative analysis of the Individual hemoglobins in the proband can be explained on the basis that she is also a somatic cell mosaic and her red cells express efther the norval or the mutant beta-globin genes. It has been possible to establish a colony of mice with this ethylnitrosourea induced mutation because the mutation was expressed in some of the germinal cells. We had previously found an $X$-ray-induced beta-globin wutation that was expressed only in somatic cells ( 3695 ) but we were not able to establish a colony of mice with that $\mathrm{X}$-ray-induced mutation.

In July of 1982, Dr. Susan Lewis (Research Triangle Institute) discovered a DBA/2J mouse in which the ratio of beta-major/beta-minor hemoglobin, usually $80 / 20$, was shifted to 55/45. Homozygotes for this mutation produced only the beta-minor polypeptide - no beta-major polypeptide was produced. The molecular basis for the faslure of the beta-major polypeptide synthesis was revealed through Southern blot analysis of DNA, which showed that a $3.3 \mathrm{kilobase}$ segment of DNA, including the beta-major gene, was missing in homozygotes. This mutation arose spontaneously and the exact nucleotide sequences surrounding both ends of the deletion are being analyzed. Mice homozygous for this spontaneous deletion exhibit symptoms of beta-thalassemia, which is a severe genetic disease in man. The line of milce established from this mutant represents the only animal model of this disabling disease.

Genetic Regulation of Gene Expression and the Organization of Genetic Information. The studies mentioned above indicate that a fundamencal understanding of the structure, function, organization, and regulation of genes and their products was exsential tu interpret the mechanisms of the spontaneous beta-thalassemia mutation and the X-ray- and ethylnitrosoureainduced mutants at the alpha- and beta-globin gener. We reported last year that transcription of the alpha-globin genes we. ilevated to $75 \%$ of normal and partially compensated for the loss of one-alf of the alpha-globin genes in alpha-thalassemic mice. A similar but more dramatic compensation appears to occur in beta-thalassemic mice. The Hbbd beta-minor globin gene controls the synthesis of 3 picograms of beta globin per irythrocyte in normal mice but 10 plcograms of beta globin are produced in erythrocytes of beta-thalassemic mice. Our previous studies in mice have shown triat the synthesis of alpha- and beta-globins exactly reflects the quantities of alpha- and beta-globin mRNAs. Thus, it would appear that transcripition of the beta-minor globin gene in beta-thalassemic mice is three-fold that in normal mice. Possible mechanisms for this three-fold increase in the level of beta-minor globin gene transcription are teing investigated. Elucidation of such mechanisms should help us to understand better how specific genes are regulated during development and cell differentiation and, by inference, what may go wron! during abnormal growth and differentiation of tumor cells. 
The newly found, ethylnitrosourea induced mutation at the compound ubb locus is being used in our studies on the genetic regulation of hemoglobin gene expression. Mice of the $\mathrm{Hbb}^{\mathrm{s}} / \mathrm{Hbb}^{\mathrm{S}}$ genotype produce only one kind of beta-globin polypeptide even though they possess two beta-globin genes, called betas and bet $a^{t}$. The betas and betat genes can be recognized by using Soutinern blotting technfques but their gene products - mRNAs and beta-globin polypeptides - cannot be distinguished by mRNA/cDNA hybridization and amino acid sequencing. Thus, it was not known whether or not both bet $^{s}$ and betat genes were functional and, if both functioned, whether the levels of expression of these two genes differed in a manner comparable to the differential expression $(80 / 20)$ of the beta-major/beta-minor globin genes, respectively, of the $\mathrm{Hbb}^{\mathrm{d}}$ allele. Mice homozygous for the ethylnitrosourea induced mutation of the Hbbs $^{s}$ allele produce two electrophoretically distinguishable beta-globin polypeptides; the product of the mutant's $\mathrm{Hbb}^{\mathbf{S}}$ gene represents about 75 percent of the total beta-globin. Thus, we now know that both beta-globin genes of mice of the $\mathrm{Hbb}^{\mathrm{s}} / \mathrm{Hbb}^{\mathrm{s}}$ genotype are active and that the level of expression of one gene is higher than the other. Studies are in progress to determine whether betas and betat of the $\mathrm{Hbb}^{\mathrm{s}}$ allele are homologous to the beta-diffuse-major and the beta-diffuse-minor genes of the $\mathrm{Hbb}^{\mathrm{d}}$ allele as regards both the organization and the structure of these genes on chromosome 7 of mice.

Pathophysiological Effects of Induced Mutations. We have previously reported on the clinical symptoms (anemia, splenomegaly and iron overloading) in mice heterozygous for alpha-thalassemia, and on the embryonic lethality in mice homozygous enr alpha-thalassema. In humans the clinical symptoms of beta-thalassemia are severe; humans homozygous for betathalassemia die unless supportive blood ransfusions are given regularly. In cortrast, mice homozygous for beta-thalassemia survive even though they are very anemic at birth and are easily recognized by their paler appearance. Adult beta-thalassemfc mice have lower than normal hematocrit and hemoglobin values and elevated reticulocyte counts; their red cells are microcytic and exhibit anisocytosis. The synthesis of alpha- and betaglobin polypeptides has been measured using $3_{\mathrm{H}-\mathrm{l} \text {.eu incorporation; the }}$ synthesis of beta-globin is about $70 \%$ of normal. In spite of these severe clinical symptoms, both male and female homozygotes are able to breed and females raise their young. A few homozygous beta-thalassems $r$ mice have been sacrificed for gross inspection. Splenomegaly (four- to ten-fold normal size) is obvious. The population of mice is being enlarged :0 initiate thorough studies on the pathophysiological effects of this mutation. These mice are the only animal models of beta-thalassemia; until now beta-thalassemia has been exclusively a human disease. These mice will be valuable experimental animals for studies on the progression of symptoms associated with human beta-thalassemia and in our attempts to do gene therapy to correct this genet: defect.

In Vivo Studies on the Toxiclty and Mutagenicity of Ethylene Oxide. We explained last year why we use the hematopoetic system to study the In vivo toxic and mutagenic effects of chemicals, drugs and environmental $\overline{p c l}$ lutants. Briefly, the number of pluripotent stem cells can be quantifled (CFU-S), the effects on undifferentiated stem cells and more differentiated cell populations can be assayed, changes in cell cycle 
parameters can be analyzed by measuring the DNA content of cells by flow cytometry, and the number of 6-thioguanine resistant (putative mutant) CrU-S induced by a chemical can be quantified. In collaboration with R. Mann and R. Hand (Biology Division) flow cytometric analysis on the Ortho $50 \mathrm{H}$ has been modified to characterize specific cell types in the heterogeneous population of cells in bone marrow. Forward and $90^{\circ}$ light scattering are being used to identify cells of different sizes and worphology, respectively, and fluorescence is being used to identify cells with specific cell surface markers (fluorescein-labeled anti- $\mu$ heavy chain) and to quantify changes in DNA content (propidium lodide). By using a conbination of these techniques, we have been able to identify and enumerate separate cell populations in normal bone marrow. The above techniques and other tests developed in our laboratory and described last year have been used to study the effects of ethylene oxide on the hematopoietic system of mice. Mice were exposed by inhalation to $255 \mathrm{ppm}$ of ethylene oxide for $6 \mathrm{hr}$ per day for $2,4,6,8$ and 10 consecut lve days in a preliminary study done with R. B. Cumming (Biology Division) and for $1,2,4,8,10$ and 14 consecutive days or for $4, \therefore, 8$ and 10 weeks (5 days per week, $6 \mathrm{hr}$ per day) in the second experiment done with Simon Lock (Biology Division). Analysis of peripheral blood and bone marrow showed that marked perturbations occurred beginning after the first 6 hours of exposure to ethylene oxide. Red cell, white cell, bone marrow cellularity and CFU-S values were all depressed. The red blood cell counts and hematocrits were slightly but continuously depressed throughout the period of exposure. The white blood coints showed pertodic shifts toward normal beginning at four days but were as low as $35 \%$ of normal after 8 weeks of exposure to ethylene oxide. The peripheral leukocytes showed the greatest perturbation. A marked granulocytosis (200\% of normal) and a lymphopenia ( $25 \%$ of normal) were seen through day 4. The neutrophilia and lymphopenia continued over the 10-week exposure tc ethylene oxide. The highest granulocyte and luwest lymphocyte differentials occurred in mice with the lowest peripheral white blood cell counts. The numbers of monocytes and eosinophils also changed.

The bone marrow also showed severe perturbations after 1 day of exposure to ethylene oxide when the number of granulocytes was $76 \%$ of normal and the number of lymphocytes was $128 \%$ of normal. These values shifted even more after two days after exposure to ethylene oxide before an at tempt at recovery of homeostasis. However, the number of lymphocytes was then depressed below normal and the number of granulocytes fluctuated. The number of CPU-S remained below control values throughout the exposure to ethylene oxide; at 6 and 10 weeks the CFU-S in bone marrow was $70 \%$ of normal. The number of 6-thioguanine resistant CFU-S in the bone marrow of ethylene oxide exposed mice was not elevated above the control incidence; however, the bone marrow of the exposed mice was more sensitive to the 6-thioguanine used during selection for mutant cells.

The results of this study show that ethylene oxide was not highly toxic and it was not mutagenic under the conditions tested in vivo. However, ethylene oxide did cause a perturbation in bone marrow subpopulations and a homeostatic imbalance was continuous as long as the 
mice were exposed. The possible health effects of such a continuous homeostatic imbalance in the bone marrow has not been investigated.

1. Mann, R., Popp, D. M., Hand, Jr., R., The use of projection for dimensionality reduction of flow cytometric data. Flow Cytometry. submitted.

2. Popp, R. A., Bailiff, E. G., Skow, L. C., Johnson, F. M., Lewis, S. B., Analysis of a mouse alpha-globin gene mutation induced by ethylnitro.iourea. Genetics 105: 157-167, 1983.

3. Skow, L. C., Burkhart, B. A., Johnson, F. M., Popp, R. A., Popp, D. M., Goldburg, S. Z., Anderson, W. F., Barnett, L. B., Lewis, S. E., A mouse model for beta-thalassemia. Cell, in press.

4. Van Wyck, D. B., Popp, R. A., Foxley, J., Witte, M. H., Witte, C. L., Crosby, W. H., Spontaneous iron overload in alpha-thalassemic mice. Blood, in press.

5. Whitney III, J. B., Popp, R. A., Animal models of human disease: Thalassemia. Am. J. Pathol., in press.

\section{DROSOPHILA CYTOLOGY AND GENETICS}

\section{R. F. Grell E. E. Generoso}

Meiosis occupies the central position in eukaryotic genetics. It provides for the precise partitioning of the genetic material from the diploid to the haploid amount. Errors which occur in the process are nearly always deleterious and frequently lethal to the progeny. For this reason an understanding of the normal sequence of events is a prerequisite for evaluating the ways that chemical and physical agents can induce errors in the process. The principal melotic events are generally categorized as synapsis, recombination and segregation. The mechanisms of the former two, despite the critical role that they play in melosis, remain obscure aid controversial.

Studies completed last year demonstrated unequivocally that synapsis, in the case of the Drosophila oocyte, is incorrectly placed according to the conventional model of meloses. Rather than occurring during prophase, synapsis has begun early in premelotic interphase and homologues are paired throughout the premelotic-S phase. During the current year we have attempted to learn how great the requirement 18 for strict homology in the synaptic process. The presence of multiple inversions in one of a pair of homologues has long been recognized as an effective tool for eliminating crossover products. Such inverted chromosomes, called "balancers" are assumed to reduce exchange by causing pairing difficulties so that homologues are unable to align themselves properly for exchange. Cytological confirmation of pairing fallure at the ultrastructural level, however, has not been demonstrated. We are using the length of the synaptonemal complex as a measure of the amount of homologous synapsis. 
Our study utilizes females which carry mitiple inversions in each of the five chromosomal arms so that recombinant progeny are virtually eliminated. The iangths of the synaptonemal complex in melocytes with and without the heterozygous inversions, have been measured at four sequential timepoints during development using serially sectioned nuclei. Results show that the presence of the inversions causes a reduction in complex length of 45\%, 50\%, $48 \%$ and $45 \%$ for early pro-oocytes in a middle germarial cyst and for Stages 1,2 and 3 oocytes, respectively. These reductions are far short of expectation if synapsis were impaired throughout the genome :o the extent exchange results indicate. It may be that synaptic pairing 18 suffictently flexible to permit recognition of sequences located in nonidentical positions on homologues, as recently suggested by Goldberg et al. (Proc. Nat1. Acad Sc1. USA 80: 5017-5021, 1983) based on genetic grounds.

An examination of the first temperature-sensitive (ts) recombination mutant known in Drosophila and its two temperature-insensitive alleles has been completed. One method for characterizing mutants is through dosage studies. A leaky mutant is expected to cause gene expression to be more extreme with one dose than two, whereas a null mutant shows unaltered expression regardless of dose. The ts mutant, rec-1 26 behaves like a leaky mutant and shows 857 of normal expression in the hemizygote whereas its two alleles show no response to dose suggesting that they are null mutants. Examination of thermal response of ts rec- $1^{26}$ over a temperature range from $17^{\circ}$ to $31^{\circ} \mathrm{C}$ has revealed a straight line response with a slight negative slope between $17^{\circ}$ and $28^{\circ}$. A sharp drop off occurs between $29^{\circ}$ and $31^{\circ}$. A sharp drop within a narrow temperature range is typical of a denaturation curve. The results are interpreted as temperature denaturation of an enzyme or other protein produced by rec-1 26 , which is involved in the recombination process.

The ablifty to unfformly or nonuniformly reduce recombination along a chromosome arm has been used to partition melotic mutants into two functional types, the former involved directly with exchange and the latter with "preconditions" for exchange. The rec-1 ${ }^{26}$ mutant which shows a proximal directed polarity at $17^{\circ}$, reverses direction at $25^{\circ}$ and abolishes polarity at $31^{\circ}$. The ability of small changes in temperature, acting on the same genouype, to reverse or eliminate polarity, suggests that it is not a sufficiently fundamental property on which to base a functional dichotomy .

$P$ factors are chromosomally located mobile genetic elements which when present 1.1 combination with an $M$ type cytoplasm induce hybrid dysgenesis. This is manifested as male recombination, sterility, increased mutation frequency and enhanced female recombination. Preliminary studies have begun t.o measure the abllity of $P$ elements to restore more nearly normal recombination in rec- $16 /$ rec- $^{6}$ females carrying $M$ cytoplasm. Crosses were made at $17^{\circ}, 25^{\circ}$ and $28^{\circ}$. Complete sterilitv occurred at $17^{\circ}$ and fertility was greatly reduced at the higher temperatuies. Recombination was measured at $2.8 \%$ at $25^{\circ}$ which is simflar to that found in the absence of $P$ elements. At $28^{\circ}$ recombination was fucreased to $7 \%$, indicating a temperaturedependent phenomenon. 
1. Grell, R. F., Targeted recovery of temperature-sensitive and insensitive recombination-deficient alleles in Drosophila, submitted.

2. Grell, R. F., Generoso, E. E., A temporal study at the ultrastructural level of the developing pro-oocyte of Drosophila melanogaster. Chromosoma 87: 49-75, 1982.

\section{MICROBIAL MUTAGENESIS AND CELL DIVISION}

$$
\begin{array}{ll}
\text { H. I. Adler } & \text { R. Machanoff } \\
\text { W. D. Crow } & \text { A. Sozer }
\end{array}
$$

During this reporting period we have completed the development of a rapid, inexpensive microbial technique for the detection of matagens. This technique is based on the induction of filamentation in "lon" mutants of the bacterfum Escherichia coli. The newly developed test has been compared with the Ames Salmonella assay and the results have been published (2).

Most of our effort has been directed toward the development and use of new methods for growing and manipulating anaerobic bacteria. Anaerobes are of interest because some are clinically significant, others arc involved in the degradation of environmental contaminants, and still others can be useful in the production of potential fuels such as methane, ethanol, acetone and butanol from renewable resources. Anaerobes should also be useful in understanding the mechani $3 m$ by which oxygen causes inactivation and rutation. We hope that our novel methods will eventually allow us to apply the modern techniques of genetic recombination to anaerobic bacteria.

The new methods for cultivating anaerobic bacteria are based on the use of a sterile membrane fraction from Escherichia coll. The fraction efficiently reduces oxygen to water over a broad range of temperature and $\mathrm{pH}$ in both liquid and solid media. Twenty anaerobes representing ten genera have been grown in liquid media containing the membrane fraction. If bacteria and the fraction are incorporated into pour plates overlayed wirn a thin layer of agar, colonies develop without the use of anaerobic containers. Bacteria and the fraction may also be spread on agar surfaces and incubated in anaerobic containers. Both techniques have high plating eff:-ctencies. Por many kinds of experiments, bacteria must be diluted ir.io a nongrowth environment and held for considerable periods of time. We can now accomplish this for strict anaerobes without the use of anaeroblc containers. Bacterla are diluted into a solution contalning bovine serum albumin, sodium lactate and the membrane fraction in distilled water. Under these conditions, the organisms so far tested remain viable for at least 1 hour.

Before doing more sophisticated genetic mantpulation, it is necessaiy to establish some basic parameters of the organism to be manipulated. Using our newly develuped techniques, we have obtalned growth curves, 
ultraviolet and X-ray inactivation curves, and estimates of spontaneous witation frequencies for two anaerobes of interest, Clostridiun butyricue and clostridiue acetobutylicue. Both organises grow rapidly in liquid cultures supplemented with the menbrane fraction. Generation times are approxinately 36 inutes. The ultraviolet and X-ray inactivation curves are sinilar to those previously obtained for Bacillus subtilis and spontaneous mutation frequencies for drug-resistant arkers seen to be sinilar to those obtained in organisas such as Escherichia coli (1).

We are now also able to produce quantitative data for the inactivation of $\mathrm{Cl}$. acetobutylicun exposed to air. The experiments nave been performed under a variety of conditions and the inactivation curves obtained appear to be exponential without a significant inftial threshold. These results suggest that oxygen way be reacting with a cellular component that is present in only one or a small nuber of coples per cell. We have also observed that Cl. acetobutylicum cells when added to nutrient media efficiently remove dissolved oxygen. This removal of oxygen does not take place if the cells are suspended in distilled water. The removal of oxygen from nutrient broth does not seem to be an effective protective mechanism for $\mathrm{Cl}$. acetobutylicum because it is accompanief by significant 1088 of viability as judged by cloning efficlency.

A search for oxygen tolerant mutants of $C_{i}$. acetobutyllicum has been undertaken. Such organisms, if they can be found, would be useful in studies of the mechanism of oxygen toxicity and an evaluation of the role played by oxygen in determining the "spontaneous mutation rate". In order to establish selective conditions for an oxygen tolerant wutant, we have developed a system in which nutrient agar plates are spread (approximately $10^{7}$ organisms/plate) and incubated in chambers containing various amounts of oxygen added to a nitrogen- $\mathrm{CO}_{2}$ mixture. We have established that, under these conditions, our strain of $\mathrm{Cl}$. acetobutyllcum is inactivated by oxygen concentration of approximately 1.5\%. To date, no oxygen tolerant mutant has been obtained. Such mutants may occur only rarely but, because they would be extremely useful and we have now developed efficient techniques for their detection, additional experiments will be performed.

In contrast to other techniques, the membrane fraction provides a rapid and efficient means of maintaining oxygen free conditions without producing a toxic environment. In practice, many anaerobes grow more rapidly and to higher titer in med.s containing the meribrane fraction than in media made anaerobic using nonspecific reducing agents such as sodium thioglycollate or cysteine. These observations suggest that it may be possible to use membrane based techniques to 18olate unusual anaerobes from natural environments. We are testing this idea by using our techniques to isolate butanol and acetone producting anaerobes in soll samples from a variety of locations. We have obtained at least 12 such organisms. These isolates are being examined for the presence of plasmids that may be useful in gene transfer experiments.

One of them produces slightly higher concentrations of hutanol and acetone than our best laboratory strain of Cl. acetobur.ylicum. 
1. Adler, H. I., Crow, H. D., Hadden, C. T., Hall, J., Machanoff, R., New techniques for growing anaerobic bacteria. Blotechnol. Bioengineer., in press.

2. Nagel, R., Adler, H. I., Rao, T. K., Induction of filanentation by utagens and carcinogens in a lon $^{-}$utant of Escherichia coli. Mutat. Res. 105: 309-312, 1982.

\section{GENETICS OR REPAIR OP RADIATION DAMAGE TO DNA IN BACTERIA}

$$
\text { D. B11len }{ }^{3} \text { C. T. Hadden }{ }^{3}
$$

In our studies we have atteupted to deteraine how environuental agents, and especially radiation, interact with DMA and how the cells respond to the damage resulting from those interactions. We have been concerned primarily with three questions: what is the spectrum of danage generated in DNA, what kinds of damage can be repaired, and what are the mechanisms of repair? We have studied the effects of radioprotective agerits and certain sensitizing conditions on breakage of DWA in bacterial cells by ionizing radiation, and mechanisms of enzymatic excision of pyrimidine dimers and other DNA adducts.

(a) The production of strand breaks by $X$ rays in cellular DNA can result from direct action of the radiation on DNA or from indirect action. Indirect action may depend on $\mathrm{OH}$ radicals, hydrogen atoms, or solvated electrons formed by the radiolysis of intracellular water. From studies on the rates of reaction of chemlcal scavengers for the $\mathrm{OH}$ radical and their protective activities, it has been concluded that the $\mathrm{OH}$ radical is the primary cause of Indirect DNA strand breakage in cells.

Recently it has been proposed that certain protective organic compounds may function in a more complex way than by simple OH radical removal. Ewing (Radiat. Res. 68: 459-468, 1976; Int. J. Rad. Biol. 41: 203-208, 1982), using lethality as an end-point, has found that under certain conditions of irradiation the re is a correlation between radiation protection and the formation of a secondary $\alpha$-hydroxyl radical. For example, he has shown that $t$-butanol and $t$-amyl alcohol, both excellent $\mathrm{OH}$ radical scavengers that are not converted to $\alpha$-hydroxyl radicals, also do not protect Escherichia coli $B / r$ cells if they are $X-1 \mathrm{r}$ :-idiated in al $r$ or $100 \% \mathrm{~N}_{2}$ but will protect if they are irradiated in $1 \% \mathrm{O}_{2}$.

The purpose of this study was to determine whether chemical protection against single-strand breaks observed in toluene-treated E. coll (AB3063) subjected to $X$ irradiation in ai $r$ was due to the removal of of radicals, or resulted from the production of secondary radicals as proposed by Ewing. In toluene-treated cells DNA strand-break production can be measured without the complication of strand ligation during or immediately following $x$-ray exposure since such cells are deficient in DNA ligase activity. 
The seven chenicals use $J$ in this study and their rate consiants $\left[\mathrm{k}\left(\mathrm{K}^{-1} \mathrm{~s}^{-1}\right)\right]$ with ot radical were: sodiun fornace, $\left(2.5 \times 10^{9}\right)$, glycerol $\left(1.9 \times 10^{9}\right)$, cysteanine $\left(1.5 \times 10^{10}\right)$, n-butanol $\left(4.0 \times 10^{9}\right)$, t-butanol $\left(5.2 \times 10^{8}\right)$, t-anyl alcohol $\left(1.8 \times 10^{9}\right)$, and potassiun nitrite $\left(\overline{5} \times 10^{9}\right)$. According to Ewing, glycerol and formate are converted to a-hydroxy radicals by 0 th radicals but $t$-butanol and $t$-angl alcohol are not.

The data obtainad show that the production of DNA strand breaks by $20 \mathrm{krad}$ of $X$ rays can be arkedly reduced by all seven chemicals in a concentration-dependent maner shen thay are present during $X$ ray exposure.

As a convenient but arbitrary way of visualizing the relative effectiveness of the conpounds in reducing DNA breaks relative to their OH radical scavenging capacity, the reciprocal of concentration of each chenical producing a $50 z$ reduction in strand breaks was plotted against the rate constant for reaction with oH radicals. Protection by the agents against $X-r a y-i n d u c e d$ DNA strand breaks was directly related to their OH radical scavenging capacity with the exception of cysteanine. Cysteamine seens to be wre effective than would be predicted fron its OH sadical scavenging ability and is likely to protect by several mechanisas including oxygen removal, hydrogen donation, and $\mathrm{OH}$ radical removal.

It is difficult to envision that the protection is brought about by the secondary reducing radicals as proposed by Euing since the formation of $\alpha$-hydroxy radicals is not necessary for protection against DNA strand rupture in our system. If their tormation were necessary t-butanol and t-amyl alcohol should have been unable to protect the cells against DNA breaks.

Similarly, pirified DNA from Bacillus subtills was irradiated in the presence of various concentrations of protective agents and the extent of loss of biological activity was measured by transformation. In this in vitro system there are no cellular materials to interact with the DNA, radioprotective agents, or water radiolysis products. The results indicated that much lower concentrations of radioprotective agents were required to reduce the DNA damage than in the toluene-treated E. coli cells. The maximal level of prol.ection conferred by n-butanol was much greater than that of $\mathrm{KI}$, but this concentration required to achieve $50 \%$ protection was again related to the rate constant for reaction with $\mathrm{OH}$ radical.

In addition, Euing's hypothesis predicts that the protective hydroxy $\alpha$-radicals are produced through hydrogen extrac $t$ ion by $\mathrm{OH}$ radicals, and thus that radical scavengers should reduce the formation of protective $\alpha$-hydroxy radicals. In a competition experiment, $\mathrm{KI}$ did not change the protective effect of elther i-butanol, which can make $\alpha$-hydroxy radical, or t-butanol, which cannot.

We have no ready explanation for these differences between laboratorles with E. coll $X$ irradiated in air. Ewing used colony-forming ability of $E$. coll as an endpoint, and we have studied DNA breaks in tc,luenetreated E. col1. The measurement of DNA strand breaks under alkaline 
conditions re:lects $X$-ray Induced frank strand breaks and breaks resulting fron apurinic site production. The blological consequences of these lesions is not fully understood.

(b) Investigations on the manises of repair of DNA damage have included studies of the adaptive response by B. subtilis to alkylating agents. In collaboration with S. Mitra and R. S. Foote, we previously dewonstrated that $B$. subtilis cells contain a high level of $0^{6}$-methylguanine-DNA methyltransferase, and that this level is increased by exposing the cells to low concentrations of $N$-nethyl-N'-nitro-N-nitrosoguanidine (HNNG). This adaptive response reduces both kīiling and wutageresis by a challenge with $z$ high concentration of INNG. He have now shown that the adaptive response is induced by some alkylating agents, but not by others. wNG pretreatment induces protection against the lethal ef fects of methyland ethylnitrosourea (HNU and ENU) and ethyl-nitrosoguanidine (ENNG) but not methanesulfonates (MMS and MiS); it actually increases mutagenesis by MNU. Pretreatments with INU and ENU are adaptive to killing and mutagenesis by MNNG but ENMG is adaptive only to killing. MMS and EMS are not protective against INNG; ENNG Increases wagenesis by MNG. In general, the methanesulfonates react predominantly with nitrogen in DNA, whereas the nitroso compounds react ainly with oxygen. It appears that the nitrogen adducts, although lethal, are not adaptive.

(c) In a collaborative effort with $H$. I. Adler we have begun an investigation of DNA repair and mutagenesis in anaerobes. By using an E. coli cytoplasmic membrane preparation to remove oxygen $f=0 m$ liquid and solid media, we can carry out routine treatment of anaerobic bacteria without the need for anaerobic chambers or toxic reducing agents. We have shown that the dose res: ise of clostridium butyricum to killing by ultraviolet radiation is essentially the same as that of $B$. subtilis. These two organisms are also similar in their response to Ionizing radiation in the presence of afr. Comparison of dose response of C1. butyricum in aerobic and anaerobic conditions shows an oxygen enilancement ratio of about 3 , as is typical for aerobic and facultative bacteria. These experiments show that studies of DNA damage, repair, and wutagenesis of anaerobes should be fasible. Information gained from these studies shot ld facilitate the improvement of industrially useful strains of anaerobes.

1. Billen, Daniel, The effects of radioprotectors on DNA polymerase I-directed repair synthesis and DNA strand breaks in toluene-treated and x-irradiated Escherichia coll. Radiat. Res. 95: 158-164, 1983.

2. Billen, Daniel, The role of hydroxyl radical scavengers in preventing DNA strand breaks induced by $x$-irradiation of toluene-treated Es,cherichla coll. Radiat. Res., in press.

3. Hadden, Charles T., Foote, F. S., Mitra, S., Adaptive response of Bacillus $\frac{\text { subt1l18 }}{153}$ to J. Bacteriol. 153: 756-762, 1983. 


\title{
ANALYSIS OF TERATOGENS AND POTENTIAL TERATOGENS \\ USING FETAX (FROG EMYRYO TERATOGENESIS ASSAY: XENOPUS)
}

\author{
Janes N. Dunont Rhonda G. Epler
}

The development of abnorwal embryos and fetuses has been of concern since the time of Aristotle. In wre recent times, especially since the thalidonide episode in the 196n's, there has been a resurgence of interest In the factors that influence both normal and abnormal embryonic and fetal development. Even wore recently, with the advent of the revolution in the synthesis, manufacture, and application of new pharmaceuticals and chemicals and of new forms of energy production which may produce streans of complex rixtures of many compounds, potential birth effects resulting from the use of and/or exposure to these compounds or mxtures has becone a major health and environmental concern. This concern has generated an intense interest in the developwent of biological assay sysiems with which potential embryonic and fetal danage might be detected in a rapid and ccst effective manner. The FETAX systen was developed in response to this need. The assay is rapid and cost effective and uses the developing embryos of the amphibian, Xenopus laevis. Enbryos are exposed for 96 hours beginning at the mid to late blastula stage of development. The end-points of the assay are easily scored ard provide information on embryotoxicity and teratogenicity, and, in addition, data on the relative toxic or teratogenic potential. These relative potencies are used to suggest priorilles for further testing in more advanced and expensive systems.

In addition to providing guldance for more costly testing, the FETAX system can be useful for studying effects of teratogens on specific organ systems as well as providing a model to examine teratogenic mechanisms. Not all teratogenic effects are produced by genetic damage. Some teratogens affect cytoplasmic or cell membrane components and thus interfere witr. normal celi sorting and organization in the embryo. other teratogens act by killing cell populations and in this way prevent normal development of organs and organ systems. Since FETAX is a whole embryo system, it tis useful for studying these effects and can provide fundamental Information on the mechanisms of aberrant developmental phenomena. Similarities between mamalian (or human) and amphibian responses make detalled study of the blological effects of teratogens in embryos much easier to implement. Thus, FETAX provides a rapid and cost effective means of evaluating the teratogenic potency of compounds (or complex mixtures), and a system with which fundamental information on underlying mechanisms can be obtalned.

The attributes of FETAX which make it appealing as a model include the facts that it 18 a whole embryo system, that large numbers of embryos are avallable, that teratogenic and embryotoxic effects can be differentiated, and that quantitative dose-response relat:onships are displayed. In addition the assay is adaptable to a variety of testing protocols and it can be used to study developmental abnormalities in both t.le axial and appendicular skeietons.

FETAX has been validated with 40 known mammalian teratogens and nonteratogens. Those used for validation during this year include pesticldes (Carbaryl, Disulfram, Captan, Lindane and Crlqeofluvin), an 
Iahibitor of oxidative phosphorylation (2,4-dinitropheno1), a compound used as a solubility vehicle (propylene glycol), a caticn chelator (EDTA), and two phareaceuticals, an antihistarine-antinausiant (meclizine) and antinitotic and antineoplastic agents (Velban, vinblastine sulfate, cyclophosphanide, and methotrexate). One of the pesticides, Captan, gave a false negative result but the response of FETAX for the remaining conpounds gave results consistent with those obtained in mamals. The false negative rate for all conpounds rested 1 s $\sim 10 z$ and $t$.re false positive rate is $\sim 5 \%$. These rates conpare very favorably with those obtained by other teratogen in vitro assays and with the rellability of the now classical Ames test for Eutagens. Conclusions about teratogentcity are based on the TER:TOGENIC INDEX (TI), a nuber that is generated fror the ratto of the $L_{50}$ and the $\mathrm{EC}_{50}$ (the concentration of teratogen that produces $50 \%$ abnormals among the survivors at 96 hours). TI's of 1.0 or less indicate that the material is enbryotoxic while TI's of 1.0 or wore indicate that the test aterial is teratogenic. The larger the value of the $T I$ the greater the teratogenic risk. It 18 on the basis of the TI that priorities for longer term mamalian tests are recomended.

Hork is ongoing to exanine specific cellular and tissue danage as a result of teratogen exposure. More detailed analyses of abnormal development include quantitative analyses of tissue and organ abnorwalities using conputer-assisted morphonetric methods. We have, for example, found that wethotrexate (a folic acid antagonist and abortifacient as well as an antineoplastic agent) causes severe hydrocephalia in developing embryos, a syndrome common to human fetuses and neonates whose mothers have used the drug. Our morphometric analyses have shown a 20-30z reduction in the area of the brain occupled by cell mass. While the cross-sectional area of the brain 18 relatively unaffected, the area of the ventrical is gre.". increased. The increase is dose dependent but at a concentration of $150 \mathrm{mg} / \mathrm{L}$ ventricular area is increased by as much as 38 times over that of the control. These resulics demonstrate that similar responses occur in both amphibian and mamalian embryos. Although the mechanisms involved in the induction of hydrocephaly are not specifically known, one suspecrs that the chorold plexus that secretes cerebrospinal fluid might be defective.

Lathyrogens, compounds that Induce skeletal and connective tissue defects in mamals, Induce siwlar defects in amphibian embryos. Electron microscopic studies of the notochords of lathyrogen-treated embryos reveal that the collagenous sheath that surrounds the notochord is highly disarrayed and attenuated. As a result the notochord ruptures through its sheath and the long axis of the embryo becomes distorted. Cross-sectiona: area of the notochord my increase by as wach as 5 times that of controls. Later premetamorphic embryos (1.e., those with well developed exbryonic 11mbs) exposed to lathyrogens exhibit, after metamorphosis, abnormalities in their appendicular and axial skeletons. Histologic examination of skeletal joints reveals abnormal jolnt capsule development. As a result the embryos are unable to swim normally.

It 18 well known that some compounds require activation or metabolism to become teratogenic. Cyclophosphamide 18 such a compound. Although it ylelds positive results in PETAX, it also causes abnormal development of limbs and digits in older embryos (as in the mammal, shortened limbs and 
loss of digits). These effects are enhanced by prior treatment of the embryos with phenobarbitol, a classic inducer of bioactivating enzymes. In addition to providing $a$ codel with which to study linb and digit abnormalities, this observation also denonstrates (1) that later stage embryos possess activating enzyne systems and (2) that these systems can be enhanced by classic inducers. The fact that linb developwent can be affected broadens the application of FETAX to include later stage embryos that are actively undergoing limb development.

Validation of the assay with a broader base of teratogens and nonteratogens will allow rapid and cost-effective establishment of priorities for other chenicals for further testing as well as provide insights into the mechanisus by which aterials affect enbryonic and fetal development. The assay has been applied to a host of potential environsentally hazardous materials, my of which were derived from ewerying energy technologies. These investigations contribute to and support a prevalling Interest of the Division and Laboratory with regard to potential health and environmental hazards that are assoctated with the development of alternate energy technologies.

1. Dumont, J. N., An overview of bioassa;s for utagens, carcinogens and teratogens, in Proceedings of UCC-ND and Goodyeár Atomic Envi $\mathrm{L}_{2}$ snmental Protection Seminar, ORNL CONF. 820418, PP. 489-510, 1982.

2. Dumont, J. N., Brumnett, A. R., Egg envelopes: Vertebrates, in Browder, L. (ed.): Developmental Blology, rol. 1, Oogenesis, In press.

3. Dumont, J. N., Schultz, T. W., Buchanan, M. V,, Kao, G. L., Frog embryo teratogenesis assay: Xenopus (FETAX) - A shurt-term assay applicable to complex environmental mixtures, in Waters, M. D., Sandhu, S. S., Letwas, J., Claxton, L., Nesnow, S. S. (eds.): Short-tern Bioassays in the Analysis of Complex Environmental Mixtures III, Plenua Publ. Corp., 1983, Pp. 393-405.

4. Newman, S. M., Jr., Dugan, T. W., Dimont, J. N., A rapid and simple method for the visualization of amphibian skeletons in teratogenic studies. Trans. Am. Microsc. Soc. 102: 300-305, 1983.

5. Newman, S. M., Jr., Dumont, J. N., Thlosemicarbazide Induced osteolathyrisi In metamorphosing Xenopus 1aevis. J. Expt1. 2001. 225: $411-421,1983$.

6. Schultz, T. W., Dumont, J. N., Teratogenicity and embryotoxic:" of monosodium methanearsonate herbicide. Trans. Am. Microsc. Soc., In pres8.

7. Schultz, T. H., Duwont, J. N., Buchanan, M. V., Toxic and teratogenic effects of chemical class fractions of a coal-gasification electrostatic precipitator tar. Toxicology, in press.

8. Schultz, T. H., Dumont, J. N., Rao, T. K., Guerin, M. R., Ma, C. Y., Epler, J. L., Evaluation of hydrotreatment as a means of reducing biolcgical activity of synfuel related material. Environ. Res. 29: 389-398, 1982.

9. Schultz, T. H., K!er, L. B., Dumont, J. N., Structure activity relationsh1p8: ineir function in biological prediction, in 5th Life Sclences Symp., Synthet1c Possil Puel Technologies: Results of llealth and Environmental Studies, 1983. DOE/ORNL CONP. 821048, In pres8. 


\title{
Mammalian Genetics and Reproduction Section
}

\author{
SECTION OVERVIEW - LIANE B. RUSSELL
}

The unffying theme of the Section's research is the mamalian germ1ine. More specifically, the work deals with both the direct and transmissible effects of environmental agents on amalian germ cells, and with basic information on the structures and processes in which these effects occur.

Five subthemes nay be identified. (1) The frequency of induced heritable damage. It includes the detection of inherited lesions representative of various endpoints, and the study of their relative frequencies depending on biological and physical variables. (2) Basic genetics and cytogenetics, including the genetic and fine-structure analysis of induced and spontaneous mutational changes, and studies of chromosome behavior in the germline. (3) Developwental genetics and the study of phenotypes. We are concerned not only with the frequency of wutations but also with their effects, particularly such dominant effects as inherited sterflity and morphological anomalles. (4) Reproductive biology. The study of normal and abnormal gametogenesis, germ-cell transport, fertilization, early embryonic development, and the effects of various agents on these processes is inextricably tied to mammalian genetics. (5) The interaction of chemical agents with germ-cell DNA. This includes detection of primary DNA damage in gonads by means of both unscheduled DNA synthesis (UDS) and indices of fragmentation, and the measurement of molecular doses in germ cells.

Intimate, and often reciprocal, relationships exist among several of these major themes. Thus, mutagenesis experiments produce altered genes and chromosomes, and thereby supply tools for basic studies; in turn, detalled information on the structure and behavior of specific genomic regions helps in understanding what type of mutagenic agent induces what type of genetic lesion. Certain gross phenotypes can also be related to certain basic genetic lesions, e.g., Inherited male sterility to specific types of chromosomal conditions. A detalled understanding of normal germline development and studies on direct germ-cell effects (e.g., cell killing) are essential in illuminating secondary factors in mutagenesis (such as cell selection or repair) that can reduce transmission of mutations, and In making the all-important correlations between exposed germ-cell stage and quantity and/or quality of genetic lesions transmitted to of fspring. Finally, cherical dosimetry studies in the gonad are a prerequisite to the interpretation of mutagenesis daca.

As in the past, method development and validation have this year been carried out in a diversity of areas. Some examples follow. 
- Non-breeding-test (NBT) Indices for wore rapid estimation of doninant skeletal effects have been show. to be scorable in a genetically randon population; NBT experiments can, as a result, be piggy-backed on specific-locus studies.

- The use of long-tern inhalation exposures in mugenesis studies was perfected in an investigation of ethylene oxide (Et0) effects. This peratted coordinated experiments on Eto induction of a nunber of different genetic endpoints, as well as molecular dosinetry studies with this inhaled agent.

- Alkaline-elution procedures sere develo- $=d$ to measure DNA strand breaks In spermatozoa. In, so far, linited $38 \mathrm{ts}$ the magnitude of elution values parallels the frequency of doninant let hals. If further correlations can be demonstiated, the method may become useful in the monitoring of buman sperm for DNA breakage.

- Modifications in enbryo freezing and transfer were worked out which will permit improvements in the cryopreservation of our genetic stocks. Embryo transfer also pernitted a study on the causes of spontaneous early embryonic death.

- A computer analysis was devised that permits the reliable detection of even small excesses in early mortality of first-generation offspring of mutagenized animals. Worked out for radiation studies, this type of analysis will be applicable to experiments with chemicals and will provide yet another measure of Induced dominant damage.

- High-resolution chromosome banding has been successfully worked out for mouse chromosomes and will permit a greatly superior cytological localization of certain genetic lesions.

- A high-dose fractionation regimen fGr ENU was worked out that further increases the effectiveness of this supermutagen. Our discoveries of efficient methods for producing new mutations are receiving worldwide application in laboratories desiring to produce mouse models for human genetic disorders.

- A critical examination of methodologies that have been used to detect Induction of chromosomal nondisfunction in meiosis led to the identification of the most promising approaches as well as of melotic stages at which mutagen should be applied to maximize the chance of inducing nondis function.

Although testing of chemicals is not a major objective of this Section, a nusber of substances were investigated this year. In addition to some of the standard alkylating agents, which, along with radiation, were used as tools in the investigation of blological processes or for method development, the agents studied for genetic and/or reproductive 
effects were ethylene oxide, dibromochloropropane (DBCP), hexamethylphosphoranide (HMPA), nitrosoethylcarbanate, ethanol, mercury (as methylmercuric hydroxide), various seed olls and uineral oil, and 239 plutonium. The related compounds, ethylnitrosourea (ENU) and methylnitrosourea (MNU), were used for in-depth studies to explore the biological variables that affect wtagenicity in mamalian germ cells.

This last group of experiments, as well as a number of others, provided some important findings on the properties of the biclogical system and about the nature of its interaction with environmental agents. Some examples follow.

- Gera-cell-stage-related sensitivity was found to differ greatly for different chemicals, even in the case of chenicals as closely related as ENU and MNU. While MNU has little mutagenic effect in stem cell spermatogonia, in contrast to the suirermutagenicity of ENU in these cells, it is extremely mutagenic (and probably more so than ENU) 1:2 a very short post-stem cell stage.

- The array of genetic changes that causes sterility in offspring of Irradiated les is very different depending on whether spermatogonia or postgonial stages are irradiated.

- The frequency of spontaneous early embryonic death is controlled largely by the genotype of the embryo, which determines development rates, and little, if at all, by the genotype of the uterus within which the embryo grows up. The high frequencies of deciduomata that characterize certain strains thus do not result from newly-occurring dominant-lethal mutations.

- Spermatogonial stemcells of the mouse testis do not exhibit a clear circadian rhythm in mitotic activity, nor do cell-cycle properties of these spermatogonia change with age of the males from 3 weeks on. Stemcell numbers, however, decline with age.

- Chemlcals that react by an $S_{N} l$-type mechanism interact much less with protamine than do chemicals that react by an $S_{N} 2$ mechanism.

- The relative frequencies of various alkylation products formed after ENU infection change with exposure level. A decrease in the $0^{6}-\mathrm{EG} / \mathrm{N}^{7}-\mathrm{EG}$ ratio as exposure is lowered parallels a significant drop below linearity in mutation rate. The results are consistent with evidence from other systems that $0^{6}-E G$ is an important mutageric lesion, and one that can be repalred.

- An attempt to saturate the $0^{6}-G$ alkyl transferase in a spot-test experiment was successful with regard to teratogenic effects but unsuccessful with respect to mutations in pigment cells.

- Comparisons of dominant-lethal and heritable-translocation induction by various alkylat1.28 agents suggest that these two typ.ss of lestons may 
arise along different pathways. Translocations are associated with the formation of unstable $N^{7}$ alkylguanine, which produces interwediate lesions that are converted into chromosome exchanges following sperm entry into the egg. Doninaxt-lethals ay result from stable alkylations at oxygen positions, which, during pronuclear chromosone replication, lead to chromatid-type aberrations.

From the beginning, a major thrust of the mammalian genetics progran has been the assessment of geneti a risk. It should be obvious that several of the studies here sumarized in other contexts have at least some bearing on genetic risk assessment. Several additional highlights may be listed.

- The most extensive and rellable study on the frequency of heritable translocations induced by radiation in spermatogonia was completed this year. Spermatogonial stemcells are of prime importance in risk estimation.

- An analysis made possible by a new measure of pre-adult deaths from all causes, including aneuploidies, strengthens the conclusion that, for radiation, there is less genetic risk from chromosomal aberrations than from gene mutations.

- An attempt was made to evaluate the degree of rellability with which various types of mutagenesis data from tests other than mammalian germline tests can identify possible genetic hazard, and can be used to establish priorities for choosing chemicals on which to proceed to risk assessment.

- Since heritable translocations pose a much greater risk to human populations than do dominant lethals, the finding that these two types of chromosomal endpoints may result from different basic types of DNA lesions has considerable importance in evaluating risk from specific chemicals.

- Among chemicals studied this year are several to which human beings are exposed, e.g., corn ofl and other seed ofls, ethanol, ethylene oxide, and organic mercury.

Our work In basic genetics and cytogenetics continues to make good use of chromosomal aberrations and point mutations that are generated in the course of mutagenesis studies.

- The continuing electron-microscope analysis of synaptonemal complexes of $X$-autosome translocations has provided evidence against homology in $X-Y$ synapsis.

- Cytological studies on fertility-impalred of spring in heritabletranslocation experiments have led us to the conclusion that all Yautosome translocations may be sterile. 
- Autosomal reciprocal translocations that do not sterilize were used in a study on the relation between length of exchanged segments and frequency of aneuploid progeny.

- Detailed analysis of mutations recovered in specific-locus experiments has been extended to a new locus, $\underline{p}$, at which a major deficiency has been identified.

- There is evidence that ENU-induced mations are probably swaller genetic lesions than are radiation-induced mutations.

Since we lost our teratologist, Ron Filler, in September 1982 during the reduction in force, teratology efforts were put on hold this year. However, work in other areas of reproductive biology continued at full force. In addition to conducting studies (some of which are summarized above) on germ-cell histology and on the ir.teraction of chemicals with germ-cell DNA, we are working at several of the interfaces between genetics (or matagenesis) and reproductive biology.

- Effects of chemicals or radiations on lifetime fertility of exposed animals are analyzed as an ancillary result of specific-locus studies in males. Such effects are studied in the total-reproductive-capacity test on females, along with clastogenic effects. Fertility impairments in offspiting (as opposed to those in exposed animals) are among the dominant genetic effects under study.

- Fertilizalion and early cleavage are stages that enter into studies of various induced and spontaneous events. Among these are the induction of nondisjunction, the occurr, ef chromosome exchanges or losses resulting from lesions induced earlier (in germcells), the repair of such lesions in the fertilized egg, the possible induction of abnormal fertilization (e.g., sperm entry in the polar body), and the genetic control of mortality of early embryos.

- Embryo-manipulation techniques acquired and perfected as part of the stock-freezing program are being utilized for other studies.

IN-DEPTH STUDY OF CHEMICAL MUTAGENESIS IN MOUSE GERM CELLS USING N-ETHYL-N-NITROSOUREA (ENU) AS A MODEL MUTAGEN
W. L. Russel1 7
P. R. Hunsicker
D. A. Carpenter
E. L. Phipps
C. S. Montgomery

J. W. Bangham

G. M. Guinn

M. H. Steele

H. M. Thompson, Jr.

Our discovery in 1979 that EMU is by far the most effertive of all mutagens 80 far tested in the mouse made it feasible, for the first time, 
to perforn extensive studies if the chemical and biological factors, such as dose, dose fractionation, sex, cell stage, etc., that can af fect gene mutation rate in mouse germ cells. We had deternined the effect of these factors in radiation mutagenesis, but very little research of this kind had been possible in chorical mutagenesis, mainly because of the relative Ineffectiveneis of chemical mutagens on mammalian germ cells, and the large numbers of animals required to measure low mutalion rates. Prior to the discovery of the effect of ENU, the most effective chenical mutagen known in the mouse was only one-third as effective as acute $X$ rays. In contrast, a single use of ENU is 8 times as effective as the most effective single dose of $X$ rays. As a result, rapic progress is being made in exploring how ENU-Induced mutagenesis is affected by the factors mentioned above.

Dose-response curve for ENU-induced spectfic-locvs mutations in spermatogonja. Last year we reported that in the lower portion of the dose-response curve, below a dose of $100 \mathrm{mg} / \mathrm{kg}$, the data fell statistisalıy significantly below a maximum-likelihood fit to a straight line. Results at the $50 \mathrm{mg} / \mathrm{kg}$ dose point have been increased to explore the magnitude of this reduction. The total mutation frequency at this dose is now 26 mutations in 35,956 offonring. This continues to be statistically iughly significantly below a linear response, and the induced mutation frequency Is only $45 \%$ of that expected on a linear interpolation between the frequencies at 0 and $100 \mathrm{mg} / \mathrm{kg}$.

Effect of sex and cell stage. For the estimation of genetic risk, it is important =o know the relative mutational sensitivities of the various germ-cell stages. Last year we reported that ENU-Induced mutation frequency in postspermatogonial stages is very low compared with that in spermaiogonial stemcells. However, we pointed out that even with the lowest dose used, $100 \mathrm{mg} / \mathrm{kg}$, no of fspring were recovered from matings made during the sixth and seventh weeks post-injection, owing to the lethal effect of this dose of ENU on differentiating spermatogonia and early spermatocytes. It was important to test the mutational sensitivity of these stages to ENU, because we had discovered that they are extremely sensitive to mutation induction by methylnitrosourea (MNU). Accordingly, we have now performed $81 x$ replications of an experiment with a $50 \mathrm{mg} / \mathrm{kg}$ dose of ENU which does allow some survival of cells in the stages of interest. In watings made in the period between 32 and 42 days after injection (the period that gives the high mutation rate with $\mathrm{MNU}$ ), we have obtained 4 specific-locus mutations in 5,576 of fopring. Th1s is a marikedly different mutation rate from 1 mutation in 20,836 of fpring obtained from matings made in the period before 32 days after injection. The difference 1s statistically significant $(P=0.008)$. Thus, as with MNU, differentiatIng spermatogonia or early spermatocytes are mutationally sensitive to ENU, and the currently estimated mutation frequency with ENU Is simllar to that induced by the same dose in stemcell spermatogonia.

In a new experiment with female mice infected with $100 \mathrm{mg} / \mathrm{kg}$ of ENU, the animals were not mated unt11 two weeks after treatment, thereby increasing our sample size of oocytes exposed in an intermediate stage of the maturation process. In a total of 1,226 of fopring from matings made in 
the third t.J sixth week after injection, no mutations were obtained. Matings made after the sixth week in this experiment, and other earlier experiments continued through this year, produced 7,749 offspring from cells exposed as arrested oocytes. This group also yielded no mutations, thereby continuing to show the $j$ zeffectiveness of ENU in inducing mutations in female mice, despite its powerful effect in stemcell spermatogonia.

Mutagenic effect of sequential exposure to $X$ rays and ENU. The rationale for this experiment was based on our finding that splitting an $X$-ray dose into two fractions separated by 24 hours greatly augments the mitation rate in spermatogonia, presumably because germ-cell death from the first exposure results in a synchronization of cells such that the second exposure finds them in a stage of high sensitivity. This experiment was conducted to test whether a dose of $X$ rays would have a simllar augnenting effect on a dose of ENU given 24 hours later. In three experiments using 100,300 , or $500 \mathrm{R}$ of $x$ rays, followed 24 hours later by an injection of $100 \mathrm{mg} / \mathrm{kg}$ of ENU, a total of 13 specific-locus mutations was obtained in 4,394 offspring. On the basis of past single-exposure radiation and ENU experiments, the number of mutations expected in the 4,394 offspring would be 2.6 from $X$ rays, 13 from ENU, and 0.2 spontaneous, or a total of 15.8 mutations. The observed frequency of 13 mutations is not significantly different from this and, therefore, so far shows no departure from an additive effect of the two mutagens, and no suggestion of any augmenting effect.

Relative mutation frequencies at the seven specific loci. Allelism tests are now complete for the mutations in the dose-response experiments, with the exception of the additional experiment at the $50 \mathrm{mg} / \mathrm{kg}$ dose. The distribution of mutations among the loci 18 siuilar at all doses where the numbers are large enough for usefu? comparison. These results do not support the claim by Ehling (In de Serres, F. J., Sheridan, W (eds.): Utilization of Mammalian Specific Locus Studies in Hazard Evaluation and Estimation of Genetic Risk, Plenum Press, New York, 1983, pp. 169-190) that the mutation spectrum changes with dose, a conclusion he reached from the data he reported at two doses, 160 and $250 \mathrm{mg} / \mathrm{kg}$. However, by our calculation, the distributions he obtained at these two doses did not differ significantly from each other $(0.5>P>0.3)$. Picking out, after the event, as Ehling did, the two loc1 that happened to show the largest difference in such a comparison, where there are 21 combinations of two loct to choose from, can lead to false statistical impressions.

Use of large-dose fractionation to augment mutation rate in spermatogonia. Results obtained this year show that the mutation frequency can be Increased above that produced with $250 \mathrm{mg} / \mathrm{kg}$ by giving 4 fractions of $100 \mathrm{mg} / \mathrm{kg}$ spaced at weekly intervals. In our specific-locus mutation test, tr.1s dose regimen has produced 17 mutations in 1700 of fopring. Th1s is $1.6 \times$ the mutation frequency of 104 mutations in 16,693 offepring obtalned in our total published results from $250 \mathrm{mg} / \mathrm{kg}$ single-dose experiments. The length of the temporary sterile period was not increased significantly over that induced by a single dose of $250 \mathrm{mg} / \mathrm{igg}$. Shorter fractionation intervals ( 1 day, 2 days, and 4 days) were tried, but the mortality and 
fertility effects rendered these undesirable for a standard experimental procedure.

Widespread use of ENU in mamalian mutagenesis. In our 1979 publication announcing the discovery that ENU is a supermutagen in the mouse, we stated that "ENU would now seem to be the mutagen of choice for the production of new mutations in the mouse whenever gene mutations of any of various kinds might be needed." This has already happened internationally, and to such an extent that Professor Willian F. Dove of the University of Wisconsin has started a monthly "House Mutagenesis Memo" to circulate and "exchange technical information and utant production rapidly, rather than through publications" in order "to optimlze a new thrust in mouse genetics to explicitly produce NEW mutations of critical value." It is gratifying to know that ORNL has made this useful contribution to the scientific community, a contribution which, through the production of mutant mouse models of human disease, is likely to have important medical benefits.

USE OF METHYLNITROSOUREA (MNU) AS A MODEL MIJTAGEN TO EXPLORE BIOLOGICAL VARIABLES AFFECTING MUTAGENICITY IN MOUSE GERM CELLS

$$
\begin{array}{ll}
\text { W. L. Russel17 } & \text { K. F. Stelzner } \\
\text { P. R. Hunsicker } & \text { S. C. Maddux }
\end{array}
$$

In last year's report we presented doubly surprising results with MNU. In the first place, MU proved to have little mutagenic effect in stemcell spermatogonia, in contrast to the supermutagenicity of ENU in these cells. Secondly, MNU turned out to be an extremely potent mutagen in post-stemcell stages, but only in one narrow window of these stages - namely, in the of fspring of matings made between 32 and 42 days after injection, which correspond to cells that were exposed either as differentiating spermatogonia or as preleptotene spermatocytes. The dose used in the experiment reported last year was $75 \mathrm{mg} / \mathrm{kg}$. We have now repeated the study with a dose of $44 \mathrm{mg} / \mathrm{kg}$ of MNU. The experiment was designed partly to check the response by augmenting the data, partly to measure dose response, and partly to compare the resulte with those from ENU experiments summarized in the preceding report ( $44 \mathrm{mg} / \mathrm{kg}$ of MNU befing equimolar with $50 \mathrm{mg} / \mathrm{kg}$ of ENU).

In the matings made in the $32-42$ day period sfter injection, 21 specific-locus mutations were obtained in 10,027 of $\mathrm{spring}$. In all other matings involving post-stemcell stages, (matings made on days $1-31$ and 43-49 after injection) only 3 mutations were obtained in 25,656 of fspring. The difference is highly significant ( $\left.P<1 \times 10^{-8}\right)$, confirming the results reported last year. The mutation frequency is slightly, but not significantly, below what would be expected on a linear interpolation between the frequencies at 0 and $75 \mathrm{mg} / \mathrm{kg}$. MNU appears to be more effective than ENU in these mutationally sensitive germ-cell stages, but even at $50 \mathrm{mg} / \mathrm{kg}$ of 
ENU there is ciearly wre killing of these cells than there is with $44 \mathrm{mg} / \mathrm{kg}$ of MNU, and this may obscure the true witation rate witii ENU.

These surprising results on the supersensitivity of certain germ-cell stages should provide useful clues on the wechanisus of utagenesis in mamalian gern ceils.

1. Russe11, W. L. Relation of mouse specific-locus tests to other nutagenicity tests and to risk estimation, in de Serres, P. J. (ed.): Utilization of Specific Locus Studies in Hazard Evaluation and Estimation of Genetic Risk, New York, Plenun Press, 1983, Pp - 109-123.

IJSE OF MNU-ENL DOUBLE EXPOSURE IN THE SPOT TEST TO EXPLORC THE IN VIVO ACTION OF AN $0^{6}$ ALKYL TRANSFERASE

\section{Liane B. Russell C. S. Montgomery}

Alkylations at the $0^{6}$ position of guanine are considered to be more highly mitagenic than alkylations at certain other sites in DNA, possibly explaining, in part, the high mutagenicity of ENU (ethylnitrosourea) found by us in mouse spermatogonfa. Experiments in the Biology Divisions of ORNL (Mitra) and Brookhaven (Setlow) have identified and studied a transferase that de-alkylates the $0^{6}$ position in bacterial and mammalian in vitro systems, leading to repair of the genetic lesions. There is some evidence that this enzyme may be more effective in removing meithyl than ethyl groups. The enzyme is thought to undergo irreversible ("suicidal") changes or accepting the a!kyl groups in a stolchiometrical fashion.

To explore the action of this transferase in mamalian cells in vivo, we carried out a mouse spot test in which exposure to MNU (methyi nitrosourea) was followed by ENU-exposure. If, in fact, most of the avallable transferase 18 tied up (and thus inactivated) by removing the $0^{6} \mathrm{G}$ methyl groups resulting from the first exposure, little or no active enzyme should remain to "repair" the subsequent ENU-caised ethylations, and the mutation rate should be greater than additive.

Pregnant females at $10-1 / 4$ days of gestation were injected with $3 \mathrm{mg} /$ $\mathrm{kg}$ MNU, followed an hour later by $25 \mathrm{mg} / \mathrm{kg}$ ENU. Other groups of females recelved one or the other chemical alone, or phosphate buffer only. With respect to recessive mutations (RS-type spots) and cytotoxicity of melanocytes (WMVS), the treatments appeared to be additive. However, the teratogenic effects of ENL (digital anomalies) were greatly enhanced by the pre-treatment with MU.

It may be that the transferase 18 not present in plgment precursor cells, or that 1 ts action there 18 not sulcidal. In the appendicular 
primordia, on the other hand, the transferase may act in line with predictions from other systems.

1. Russell, Liane B., The mouse spot test as a predictor of heritable genetic danage and other endpoints, in de Serres, F. J. (ed.): Chentcal Mutagens, Vol. 8, New York, Plenun Press, 1983, pp. 95-110, 1983.

2. Russell, LLane B., Relevance of the wuse spot test as a genotoxicity Indicator, in Banbury Report 13: Indicators of Genotoxic Exposure in Man and Antmals, 1982, pp. 379-391.

3. Russell, L. B., The mouse spot test: Procedures and evaluatiors of results, in Rilbey, Brian J. (ed.): Handbook of Mutagenicity Test Procedures, Elsevier-North-Holland Biomedical Press, In press.

\section{SPECIPIC LOCUS STUDIES WITH DBCP AND HMPA}

$\begin{array}{ll}\text { LIane B. Russell } & \text { C. S. Montgomery } \\ \text { P. R. Hunsicker } & \text { M. H. Steele } \\ \text { G. M. Guinn } & \text { K. F. Stelzner } \\ \text { S. C. Maddux } & \text { H. M. Thompson, Jr. }\end{array}$

Under contract with the National Toxicology Program, we are enlarging the data base for chenicals investigated 1t. the specific-locus test. Two chemicals were studied this year.

1. 1,2-dibromo-3-chloropropane (DBCP). Th1s pesticlde has shown mutagenic (or related) activity in various systems and 18 suspected of causing fertility impairments in men, but had not been tested for induction of transmissible effects, except for dominant lethals (positive, rat; negative, mouse). We have carried out a large specific-locus study, preceded by a toxicity test ( 9 exposure levels) and a fertility experiment. The major portion of the specific-locus test (SLT) was carried out with males that received five dally $1 . p$. Injections of $80 \mathrm{mg} / \mathrm{kg}$ each (total exposure, $400 \mathrm{mg} / \mathrm{kg}$ ) of DBCP in corn oll. These males showed no fertility disturbance at any interval after treatment. A histological study of germ-cell survival in the testis also showed no effect. Because these results seemed at variance with some earlier reports, a second batch of DBCP was obtained from the NTP chenlcal repository partway through the study. Like the first batch, it produced no fertility disturbances.

In the SLT, 34,451 and 5,940 of fopring were classified from $400 \mathrm{mg} / \mathrm{kg}$ exposed stemcell or poststemcell stages, respectively. About $50 \%$ of the former group came from fathers exposed to batch $A$, the remsinder from fathers exposed to batch B of DBCP. Only one rutant was found; it derived from spermatogonial stemcells exposed to batch $A$. The mininum multiple of the control rate that 18 ruled out (at the $5 \%$ probability level) by these 
results is 1.6 for spernatogonial stemcells, and 8.4 for poststencell stages. Since, in earlier studies (Lee, I. P., Suzuki, R., Mutat. Res. 68: 169-173, 1979), DBCP was shown to Induce UDS in wouse sperr-tocytes, it is unlikely that the absence of induced mutations in spernatogonial stencells found in our experiment results from a fallure of the chenical (or its netabolites) to reach the testis.

2. Hexamethylphosphorantde (IMIPA). This chenical inducec various mutational endpoints in Drosophila, but has yielded conflicting results in mamalian in vitro tests. We carried out a spesific-locus study at the MTD of $2000 \mathrm{mg} / \mathrm{kg}$ (dissolved in HBSS and adninistered by 1.p. injection). No fertility disturbances were noted at any interval after exposure. In the SLT, the spermatogonial stencell result (no mations in 20,998 of fepring classifled) was clearly negative and rules out (at the 57 prodability level) an induced rate $i .7$ times the control rate. The sample derived from exposed poststencell stages, 2901 offspring with no utations, yielded an inconclusive result, ruling out only 18.2 times the control rate. It is not known whether HMPA (which is highly reactive at point of entry) reached the testis.

THE EFPECTS OF IMHALED ETHYLENE OXIDE ON INDUCTION OF HERITABLE GENE MUTATIONS
Liaue B. Russell
J. W. Bangham
R. B. Cu: Ing
D. A. Carpenter
P. R. Hunsicker
E. L. Phipps

Because of the industrial inportance and widespread human exposure to ethylene oxide, EtC, this chemical poses a potential risk to future generatlons, In addition to any carcinogenic risk it may hold for this present generation. The induction by EtO of several types of genetic changes has been demonstrated in some non-mammalian systems and in mamailan in vitro assays and somatic tissues. In the mammalian germline, Eto can Induce DNA lesions, clastogenic effects, and direct damage in melotic and postmelotic cells. However, none of the prior studies has addressed the possible Induction of gene wutations in the germline; nor has it involved spermatogonial stemcells, the cell stage of greatest importance in assessing genet Ic risk to men.

In a large-scale Inhalation study, we exposed male $\left(101 \times \mathrm{C}^{\mathrm{H}}\right) \mathrm{F}_{1}$ mice to Et0 in "workday" perlods (6 hours/day, Mondays-Fridays), mostly at the level of $255 \mathrm{ppm}$. Total exposures were $\sim 100,000 \mathrm{ppm} \cdot \mathrm{h}$ or $\sim 150,000 \mathrm{ppm}^{\circ} \mathrm{h}$. Although males were exposed up to 22 weeks, survival was good except in one group that recelved the E1rst part of the treatment at $300 \mathrm{ppm}$. Maltes were mated to multiple-recessive T-8tock females shortly after the end of the Inhalation period, and (following an initial 2-weeks during which dominantlethal effects depressed the littersize) bred normally for the remainder of the study. 
Altogether, 71,387 offspring were classified in the experiment and 5 matation observed, including a cluster of two. In the $\sim 100,000 \mathrm{ppn} \cdot \mathrm{h}$ group, the results ruled out (at the $5 \%$ sigalficance level) an induced mitation frequency that is 0.97 times the historical control frequency. For the $\sim 150,000 \mathrm{ppm}^{\circ} \mathrm{h}$ group, the corresponding and for the two exposure groups combined, it was 1.75. Eto thus appears to present a very wuch smaller risk for induction of gene mutations in stencell sperwatogonia than it does for other genetic endpoints induced in other types of cells.

\section{HERITABLE TRANSLOCATION AND DOMINANT-LETHAL MUTATION DOSE-RESPONSE STUDIES WITH INHALED ETHYLENE OXIDE}

$$
\begin{array}{ll}
\text { W. M. Generoso } & \text { J. B. Hoskins } \\
\text { K. T. Cain } & \text { J. R. Inman }
\end{array}
$$

Currently, there is considerable interest in the determination of the magnitude of the health hazard posed by inhaled ethylene oxide (Et0). Eto had earlier been shown to be capable of inducing chromosome damage in certain male germ cells. Short-tarm inha:-tion exposure to high concentrations of EtO, as well as 1.p. Injections of EtO, were found to Induce high levels of dominant lethals in postmelotic male germ cells of both rats and mice (Embree, J. W., Toxicol. App1. Pharmaco1. 40: 261-267, 1977; Cumming, R. B., Michaud, T. A., Environ. Mutagen. 1: 166-167, 1979; Generoso, W. M., et al., Mutat. Res. 73: 133-142, 1980). Even more important for its risk Impiication was our finding that 1.p.-infected Eto induces heritable reciprocal translocations in mice (Generoso, W. M., et al., Mutat. Res. 73: 133-142, 1980).

During the past year we completed portions of a study to determine the shape of the dose-effect curves for heritable translocations and dominantlethal mutations induced by inhaled EtO. This study will provide data for long-term exposures at $300,250,204$, and $165 \mathrm{ppm}$. Male 10- to 12-week old $(101 \times \mathrm{C} 3 \mathrm{H}) \mathrm{F}_{1}$ mice are being exposed 6 hours per day to Eto for a total of 11 weeks. For the first 8 weeks the exposures are being given cn the 5 working days, and then dafly for the last three weeks. Exposed males are mated during the 11th week of exposure (by being caged with females in the evening and exposed to ELO during the caytime) and for one to two weeks after the end of exposure.

Exposure cc parental mice, production of $\mathrm{F}_{1}$ progeny, and dominantlethal experiments have already been completed for 250,204 , and $165 \mathrm{ppm}$ concentrations. Testing of $F_{1}$ progeny for translocation heterozygosity 18 currently underway. Results avallable to date come from the dominantlethal studies. In matings that took place during the first week posttreatment, the Incidences of dominant-lethal mutations were $18 \%, 22 \%$, and $31 \%$ for 165,204 , and $250 \mathrm{ppm}$ concentrations, respectively. This result indicates that dominant-lethal mutations were induced at the three Eto 
concentrations and thit the responses appear not to deviate from a straight line.

1. Generoso, H. M., R. E. Cuming, A. J. Bandy, K. T. Cain, Increased douinant-lethal effects due to prolonged exposure of aice to inhaled ethylene oxide. Mutat. Res. 119: 377-379, 1983.

2. Sheu, C. H., R. T. Cain, R. M. Gryder, H. M. Generoso, Heritable translocation test with ethylene chlorohydrin in ale aice. J. Am. College Toxicol. 2: 221-223, 1983.

\section{NON-BREEDING-TEST METHODS FOR STUDYING INDUCTION OF DOMINANT SKELETAI MUTATIONS ARE EASILY APPLIED TO STRAIN USED IN SPECIFIC-LOCUS EXPERIMENTS}

$$
\text { P. B. jelby S. L. Niemann } 1
$$

In earlier non-breeding-test (NBT) experiments, the skeletons of $(\mathrm{C} 3 \mathrm{H} \times 101) \mathrm{F}_{1}$ alce were exanined. These mice were the offspring of unexposed $101 \mathrm{males,}$ or of 101 males that had been exposed to chemicals or radiation. A large-scale experiment of this type in which the exposure was to 239 plutonium is nearing completion.

Because the NBT methods depend strongly on an understanding or nonmutational and mutational variation in $(\mathrm{C} 3 \mathrm{H} \times 101) \mathrm{F}_{1}$ mice, it was uncertain whether these methods could be applied easily to another strain, specifically the mice used in specific-locus experiments. Nonetheless, it seemed especially worihwhile to test this possibility because of the large numbers of offspring that are always being produced in our section in specificlocus experiments.

The animals examined using NBT methods were drawn from the sample of mice collected by Hitotsumach1 et al. at our laboratory in a specific-locus experiment in which $(101 \times \mathrm{C} 3 \mathrm{H}) \mathrm{F}_{1}$ males were injected with either 300 or $400 \mathrm{mg} / \mathrm{kg}$ of ethylnitrosurea administered in $100 \mathrm{mg} / \mathrm{kg}$ fractions separated by a week. Only offspring derlved from treated stem-cell spermatogonia were studied. The frequencies of presumed dominant skeletal mutations following $0,3 \times 100 \mathrm{mg} / \mathrm{kg}$, and $4 \times 100 \mathrm{mg} / \mathrm{kg}$ of ENU were 2/374, 10/243, and 10/180, respectively. At both exposure levels, there 18 a highly statistically significant increase over the control frequency. The induced mutation frequencies at the two exposure levels are 3.5 and $5.0 \%$. At the higher exposure, the induced frequency of presumed mutations of a type likely to be of clinical importance is 4.5\%. The "indices of mutation" sere $0 \%$ in the control, $11.5 \%$ in the $3 \times 100 \mathrm{mg} / \mathrm{kg}$ group, and $12.4 \%$ in the $400 \mathrm{mg} / \mathrm{kg}$ group. In each case, the increase over the control is statistically significant. 
These results are especially importart to our Section because they show that the NBT wethods can easily be piggy-backed onto specifir-locus experiments in order to greatly increase the yield of data useful in estimating genetic risk that can be obtained fron a single experiwental group. A conbined experiment of this type will yield three independent measures of the frequency of wtations being induced, namely the specificlocus utation frequency, the frequency of presumed doninant skeletal utations, and the "index of mtation." The data obtained could be used for estinating genetic risk both by indirect (specific-locus data) and direct (skeletal data) wethods.

Earlier, we reported the Induction of doninant skeletal witations by a single exposure to $150 \mathrm{gg} / \mathrm{kg}$ of ENU. In that experiment we used the strain on which we have done wost of our skeletal research. Comparison of the results to those in the present experiment shows that the extent of induction in the two strains fits the expected dose response well. This is especially interesting in view of several important differences between the nice used in the two experiments. Hot only were the injected males derived from different strains, but they differed drastically as to the extent of heterozygosity, with those in the former experiment being inbreil and those in the present experiment being $F_{1}$ hybilds between two inbred strains (accordingly, still genetically uniform). Thus, either the strain difference or the extreme difference in degree of heterozygosity aight have caused then to have dissinilar atational responses.

The $F_{1}$ offspring whose skeletons were examined also differed greatly. In the forwer experiment, they were hybrids between two inbred strains and thus genetically uniform (unless wtations were present). In the present experiment, they had vastly wre genetic variability than that caused by mutations, because of the heterozygosity of their fathers and because their wothers were from a strain of nice that is not inbred.

The comparison of these experiments represents an important first step in the detailed investigation that is needed of how well one can eirrapolate the extent of induced genetic damage from one strain to another or, more importantly, from species to spectes. At least it is reassuring that this first comparison of different mouse strains by our methods shows good agreement in the yield of mutations.

1. Selby, P. B., Dominant skeletal mutations: applications in mutagenicity testing and risk estimation, in Heddle, J. A. (ed.): Mutagenicity, New Horizons in Genetic Toxicology, New York, Academic Pres8, 1982, pp. 385-406.

2. Selby, P. B., Applications in genetic risk estimation of data on the induction of dominant skeletal mutations in mice, in de Serres, F. J., and Sheridan, W. (eds.): Utilization of Mammalian Specific Locus Studies in Hazard Evaluation and Estimation of Genetic Risk, Noy York, Plenum Press, 1983, pp. 191-210. 


\title{
BREEDING-TEST EXPERIMENT SHOWS TRANSMISSION OF MANY ENU-INDUCED MUTATIONS
}

\author{
P. B. Selby \\ B. J. M. Whitt 8 \\ G. D. Rayner \\ T. H. McKinley, Jr.
}

Following the finding of the dranatically high wation frequencies reported in the preceding section, we decided to perform a smali experiment using the wch wre time-consuning breeding-test method in order to see if we could demonstrate the transaissibility of many of the presuned utations scored in the NBT (non-breeding test) studies. Altogetter $141 \mathrm{~F}_{1}$ ales were collected and given a chance to sire of fspring before they were killed and prepared for skeletal exanination. Of these, 114 came from the $4 \times$ $100 \mathrm{~m} / \mathrm{kg}$ sample of Hitotsunachi et al. and 27 fron the concurrent control.

Five of the 114 experimental wles were prfsumed mutants according to the criteria used in the NBT methods. Two cf these failed to sire any offspring even though they were paired with many females for many weeks. Thus: there was no possibility of confirming the transwissibility of their traits. A third male was shown to transwit a wutation having low (probably extrewely low) penetrance for a very severe effect. This male had scoliosis and fustons in the lumbar region and a grossly deformed left hind leg, Issing a fibula, cost of the tarsals, and two of the digits. One of his daughters was sinilarly, but more severely, affected. Thus far, no wre of his descendants have manifested the effect. Even with just 1 affected offspring, the frequency of the severe malformation was statistically significantly higher anong his total progeny than in the control, wth the result that he is confirmed to be a mutant. The remaining two presumed mutants are still being tested. If they transmit any abnormal1t1es, It seems apparent that the penetrance of these mutations will be incomplete. Based on our earlier work, it is likely that the skull fusions exhibited by both of these presumed mutants are caused by mutations with incomplete penetrance.

An Increase in the "Index of mutation" is expected only if dominant mutations are being induced that cause index anomslies. Many of the Index anomalies occur occasionally as nonmutant varjants. (The "index of mutation" in the control is zero because the control frequency of index anomalies is subtracted in calculating index values.) Twenty-three of the 114 experimental ales had at least one index anomaly, but none of the 27 control offspring had any. So far, 13 of the males having one or more index anomaly have been shown to transmit their effect, thus demonstrating 1ts mutational basis.

In addition, several anomalles that were not exhibited by presumed mutants, or that were not index anomalies, have been shown to be caused by mutations. Such mutations can be found by the breeding-test method becalise all unusual anomalles are tested for transmission even though the syndrome present 18 not suffictently unusual to meet elther the sensitive-1ndicator or multiple-anomaly-inferential criteria. 
When we finally complete this experinent, it is likely that the combined frequency of known mutant and untestable presumed mutant afce will be in the neighborhood of 18-20z. In contrast, the estimate of the induced frequency of presined dominant skeletal mutations of a type likely to have clinical inportance was found to be only $4.5 \%$ by NBT wethods. The excess of mations found in the breeding-test experiment consists largely of witations that are unlikely to adversely af fect health.

It will be Inportant to conduct mch larger breeding-test experiments on ace injected with ENU in order to further our understanding of the nature of the damage induced by this chenical. Little can be concluded about the numbers of sterile, fully penetrant, and only slightly penetrant wtations from such a small sanple of presumed witation, but should the relative numbers of each type come anywhere close to what was found, the contrast with radiation would be large, and the ratio of atation rates estimated from NBT and breeding test wethods would be different for the two mutagens.

A major advantage of NBT methods over the breeding-test wethod is that they are so mch faster. More important, the need for having methods that can identify serious mutations with low penetrance or mutations that cause sterflity is also fllustrated by this experiment. A method for studying the induction of dominant mutations that requires a test of transmission, such as the cataract test, would obviously overlook many important watations if a large number of those induced are simflar to the presirmed mutations found in this small breeding-test experiment. Huch of the burden of genetic disorders present in the human fopulation is irregularly inherited, and NBT wethods are essential if we are to make estimates of risk that fully account for irregularly inherited disorders.

DETAILED ANALYSIS OF RADIATION-INDUCED LITTER-SIZE REDUCTION IN SPECIFIC-LOCUS EXPERIMENTS

$$
\text { P. B. Selby W. L. Russel1 } 7
$$

A detalled analysis of the records from many past specific-locus experiments is in progress now that these data have been entered into ORN's PDP-10 computer. Many interesting facets of these data can now be explored that would have been much too time-consuming to examine earlier.

Our analysis of the extent of the litter-size reduction induced by radiation has been completed. The BEIR committee, In 1 ts 1980 report, recognized the importance of information on the litter-size reduction. They used the crude estlmate then avallable to demonstrate that the amount of damage from gross chromosomal mutaticis 18 much less than that from gene mutations. 
Our recently completed analysis of 14 radiation experiments involved approximately 900,000 litters. Comparisons were made between experimental groups and their concurrent controls in an attempt to cancel out seasonal differences and differences that ight occur in the stocks (ver the years. The nost inportant difference between the experimental and sontrol groups was in the age of the mothers when the litters were born. Maternal age greatly influences litter size, and it was unclear how much error crept into the earlier crude estinate because of some differences in experimental and control groups regarding the age of the dans. Accordingly, the age of the mother at the time of birth for each litter was calculated for all of the approxinately 900,000 litters. These ages were grouped into 50-day intervals, and conparisons of average litter size at weaning between experimentals and controls were made only between groups within the same interval.

It now appears that the litter-size reduction at $600 \mathrm{R}$ is 4.127 instead of our earlier crude estimate of 2.962, which was used by the BEIR Comittee. Although an adjustment for this new estimate would raise the BEIR estimate of the number of individuals having a serious handicap because of radiation-induced segmental aneuploidy from 0.35 to 0.49 per ntllion for I R of low-LET radiation, this analysis strengthens the view that these data clearly indicate that the risk from such Induced gross chromosomal damage among liveborn individuals is slight.

The relative litter-size reductions at various doses and dose rates in these early specific-locus experiments agree remarkably well both with relative specific-locus and with reciprocal-tra islocation mation frequencles. Thus, there is a humped,dose-response curve for $90 \mathrm{R} / \mathrm{min}$ radiation and there is a pronounced dose-rate effect. The valuable new measure of damage now made avallable with this analysis includes the total induced mortality before three weeks of age from all causes (segmental aneuploidy, trisomy, monosomy, gene matation, and $80 \mathrm{on}$, as well as dominant subvital mutations). These data strengthen the conclusion for radiation that there 18 much less genetic risk from chromosomal aberrations tian from gene mutation. They also show that at low dose rates there is very little dominant lethality induced by low-LET ionizing radiation.

\section{CYTOGENETIC ANALYSIS OF STERILE MALE PROGENY FROM MUTAGEN-EXPOSED PARENTS}

$$
\text { N. L. A. Cacheiro }{ }^{3} \text { C. V. Cornett }
$$

Approximately one-third of transmitted reciprocal translocations induced by lonizing radiations or alkylaing chemlcals in male postmelotic stages cause complete sterility in male progeny. The sterility is associated with blockage in spermatogenesis or spermiogenesis. Through detailed karyotype analysis we found that reciprocal translocations in sterile males often involved at least one breakpoint located close to a centromeric or telomeric region. (Cachelro, N. L. A., et al., Genetics 76: 73-91, 1974). 
In the past few years, we have been performing simflar analyses on sterile male progeny produced in various mutagenesis studies.

Effects of treatment of spernatogonia. One group of steriles was derived from Irrad ated spermatogonia. To date, we have analyzed a total of 54 sterile male progeny from this group. Out of these, 9 were carriers of reciprocal translocations, one was $X X Y, 10$ were $X Y Y$, one was $X Y / X Y Y$ mosalc, and one was $X 0 / X Y / X Y Y$ wosalc. Ho chromosomal abncrmalities were detected among the remaining 32 steriles. This result shows that, while practically all sterile male progeny derived from exposure of male postweiotic gern cells are carriers of reciprocal translocations, less than one-tenth of the eteriles derived from exposed sperwatogonia were found to carry reciprocal translocations. Furthermore, sex-chrowosome aneuploidy and sex-chromosone mosaicism contributed significantly to the cause of sterility in the spermatogonia group.

Effects of methylmercuric hydroxide. This experiment was conducted because of several reports that Indicated the ability of methylmercuric hydroxide to Induce chromosomal nondisjunction in Drosophila germ cells, and in plant and animal somatic cells. The present mouse study was designed to measure any Increase in the incidence of sex-chromosome aneuploids ( $X X Y$ and $X Y Y$ conditions are sterile) as a result of induced sex-chromosome nondisjunction in male or female germ cells. About 10-week old (SEC C57BL) $F_{1}$ females and $\left(101 \quad \mathrm{C}_{3} \mathrm{H}\right) \mathrm{F}_{1}$ males were randomized into experimental and conirol groups. In order to maximize the chance of detecting any mercury-induced effect, the maximum tolerated dose was used ( $4 \mathrm{ppm}$ in drinking water), and both males and females were exposed continuously, beginning at least two months prior to mating and until the progeny were weaned. This ensured presence of mercury in premeiotic, melotic, and postmeiotic germ cells, and in the progeny from conception to weaning. At sexual maturity, male offspring were tested for fertility, and sterile ones were analyzed cytologically.

In the mercury-exposed group, there were 17 steriles out of 1267 progeny tested (1.34\%), while in the control group there were three steriles out of 1262 tested $(0.24 \%)$. The difference is highly significant. Analysis of the 17 steriles from the mercury group revealed one XYY and 16 with no detectable chromosomal abnormalitles. The three steriles from the control group had no detectable chromosomal abnormalities. These data suggest that the mercury treatment was not effective in inducing sexchromosome nondisjunction in male and female melocytes. The significant increase in mercury-induced sterility among male progeny could be due to types of genet1c damage that are not detectable by the cytological techniques employed, or to nongenetic effects of mercury during the gestation and early postnatal perlods. 
RESPONSE OF MOUSE SPERMATOGONIAL STEM CELLS TO X-RAY INDUCTION OF HERITABLE RECIPROCAL TRANSLOCATIONS

\author{
H. M. Generoso \\ K. T. Caln \\ N. L. A. Cachetro ${ }^{3}$
}

C. V. Cornett

D. F. Cosslee 9

In wce, heritable translocations are an inportant endpoint with respect to evaluation of hazards from radiation-induced chromosomal aberrations. It 18, therefore, unfortunate that there has been a paucity of data on the rates at which heritable translocations are induced by ionizing radiations in spermatogonial stemcells, the stage of greatest importance in risk estination. Before the present study was completed, virtually no data were avallable for single doses up to $600 \mathrm{R}$; and for fractionated exposures, a wide range of values for the number of translocations per rad per gamete had been published (0.5 to $5.6 \quad 10^{-5}$ in the 1977 UNSCEAR Report), partly as a result of the small numbers of offspring tested in most studies.

The primary objectives of the present study were to obtain an accurate estimate of the number of heritable translocations expected per rad per gamete, and to determine how the rate of induction is affected by conditions of radiation exposure such as dose, dose-rate, and dose-fractionation. Furthermore, it was obviously important to obtain a fairly good estimate of the spontaneous frequency. All these objectives (except for dose-rate studies) have been fulfilled. First, we have obtained a good estimate of the shape of the heritable-translocation dose-effect curve for spermatogonial stemcells. Doses of $150,300,600$, or $1200 R$ of acute $X$ rays were used. The ascending portion of the "humped" dose-effect curve fits the linear model very closely. Second, the frequencies of heritable translocations observed in the $600 \mathrm{R} 2$ and $500 \mathrm{R} 4$ fractionation experiments appear to be within reasonable bounds of what might be expected from additivity. And thirdly, we have obtained the most reliable figure to date for the spontaneous frequency of heritable translocation; based on 5433 tested of fspring, this frequency was $1.8 \quad 10^{-4}$.

The linearity of the ascending portion of the dose-effect curve, the additivity of effects observed in the dose-fractionation experiments, and the reliable control rate permit a direct calculation of the rates of induction of heritable translocations per gamete per rad of acute exposure. At $1200 \mathrm{R}$ single exposure, the rate $1 \mathrm{~s}$ clearly lower than at other doses; this point lies at the tall end of the descending portion of the humped dose-effect curve. All other values, on the othe: hand, are very close to one another, tanging frow $3.07 \quad 10^{-5}$ to $4.44 \quad 10^{-5}$, with no significant differences among them. On the basis of this linear portion of the curve, the average number of translocations per rad per gamete, weighted by the reciprocal of the vartances, is estimated to be $3.890 .2510^{-5}$.

In another radiation study on spermatogonia, we are attempting to provide information that should clear up some of the confusion on the 
relation between the frequency of reciprocal translocations scored cytologically in meiocytes of exposed males and the heritable translocation frequency scored in offspring. The latter is, on the average, only half of what is expected on the basis of the former, and there is a lack of consistency in the ratio of cytologically to genetically scored translocations. It has been suggested that the discrepancy could be attributable to selection during postmelotic stages against translocation-carrying ganetes, or to metaphase-I lelay (i.e., spermatocytes carrying translocations wht take longer to pass through metaphase I) that results in a spuriously elevated cytological frequency. We are estimating the actual proportion of unbalanced segregants by conducting a sizable dominant-lethal experiment simultaneously with a cytological study of melocytes of the males that are used as sires. The optimum dose for this combined study, $4 \times 500 \mathrm{R}$, was chosen on the basis of the results of the translocation experiment described above. With this treatmert to spermatogonia we expect a dominant-lethal-type ef iact of about $20 \%$ from unbalanced segregants of reciprocal translocation.

1. Generoso, W. M., Cain, K. T., Cacheiro, N. L. A., Cornett, C. V., Response of mouse spermatogonial stem cells to $X$-ray induction of heritable reciprccal translocations. Mutat. Res., in press.

DNA TARGET SITES ASSOCIATED WITH CHEMICAL INDUCTION

OF DOMLNANT-LETHEI MLTATIONS AND HERITABLE TRANSLOCATIONS IN MICE

\author{
W. M. Generoso J. B. Hoskins \\ K. T. Cain
}

Chromosomal aberrations that lead to early lethality among conceptuses do not contribute to the population's genetic burden. On the other hand, aberrations that permit survival and reproduction can have untoward effects on carriers, as well as on some of their immediate descendants. How these two classes of aberrations are produced in mammalian germ cells has been the objective of our long-term study.

In mice, dominant-lethal mutations and heritable translocations best exemplify the nonviable and viable endpoints of chromosome breakage induced in germ cells. In males, Induction of these endpoints is stage dependent, and the sensitive stages vary from one mutagen to another. Both endpoints are induced by certain alkylating chemicals in male meiotic and postmelotic germ cells, but the relative rates at which they are induced is lependent upon the alkylating chemical. The recent completion of the ethyl nitrosourea (ENU) and methyl nitrosourea (MNU) studies enabled us to relate certain DNA adducts with the production of dominant-lethal mutations and heritable translocations. 
Among compounds that have been studled in our laboratory, isopropyl methanesulfonate (IMS) and ENU were found to be effective in inducing dominant-lethal mutations, but these chemicals induce very few heritable translocations in the same germ-cell stages. By contrast, ethyl methanesulfonate (EMS), methyl wethanesulfonate (MMS), triethylenemelamine (TEM), ethylene oxide (Et0), MNU, and cyclophosphamide are all ef fective in inducing both endpoints. This suggests that IMS- or ENU-1nduced primary lesions that result in dominant-lethal mutations are different from the lesions that result in heritable translocations. In other words, the simple interpretation that the same mechanism is responsible for the randon production of donl nant-lethal mutations or heritable translocations is not always correct.

We have postulated that the production of dominant-lethai mutations and heritable translocations is determined by the stability of alkylation products in the chronosomes. If these products are intact in the male chromosomes at the time of sperm entry, they may be repaired in fertilized eggs. If repafir is not effected and the alkylation products persist to the time of pronuclear chromosome replication, they lead to chromatid-type aberrations and eventually to dominant-lethality. The production of heritable translocations, on the other hand, requires the transformation of unstable alkylation products into sultable intermediate lesions. These lesions are then converted into chromosome exchange (both symmetrical and asymetrical) after sperm enters the egg but prior to the time of pronuclear chromosome replication (1.e., chromosome-type). Thus, dominantlethal mutations result from both chromatid- and chromosome-type aberrations, while heritable translocations result primarily from the latter type.

Our findings with ENU and MNU not only strengthen the above conclusions, but they also contribute to the following interpretation regarding the DNA adducts involved. The chemicals that are effective in inducing heritable translocations (EMS, MMS, MNU, and EtO) alkylate primarily the N-7 position of guanine. The chemicals that are ineffective in inducing heritable translocations but are effective in inducing dominant-lethal mutations (IMS and ENU) alkylate primarily the oxygen of the phosphate backbone (forming phosphotriesters) and of bases, e.g., the 0-6 position in guanine; very little alkylation occurs at nitrogen positions. Consistent with the stability interpretation, $\mathrm{N}-7$ alkyl guanine adducts are not stable and are lost via hydrolysis, resultinr, in the formation of apurinic sites. Alkylation products with oxygen of buses and phosphotriesters, on the other hand, are highly stable. Thus, heritable translocations ure associated with unstable N-7 alkylguanine and, possi:ily, with $\mathrm{N}-3$ alkyladenine as well, since the latter product is also highly unstable.

1. Generoso, W. M., Cain, K. T., Bandy, A. J., Role of fertilized eggs in the formation of chromosome aberrations in mutagen-treated germ cells of male mice. Progress and Topics in Cytogenetics, Alan R. Liss, Inc. New York, In press. 


\section{EARLY GABRYONIC LETHALITY INDUCED BY SEED OLLS IN FEMALE MICE} TREATED PRIOR TO INSEMINATION

\section{W. M. Generoso \\ J. B. Hoskins}

R. T. Cain

W. J. Washington 10

In animal carcinogenicity and toxicity tests, corn oll is often used as the carrier of test substances that are insoluble in water but soluble in various fat solvents such as ether, chloroform, or benzene. He have been using corn ofl as the carrier of coal-derived mixtures in short-term dominant-lethal and long-term total-reproductive-capacity tests. In the coirse of one dominant-lethal study on females injected intraperitoneally with a coal mixture dissolved in $0.4 \mathrm{ml}$ corn ofl, we noticed an unusually high incidence of deciduomata in the control group (which had received $0.4 \mathrm{ml}$ of corn o11). Because the strain of females used, (SEC $\times$ C57BL)F 1 , has in the past shown consistently low levels of deciduomata in control groups treated with Hanks' Balanced Salt Solution, UBSS, we decided to test corn ofl for induction of early embryonic lethalfiy in created female mice.

Virgin females 10-12 weeks old, from strains (SEC $\times$ C57BL) $F_{1},($ C3H $\times$ C57BL $) F_{1}$ and $(\mathrm{C} 3 \mathrm{H} \times 101) \mathrm{F}_{1}$, were given a single 1.p. injection of $0.4 \mathrm{ml}$ corn ofl (cold pressed). Control mice were injected with $0.4 \mathrm{ml}$ of HBSS. All females were mated during the 6 days following injection and killed for uterine analysis 12 to 15 days after mating. The corn ofl-treated groups had up to $30 \%$ deciduomata (all three strains were affected), while none of the control groups had more than $5 \%$.

To determine whether other ofls might produce a similar effect, we tested $0.4 \mathrm{ml}$ single 1.p. injections of peanut oil, sesame oil, ollve oil, or mineral ofl in (SEC $\times$ C57BL) $F_{1}$ females. All three plant ofls were found to increase the Incidence of deciduomata. Mineral ofl, on the other hand, had no ef fect whatsoever.

To determine whether the corn-oil action was affected by route of administration, we compared the effects of $0.4 \mathrm{ml}$ or $0.8 \mathrm{ml}$ corn ofl given orally with those of $0.4 \mathrm{ml}$ corn ofl $1 . \mathrm{p} .$, or $0.8 \mathrm{ml}$ HBSS given orally. Results clearly showed that the oral administration of corn ofl did not increase the incidence of deciduomata above contr.1 levels.

Thus, 1.p. Injection of corn o1l, but not oral administration, markedly increases the incidence of deciduomata, and a similar effect 18 observed with three other seed ofls, but not with mineral oil. This reproductive response to seed olls was surprising in view of the general belief that these substances are nontoxic. It will be of considerable interest to determine the basis for th1s response. Because females were treated, early embryonic lethality may be due to direct effects on oocytes or embryos, or to maternal-environment effects associated with alterations in female physiology. We are following up on this problem.

It should be noted that seed o1ls, as well as mineral ofl, are metabolized and eliminated from the peritoneal cavity very slowly. Traces 
of the oils in the peritoneal cavity can be detected 10 days or more after infection. The most promising lead, at this point, is the observation that in a good number of corn ofl-treated females that were killed for uterine and ovarian analyses, the number of implantation sites was clearly higher than the number of corpora lutea. In other words, there were wore enbryos implanted than could be accnunted for by the number of ovulation sites. This observation seems to suggest that $c_{-}=\mathrm{n}$ ofl, or a metabolite, interferes with the normal processes of polar-body extrusion and fertilization (e.g., a polar body may be fertilizad) and/or with early cleavage stages. The ovaries and oviducts, which are surrounded by fatty tissues, are located in the peritoneal cavity. It is likely that the slow elimination of corn ofl from the peritoneal cavity allows the exposure of oocytes and eggs to the ofl and its metabolites during divisions. Such exposure is not possible when ofl is administered oraliy.

Investigation of the effects of corn ofl on welotic anc early cleavage divisions is in progress. The almost universal human use of seed olls warrants a thorough investigation of their biological effects. Because of the problems in getting the oil (which cannot be delivered in aqueous media) to target cells, such studies are difficult in in vitro and many In vivo systems.

\title{
A RESTUDY OF THE EFFECTIVENESS OF INGESTED ETHYL ALCOHOL TO CAUSE NONDISJUNCTION IN MOUSE OOCYTES
}

\author{
W. J. Washington 10 \\ N. L. A. Cacheiro ${ }^{3}$ \\ W. M. Generoso
}

Trisomies, which result from nondisjunction, play a major role in human spontaneous abortions and genetic disorders (e.g., Down's Syndrome). A recent report by $M$. H. Kaufman (Nature 302: 258-260, 1983) on the Induction of chromosomal nondisjunction by ethanol present at conception in mice thus attracted considerable attention. Since all autosomal monosomies and several trisomies are lethal by day 12 in the mouse, we anticipated that Kaufman's treatment, which 18 reported to have caused about $20 \%$ aneuploidy (monosomy + trisomy), should result in a detectable amount of embryonic death. Accordingly, we Investigated the dominant-lethal response of female mice given ethyl alcohol crally shortly after mating. We also conducted a corresponding cytological analysis of the first postfertilization metaphase prior to first cleavage division.

In the dominant-lethal study, the mating procedure was designed so that the time of fertilization in relation to the time of treatment was known. Males and females were caged together for 30 minutes each morning beginning shortly after the start of the light period. As determined in previous studies, the ovulated eggs are already in the ampullae at this time. Females were checked for the presence of vaginal plugs at the end of the mating period, and were given, via oral intubation, $1 \mathrm{ml}$ of $12.5 \%$ 
ethanol or distilled water, eit'er 1.0 or 1.5 hours after the end of mating period. (We had found in an earlier study that sperm entry into the egg starts abc 1 t 1.75 hours after the end of such a mating period.) Females were $k 11$ id for uterine analysis 12 days after mating.

In the cytological study, the females were superovulated by injection with 5 I. U. of pregnant mare serun (PMS) followed 48 hours later by 5 I. U. of human chorionic gonadotropin (HCG). Immediately after injection of HCG, fenales were caged with males overnight. Those which had vaginal plugs the next worning were given either 1 nl of $12.5 \%$ ethanol or 1 nl of distilled water orally at 13.5 to 14.5 hours after HCG (1.e., about 1.5 2.5 hours after the expected tine of ovulation). Since spera entry starts about 1.75 hours after mating, the oocytes were in the process of conpletIng the second meiotic division at the time of treatment. (Kaufman administered ethyl alcohol 13.5 hours after HCG.) Mated females were injected Intraperitoneally with $2.5 \mathrm{mg} / \mathrm{kg}$ of colchicine 9-10 hours after ethanol adninistration and were killed the following morning (about 15 hours after colchicine treatment). Eggs were flushed from the oviduct and prepared for cytogenetic analysis. In all cases, only one egg was fixed per slide. The slides were coded and scored without knowledge of their derivation.

In the dominant-lethal study, the frequency of embryonic death in the ethanol-treated group was not significantly higher than that in the control group. Similarly, the cytological findings on superovulated eggs did not indicate a significant ethanol-related increase in aneuploidy. Thus, our results to date do not suggest an induced nondisjunctional response. Close comparison with Kaufman's results is, however, not possible because of strain differences and other factors. Most important, our dominant-lethal study must be expanded to include a later age at sacrifice, since several mouse trisomies cause death after the 12th day of gestation, the stage for which the present results were obtained. Such a study is in progress.

1. Chu, E. H. Y., (jeneroso, W. M. (eds.): Proceedings of the International Workshop on the Principles of Environmental Mutagenesis, Carcinogenes's, and Teratogenesis, May 25-June 1, 1983, Shanghal, The People's Republic of China, New York, Plenum Publishing Corp., in press.

DEVELOPMENT OF TESTS THAT DETECT INDUCTION

OF MEIOTIC NONDISJUNCTION IN MAMMALS

Liane B. Russell

Commonly used mammalian germline mutagenesis tests do not detect numerical chromosome anomalles per se (that 18 , aneuploidy caused by $\mathrm{mls}$ segregation as opposed to chromosome breakage and rearrangement). Because 
trisomic offspring can bring considerable grief to human fanilies (e.g., Ts21 which causes Down's syndroue), tests that detect nondisjunction inducers should be developed. A literature search was cariled out for the purposes of surveying and comparing techniques that have been used to detect miotic nondisjunction in experimental mamals, and of designing the potentially wost informative studies.

The discovery in recent years of wuse populations carrying Robertsonian translocations that, in the aggregate, involve all chromosomes has provided tools for the systematic study of the phenotype of animals trisonic or monosonic for any given chromosome. The method, which involves a cross in which one parent carries two Robertsonian translocations having one common arm [e.g., $\mathrm{Rb}(1.15)$ and $\mathrm{Rb}(3.15)]$, has shown that (a) all trisomics in the mouse die after midgestation, (b) none of the autosomal trisomies regularly survives birth (though some do so occasionally), and (c) some have worphological phenotypes that are externally recognizable during fetal stages. All monomics, except $X 0$ (which survives to adulthood), die preimplantation or shortly postimplantation.

The methods that have been used for the detection of trisomics in experimental mammals differ in the developmental stages examined, the type of analysis, and the signal for trisomy. (a) Chromosomal analysis at the first melotic metaphase (M I) (signa1: low chlasma frequency; univalents) is presumed to predict the occurcence of nondisfunction (ND) in $M I$. (b) Chromosomal analysis in M II (signal: extra dyads) can detect ND that occurred in M I. (c) Fluorescence studies of spermatids or sperm (signal: extra fluorescent bodies presumed to be sex chromosomes) could detect ND from $M I$ and/or $M$ II. (d) Chromosomal analysis in the zygote (first cleavage) can show extra chromosome(s) in the waternal or paternal complements, which can of ten be distinguished (origin: ND in $M I$ and/or $M$ II of either parent). (e) Chromosomal analysis of several cells of morulae, blastocysts, or midgestation embryos, if it shows consistent hyperploidy, can reveal ND in melosis of elther parent. Similar studies on newborns are now seen to be largely useless in view of the generally prenatal death of trisomics. (f) Postnatal analysis using genetic markers. This may consist of the numerical sex-chromosome anomaly test (developed by us some time ago); or, to detect autosomal $\mathrm{ND}$, a method in which complementing ND segregants from translocation parents are recognizable. (g) Postnatal analysis using a preliminary fertility test, followed by cytological analysis of oterijes to determine whether some are XXY or XYY. This method is a product of the usual Heritable Translocation Test.

A11 of these methods have certain drawbacks and certain advantages, which were enumerated during the study. It should be noted that trisomics detected by methods (e) through (g) could, at times, be the result not of meiotic ND, but of mitotf.c ND in the embryo. The complementary morosomic cell IIne presumably died at an early stage. Chance cell sampling, or, alternatively, chance assortment of the trisomic line into inner-ce.1-mass (as opposed to trophoblast) of the blastocyst could lead to fallure to detect original mosaicism. 
One method that has not yet been used, and which wo ho to explore, involves analysis during fetal stages, at which tine most trisonics are now known to die. The signals would be fetal growth retardation and worphological anomalies, to be verified by cytological analysis.

The stage at which an agent is wost likely to induce ND depends, in our opinion, on the mechanism by which ND is thought to occur. If the underlying cause of $\mathrm{ND}$ is a reduction in genetic recombination, the agent should be applied during premelotic DNA synthesis (34-36 days preejaculation in the mals; half-way during intra-uterine life in the female). If, on the other hand, the agent acts on spindle forcation or function, the sensitive stage is probably M I and M II (22-23 days pre-ejaculation in the male; ca. one-half day preovulation in the female). Agents acting on the kinetochore be active throughout melotic prophase, maphase, and anaphase.

Among chemicals that appear to have produced trisomy by motic ND in mammals are agents that act on DNA (EMS, MAS, 6-Mercaptopurine, and possibly cyclophosphaside), agents that act on the spindle (colchicine), and agents with largely unknown action (cadmium chloride, halothane, certain hormones). It is noteworthy that agents of the first group gave positive results when applied to preleptotene stages of spermatogenesis.

\section{EVALUATION OF EXISTING MUTAGENICITY BIOASSAY FOR PURPOSES OP GENETIC RISK ASSESSMENT}

Liane B. Russell

It must be assumed that there is a high probability of genet1c hazard to human befings if mutation induction can be demonstrated in the germline of experimental mammals. However, for a large percentage of chemicals, mamalian germline (MG) mutation data do not yet exist, and efforts to Identify possible genetic hazard must be based on results from other tests. An attempt was made to evaluate the degree of reliability with whish varlous types of data may accomplish this task. Two approaches were used. (1) A weighting scale was devised, based on major parameters by which the conditions of an assay resemble or differ from those encountered in the Induction of transmitted genet1c damage in mammals. (2) Findings from each of two standard MG tests were compared with those from each of the other assays in turn, and correlations calculated.

The first approach was complicated by the circumstances that (a) for over $85 \%$ of the 2367 chemicals in the Gene-Tox data base results are avallable in only one or two test categories, and (b) MG tests have in the past been performed preferentially on chemicals that had already been shown to be mutagen1c in other systems. In comparisons with two separate MG tests -- specific-locus test (SLT) and herftable-translocation test (HTT) -- no positive MG results were found for chemfcals that scored low with 
regard to weighted results for non $M$ tests. On the other hand, sone negative MG results were found for high-scoring chenicals.

The second approach was conplicated by the circunstance that there was only a liwited number of cases in which the particular MG and non-HG tests being compared had enough chenicals in comon to me the comparison maningful. A cut-off point as low as ten comen chenicals had to be chosen. Each observed MG-non-HG concordance was compared with a random assortment of outcones, calculated on the null hypotiesis, for the sase pair of tests. The observed outcone was found to be wost elevated over randon expectation when MG results were conpared with some of the mamalian in vivo tests (e.g., unscheduled DiA synthesis in the testis, wouse spot test); but, because of the low numbers of shared chenicals, none of the differences was statistically significant.

The data base as it stands can be utilized to identify genetic hazard If a positive MG result is avallable, or if the non-HG score (using the welghting system) is high. It cannot be used to assess risk, but it can help to establish priorities for choosing cheaicals on which to proceed to various lengths along the path to risk assessment. Such priorities ust be based in part on the expected agnitude of genetically significant exposure. A decision atrix for this purpose was devised.

[This analysis was perforwed in the context of evaluating the Cene-Tox data base. The assistance of EMIC in this endeavor is gratefully acknowledged.]

\title{
CHEMICAL DOSIMETRY STUdIES IN MAMAALIAN GERM CELLS
}

\author{
Gary A. Sega \\ Amy E. Jetton ${ }^{3}$ \\ Helen R. Harvey ${ }^{11}$
}

James G. Owens

Susan C. Hansler ${ }^{12}$

Chemical dosimetry using radicactively labeled chemical mutagens provides ir.portant information about the wolecular events going on within germ cells after mutagen treatment. It is an extremely sensitive procedure and can be used to measure binding of chemical agents to germ cells and to gern-cell ONA at exposure levels that are orders of magnitude lower than those needed to produce a statistically significant genetic effect. As our dosimetry data are combined with other genetic and cytogenetic data using the same chemicals, we shall learn much more about the relationship between the extent of chemical damage in the germ cells and the amount of genetic damage expected at realistic exposure levels for humans.

Following the finding by $W$. L. Russell that ethylnitrosourea (ENU) is a very powerful mutagen in manmalian germ cells, we initlated studies of the blochemical interactions of this chemical with gorm cells in the male

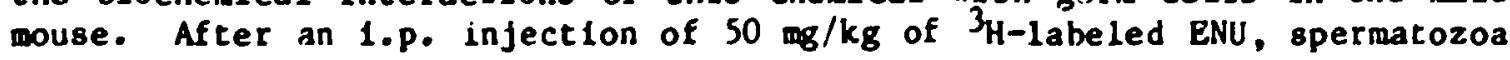


have been recovered fron the vasa deferentia of exposed males over a 28-day tine periud. The alkylation pattern observed in the diveloping spere showed about a two-fold greater level of spere-head ethylation 8-14 days after treatment than at earlier or later time points. This Indicated that late spernatid to early spermatozoal stages were being alkylated somewhat wre than the other wototic and postmelotic gern-cell stages. However, the Increase in alkylation of late spernatid to early spermatozoal stages by ENO is very suall compared to the Increase seen in the same stages when methyl methanesulfonate (MIS) or ethyl methanesulfonate (EMS) are used. With these chenicals there 18 an elght- to ten-fold Increase in the alkylation of late spernatids to early spermatozoa, due to Incre.18ed alkylation of sperm protanine In those stages. It appears that chenicals like ENU and its hosolog, methylnitrosourea (INU), which react by an $S_{l l} 1$-type mechanism, interact wch less with sperm protanine than do chenicals like wS and ENS that react by an $S_{N^{2}}$-type mechanisin.

In studying the presence of DWA alkylation products in the testes after different exposures to ENU, we found that the ratio of $0^{6}$-ethy1guanine $\left(0^{6}-E G\right)$ to $N-7$ ethylguanine (N-7 EG) changes with exposure level. Thus, after a $100 \mathrm{mg} / \mathrm{kg}$ ip injection of $\left[{ }^{3} \mathrm{H}\right] \mathrm{ENU}$, the $0^{6}-\mathrm{EG} / \mathrm{ll}-7 \mathrm{EG}$ ratio in testicular DNA 18 around 1.1 , but as the exposure 18 lowered to $10 \mathrm{mg} / \mathrm{kg}$, the $0^{6}-\mathrm{EG} / \mathrm{N}-7 \mathrm{EG}$ ratio reaches a value of 0.7 . Since $0^{6}$-EG is belleved to be an inportant mutagenic lesion sn DNA, the changing proportion of this lesion measured in testis DNA as a function of chemical expcisure level can be an inportant point to consider when interpreting genetic tests. Mutation frequencies obtalned at high chemical exposure levels may not extrapolate linearly as chemical exposures are lowered.

1. Sega, G. A., Owens, J. G., Methylation of DNA and protanine by methy1 methanesulfonate in the germ cells of male wice. Mutat. Res., In press.

\section{DNA REPAIR STUdIES IN MAMMALIAN GERM CELLS}

$$
\text { Gary A. Sega James G. Owens }
$$

In submammalian test systems, nitrosocarbamates are 100-fold more mutagenic than are thelr corresponding nitrosourea homologues. Since ethyl nitrosourea proved to be such a powerful mutagen in the mouse, $W$. $L$. Russell has performed a specific-locus experiment using nftrosoethyl carbamate (NEC). While NEC has shown moderate to high wutagenic activity in the mouse, it is considerably less potent than ENU.

To learn more about this chemical's interaction with germ-cell DNA in the mouse test1s, $(101 \times \mathrm{C} 3 \mathrm{H}) \mathrm{F}_{\mathrm{I}}$ males (the same stock being used in the genet Ic experiments) were given i.p. Infections of NEC. The exposures were 
100 and $300 \mathrm{gg} / \mathrm{kg}$. Testicular injections of $\left[{ }^{3} \mathrm{H}\right] \mathrm{dThd}(18 \mathrm{\mu Ci} /$ testis) were given along with the NEC. In an additional experiment, the NEC was injected directly into the testes along with the $\left[{ }^{3} \mathrm{H}\right] \mathrm{dTh}$. The concentration of NEC was such that, for an average testis weight of $100 \mathrm{mg}$, the dose was $300 \mathrm{mg} / \mathrm{kg}$. Sixteen days after trentment, sperm were recovered fron the caudal epididymides and assayed for an unscheduled-DHA-synthesis (UDS) response using liquid scintillation ccunting. (The spera sampled at this time weie primarily in early spermatid stages at the time of treatment.)

Historical control values have averaged 10 disintegrations per winute (DPM) $/ 10^{6}$ sperm. With the 100 and $300 \mathrm{mg} / \mathrm{kg} 1 . \mathrm{p}$. Injections of NEC, we obtained an average of 11.4 and $17.1 \mathrm{DPH} / 10^{6}$ sperw. The direct testicular injection of $\mathrm{NBC}$ resulted in $24.5 \mathrm{DPM} / 10^{6}$ sperm. The UDS response is marginal at best. The sonewhat larger response from direct testicular injection of NEC may be attributable to fallure of blood esterases to Inactivate all of the NEC before it had an opportunity to alkylate some germ-cell DNA. He have now studied the ability of about 20 different agents to induce a UDS response in germ cells of the male mouse. There has been a very good correlation between those agents which give a positive UDS response and those which give a positive specific-locus test in the same germ-cell stage. The only exception may be hycanthone methanesulfonate, for which we obtained a weakly positive UDS effect ( 2 to 3 times control values) but which was negative in the specific-locus test. Other agents showing a positive UDS effect in mouse germ cells include methyl-, ethyl-, propyl-, and isopropyl methanesulfonate, cyclophosphanide, mitomen, ethylene oxide, methylnitrosourea, ethylnitrosourea, triethylenemelamine, and $X$-rays. Agents that have been negative in the UDS test include ethylene dibromide, dimethyl nitrosamine, diethyl nitrosamine, benzola]pyrene, caffeine, methyl nitrosoguanidine, and mitomyc:n C.

1. Sega, G. A., Kelley, M. R., Owens, J. G., Carricarte, V. C., Caffeine pretreatment enhances the unscheduled DNA synthesis in spermatids of mice exposed to wethyl wethanesulfonate. Mutat. Res. 108: 345-358, 1983.

2. Sega, G. A., DNA repair in spermatocytes and spermatids of the mouse, in Bridges, B. A., Butterworth, B. E., Weinstein, I. B. (edz.): Banbury Report 13 , Indicators of Genotoxic Exposure, Cold Spring Harbor Laboratory, NY, 1982, pp. 503-513. 
DAA DAMAGE IN Mamalian SPERM ASSAYEd BY ALKALINE ELUTION

\author{
Gary A. Sega \\ Janes G. Owens
}

Estela Generoso

To further assess the danage produced in mamalian gern cells by wodel chenicals, we are continuing to develop an alkaline-elution procedure to measure DNA strand breaks in spermatozoa. The procedure involves the lysis of the germ cells after treatwent with the test chenical, followed by separation of the DNA double helix using a strong base. Any swall pieces of single-stranded DWA resulting fron breakage by the test chentcal will rapidly pass through a filter, while noral-sized INA will take wch longer to pass thrcugh the same filter. This procedure my prove especially useful in looking for the accumulation and/or persistence of DNA strand breaks In mature spern stages where no UDS (DMA repair) is observed after wtagen treatment. It is hoped that this method of detecting DNA damage in mose spern my eventually prove to be a useful means for montoring DaA danage in human sperm.

The germ-cell DNA of a group of $(\mathrm{C} 3 \mathrm{H} \times 10 \mathrm{I}) F_{1}$ hybrid males was labeled

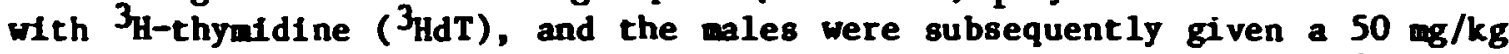
1.p. Injection of MS. (Our original studies had used $100 \mathrm{mg} \mathrm{MMS} / \mathrm{kg}$, but to avold any possible toxic effects to the gera cells, we decided to lower the MS exposure to $50 \mathrm{mg} / \mathrm{kg}$.) A second set of $(\mathrm{C} 3 \mathrm{H} \times 101) \mathrm{F}_{1}$ males had their gern cell DNA pre-labeled with ${ }^{14} \mathrm{CdT}$ and served as controls.

At dally intervals through 21 days after MS treatment, spermatozoa from the vasa deferentia of treated and control animals were placed together on polycarbonate filters and lysed DNA was eluted through the filter overnight, using an alkaline buffer at pH 12.2. The imounts of treated and control DNA eluted through the filter were determined using liquid scintillation counting techniques. In the first week following MS injection the amount of sperm DNA that eluted increased gradually. Maximum DNA elution was found for sperm collected 7 to 14 days after exposure. In this time period the amount of elution was 20-25\% greater from treated than from control DNA.

Genetic tests with MS in the mouse have shown that sperm sampled in the second week following treatment (early spermatozoa to lace spermatid stages at the time of treatment) show the highest frequency of dominant lethals and specific-locus mutations. There is, moreover, good agreement between the pattern of genetic effects produced by MS in the developing sperm and the pattern of DNA elution that we have measured.

Similar work is in progress with ethylene oxide (Et0), a widely used Industrial chemical and sterilant. After a $100 \mathrm{mg} / \mathrm{kg}$ i.p. Infection of Eto the same sperm DNA elution pattern was observed as when MS was used. (MMS and Eto have nearly identical Swain Scott 8 values, which means that both chemicals should attack the same nucleophilic sites in DNA and proteins.) 
The genetic pattern of Induced doninant lethallty produced by Eto in developing wouse sperm shows a peak effect in sperm sampled in the second week posttreatment. This is correlated with our highest elution values for the Eto-exposed sperm DNA. There is overall good agreement between the pattern of genetic effects produced by EtO in developing sperm and the pattern of DNA elution that we have measured.

Possibly the nost inportant finding in our work to date is that we can use alkaline elution procedures to measure DNA damage in mamallan sperm with at least some classes of chemicals. In the case of MS and EtO, there is a good correlation between the pattern of DNA elution in the developing spers of treated nice and the pattern of induced genetic damage. The possibility, therefore, exists for using the alkaline elution procedures we have developed in the mouse to monitor human spern for DNA breakage that may be correlated with genetic damage.

\section{ANALYSES OF SPECIFIC REGIONS OF THE MOUSE GENOYE}

Liane B. Russell

Jane Mendel 1

C. S. Montgomery

Lorraine Albritcon 1

In a continuation of our detailed genetic analysis of specific chromosomal regions of the mose, we have initiated a study of mitations involving the $p$ (pink-eye) locus. Like the $c$ (albino) locus analyzed by us earlier, $P$ is on Chromosome 7, about $14 \mathrm{cM}$ proximal to c. Over $170 \mathrm{P}$-locus mutants have been analyzed as to heterozygous and homozygous phenotype and mode of origin (type of wutagen and germ-ceil stage of induction). A complementation experiment has been initiated with about 50 of the mutations. (In the case of our c-locus study, complementation analysis allowed us to Identify 12 complementation groups that are probably overlapping small deficiencles involving the marker locus.) Although still in early stages, the p-locus study has already revealed some complementations for lethal effects. We are presently developing a computer program that will facilitate analysis of weaning weights and longevity in offspring of the many crosses of the matrix.

About 40 p-locus mutants are in process of being tested for possible deficlency for ru-2, a marker that is 2-3 oM proximal to $p$. One such deficlency has been found. A number of $P$ locus lethals have also jeen screened for lactate-dehydrogenase-A expression by gel electrophoresis, followed by measures of enzyme activity. The $p$ mutant that 18 deficient for ru-2 was found to be deficient for Ldh $A$ as well. This mutant was, however, not deficient for X1d (xylose dehydrogenase), which 18 probably proximal to ru-2. Work has begun on cloning mouse Ldh-A. The clone wlll be useful in determining the coding sequence of the gene and in studying the regulation of the gene's expression (LDH-A is regulated both developmentally and in a tissue-specific manner). The genomic clone may also become useful as an 
entry point into the region surrounding the $p$ locus (defined by $p$-lethal deficiencies).

In earlier years we had genetically analyzed the d-se region in Chromosome 9, using a large series of radiation-induced d, se, and d se witations. A recent enlargenent of this study indicates that, in contrast to the findings for the c-locus region, many mutions in the $d$ region cannot be fitted into any 1 inear order. We have initlated a collaborative study with Nancy Jenkins and Neal Copeland, who recently found that the original spontaneous mitation tc d ( $>50$ years ago) resulted from integration of an ecotropic murine leukenla virus into the DNA of Chromosome 9, presunably at the d locus. We are supplying spleens from a large number of genetically analyzed d-se-region mutants for restriction analyses, the results of which we shall jolntly attempt to correlate with the genetic findings.

1. Russell, Liane B., Qualitative analysis of mouse specific-locus mutations: Information ongenetic organization, gene expression, and the chromosomal nature of induced lesions, in de Serres (ed.): Specific Locus Studies in Hazard Evaluation and Estimation of Genetic Risk, New York, Plenum Pres8, 1983, pp. 241-258.

2. Stelzner, Kathren F., Four dominant autosomal mutations affecting skin and hair development in the mouse. J. Heredity 74: 193-196, 1983.

SYNAPTONEMAL COMPLEX STUDY OF NONHOMOLOGOUS SYNAPSIS

IN $X$-AUTOSOME TRANSLOCATIONS SHEDS LIGHT ON $X-Y$ DISJUNCTION MECHANISMS

$$
\text { T. Ashley } 3 \text { L. B. Russe11 }
$$

Electron microscopy of pachytene nuclel of male mice heterozygous for either of two reciprocal translocations, $T(X ; 7) 5 R I$ and $T(X ; 7) 6 R I$ (abbreviated $R 5$ and $R 6$, respectively), revealed a high frequency of heteromorphic bivalents involving the translocated chromosomes. In both translocations, the breaks are in the proximal third of the 7 and the distal third of the $X$, but the R5 breaks are closer to the 7 centromere and $X$ telomere than the R6 breaks.

In both translocations, the 7 frequently synapsed nonhomologously with the $X 7$. In $R 5$, the part of the $X$ to which the 7 synapsed may 1nclude a region that synapses with the $Y$ in normal mice. However, in $R 6$, the 7 synapsed with a portion of the $X$ that never synapses with the $Y$, synapsis Involving the "differentiated" $X$ region. In both translocations, the $Y$ synapsed maximally with the $X$ portion of the $7^{X}$ in those nuclei in which there was nonhomologous synapsis of the 7 with the $X^{7}$. The $Y$ occas lonally synapsed nonhomologounly with the 7 portion of the $7 \mathrm{X}$. The behavior of the 
bivalents suggests that the autosomal port:ons of the $7^{X}$ and $x^{7}$ may alter the behavior of the sex-chromosome portions.

During pachytene of normal mice, the $X$ and $Y$ chromosomes have a region of synapsis (involving up to $35 \%$ of the distal portion of the $X$ ), as well as unsynapsed, or "differentiated" regions (the proximal two-thirds of the $X$ and the proximal end of the $Y$ ). It has of ten been assumed that $X-Y$ synapsis is homologous, entailing chiasmata that lead to normal $X-Y$ disjunction. Our finding that the $X$ - both in its "differentiated" and in its (normally) Y-pairing portions - is capable of nonhomologous synapsis with an autosome casts doubt on the homology of $X-Y$ synapsis. The early desynapsis of the $X$ and $Y$ in normal wice (and other mamals) way have evolved to decrease the chance of $X-Y$ exchange, which would produce a translocation (rather than crossing over, as would occur with homologous chromosomes). Normal $X-Y$ disjunction may be achieved through an achiasmatic end association.

1. Ashley, T., Nonhomologous synapsis of the ex chromosomes in the heteromorphic bivalents of two $X-7$ translocations in wale mice: R5 and R6. Chromosoma 88: 178-183, 1983.

2. Ashley, T., Russel1, L. B., Cachelro, N. L. A., Synaptonemal complex analysis of $X-7$ translocations in male mice: $I$. R3 and R5 quadrivalents. Chromosoma 87: 149-164, 1982.

3. Ashley, T., Russell, L. B., Cacheiro, N. L. A., Synaptonemal complex analysis of $X-7$ translocations in male mice: $R 2$ and $R 6$ quadrivalent.. Chromosoma 88: 171-177, 1983.

4. Russell, Llane B. X-dutosome translocations in the mouse: their characterization and use as tools to investigate gene inactivation and gene action, in Sandberg, A. $\therefore$. (ed.): The Cytogenetics of the Mammalian X Chromosome, Progress and Topics in Cytogenetics, in press.

INVOLVEMENT OF THE Y CHROMOSOME IN TRANSLOCATIONS

$$
\text { N. L. A. Cachetro }{ }^{3}
$$

Although it is well known that reciprocal translocations involving the $X$ chromosome cause complete sterility in male carriers in the balanced state, effects of translocations involving the $Y$ ciromosome are not well understood. In the course of our studies on sterilit; in male progeny from mutagen treated ingle parents we found 34 translocations involving the $Y$ chromosome, which represents about $30 \%$ of all male-sterile translocations. Each autosome has been Involved at least once, except chromosomes 1 and 11. A mapping of Y-chromosome breakpoints in banded preparations shows the distribution to be wore or less random, with a slight corcentration in the middle of the chromosome. By contrast, in autosome-autosome translocations thst cause sterflity (rather than semi-sterility) at least one of the 
breaks is very close to a chromosomal end. Because all semisterile translocations found so far have been $T(A ; A)$, we can conclude that all $T(Y ; A)$ 's may be sterile.

\title{
MEIOTIC SEGREGATION IN PARTIALLY STERILE MALE TRANSLOCATION HETEROZYGOTES
}

\author{
C. V. Cornett \\ N. L. A. Cacheiro ${ }^{3}$ \\ Shinya Hitotsumachi ${ }^{3}$
}

During several years of studying of radiation- or chemically-induced heritable translocations we have observed that the ratio of partially sterile to sterile male translocation heterozygotes is stage dependent. When spermatogonia were mutagenized, virtually all (221 of 230) translocation carriers were partially sterile, but when postmelotic stages were exposed, about one-third of the translocation carriers (among several hundred analyzed) were fully sterile. Full sterility results from blockage in spermatogenesis. Partially sterile males, on the other hand, produce functional sperm, the subsequent small littersize resulting from early death of embryos that recelved an unbalanced chromosome complement from their fathers. Such unbaianced complements result from adjacent- 1 , adjacent-2, or 3-1 segregations at melosis in translocation-bearing individuals. We have found that, on the average, the proportion of living embryos is only $44 \%$ of normal, the average percentage of chromosomally unbalanced sperm in the ejaculate thus being 56\%. However, different translocation lines are characterized by degrees of partial sterility that are either substantially lower or substantially higt:er than $50 \%$.

Whether, and what type of, multivalent chromosome associations are found in translocation carriers is assumed to depend primarily on the size of translocated chromosome segments, which, in turn, influences the probability of chiasma formation between the translocated segments and their homologous segments in the intact chromosomes. From a study of partiallysterile translocations induced by TEM in male melotic and postmelotic 8tages, Generoso et al. (Mutat. Res, 81: 177-186, 1981) observed a posit1ve correlation between the cegree of partial sterility and the frequency at which multivalent chromosomes were observed in diakinesis-metaphase I spermatocytes. In the present study we are determining whether a similar correlation holds true for translocations derived from exposed spermatogonial stem cells.

Two groups of $X$-ray-1nduced partially-sterile translocations are included in this study: one group (128 animals: derived from treated opermatogonial stemcells, the other (72 animals) from exposed postmelotic stages. All animals came from translocation experiments of W. M. Generoso. Translocation carriers were confirmed by genetic and extensive cytological analyses. As a rule, 25 diakinesis - metaphase I cells are scored from each pair of testes prepared by the alr-drying technique. The index of 
partial sterility is calculated from the average percentage of dead impiantations found at nidpregnancy in 6 females mated to each partially sterile male.

Results for both the gonial and the postmelotic groups again indicate a positive correlation between degree of partial sterility and incidence of multiple chronosome associations. The groups appear to differ in the frequency of confirmed translocation carriers that show no multivalent chromosomes In any of the 25 cells scored per male: there were only $3 \pi(2 / 72)$ of such animals in the group derived from postmelotically-irradiated germ cells, but $137(16 / 128)$ in the group deriyed from irradiated spermatogonial stemcells. This difference is not surprising if, indeed, short translocated segments favor the production of balanced gametes.

A detailed karyotype analysis of translocation stocks that have efther very high or very low degrees of partial sterility is currently underway. This analysis should provide a direct proof for the role of the size of translocated chromosome segments in the melotic segregation of balanced and unbalanced gametes. To date we have lsolated 7 low-degree partially sterile translocation stocks (between $2 \hat{v}$ and $30 \%$ dead implantations) and 7 high-degree partially sterile stocks (between 65 and $80 \%$ dead implantations).

\section{HIGH-RESOLUTION BANDING OF MOUSE PROMETAPHASE-PROPHASE CHROMOSOMES}

$$
\text { N. L. A. Cacheiro }{ }^{3}
$$

Recent technical advances in the' high-resolution banding of human chromosomes from lymphocyte cultures have provided a valuable tool for lacreasing the accuracy in the analysis of breakpoints, and for a better definition of chromosomal rearrangements. We have been successful in obtaining a high-resolution banding pattern in mouse chromosomes from kidney-derived primary tissue cultures, using actinomycin $D$ and a short treatment with colchicine.

The technique has been used by us in confunction with BrdU in the study of inactivation patterns of a number of our X-autosome translocations that, in previous experiments using $3_{H}$ thymidine and regular mitotic chromosome spreads, gave somewhat inconclusive results because of the poor resolution. At present we are also using the technique for the determination and cytological mapping of breakpoints in a number of the $c$-locus deletions in chromosome 7 , and $\underline{d}$ se deletions in chromosome 9.

The examination of late-prophase chromosomes in the study of gene mapping will facilitate the localization of genes producing certain phenotypes to speciflc minute chromosome segments, extending our understanding of the organization and function of the mouse genome. 


\section{MECHANISM OF GENETIC SUPPRESSIGN}

$$
\text { E. H. Grell K. B. Jacobson }
$$

The tern, suppressor, is used to denote a mutation that reverses the effects of a mutation in a gene located elsewhere. The suppressor causes the phenotype of the suppressed mutation to appear completely or partially wild-type. This might be due to a varlety of mechanisms. The type of suppressor that is of most concern to us is the suppressor that partially or completely suppresses several non-allellc mutations. The suppressor locus that we have most intensively examined is su(s). It suppresses vernillion, sable, speck, and purple allelis. It suppresses one or more spontaneous mutations at these loci but it will not suppress mitations induced by $x$-rays or chemical mutagens. On the other hand, mutations of su(s) are easily recovered after treatment with mutagens. The different alleles that are recovered are not equally effective as suppressors. They range from slightly suppressive to very effective suppressors. The relative suppressiveness is consistent. Suppressor alleles that are strong suppressors of one mutation are strong suppressors of other suppressible mutations.

We have concentrated on the suppression of mutations of the pr locus (purple). The $\mathrm{pr}^{+}$allele specifies the structure of a component of sepiapterin synthase. This enzyme can be measured. The enzyme catalyzes a reaction that is in the synthetic pathway of the red pteridine pigments of Drosophila eyes. The effect on eye color 18 an indicator of changes in the enzyme activity. The two suppressible alleles of pr are both spontaneous and ieaky mutations. They are viable as homozygotes. Mutagen-induced mutations of $\mathrm{pr}$ are not leaky, not suppressible, and homozygous lethal. Additionally, variegated position effects affecting the pr locus have been recovered.

The suppression by 8 (s) mutations appears to be associated with a reduction in the amount of $\overline{s u}(8)^{+}$substance. Our hypothesis is that the sus(s) ${ }^{+}$substance is an inhibitor of the mutant sepiapterin synthase. A mutant of su(s) reduces the amount of the inhibitor and therefore such flies have more enzyme activity than those that are su(s) ${ }^{+}$. Extra doses of $\mathrm{su}(s)^{+}$have been added to the genome as small centrf.c fragments at tached to the $X$ chromosome or attached to an autosomal chromosome. The extra doses of $\mathrm{su}(8)^{+}$have the effect of reducing the activity of sepiapterin synthase in pr files. The amount of a heat-labile inhibitor of mutant sepiapterin synthase 18 dependent on the number of doses of ${\mathrm{su}(\mathrm{s})^{+}}^{\text {. }}$

1. Jacobson, K. B., Grell, E. H., Y1m, J. J., Gardner, A. L., Mechanism of suppression In Drosophila melanogaster VIII. Comparison of su(s) alleles for ability to suppress the mutants purple, vermilion and speck. Genet. Res. Camb. 40: 19-32, 1982. 
2. Jacobson, K. B., Yim, J. J., Grell, E. H., Wobbe, C. R., Mechanism of suppression in Drosophila: Evidence for a macromolecule produced by the su(s) ${ }^{+}$locus that inhibits sepiapterin synthase. Cell 30: $817-6 \overline{23,1982 .}$

\title{
CIRCADIAN RHYTHMS OF SPFRMATOGONIAL STEM CELLS
}

\author{
E. F. Oakberg \\ C. Crosthwait Cumings
}

It has repertedly been suggested that spermatogonial stem cells surviving radiation undergo accelerated division in order to replenish the seminiferous epithelium. This more rapid division rate has been invoked to explain the effect of fractionated radiation exposures on chromosome breakage, translocation, and fertility. However, 3H-TdR labeling, followed by acute radiation exposure, suggests that the cell-cycle properties of surviving stem cells are not altered by radiation. Insufficient attention has been given to cell synchronization through selective killing of sensitive cells and/or retardation of other stages of the call cycle. Such an effect would give rise to an oscillating pattern of mitotic activity with time after exposure, with the observed response dependent upon the predorinant cell-cycle stage present at given intervals sampled.

Another possible complication in these studies woula arise if stem cells had a circadian rhythm. Recently, circadian rhythms have been shown to be a significant factor in post-irradiation mitotic activity of the sorneal epithellum (Rubin, Radiat. Res. 89: 65-76, 1982) and bone marrow (Neĉas, Cell Tissue Kinet. 75: 667-672, 1982). These results also suggest that the radiation had no effect on mitotic activity of the stem cells in these tissues. Absence of a circadian rhythm in spermatogonia was reported by Bullough (Proc. Roy. Soc. B, 135: 212-233, 1948), and we later conf 1 rmed his observations, but neither study identifled the stem cell. It was essential to determine if the stem cells have a clrcadian rhythm before meaningful data on the effect of fractionated irradiation on cell-cycle kinetics of stem spermatogonia could be undertaken.

Mice were killed hourly from 8:00 a.m. to 4:00 p.m., and at 6 and 9 p.m., 12 v tnight, and 3 and 6 a.m. Whole mounts of seminiferous tubules were prepared, and mitotic activity of $A_{8}$ spermatogonia determined. The highest mitotic rate, about $2 \%$, was observed at 10 and $11 \mathrm{a} . \mathrm{m} .$, but owing to high varlability among mice, there was no significant difference attributable to time of day.

In order to examine possible differences in DNA synthetic activity with time of day, rice were given a single intraperitoneal infection of $25 \mathrm{HCl} 3 \mathrm{H}-\mathrm{TdR}$, 1rradiated with $300 \mathrm{R} 24 \mathrm{hrs}$ later, and kllled 207 hrs after labeling. This protocol restricts labeling to the long-cycling $A_{g}$ spermatogonia that are presumed to be the true stem cells of the testis. There was a significant effect of time of day, with low values at $9 \mathrm{a} . \mathrm{m}$. and 
12 idnight. This is not a typical circadian rhythn, and the experinent is being repeated in order to deternine if the result was due to sanpling error.

Since different groups of alce given 34 -TdR were exposed to $300 \mathrm{R}$ at 3-hour Intervals throughout the day, a set of slides for scoring cell survival was prepared. There was no effect of time of day on number of sten cells observed 183 hrs after $300 \mathrm{R}$.

Stage of the cycle of the seminiferous epitheliun was a significant variable, with the uttotic index at stage 5 (2.7x) being significantly higher than that at stages 1, 2, 3, 4, and 6. Percentage of labeled cells at stage 1 was significantly lower than that at stages 2-6. Therefore, the connon practice of selecting a single stage of the cycle for study my lead to blased data on response to noxious agents.

1. Oakberg, E. F., Germ cell toxicity: significance in genetic and fertility effects of radiation and chewicals, In Proceedings of the International Workshop on the Principles of Environmental Hutagenesis, Carcinogenesis and Teratogenes1s, May 25-June 1, 1983, Shangha1, The People's Republic of China, Plenua Press, in press.

THE EFPECT OP AGE ON THE SPERMATOGONIAL STEM CELL POPULATION OF THE MDUSE

$$
\text { E. P. Oakberg C. Crosthwait Cumings }
$$

Spermatogonial stem cells can first be Identifled about three days after birth. They have a morphology characteristic of stem cells in the aduli, and have a cell-cycle time much longer than that of differentiating spermatogonia. The division rate of stem cells from 3 to 19 days of age $1 \varepsilon$ more rapid than that in the adult. On the basis of long-term 3H-TdR labeling, cell-cycle properties characteristic of the adult are present at 21 days of age, and do not change thereafter.

Stem-cell numbers, however, decline between 12 weeks and 10 months. The new level 18 then maintalned at 17 and 23 months of age. Some consistent and as yet unexplained changes in the numbers of differentiating spermatngonia ( $A_{1}$ through $B$ ) and preleptotene spermatocytes occur with increasing age. The $A_{1}, A_{2}, A_{3}, A_{4}, I n$, and $B$ spermatogonia do not show the drop in numbers at 10 and 17 months that is shown by the $A_{3}$ (A-stem) spermatogonia, but they do show a decline from 17 to 23 months. At present, cell counts of tubule whole mounts at 12 weeks, 11 months, an : 23 months are being made to check the above data that were based on cel! counts in sections. The whole wounts offer increased precision in the 
Identification of the $A_{8}$, Apr (A-paired), and $A_{a l}$ (A-aligned) spermatogonla, and will ald greatiy in interpreting changes in the stem-cell population with age.

LACK OF EFFECT OF DBCP ON THE MOUSE TESTIS
E. F. Oakberg
C. Crosthwait Cumings

A reduction in spern count in en exposed to DBCP (1,2-dibromo-3chloro propane) has been Indicated in several publications, and testicular atrophy and doninant lethals have been dewonstrated in rats (Whorton and Follart, Mutat. Res. 123: 13-30, 1983). In alce, however, Generoso (personal comminication) observed neither doninant-lethal nor fertility effects after intraperitoneal adninistration of DBCP in corn ofl. The possibilities existed that only a specific stage of spernatogenesis was sensitive, or that a fertility effect nght not be observed in mice owing to the more rapid progress of spermatogenesis than in other species.

To investigate these possibilities, $\left(101 \times \mathrm{C}_{3 \mathrm{H}}\right) \mathrm{F}_{1}$ wice were randomized Int, three groups. Group 1 received no treatment; group 2 recelved an Int-aperitoneal injection of corn ofl, and group 3 recelved $110 \mathrm{mg} / \mathrm{kg}$ of DBCP dissolved in corn ofl. Mice that had recelved corn oll were killed at 5 and 8 days, and those that had recelved DBCP in corn oll were killed 3, 5 , and 8 days after injection. Untreated controls were killed at 3,5 , and 8 days. Iissues were fixed in Zenker-formol, $5 \mu$ paraffin sections were prepared and stained with perlodic-acid-Schiff and hematoxylin, and 100 tubule cross sections per nouse were scored for numbers of spermatogonia and preleptotene spermatocytes.

Statistical analysis reveale. no effect of corn ofl or of DBCP on the spermatogonial and primary-spermatocyte populations. It therefore appears that there may be large species differences in the response to DBCP. Though there could be strain differences as well, on the basis of present data the mouse appears to be a poor model for studying the alleged fertility effects of DBCP in men.

\section{ANALYSIS OF SPONTANEOUS RARLY BMBRYNIC LETHALITY IN MICE}

$$
\text { Martha M. Larsen W. M. Generoso }
$$

In the evaluation of dominant-lethal effects, the most important comparison made between experimental and control groups is based on the incidence of dead implantations, also called deciduomata. However, from the controls of a series of dominant-lethal experiments conducted in our laboratory over many years, it became clear that while the normal incidence 
of deciduonata in uteri of pregnant females does not seem to be affected by the strain of the male parent, it varies considerably with the strain of the female. For example, the normal incidence of deciduomata in pregnant 10- to 12-week-old T-stock females averages about 25\%, but it is oniy about 57 in $(\mathrm{SEC} \times \mathrm{C57BL}) \mathrm{F}_{1}$ or $(\mathrm{C} 3 \mathrm{H} \times \mathrm{C57BL}) \mathrm{F}_{1}$ females of the sane age. It is not known whether the differences in early embryonic mortality are attributable to differences in uterine environment or to properties of the conceptus. The answer to this question has a bearing on the interpretation of dominant-lethal data, and specifically on whether strain differences in the normal incidence of dead implantations reflect differences in the spontaneous frequency of dominant-lethal mutations.

In order to adalyze the factors Influencing the Incldence of spontaneous deciduomata we carried out an embryo transfer expertwent and two shortterm 1n vitro culture studies. The mice used were T-stock and (C3H $x$

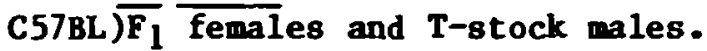

The objective of the enbryi-transfer study was to compare the incidence of deciduomata when normal-appearing 2- to 8-cell embryos are transferred from females of each of the two strains to females of either the same or the other strain. For the two strains of females there are four donor-rectplent combinations. We found a higher incidence of deciduomata (by a factor of about 1.5 - 2) when the donor strain was the $\mathrm{T}$-stock (regardless of the strain of reclplent) than when the donor strain was

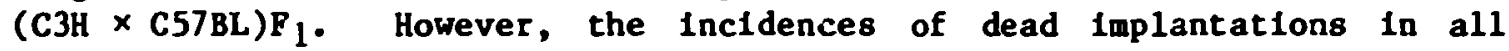
cases were generally higher than expected from natural pregnancies, perhaps due to the stress caused by the transplantation procedure.

Experiments to compare development under culture conditions of embryos from $\mathrm{T}-8$ tock and $(\mathrm{C} 3 \mathrm{H} \times \mathrm{C} 57 \mathrm{BL}) \mathrm{F}_{1}$ females were performed, using embryos collected beginning elther 24 or 48 hours after Insemination of the mother. Two-cell embryos collected beginning 24 hours after insemination of the mother were Incubated for 72 hours. Observations were made at 48 hours and at the end of the culture period. Observation at 48 hours already revealed a difference between the two stocks. Virtually all (97\%) of the embryos from $(\mathrm{C} 3 \mathrm{H} \times \mathrm{C57BL}) \mathrm{F}_{1}$ mothers were at the 8-cell stage, compared to only $34 \%$ of the T-8tock embryos. About $39 \%$ of the latter had remalned at the two-cell stage, and the rest had progressed to the four-cell stage. By 72 hours of Incubation, $84 \%$ of the embryos from (C3H $\times$ C57BL) $F_{1}$ mothers had developed to the blastocyst stage, compared to only $9 \%$ of the T-stock embryos, again showing a marked difference between the two groups of embryos.

In the other in vitro experiment, early development. was studied among embryos collected beginning 48 hours postinsemination and Incubated in culture medium for 48 hours. Virtually all (95\%) of the embryos from $(\mathrm{C} 3 \mathrm{H} \times \mathrm{C57BL}) \mathrm{F}_{1}$ females were at the 8-cell stage at the time of collection. By contrast, about one-third of the T-stock embryos were still at the 4-cell stage at this time. Simllarly, after 24 hours of incubation relatively more embryos from ( $\mathrm{C} 3 \mathrm{H} \times(57 \mathrm{BL}) \mathrm{F}_{1}$ mother 3 had developed to the blastocyst stage. However, after 48 hours of incubation the difference 
between the two stocks in the percentage of enbrycs that had developed to the blastocyst stage had become less pronounced.

The present in vivo and in vitro results both indicate that strain differences in the incidence of spontaneous deciduomata me largely, if not wholly, accounted for by genetic differences between enbryos thenselves in their ability to survive the preinplantation and early inplantation environment. Differences in the uterine environment appear to play a lesser role. A governing factor in early prenatal survival could be the Inherent rate of development during the preimplantation period. If development is relatively slod, as it appears tc be in T-stock enbryos, the conceptus ay be out of synchrony with the short period of uterine receptivity during which successful implantation can take place.

The differences observed between (C3H $\times$ C57BL)F $1 \times T$ and $T \times T$ eabryos in in vitro development fron the 2-cell stage, and in their development in the fallopian tube, are ach larger than the differences between stocks in the incidence of spontaneous deciduonata. Thus, if the rate of development during the preimplantation period is, indeed, a governing factor that determines differences in the incidence of spontaneous deciduonata, it follows that these differences are not attributable to newly occurring dominant-lethal wutations.

1. Generoso, W. M., Cain, Katherine T., Bandy, April J., Some factors affecting the mutagenic response of mouse germ cells to chemicals. In de Serres, F. J., Sheridan, $W_{\text {. }}$ (eds.): Environmental Sc'ence Research, Plenum Press, in press.

ESTABLISHMENT OF AN EMBRYO-FREEZING PROGRAM FOR THE PRESERVATION OF GENETIC STOCKS

Llane B. Russeil Martha M. Larsen

During the past year, the embryo freezing laboratory has been fully operative, equipment and original technique problems having beer solved during the previous year. However, we have only one person working less than full-time on the embryo-freezing project. A computer program for the pertinent data has recently been completed, and information has now been entered for 18 mutant stocks, comprising about 15,000 frozen 8-cell embryos. For each stock, freezing-success trials are performed in which a sample of frozen embryos is thawed, implanted into pseudopregnant host fecales, and ralsed to birth. A stock 18 not discarded unless the trial is successful.

When work with lethal genes was recently inftlated, it became apparent that, In such stocks, progress in collecting the required number of embryos 
for freezing will be slower, since the heterozygous lethal males of ten perfore unsuccessful copulations, so that any mated fenales produce no enbryos at all. In the case of autosonal lethals, oi of sex-11nked Hables, we freeze at least 800 enbryos per stock; in the case of sexlinked lethals, at least 1200; and in the case or autosoar viable genes, at least 400.

We have carried out two comparisons. (1) The suscess rate ( $X$ liveborns) obtained when thawed enbryos are cultured to blastocysts which are then transferred to host females (a technique used at other laboratories) was compared with the success rate fron direct transfer of thawed embryos. The latter was consistently larger, and difect transfer is now being routinely used. (2) The percentage of thawed and cultured eabryos thet form Fable blastocysts (not transferred) was compared to the percentage of thawed and directly transferred embryos that survive to birth. It was hoped that, if a relatively constant ratio could be found for all stocks, the former procedure by itself could be used as a predictor of success. However, the ratios varied rather widely, and we have decided that frequency of liveborns after direct transfer wst be used as our criterion of successful freezing. 


\title{
Toxicology Section
}

\author{
SECTION OVERVIEH - H. R. HITSCHI
}

The main thrust of the work of the Toxicology Section is to understand mechanisus of disease caused by chenical and physical agents. Such a goal can essentially be approached in two ways: by studying the fate of and biological efrects caused by a variety of well-selected chenicals or by trying to delineate and unravel disease processes. By and large, menbers of the Toxicology Section have chosen the second approach: to study the disease rather than individual compounds although chenicals are of ten used as probes.

Constraints in available resources, particularly personnel, made it necessary to limit our efforts. At present, we focus on two organ systems: the skin and the respiratory tract. The two organs play a most important role in defending the body against exogenous chenicals: skin and respiratory tract are the min barriers put up by the living body against most exogenous agents. Acute or chronic diseases of both skin and respiratory tract caused by exogenous agents play an important role in our present society.

Skin disease produced by chenicals is examined at several levels of blological organization. Painting skin of experimental animals with selected agents, mainly products associated with modern coal conversion technologies, informs us about the acute or chronic potential of the agent tested; the acute potential can be assessed by observing the test animal for elther local effects such as skin irritation or skin sensitization, whereas the formation of benign or malignant skin tumors is indicative of tisc effects of chronic, low-level exposure. However, any such effects observed will eventually have to be understood in more mechanistic terms. An important element in our approach to understanding chemically-induced skin disease is experiments in which we explore how chemicals penetrate the Intact skin, how they are transformed by the different cell layers of the skin and how they interact with critical targets within cells of the skin. These studies, carried out with techniques that make use of many advanced methods avallable in cell blology, blochemistry and morphology will provide a solid experimental basis for our understanding of chenlcally-induced skin lesions.

A similar approach is being pursued by several groups that study pathogenes18 and mechanisms oi acute and chronic lung disease. Again emphasis is placed on understanding a biological response to injury rather than merely studying compounds that are known or suspected to produce lung disease. An effort ongoing now for several years deals with induction and 
progression of cancer in the tracheal epitheliun. Methods have now becn developed wich allow us to combine the advantage of experiments with animals with advanced techniques of cell and tissue culture. This will allow us to probe deeper into mechanisus of respiratory carcinogenesis while, at the same tiue, offering a possible and scientifically sound alternative to cumbersome and expensive animal inhalation studies. In addition, progress has been made in studying wechanisus of other forms of chronic lurg disease such as fibrosis and emphysem. A key element appears to be the cellular reactions in the lung and tracheobronchial tree to acute injury, as it begins to become evident that the nature of such acute responses may deteruine to no small extent the development of chronic lesions.

While wost research groups within the Toxicology Section focus thus on skin or respiratory tract, one group concerns itself with fundarental aspects of the inune system and how they ay be compronised by radiation. This work is necessary to better characterize the response of the my components of the immune system to acute injury. Eventually this will help to understand some of the lesfons that develop in efther skin or lung if chenicals do not act directly on these tissues, but wore likely produce damage by interfering with dermal or pulnonary elements of the inmune system.

Finally it should be pointed out that the Toxicology Section is not a closed entity, but that nany groups within the Section collaborate closely with other groups within the Biology Division and with other research divisfons at ORNL. A formal toxicity testing program relles heaviiy on the help and expertise provided by members of the Analytical Chemistry Division for analysis of test agents, monitoring of aerosol generated in inhalation chambers and freparation of radiolabeled compounds, to be used in studies on metabolism anc' disposition of agents. An interdisciplinary group of workers from the Health and Safety Research Division, the Chemistry Division, the Comparative Genetics Section, the Molecular Genetics Section and the Toxicology Section share a common interest in the toxicity and mechanism of action of metals. Workers from the Cancer Section have been called upon to provide help in questions dealing with the metabolism and blotransformation of forelgn compounds or to prepare monoclonal antibodies against proteins that might be released in certain forms of acute or chronic lung infury. Pinally it should be mentioned that several projects, completed or still under way, are carried out in collaboration with workers from universfties, national research institutes or private industry. While such projects may range from providing expertise not avallable to others to getting help not otherwise avallable to us, they nevertheless all have one common these: to further advance our understanding of disease processes brought about by chemicals. 


\section{SYSTEHIC TOXICOLOGY}

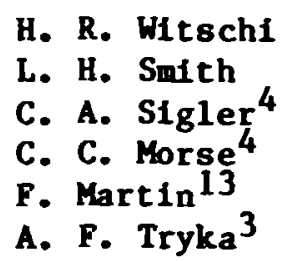

L. Sendelbach ${ }^{1}$

T. J. Stephens

M. J. Whitaker

M. E. Goad ${ }^{3}$

R. C. Lindenschmidt 4

Work done by the Systemic Toxicology Group centered around three themes: (a) elucidation of mechanisms of acute and chronic lung injury, (b) a toxicology testing prograx in which acute and chronic effects of products originating from and associated with synfuel technologies were exanlned, and (c) completion of a 3-year effort concerning the validation of the mouse lung tumor assay as a potential short-term in vivo screening assay for suspected carcinogens. In addition to these ef forts we initiated a series of new experiments on (d) the effects of the antioxidants butylated hydroxytoluene (BHT) and butylated hydroxyanisole (BHA) as modifiers of tumor development in mouse lungs.

(a) Work on potentiation of diffuse alvec ar damage by oxygen continued. The focus shifted towards a detailed analysis of the accompanying changes in pulmonary cell proliferation. Mice were treated with a single intraperitoneal injection of BHT in corn oil or corn ofl alone and immediately exposed to $70 \%$ oxygen or air for 6 days. The animals were infected with $\left({ }^{3} \mathrm{H}\right)$ thymidine 90 minutes before being killed or impianted with thymidine-filled osmotic minipumps. Autoradiography on lung tissue was done 2 to 14 days after injection of BHT and the tissues were analyzed for cell proliferation. We found that exposire to $70 \%$ oxygen immediately after the administration of BHT initially delayed epithelial cell proliferation in lung. Once the animals were removed from oxygen, however, there occurred a compensatory burst of cell division. The proliferating cell population after removing animals from oxygen was primarily interstitial and not epithelial. Th1s explains the ensuing massive fibrotic changes in the lungs of animals so treated (9).

A detalled knowledge of cell kinetics following acute lung injury is thus essential for predicting how lung damage progresses and eventually becomes modified by other agents. This led to a new series of experiments in which we further analyzed the sequence of cell proliferation in lungs damaged by agents other than BHT. As observed following injection of BHT or intravenous injection of olelc acid, we found that with inhaled $\mathrm{CdCl}_{2}$ there 18 an initial burst of epithelial cell proliferation which can be partially blocked by exposure to $80 \%$ oxygen. Not unexpectedly, fibrosis develops. Eptthelial cell proliferation is mach less pronounced fo wing Inhalation of 3-methylfuran than after BHT or $\mathrm{CdCl}_{2}$; the most acti'e cell population is in the small alrways. A different pattern of cell proliferation was obsirved following administracion of the antineoplastic agent cyclophosphamide. In contrast to what had been seen with all other agents, this drug virtually blocked division of pulmonary epithelial cells, and virtually all dividing cells in lung for up to 2 weeks following 
$100 \mathrm{mg} / \mathrm{kg}$ of cyclophosphanide were interstitial cells and capillary endothelial cells. Work along these lines continues and we hope to establish a solid base of information about the different patterns of response to pulmonary injury $(3,6,8)$.

An effort was made to correlate acute lung injury with some measures of pulmonary function. Agents used were BHT, oleic acid, 3-methylfuran or cyclophosphamide. Lung damage was assessed in unanesthetized mice by measuring changes in respiratory rate with a total body plethysmograph. It was found that respiratory rate measured immediately prior to kflling animals correlated well with the degree of pulmonary fibrosis defined as total anount of collagen per lung. However, prior to this timepoint, i.e., when fibrcsis was developing, there was a peak and a trough in respiratory rate response that could not be directly correlated with the development of fibrosis. In an effort to determine the influence of pulmonary edema and lung cell proliferation on respiratory rate, oleic acid was used. 0leic acid produces lung injury followed by a high level of cellular proliferation with only minimal development of fibrosis. Good correlations between respiratory rate and either pulmonary edema or pulmonary cell proliferation were found 3 days after oleic infection. Liver and kidney toxicants and starvation produced either no change or a depression in respiratory rate, making an increase in respiratory rate a rather specific and sensitive index of acute pulmonary injury (2).

Experimental work on the acute and chronic toxicity of 3-methylfuran (3-MF) was completed. In rat, hamster and mouse, 3-MF produced extensive necrosis of bronchiolar epithelium, followed by extensive cell proliferation. Cells in the alveolar zone appeared to be much less damaged than were cells in the small al rways. Many changes were transitory, however, and following a recovery period an essentially normal lung structure was established. One exception appeared to be the epithellum lining the nasal turbinates of rats. Here a single exposure to methylfuran produces extensive necrosis of the epithelial lining, breaks in the basal membrane and eventually development of fibrous tissue coating islands of cartilage which completely filled parts of the lateral nasal turbinates $(7,8,10)$.

Analysis of one life-time study in which animals were exposed to a toxic dose of 3-MP once a week for ten consecutive weeks and then kept for 2 years provided no evidence for a carcinogenic action of 3-MF in mice (1).

(b) Toxicity Testing Program. An integral part of the Biology Division's mission is to provide a data base that will allow us to evaluate the potential health hazards of substances generated by energy technologies. Basic to this evaluation is the determination of acute toxic effects of substances in laboratory animals. For these determinations we routinely use five types of tests to estimate the toxicities of synthetic fuels and of substances related to their production: acute oral and intraperitoneal toxicity in mice $\left(L D_{50}\right)$; acute dermal toxicity in rats; skin and eye irritation in rabbits; and delayed-type allergic hypersensitivity in guinea p1gs. The procedures used for these tests are essentially those employed 
In wany other toxfcology factilties and in general conform to methods set forth in the OECD Guidelines for Testing Chenicals (Paris, 1981).

The substances subattted to us for toxicity testing were obtained from a coal liquefaction facility in which two kinds of coal feed stock were used to generate two groups of analogous samples. Each group consisted of two fuel ofls and three samples collected at different in-line process ports. Oral and intraperitoneal $L_{50}$ determinations of these substances showed that the fuel ofls were moderately tox-: while the three port samples were slightly toxic or nontoxic. After derual application, none of the substances produced skin lesions or systenic effects. One of the fuel oils resulted in moderate-to-severe eye frritation that was reversible. However, none of the other substances produced more than a wild transient skin or eye irritation and none elicited delayed-type hypersensitivity.

When the current results with products from two types of coal were compared with those previously obtained from a third kind of coal (ORNL5685), it appeared that with a minor exception acute toxicity of derived analogs 18 not related to the source of coal used as a feed stock.

The LD50 was determined for two coal liquid blends that had been hydrotreated. The data suggest that reduction in nitrogen content in the liquids may relate directly to oral toxicity.

Seventeen substances associated with the synthetic fossil fuel program are currently under chronic test to determine their tumorigenic potential in mice. The procedures used are essentially those developed in the Blology Division over the last several years. It is anticipated that rne results will provide data on tumor incidence and latency, substance potency relative to benzo(a)pyrene, and systemic effects as revealed by pathologic evaluation.

(c) Mouse Lung Tumor Assay. Assessment of the carcinogenicity of a substance is often made on the basis of data from prolonged or lifetime exposure studies, usually with rodents. Because of the time involved, these studies are expensive, and therefore, efforts have been made to devise other appropriats whole-animal assays that would be 16.so costly and provide answers in a shorter perlod of time. Analysis of the data base strongly suggested that the mouse lung tumor assay developed by Shimkin and co-workers might serve as a rellable routine short-term assay for carcinogens. Therefore, under a contract with NCI-NTP, the Toxicology Group conducted a series of experiments (1980-1982) designed to validate the mouse lung tumor assay in terms of 1 ts use as a routine procedure to 1dentify carcinogens. Validation of the assay was carried out with 30 coded compounds which had been tested previously in a standard 2-year NCI-type carcinogenesis bioassay. Two other groups of substances were also tested - five complex mixtures from modern synfuel processes and eight nitrated toluenes.

Por the assay, male strain A/Jax mice 7 to 9 weeks old were injected intraperitonally with each substance 3 times a week for 8 consecutive 
weeks. After the last injection, the animals were left undisturbed for 4 months and then were killed. The carcinogenicity of each substance was evaluated from the number of mice per group with lung tumors (tumor Incidence) and from the number of visible tumors on the lung surface (tumor multiplicity). Incidence and multiplicity for each treatment group were compared with appropriate vehicle control groups, and statistical significance at the $5 \%$ level was determined by the use of Chi-square for tumor Incidence and Student's t-test for tumor mitiplicity. A detalled report of the project has been published (11).

Among the 30 coded compounds there was one known human carcinogen and 17 for which there was very strong evidence for carcinogenicity in two animal species, strong evidence in one species and sufficient evidence in a second, or strong evidence in one spectes. Of these 18 compounds that we tested in the lung tumor assay, only 5 could be classed as carcinogens. If we add to this observation the fact that two potent animal carcinogens, benzo(a)pyrene and 4-nitroquinoline-1-oxide, were negative in our hands, it can be concluded that the mouse lung tumor assay resulted in a very high percentage of false negatives.

Some of the most definitive data were obtained with the complex mixtures from synfuel processes. Shale ofl and two of 1 ts derivatives and two substances from an experimental coal gasifier were unequivocally positive in the lung tumor assay. None of the efght nitrated toluenes tested were positive.

In vlew of the results with the 30 coded compounds, we conclude that the lung tumor assay is not sufficiently rellable to be used as a routine test for carcinogenicity.

(d) A series of experiments was completed in which a systematic dose-effect and time-effect analysis was done on the enhancement of lung tumors by dietary BHT. The lowest concentration of BHT fed for 8 weeks and capable of promoting lung tumors was found to be $0.1 \%$, and the shortest time of $0.75 \%$ BHT in the diet required to have such an effect was 2 weeks. The cell kinetics accompanying lung tumor development were examined with autoradiography. Urethan by itself 18 able to produce Inhibition of cell proliferation in the first 2 weeks followed later by somewhat enhanced mitotic activity. BHT in the diet produces a substantial burst of cell proliferation within the first 2 to 4 weeks; later the animals become resistant to this ef fect of $B H T$.

While the relationship between tumor promotion and cell proliferation continues to be explored, some potentially important new observations on the modulation of murine lung tumors by dietary antloxidants were made. BHT fed before a carcinogentc dose of urethan has no effect and fed after urethan wlll enhance lung tumor development. Prefeeding of BHA, on the other hand, dit.nishes the response to urethan, whereas postfeeding has no

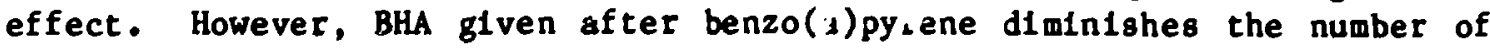
tumors which develop, whereas BHA unde: the same conditions substantially 
Increases the number of tumors found. Additional studies have shown that BHA has no promoting activity.

In conclusion, the common goal of the systemic toxicology group is to study in depth the reaction of one organ, the lung, to various forms of acute and chronic insults and how the biological response of the respiratory apparatus to infury can be modified by extraneous agents (12, $13,15,16)$.

1. Boyd, M. R., Ravindranath, V., Burka, L. T., Dutcher, J. S., Franklin, R. B., Statham, C. N., Haschek, W. M., Hakkinen, P. J., Morse, C. C., Witsch1, H. P., Drug metabolizing enzyme systems and their relationship to toxic mechanisms, In Proceedings of Symposium on New Approaches in Toxiclty Testing and their Application to Human Risk Assessment, St. Louls, M0, Sept. 1983.

2. Hakk1nen, P. J., Frankel, R., Morse, C. C., Witsch1, H. P., Effect of lung, liver and kidney toxicants on respiratory rate in the mouse. Toxdcology 26: 181-192, 1983.

3. Hakkinen, P. J., Haschek, H. M., Comparative pulmonary toxicity of methylcyclopentadienyl manganese tricarbonyl (MMT) in the wouse, rat and hamster. Toxicol. Appl. Pharmacol. 65: 11-22, 1982.

4. Hakkinen, P. J., Morse, C. C., Martin, F. M., Dalbey, W. E., Haschek, W. M., Witschi, H. P., Potent1ating effect of oxygen in lungs damaged by methylcyclopentadienyl manganese tricarbonyl, cadmium chloride, olelc actd, and antitumor drugs. Toxicol. Appl. Pharmacol. 67: 55-6́9, 1983.

5. Hakkinen, P. J., Schmoyer, R. L., Witschi, H. P., Potentiation of butylated hydroxytoluene-induced acute lung damage of oxygen: effects of prednisolone and indomethacin. Amer. Rev. Respir. Dis., in press.

b. Haschek, W. M., Boyd, M. R., Hakkinen, P. J., Owenby, C. S., Witsch1, H. P., Acute Inhalation toxicity of 3-methylfuran in the mouse: pathology, cell kinetics and respiratory rate effect. Toxicol. Appl. Pharmacol., In press.

7. Haschek, W. M., Hakkinen, P. J., Witsch1, H. P., Hanzlik, R. P., Tralger, G. T., Nonclliated ironchiolar eplthelial (Clara) cell necrosis induced by organometallic carbonyl compounds. Toxicol. Lett. 14: 85-92, 1982.

8. Haschek, W. M., Morse, C. C., Boyd, M. R., Hakkinen, P. J., Witsch1, H. P., Pathology of acute inhalation of 3-methylfuran in the rat and hamster. Exp. Mo1. Pathol., In press.

9. Haschek, W. M., Reiser, K. M., Klein-Szanto, A. J. P., Kehrer, J. P., Smith, L. H., Last, J. A., Witschi, H. P., Potentiation of butylated hydroxytolunene-induced acute lung damage by oxygen. Cell kinetics and collagen metabo118m. Am. Rev. Resp1r. D18, 127: 28-34, 1983.

10. Morse, C. C., Boyd, M. R., W1:soht, H. P., The effect of 3-methylfuran inhalation exposure 0 , the rat nasal cavity. Toxicology, in press.

11. Smlth, L. H., Witsch1, H. P., The mouse lung tumor assay: a final report. ORNL $-4961,1983$. 
12. Hitsch1, H. P., Enhancement of tunor formation in wouse lung, in T. J. Slaga (ed.): Tumor Promotion and Carcinogenesis in Internal Organs, Boca Raton, CRC Press, 1983.

13. Witschi, H. P., Doherty, D. G., Butylated hydroxyanisole and lung tumor development in $\mathrm{A} / \mathrm{J}$ mice. Fundam. Appl. Toxicol., submitted.

14. Hitsch1, H. P., Haschek, H. M., Cells of origin of lung tumors in ance. Letters to the Editor, J. Nat1. Cancer Inst. 70: 991, 1983.

15. Witsch1, H. P., Morse, C. C., Enhancement of lung tumor formation in mice by dietary butylated hydroxytoluene: dose-time relationships and cell kinetics. J. Natl. Cancer Inst., In press.

16. Hitschi, H. P., Promotion of lung tumor in mice. Environ. Health Perspect. 50: 267-273, 1983.

INDUCTION AND PROGRESSION OF NEOPLASIA IN TRACHEAL EPITHELIUM
A. C. Marchok
D. H. Martin
L. H. Phipps
H. Hasilenkol

The respiratory tract of man 18 continually accosted by hazardous agents in the environment that are potentially carcinogenic, cocarcinogenic or which way promote the development of lung cancer. Many of these hazardous agents are introduced into the environment as particulates, gases, aercsols, etc. during the refining and utilization of most energy sources. There 18 a great need to develop mammalian model systems that will test for these potentlally hazardous agents under experimental conditions that are well controlled in terms of target site exposed, as well as dose and duration of exposure to the agent. It 18 also important to define and use endpoints that are relevant to the human situation. Therefore, In this program in vivo, in vivo-in vitro and in vitro models have been developed and are utilized to define and quantify cellular and blochemical changes that identify particular stages in the evolution of neoplasia in the epithellum of the rat trachea, a tissue which is simflar to the human bronchus.

In Uyo Exposure to the Test Agent. Several years ago, the rat tracheal 1mplant model was developed in this laboratory to study the Induction and pathogenesis of lung cancer. In th1s model a well-defined target site 18 exrjoed $c=$ test agents released from cylindrical pellets molded to fit th- tracheal lumin. This model has the disadvantages that a pellet can be introduced into a racheal implant only a limited number of times, and re'ease of the agent frow the pellet 18 always initially abrupt and, most 11kely, highly toxic. To itcumvent these problems, an openended, flowthrough tracheal implant 'FTTI) was developed that allows unlimited numbers of exposures to test agents of any physical form, e.g., solutions, gases, particles. The FTTI has the added advantage that the cells which exfoliate into the lumens can be perlodically collected for diagnostic cytopathology. In this way the appearance and progression of lesions in the trachea can be followed, similar to that done with human 
sputum, wthout sacrificing the animals. During the past year studies of the effects of the well known tumor promoter of skin carcinogenesis, tetradecanoyl-phorbol-acetate (TPA) have been initiated using the FTTI. This open-ended tracheal wodel pernits us to use the same experimental regimen commonly done with skin. We have carried out acute dose response studies with TPA. TPA given at $2,6.7$ or $20 \mathrm{Hg}$ twice a week stimulates Increasing levels of basal cell hyperplasia as evidenced by $\left[{ }^{3} \mathrm{H}\right]$-thymidine Incorporation and a marked inflammatory response in the tracheas. A longterm study has been started in which tracheal inplants, fuitiated with dimethylbenzla]anthracene (DMBA), are being exposed $2 \times /$ week to $6.7 \mathrm{Hg}$ TPA. The progression of neoplasia is belng followed by periodic sampling and pathologic diagriosis of the cells exfollating into the tracheal lumen. Pllot studies are also being carried out in collaboration with Dr. Gary Braslawsky to determine whether alterations in the exfoliated cells can also be determined by flow cytometric analysis of different parameters Including DNA content. The promotion of other markers of neoplasia, as described in the next section, is also being followed. The early toxic effects of formaldehyde ( $\mathrm{iCHO}$ ), an ubiquitous environmental pollutant, have also been studied with this model. Exposures for l hr twice a week to HCHO gas mixed with humidifled air at doses of 5,8 or 12 ppm HCHO Induce basal cell hyperplasia and keratinizing squamous wetaplasia within a few weeks. Experiments are being Initiated to study the long-term effects of HCHO given alone and in varlous combinations with benzolalpyrene (Bla $] P)$, a known carcinogen in the environment, to establish whether HCHO is a carcinogen, cocarcinogen or promoter of cancer in the respiratory epithellum. The development of the FTTI model opens up the possibility of testing a wide range of hazardous agents for their toxic and carcinogenic effects on respiratory epithelium in a quantitative fashion not possible before.

In Vivo-In Vitro Model. In vivo models are essentially limited to morphological endpoints. To overcome this limitation a combined in vivoIn vitro model of carcinogenesis was developed which makes it possibie to study a gamut of cellular and blochenical changes in cell populations derived from the tracheal tissue at different times after carcinogen exposure 1n vivo. The approach is to expose tracheal implants to known doses of carcinogen for pre-selected periods of time. The tracheas are then cut Into explants and placed in organ culture for $24 \mathrm{hr}$. A cytopathological diagnosis is then made on the cells that exfollated into the medium, and the explants are placed on the bottom of tissue culture dishes to initiate outgrowth of epithelial cells and establish primary cultures. Carcinogenaltered cells are selected out by placing the 14-day primary cultures in a medium deprived of pyruvate, a component we found to be necessary for the long-term growth of normal tracheal epithelial cells but not altered cells. Further alterations in the selected cell populations are identifled by resting for ability of the cells to survive subculture, acquisition of anchorage-independent growth in agarose and tumorigenicity when inocu? arad back Into a suitable host. We have found dose-dependent effects it.er exposure to dimethylbenz[a]anthracene (DMBA) in terms of the number of explants that yield carcinogen-altered cell populations and decrease in time to anchorage-independent growth as well as to tumorigenicity. Since lesions in the explants are intially identified from the cytopathology of 
exfoliated cells, cellular and biochenical properties of cell populations derived from specific lesions can be studied and correlated directly with conventional morphological markers of the progression of neoplasia. He have found a close correlation between an increase in severity of the lesions and the acquisition of in vitro markers of progression of neoplasia as well as tumorigenicity of the cells when placed back in vivo into sultable hosts. This provides strong evidence that the lesions identified In vivo are indeed the sites of developing cancers. It also indicates to us that we can select specific stages in the progression of neoplasia for further study.

Experiments are in progress to study the effects of TPA on the frequency of induction of preneoplastic cell populations and the progression of neoplasia in these cell populations following initiation with DABA. Similar studies are planned for FTTI exposed to Bla!P and HCHO. Quantifying the number of preneoplastic cell populations following exposure of tracheal implants to a test agent(s) appears to be a highly sensitive and relatively rapid method for determining the carcinogenic potency of the agent in respiratory epithelium. This assay should help to bridge the gap between long-tern whole antmal studies and short-tera manalian cell culture and mutagenesis assays in risk assessment.

We have found that the ability of cells to survive the pyruvate deprived edium is : very early marker of carcinogen-induced alterations. We have put considerable effort toward deterwining the metabolic differences between the pyruvate-requiring normal tracheal epitheilal cells and the carcinogen-altered cells, and have determined the following: (1) Pyruvate does not act on normal cells by directly stimulating cell proliferation. When pyruyate is removed from the medium, the normal cells continue to incorporate $\left[{ }^{3} \mathrm{H}\right]$-thymidine into DNA at the same rate. However, cells increasingly teruinally differentiate toward keratinization and are lost. (2) Normal tracheal cells take up at least 5 t1mes more $\left[{ }^{14} \mathrm{C}\right.$ ] pyruvate than carcinogen-altered cells in most of the cell fractions. (3) There are no differences in the utilization of $\left[{ }^{14} \mathrm{C}\right]$ glucose or $\left[{ }^{14} \mathrm{C}\right]$ glutamine between the two cell populations. (4) Carcinogen-altered cells utflize more $\left[{ }^{14} \mathrm{C}\right]$-alanine than normal cells. These findings point out the marked changes in metabolism that occur early in carcinogen-altered cells. Experiments will be continued to further elucidate these metabolic differences and how they relate to the changes in growth control in these cells. (5) Increase in uptake of $\left[{ }^{14} \mathrm{c}\right]-2$-deoxyglucose 18 not an early marker of neoplasia, nor 18 it a definitive marker of tumorigenicity in tracheal eplthelial cells as claimed for some cell types. [ ${ }^{4} \mathrm{C} /$-2-deoxyglucose uptake is actually lower in preneoplstic cells as compared to normal cells. This uptake remains low in some tumor cells, but markedly increases in others. The latter are from rapidly growing, undifferentiated carcinomas. (6) A good in vitro marker for tumorigenicity is the ability of the tracheal cells to form multinuclel in vitro in the presence of cytochalasin B. 
1. Klein-Szanto, A. J. P., Pal, B. C., Terzaghi, M., Marchok, A. C., Heterotopic tracheal transplants: techniques and applications, in Hook, G. E. R., (ed.): Pulmonary Toxicology, New York, Raven Press, In press.

2. Marchok, A. C., In vitro models for the study of carcinogens in rat tracheal epithelfur, In Webber, M., Sekeley, I. (eds.): In vitro Hodels for Cancer Research, CRC Press, In press.

3. Marchok, A., Nettesheln, P., Johnston, W. H., Locallzat ion of specific lesions in dinethylbenz(a)anthracene-preexposed tracheal explants. Ali. J. Paihol. 109: 321-329, 1982.

4. Netteshein, P., Marchok, A., Neoplastic development in airway epithelfua. Adv. Cancer Res. 39: 1-70, 1983.

5. Shiba, M., Rlein-Szanto, A. J. P., Marchok, A. C., Pal, B. C., Netteshein, P., Effects of carcinogen-release rate on the incidence of preneoplastic and neoplastic lesions of the respiratory tract epitheIfum in rats. J. Natl. Cancer Inst. 69: 1155-1162, 1982.

6. Shiba, M., Marchok, A. C., Klein-Szanto, A. J. P., An open-ended rat tracheal Implant wodel: Toxic effects of formaldehyde on respiratory epitheliun. Toxicol. Lett. 16: 241-248, 1983.

7. Shiba, M., Marchok, A. C., Kleln-Szanto, A. J. P., The effects of formaldehyde in a flow-through rat tracheal inplant system. Toxicology, in press.

\section{INHALATION TOXICOLOGY}

\section{Simon Lock Fred J. Stenglein, Jr.}

The Inhalation toxicology group has been active in two main areas of research: (a) exposure of rats to diesel fuel aerosol, and (b) exposure of mice to ethylene oxide.

(a) The work with the diesel fuel aerosol was part of an ongoing program supported by the Smokes and Obscurants program within the Health Effects Research Division of the United States Army Medical Bioengineering Research and Development Laboratory. Briefly diesel fuel aerosol is used as a smoke screen by the U.S. Army. In the laboratory h - have produced a very similar aerosol to that used by the military by flash vaporization of diesel fuel in a $100 \%$ nitrogen atwosphere and subsequent recondensation in the chamber alr stream. The first two phases of this work were undertaken to look at the acute effects following single exposure and to study the relative Importance of concentration, duration of exposure and frequency of exposure when animals were exposed a total of nine times. The matrix design used included a range of concentrations from 0 to $6 \mathrm{mg} / \mathrm{L}$, exposure durations of 2 or 6 hours and frequencies of once/week for ? weeks or three times/week for 3 weeks. Both the single and repeat exposure studies were 
used to define what parameters to measure and what exposure concentrations would be suitable for tire final phase of this work: a subchronic study.

In the sub-chronic study male and female rats were exposed twice/week for 4 hours/day to concentrations ranging from 0 to $1.5 \mathrm{mg} / \mathrm{L}$. Body weight was followed on a weekly basis over the 13-week exposure period and in those animals not sacrificed at the end of exposure body weight was followed for a further 8-week recovery period. Food consumption was also measured on a weekly basis and followed throughout the exposure and recovery periods in a sub-group of animals. Animals that were not scheduled for sacrifice until after the two month recovery period were also used to test for changes in startle reflex as a result of multiple exposure. Each animal used for this assay was tested for its reaction to an auditory stimulus $(110 \mathrm{~dB}, 13 \mathrm{KHz}$ for $10 \mathrm{msec}$ ) prior to the start of the exposures in order to obtatn a baseline resyonse for that aninal. One day before the 14th and 26th exposures and at 1 and 2 months af ter treatment had ceased both male and female animals were tested to determine whether there was a performance decrement as a result of frequent exposure and if so whether there was evidence of recovery. Male animals were also tested imediately after the first, fourteenth and $26 \mathrm{th}$ exposures to see whether the low diesel fuel aerosol concentrations had acute effects similar to those observed previously at higher aerosol concentrations (i.e., greater number of non-responses, longer reaction time and reduced force exerted on the strain gauge). At the end of the exposures or after two months recovery animals were examined in a battery of pulmonary function tests, or alveolar free cell populations were studied. Blood samples were sent to the Medical Department for serum chemistry anaiyses and those animals used In the pulmonary function tests were subsequently necropsied.

The overall conclusion derived from these experiments was that low concentrations of diesel fuel aerosol had winimal effects on any of the parameters measured. However, there were some concentration related trends including slower growth with increasing aerosol concentration and changes in certain lung volumes immediately postexposure. The effects on the different lung volumes included a slight depression in total lung capacity as concentration increased and simflar changes in vital capacity and inspiratory capacity. The trends were more evident in females than in males and immediately after exposure rather than after 2 months recovery.

(b) One branch of EPA has been mandated to study the mutagenic potertial of industrial chemicals. A compound of particular interest to them because of 1 ts extremely extensive useage ${ }^{2} 8$ an intermediate in a diversity of manufacturing processes is ethylene oxide (EtO). The current threshold limit value (TLV) for erhylene oxide has been set by OSHA at $50 \mathrm{ppm}$, but because of health prollems associated with exposure to EtO, there are movements to lower the TIV to $1 \mathrm{ppm}$ with a $5 \mathrm{ppm}$ ceiling. One interest of the EPA is whether EtO can cause mutations or other toxic effects on the hematopoletic system.

A collaborative Investigation of this matter was carrled out in the Blology Division by the inialation toxicology group, Dr. Raymond Popp's 
group who studied the hesatopoietic toxicology, Dr. Gene Perkin's group who studied Imonocompetence following exposure and Dr. Jullan Preston's group who looked at aberrations in sister chroeatid exchange. Following wodifications to an exposure chamber and the design of a continuous remote montoring systen based on a Miran IA (Infrared spectrometer), a subchronic study was carried out. Male C57BL/6 mice were exposed to $255 \mathrm{PP}$ ( $\pm 10 \mathrm{pps}$ ), 6 hours/day, 5 days/week for up to 10 meeks. The sxposure concentration of 255 ppn was selected by the EPA based on the assumption that If all the Inhaled ethylene oxide was absorbed by the animal then 255 ppa over 10 weeks would be approxinately equivalent to exposing a man for one year to the current TLV ( $58 \mathrm{ppa})$. While the concentration-time (Ct) product does not necessarily hold true it is a good starting point for this type of experimental protocol. A parallel study was also carried out in which antmals were exposed 6 hours/day for 1 to 14 days straight.

There were a few (4 aninals) early wrtalities in exposure groups. However, since they all occurred in one cage it is believed that infection alght have been the prinary cause of death, exacerbated by the stress of exposure. While no significant witagenic effects were observed there were some inportant changes in various cell populations. These changes included loss of granulocytic elements in bone marrow at early tive points followed by replacement and hyperproliferation, and a significant defression in lymphocytes in the peripheral blood.

It would appear that the inmunocompetence of the mice is severely depressed during the first few days of exposure; however, there dces seem to be a correction in this depression as the animals receive more exposures. Further studies are planned to look at the alteration in the immunological function as a result of exposure to EtO. Research will be directed toward the early time points and the effect of concentration on Immunocompetence.

1. Dajbey, W. E., Lock, S., Inhalation toxicology of diesel fuel obscurant aerosol in Sprague-Dawley rats. Pinal Report, Phase 1, Acute Exposures, ORNL/TM-8867, 1983.

2. Dalbey, W. E., Lock, S., Inhalation toxicology of diesel fuel obscurant aerosol In Sprague-Dawley rats. Pinal Report, Phase 2, Repeated Exposures, submitted.

3. Dalbey, W., Lock, S., Moneyhun, J., Holmberg, R., Guerin, M., Inhalation exposures of rats to aerosolized diesel fuel, in Macfarland, H. E., Holdsworth, J. A., MacGregor, J. A., Call, R. W., Kane, M. L., (eds): Proceedings of the Symposium on the ioxicology of Petroleum Hydrocarbons, Washington, D.C., API, 1982, pp. 13-25.

4. Lock, S., Lavigne, J., Plaa, G. L., The effec. of a-napthylisothiocyanate on bile secretion prior to and during the onset of cholestasis in the rat. Toxicol. Lett. 18: 427-435, 1982.

5. Lock, S., Witsch1, H. P., Plaa, G. L., The effect of ethanoi on the uptake of xenobfotics by the lsolated perfused rabtit lung. Toxicology 26: 125-133, 1983. 
6. Plaa, G. L., Hewitt, W. R., du Soulch, P.: Callle, G., Lock, S., Isopropanol and acetone potentiation of carbon tetrachloride-induced hepatotoxfcity: single versus repetitive pretrutwent in rats. J. Toxicol. Environ. Hezlth 9: 235-250, 1982.

\title{
IN VITRO STUDIES OF CUTANEOUS TOXICITY AND CHEMICAL-SKIN INTERACTIONS
}

\author{
J. Y. Kao \\ M. J. Whitaker \\ J. H. Hall
}

The alms and objectives of this research program are (a) to develop mechanistic and functional approaches for use in studying problems in deratotoxicology, (b) to develop a better understanding of the factors Involved in the Interaction of chentcals with the skin and subsequent toxic responses, e.g., toxicokinetics of percutaneous absorption, cutaneous metabolisi and disposition of topically applied chenicals, and biochenical and histological changes in the skin resulting from interaction with xenoblotics, (c) to identify possible biochenical and functional parameters for toxicity quantitation, and (d) to develop a quantitative basis tor extrapolation from animal to man. Our experimental approach is to make use of in vitro methods utilizing mamalian skin in organ culture.

In order to better establish a quantitative basis for the extrapolation of cutaneous toxicity observations from animals to man, we have developed in vitro systems to study the toxicity, translocation and coupled biotransformation of topically applied materials in mammalian skin.

Two systems for maintaining metabolically viable and structurally Intact mouse skin as short term organ cultures (24-48 hcurs) are being used. An important property of our culture systems is that chemicals of Interest can be applied to the skin surface in a manner similar to exposure In vivo and the material of interest reaches the epidermal cells by diffusion thrnugh the various strata of the skin.

In the "static" system disks of freshly excised skin, 1 " in diameter, are maintained in a controlled optimal environment, supported on filter paper in individual organ culture dishes containing suitable culture medium (2). In the "dynamic" system, on the other hand, the skin disks form the upper seal of $1 \mathrm{ml}$ wells of a compact, water facketed multisample skin penetration chamber ( 1 ). Fresh, oxygenated culture medium is continuously passed through the wells and the well effluents are collected via a fraction collector. Metabollc viability and structural integrity of the cultured skin 18 evaluated based on histological examination, in vitro Incorporation of radiolabeled precursors into cellular macromolecules (2) and the ability of the culture tissue to metabolize ${ }^{14} \mathrm{C}-$ glucnse (3).

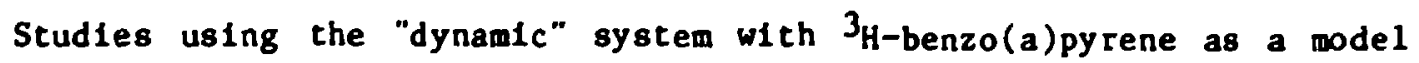
aromatic hydrocarbon have shown that, at the low doses investigated, the 
rate of translocation of benzo(a)pyrene across the intact, full thickness mouse skin was related to its metabolic viability; and translocation of benzo(a)pyreze in mose skin was dose dependent and linear up to $5 \mathrm{~kg}$ per skin disk $\left(200 a^{2}\right)$. Following in vivo topical or systenic induction with TCDD, a two-threefold increase in the overall penetration of benzo(a)pyrene was observed (1). Sex and strain differences were also apparent.

Preliminary analysis denonstrated the presence of essentially only polar metabolites of benzo(a)pyrene in the effluent medium from the penetration chamber. Subsequent studies wital ${ }^{14} \mathrm{C}$-benzo(a)pyrene using the "static" systen demonstrated siailar overall penetration of in vitro topically applied benzo(a)pyrene. The majority of the radioactivity in the culture media was not extractable into ethylacetate. Chromatography of the organic fractions showed that all classes of benzo(a)pyrene metabolites were present. Dihydrodiols and "polar netabolites" predoninated and negligible anounts of unmetabolized benzo(a)pyrene were found. Enzymic hydrolysis of the media showed that TCDD induction shifts the metabolism towards more water soluble conjugates. Differences in the degree of In vitro covalent binding of benzo(a)pyrene, via the diol epoxide 1iteraediates, to epidermal DNA from control and induced tissues were observed. These differences may also reflect the change in the pathways of atabolism of benzo(a)pyrene as a consequence of TCDD induction (3).

It is important to note that these in vitro toxicokinetic studies can be performed under conditions where the influence of local cutaneous toxicity of the topically applied chemical can be monitored. It has been demonstrated that mouse skin maintained in our culture system responds to toxic insults with blochemical changes. These changes, which included leakage of intracellular enzymes out of damaged cells and reduced incorporation of radiolabeled precursor into tissue racromolecules, are sensitive indicators of cellular injurles; as such the" may offer a simpie measure for assessing cutaneous toxicity of chemicals in vitro (2). Since local cutaneous toxicity may have profound effects on the fuactional capabilities of the skin, an assessment of toxicity may be an important factor in skin penetration studies. Kecent studies in our laboratory have demonstrated that following in vivo exposure to topical tributyltin chloride, 3 known skin 1rritant (Barnes, J. N., Brit. J. Industr. Med. 15: 15-22, 1958; Lyle, W. H., Br1t. J. Industr. Med. 15: 193-196, 1958), the in vitro penetration of benzo(a)pyrene in mouse skin was significantly Impalred (Kao, unpublished observations).

These studles with wouse skin dewonstrated that percutaneous translocation of surface applipd benzo(a)pyrene is coupled to cutaneous metabolism. In acdition, it is dependent upon the metabolic status and blochemical viability if the skin. However, current studles with rabbit and guinea pig skin have indicated that not only is the overall skin penetration of benzo(a)pyrene in these species much lower than in the mouse, but also there are no differences in the translocation of benzo(a)pyrene between viable and nonviable tissues. In contrast, studies with testosterone have shown that penetration of this sterold through metabol1cally viable skin from all three specles was significantly lower than 
through the corresponding nonviable tissue (Kao, unpublished observations). Skin permeabjilty is a complex phenowenon influenced by a variety of blological and phystochenical factors. For a great any compounds the stratun corneun appears to be the barrier of primary inportance. For lipophilic chenicals, such as aromatic hydrocarbons and steroids, it is iess clear that the stratur corneun is a barrier at all. The lipid rich stratun corneun and skin appendages such as the philosebaceous apparatus way act as a "sink" for topically applled lipotropic aterial (Holland, J. M., et al., An. Ind. Hyg. Assoc. J. 40: 496-503, 1979). Rather than a barrier, the stratum corneun may function wre as a sponge, capable of absorbing a quantity of lipoph.11c material linted only by the solubility of the substances in sebaceous and intrinsic lipids.

Wuch of the evaluation of in vitro penetration has been conducted using frozen or nonviable skin that is incapable of respiration. However, the recovery of merial diffusing through dead skin may not be a useful neasure of percutaneous penetration. Our studies suggest that percutaneous absorption may involve both diffusional and netabolic processes. The relative importance of these processes in skin penetration of chenicals w11 depend on the physlochemical properties of the compound and the metabolic capabilities of the epideral cells toward the compound in question. The use of nonviable skin ay provide infornation on the diffusional aspect of penetration, while the net results of the diffusional and metabolic components may be obtained by the use of metabolically viable and structurally intact skin. It should be noted, however, that a special problew associated with is vitro skin penetration studies of water Insoluble compounds involves the inability of the chenical to partition Into the aqueous receptor fluid. The role of a metabolically active viable eplderwis is to convert a water insoluble compound to a water soluble wetabolite capable of partitioning into the receptor fluid. This problem is currently being addressed in our laboratory.

Taken together, our studies strongly implicated cutaneous wetabolism to be an important determinant in the percutaneous absorption of certain 11pophilic chemicals. They also indicated that meaningful in vitro neasures of jkin penetration should take into consideration both the viablity and metabollc status of the skin penetration.

1. Holland, J. M., Kao, J., Whitaker, M. J., A multisample apparatus for kinetic evaluation of skin penetration in vitro: The influence of viablify and metabolic status of the skin. Toxicol. Appl. Pharmacol., In pres8.

2. Kao, J., Hall, J., Holland, J. M., Quantitation of cutaneous toxicfty: An in vitro approach using skin organ culture. Toxicol. Appl. Pharmacol. 68: 206-217, 1983.

3. Kao, J., Hal1, J., Shugart, L. R., Holland, J. M., An in vitro approach to studying citaneous metabolism and disposition of topically applied xenoblotics. Toxicol. Anp1. Pharmacol., subuitted. 


\title{
DOSIMETRY OF PAH IN SKIN CARCINOGENESIS
}

\author{
L. R. Shugart \\ B. H. Chastain \\ J. M. Holland \\ J. Y. Kao
}

Developmenc of a synthetic petroleuk industry raises concerns about potential exposures of workers and the general population to complex organic nixtures. Because one of the most probable routes of exposure is through the skin, we are interested in devising methods of cutaneous exposure to these materials that can be used in quantifying the overall extent of protocarcinogenic tissue insult. From such information we expect to obtain estinates of human cutaneous exposure risk.

We have dewonstrated that wouse skin in organ culture is an Ideal bioassay systen because it possesses the pharmacokinetic and pharmacodynamic properties that are present in the 1 .cact whole animal (1). Currently we are evaluat ing this technique for screening potential chemical carcinogens. In particular we are focusing on the classical PAH compound benzo[a]pyrene (BaP) (4).

Since the metabolism of any carcinogen by mouse skin can be influenced by the interferences and/or interactions of all compounds present, our approach has been to attempt to measure the covalent interaction of the chemical in question with cellular DNA. The rationale for this approach is based on the hypothesis that this represents the critical step in chemical carcinogenes is (Harvey, R., Am. Sc1. 70: 386-393, 1982). For example, subsequent to toplcal application of BaP to mouse sk1n, metabolic activation occurs stereospecifically to the chemically reactive diol epoxides (DE), which can then bind covalently to cellular macromolecules. The primary adduct formed via BaPDE with DNA is ant1-BaPDE/deoxyriboguanosine, and there is good correlation between the amount of BaPDE bound to DNA of mouse skin and the carcinogenic activity of BaP. We have demonstrated that tetrols liberated from BaPDE/DNA adducts by acid hydrolysis are easily quantified by HPLC and fluorescence detection $(2,3)$, which allows femtomole amounts of BaPDE associated with the DNA lsolated from a single mouse to be detected using coventional instrumentation (4).

Recently we were able to use the mouse skin in organ culture system to demonstrate its sultability for testing the effect of ellagic acid on aeduct formation (5). Recent studies had shown that ellagic acid, a product of the degradation of certain plant tannins, inhibited the mutagenicity of ant1-BaPDE in Salmonella typhimurlum as well as the mutagenic and cytotoxic effects of the compound in Chinese hamster 79 cells, without any detectable harmful activity by itself (Wood, A. W., et al., Proc. Nat1. Acad. Sc1. USA, 79: 5513-5517, 1982). Since li:e Inhibitory effect of ellagic acid had been postulated to be due to its direct and faclle interaction with ant1-BaPDE to form an inactivated adduct we sought to determine whether or not in our system subsequent covalent binding of ant1-BaPDE to DNA also occurred. We found that ellagic acid did not interfere with the metabolism of BaP but did affect the binding of ant1-BaPDE to cellular DNA (5). 
Other fa:-irs orst be considered in attempting to relate the amount of adducts formed with BaPDE carcinogenicity, and we are proceeding to aiswer the question of the significance of the persistence of adducts once formed, and the importance of finctional toxicity resulting from the carcinogen, the vehicle or the metabolic products accumulating in the target cells.

1. Kao, J., Hall, J., Holland, J. M., Quantitation of cutaneous toxicity: An in vitro approach using skin organ culture. Toxicol. Appl. Pharmacol. 68: 206-217, 1983.

2. Rahn, R. 0., Chang, S. S., Holland, J. M., Shugart, L., A fluorometric-HPLC assay for quantitating the binding of BaP metabolites to DXA. Biochen. Biophys. Res. Commun. 109: 262-268, 1982.

3. Shugart, L., Rahn, R. 0., Holland, J. M., Quantifying berizo[a]pyrene binding to DNA by fluorescent analysis. PAH's: 7th Int 1. Symposium, Columbus, Ohio, Battelle Press, 1982, pp. 1087-1097.

4. Shugart, L., Holland, J. M., Rahn, R. 0., Dosimetry of PAH skin carctnogenesis: Covalent binding of BaP to mouse epidermal DNA. Carcinogenes1s 4: 195-198, 1983.

5. Shugart, L., Kao, J., Effect of ellagic and caffelc acids on covalent binding of benzola]pyrene to epidermal DNA of mouse skin in organ culture, in press.

\section{RADIATION IMMUNOLOGY}

$$
\text { E. H. Perkins W. C. K11ma }
$$

The purpose of this research is to define the role of the lmmune system and Immunologic dysfunction in radiation carcinogenesis, 1.e., (1) the role of acute tmmunodepression in the induction of leukemia and late arising tumors, (2) the significance of autogenous immunity, (3) the possible restriction of tumor induction by immunoregulation, (4) the enhancement of the Immunogenicity of leukemic cells and solid tumors by In vitro cultivation and selective cloning, and (5) correlation of immunocompetence and target cell susceptibility. Current studies center on two models of leukemogenesis to evaluate both immunologic and nonimmunologic mechanisms in the shifts of leukemla incidence. In nonirradiated RFM mice four primary types of leukemia occur (reticulum cell sarcoma, myelold leukemia, thymic lymphoma and nonthymic lymphoma) almost exclusively in the last third of life, retlculum cell sarcoma accounting for $90 \%$ of the total. After Irradiation thymlc lymphoma reaches $>60 \%$ with an induction period of 5-6 months. Myelold leukemla also increases but the time of occurrence 18 only slightly advanced. Two studies to shift and increase the incidence of myelold leukemla are in progress. Both attempt. to reduce early thymic lymphoma 80 more animals are at rlsk for the induction of myelold leukemia. Young-adult animals were thymectomized and then 1rradiated, or mice were irradiated at $81 x$ months of age (at an age when the induction of thymic 
lynphoma is sharply decreased). Replicate groups of both male and female mice have been included because radiation-induced thymic lymphonas are significantly higher in RFM females than in males, whereas velold leukemia is more common in males. Immune parameters are monitored because imme competence is significantly reduced in thymectomized mice an iso declines with age. An incidence ( $>50 \%$ ) of myeloid leukemia is desirable for conducting immunological reconstitutive and immunoregulatory studies.

Concurrently we are investigating the effects of spleen and bone marrow reconstitution on myeloid leukemia in RPM mice. It is important to determine if immunohematopoletic reconstitution after irradiation will significantly alter the incidence of radiation induced wyeloit leukemia. If Immediate Imonological restoration is of significance in interrupting the Inductive process, spleen cells should prove more effective than bone marrow cells. With thymic lywphomas restoration of immunocompetence was more rapid among spleen-cell reconstituted animals, but spleen sells failied to protect against the irradiation-induced thymic lymphoma. In contrast, ibmunologic recovery of bone marrow-reconstituted animals was not enhanced but mortality from thymic lymphomas was both delayed and reduced as a result of marrow injection. The present investigation permits us to compare the effects of immunologic and immunologic and cellular restoration on radiation disruption of cellular homeostasis in myelold leukemia with the cellular perturbation observed in thymic lymphomas and to evaluate the significance of Immunological dysfunction in the induction of two leukemias where different susceptible target cells are Implicated.

Cell transfer experiments demonstrace a high incidence of potential lymphoma (preleukemic) cells in the bone marrow of Irradiated older ( 8 months) mice; however, these mice never develop overt leukemia. These observations have allowed us to further investigate the significance of the Immune system in the age-related resistance to thymic lymphoma. 01d mice were grafted with a nennatal thymus under the kidney capsule. Thirty days later, when the thymus graft had grown and differentiated into a fully functional organ, mice were exposed to irradiation and observed for the development of both thymic lymphoma and myelold leukemia. Some animals die of massive lymphomas, as early as 90 days after frradiation. Hence, when a target organ with a sultable microenvironment is restored, susceptibility to thymic lymphomas occurs. Measured immune competence is significantly less in these older animals but to relate the apparent increased susceptibility to decreased immune competence is premature. In another experiment assessing the effects of humoral factors in the induction of thymic lymphoma, injection of serum obtained from old RPM mice (which are refractory to induction of thymic lymphoma) reduced the incidence and delayed the onset of thymlc lymphoma among these normally highly susceftible young adult animals. Th1s finding implicates the humoral immur.e system and autogenous immunity perhaps to the murine leukemia virus. Th? experiment has not progressed sufficlently to assess the effect on myeloid leukemia. In th1s context, considering myelold leukemia, 1088 of a susceptible target population is probably not a causal factor, and autogenous 1mmunity may not. have a dramatic effect if age-dependent immune competence is of importance. 
It has commonly been accepted that malignant cells may in some situations be killed by the body's defense systems. Specific immunization generally augments these defense mechanisms, provided sufficient immunogenicity is present in the tumor cell innoculum. Immunization was at tempted by intravenous injection of $2 \times 10^{7}$ X-irradiated spleen cells of an in vivo passaged myeloid leukemia line (harvested when the spleen was twice its normal size). Mice were injected thrice at 3-week intervals and challenged 4-6 weeks later. Mortality for the "1mmunized" and control mice did not differ. In other studies using a diethylnitrosamine-induced squamous cell forestomach carcinoma, we observed that a tumor line is heterogeneous in cellular akeup and consists of cells with different immunogenic properties. Furthermore, studies using different in vitro propagated clones isolated from the same tumor cell line showed that some highly immunogenic cells are masked or are too infrequent to be demonstrable in the primary tumor cell population but can be selectively cloned out. Cloning experiments will be carried out to provide more conclusive evidence for the presence or absence of demonstrable tumor immunogenicity for bot's myeloid leukemia and thymic lymphoma.

We have aiso examined what effect an endogeneous entrophic virus (RFM V-1) induced and isolated in vitro from embryonic RFM cells might have on the induction of myelold leukemia. In non-irradiated RPM mice, the virus does not produce leukemia. Mice received 300R X-irradiation and half the animals were injected intraperitoneally with $4.7 \times 10^{5}$ plaque forming units of the virus. Mortality curves to date from the virus infected and noninfected animals appear to be quite comparable. While most animals have died of thymic lymphoma, the relative incidence of thymic and myeloid leukemia (as judged from gross pathology) between the two groups may be different. Conclusions mist be deferred until all animals are dead (the remaining $30 \%$ are expected to die primarily from myeloid leukemia) and until microscopic examination can confirm types and incidences of leukemia.

1. Holland, J. M., Perkins, E. H., Resistance of germ-free athymic nude mice to two-stage carcinogenesis, in Reed, N. D. (ed.): Proceedings of the Third International Workshop on Nude Mice, Vol. 2, Gustav Fischer New York Inc., 1982, pp. 423-433.

2. Holmes, K. L., Schnizlein, C. T., Perkins, E. H., Tew, J. G., The effect of age on antigen retention in lymphoid follicles and in collagenous tissue of mice, Mech. Ageing Dev., accepted.

3. Jamasbi, R. J., Perkins, E. H., The generation of 1mmunoprotection agalnst squamous cell carcinomas by in vitro cultivation. Cancer, Immunol. Immunother., accepted.

4. Perkins, E. H., Glover, P. L., The prollferative capacitles of popliteal lymph node lymphocytes and their functlonally distirct $T$ cell subpopulations from young adult and old mice. Mech. Ageing Dev. 21: 168-182, 1983. 


\title{
Cancer Section
}

\author{
SECTION OVERVIEW - R. J. M. FRY
}

The genetic nature of cancer has long been known and the molecular intricacies of this association are becouing clearer from the results of the extensive and exc1ting work on oncogenes and the control of their transcription. Molecular changes do not alone make a cancer because cellular, tissue and systemic factors play a major role in whether or not and when an overt cancer occurs. Chemical carcinogens, radiation and viruses interact with cells in very different ways but at some stage of the cascade of events there must be a common pathway that leads to neoplasia. To understand such a complex process it is necessary to study many facets of the blology of cells, tissues and whole animals.

Although the number of members of this section is much smaller than in former years the spectrum of studies remains broad. The ability to maintain the breadtr. of the program stems in part from collaboration both within the division and with colleagues in other institutes.

The study of radiation-induced leukemia has required some very basic studies of the various elements that are involver in the susceptibility to leukemia and the process of 1ts development. For example, the Molecular Genetics Carcinogenesis group has cloned the genome of the ecotropic retrovirus found on chromosome 5 in KFM/Un embryonic cells and its characteristics have been dissected by restriction endonuclease mapping. There is reason to belleve that this viral genome is associated with the genesis of myeloid leukemla that 18 found to occur naturally and that can be induced in RFM mice. The nucleotide sequence of the long terminal repeats (LTR) of the iral gene has now been determined.

The search continues for unequivocal evidence of the role of movable gene elements in the transformation process that may follow the interaction of a carcinogenic agent and the genome of a cell. There are genes that have certain sequence characteristics found in retroviral genes but that occur in numbers that cannot be accounted for on the basis of expression of the viral genes. The multiplicity of these genes may be due to the transposability of these genes and certain characteristi:s of the control mechinisms that govern 1ntegration. These elements must be considered as the possible targets affected by various agents including carcinogens.

An important aspect of understanding the mechanisms of the action of viruses 18 concerned with Fv-1 gene restriction and how Fv-l gene products result in the inhibition of replication of the retroviruses. The recent studizs have revealed which part of the viral genome the host gene 
controls. A new restriction mechanism that inhibits most but not all endogenous murine leukemia viruses has been 1dentified. Various nucleotide sequencing experiments have shown that restriction or lack of it may depend on a change in a single amino acid.

Central to the mechanism of carcinogenesis are changes in gene expression. Related and of even greater imporzance is the understanding of the control of the role of gene expression in differentiation. The Molecular Carcinogenesis group has continued the study of the control of the enzyme tyrosine aminotransferase (TAT). This gene that transcribes for the enzyme begins to be expressed very actively about a day before birth in rats. It has been established that the changes prior to birth indicate accelerated transcription of the gene. Since this gene expression is not reflected in a functional form of the enzyme until after birth it is clear that the control of translation is also important. Investigations have revealed the nature of this control and the changes that take place when functional enzyme is produced.

An Interesting aspect of this translational control has been seen in studies of the hormonal control of the TAT gene. Glucocorticoids previously thought not to be involved in the activation of TAT gene expression may in fact be of importance.

The control at the translational level has been altered by 5-azacytidine and using this compound the role of methylation in the control of TAT expression has been studied.

The wel 1 established studies of hormonal regulation of gene expression in the adult have continued. Recent results s"igest that the ef fect of steroids may involve modify ation in the specific messenger RNA. Such a mode of control may be involved in the effects of other hormones.

Cloning of the TAT gene has proven to be a considerable challenge. A clone has been identified that may contain the complete gene and certainly contains part of $1 t$.

The Molecular Immunology group continues its study of changes in cells that result from malignant transformation or damage and that can be detected with a high degree of sensitivity and specificity. Identification, quantitation and manipulation of such changes can be used in a number of way 8 . For example, use can be made in the study of the changes that result in malignant transformation, the identification of transformed cells and the targeted dellvery of drugs to tumor cells, and lastly to detect and quantify damage to tissues such as the lung.

A number of techniques, lncluding monoclonal antibodies and solld state radiolmmunoassay, have been used in the characterization of tumor antigens. The aim 18 to determine the way in which these antigens arise in the process of transformation and whether their identification can be used for quantifying transformation. 
Rat tracheal cells are used to investigate markers of transformation of epithelial cells exposed to chemical agents. In this system changes in DNA content have been used to detect pre-malignant cells. This approach, added to the tracking of the changes in surface antigens, has been used in a mouse lung cell system and is providing information about both the nuclear and the surface changes that characterize the transformed cell phenotype.

Monoclonal antibodies can be bound to liposomes for targeting to tumor cells or other target cells. (Ehrlich would certainly have appreclated th1s tallored form of chemotherapy with the so-called inmunoliposomes.) A fundamental point about whether the encapsulated drug will be effective has been established. It was found that some chemotherapeutic agents are Inactivated by lysosomes, and this rendered these types of drugs ineffective whereas others are not inactivated and therefore may be suitable for therapy. Such information is essential in the design of targeted drug techniques.

For years the detection of tissue damage has been approached in a number of ways, including detection of serum enzymes or other proteins by sophisticated chromatographic techniques. A new approach to this old problem has begun in this division and involves the potential use of monoclonal antibodies for the sensitive detection of proteins released from damaged lung into the blood.

The study on the changes that occur in the process of malignant transformation that involve detection of the alterations in DNA content requires techniques for studying large cell populations with sufficient sensitivity to detect relatively small changes in a small number of cells. Flow cytometry (FCM) provides the means to carry out such an experimental approach. The study on the tracheal epithelial system is just one example of an expanding number of collaborative studies using FCM techniques that are now in progress with members of the staff of varlous sections;. Besides these collaborative studies, the group has been developing methods of data storage and also methods of cell cycle analysis.

The Chemical Carcinogenesis group has continued and extended its studies of benzo(a)pyrene metabolism found in cells of different species, especially human cells. The metabolism of $B(a) P$ by human cells 18 simflar to that by many animal cells. However, of importance are the tissuespecific differences and the Individual variations in metabolism that have been found. The Information that is accumulating about the heterogeneity of humans 18 important in deciding whether or not there really are sub groups in populations that are quite different in their susceptibility to certaln chemical carcinogens.

The determination of the precise differences in metabolic pathways In different cells within a tissue or between tissues will lead to selecting ways of amplifying or lnhibiting metabolic events ritical for transformation by a speaific chemical agent. Development ind culture of clones 
of cells that vary markedly in their metabolic activities will help to provide test systens for further studies.

The studies of the Radiation Carcinogenesis group are concerned with both the aspects of the estinate of live risks and the mechanisus of induction of cancers by radiation. Currently there is a particular interest in neutron radiation carcinogenesis. There have been suggestions that the $c$ tiates of risk of cancer as a result of exposure to neutrons have been too low and should be shanged. It was hoped that data from the survivors of the atonic bomb at Hiroshima would provide the information required for the risk estinates since the radiation fros the bonb dropped on Hiroshima was thought to consist of a mixture of neutrons and gama rays. It is now thought that there was only a very small contribution of neutrons in the doses of particular interest. As a result it is probable that any changes in protection standards will have to be based on the results of animal studies.

The Inportant questions are how to estimate the risk at low doses and what wodel can be used for extrapolation from data obtained at high doses. A new analysis of the data for the life-shortening effect indicates that the intilal slopes of the dose-response curves for both neutron and garma radiation are linear. The importance of this finding is that there wust be maximum values for the relative biological effects (RBE) of neutrons. The maximum values for RBEs will vary for cancer induction in different tissues and for specific tissues in different strains and species.

New Information has also been obtained about the effects of fractionaElon and protraction of neutrons. In the case of gamma radiation there is less than additivity when fractionation regimens are used. Our current studies are almed at explaining the greater than additivity found for some endpoints with some regimens of neutron irradiation.

The radiation arcinogenesis program has been strengthened by the transfer of Dr. M. Terzaghi from the Toxicology Section. The epithellal focus assay system developed by Terzaght and Nettesheim 18 being applied to the in vivo - in vitro studies on the radiation-induction of mammary tumors as well as the epithelial cells of the trachea. The method eriends the ablilty to detect phenotyplc changes and the sequence of alterations that occur in carcinogenesis.

In the study of ultraviolet radiation (UVR; carcinogenes1s, we have used a number of approaches. First, the development of experimental animal systems that are suitable for the investigation of different aspects of the mechanisms involved. For exampla, an opposum that is smaller than a rat has been introduced in order to determine the role of pyrimidine dimers in various UVR-induced effects, including cancer. The opossum has an efficlent photoreactivating system. Unfortunately, Dr. R. D. Ley, who has carried out these studies, left for a post with the Lovelace Medical Foundation but will remain as a consultant and as a collaborator. 
We have introduced the mutation at the hr locus into SENCAR mice and have found that this hafrless SENCAR wouse is markedly susceptible to the induction of papillomas by UVR. However, the susceptibility to carcinona induction is not greater than in one of the other hairless stocks, alihough the time of appearance is considerably earlier.

In an atteapt to discover why different stocks of hairless mice show such differences in susceptibility to squanous cell carcinoma induction by UVR, are studying the effects of UVR on the imane systen. As yet no stock-dependent differenc $?$ in the UVR sensitivity of the imme systen has been found.

The factors that influence the expression of tumors in skin are of inportance both fron a practical point of view and for the understanding of mechanisus. Skin appears to be able to suppress the expression of Initiated cells, but the ability to do so and the effect of prumoters in increasing the expression are strain-, sex- and age-dependent. For example, sex hormones influence cell proliferation in skin. It has been found that a progestin is an effective inhibitor of promotion by the phorbol ester TPA. In contrast, testosterone may enhance promotion by TPA.

The wembers of the section are involved in directing the research of graduate and postdoctoral students, some of whom are supported by the two existing Carcinogenesis training programs. In the last year a new training program in Radiation Studies with special emphasis on radiation carcinogenesis has been funded by NIH, and we look forward to recruting students in this field of research.

\section{MOLECULAR GENETICS CR CARCINOGENESIS}

$\begin{array}{ll}\text { W. K. Yang } & \text { M. Gardner I } \\ \text { R. W. Tennant }{ }^{3} & \text { C. K. Koh } \\ \text { L. R. Boone } & \text { N. Kuemerle } \\ \text { A. Brown } & \text { F. E. Myer } \\ \text { C. Y. Ou } & \text { L. Roberson } 1 \\ \text { R. Rurkes } 1 & \text { D. M. Yang }\end{array}$

The long-range goal of our research is to understand the genetic mechanisms of carcinogenesis at the molecular level. Particular emphasis is placed on the search for critical gene elements involved in the multiple genetic processes which lead ultimately to neoplastic expression of the cell, on how these gene elements are controlled in the cell and on what environmental agents may affect their expression. Progress of the three spect.fic research projects ongoing in the laboratory are summarized in the following.

Radiation-induced Leukemias of RPM/Un Mice. The RFM/Un mouse model is used because radiation causes an increased incidence of myeloid leukemias 
In these aice similar to man (8). The results of our current work on the possible role played by endogenous retroviral genes in the radiationinduced leukemogenesis are summarized in the following:

(1) An N-tropic type C retrovirus, which can be induced in RFM/Un cultured embryo cells by lododeoxyuridine treatment and which presumably represents the expression of the single ecotropic type $C$ retroviral gene locus on chromosome 5 in this mouse strain, was isolated. The genome of this endogenous viral gene was molecularly cloned by using unintegrated form I viral DNA preparations from acutely infected cells and characterized by restriction endonuclease mapping. Its ecotropic type-specific env gene sequence was subcloned. Its long terminal repeats (LTR) sequence is 527 base pairs long and presumably the smallest of marine endogeous type $C$ retroviral LTRs. The nucleotide sequence of this LTR has been deternined (4).

(i1) In our previous study, cells of an established myeloid leukemic cell line originally developed from leukemic tissues of an irradiated RFM/Un wouse (Upton line) were found to contain additional copies of the ecotropic murine leukemia virus gene integrated in DNA sites distinct from the original single copy, located on chromosome 5. To determine whether this observation represents an early event in radiation-induced leukemogenesis in this mouse strain, we made similar analyses with primary tumor tissues of Irradiated RFM/Un nice. Of about 40 individual tumors examined, about half of them showed additional ecotropic proviral integration. Histological analyses of the tumors revealed that reticulum cell sarcomas and myeloid leukemias consistently contained additional ecotropic MuLV proviral coples, whereas thymic lymphoma and a few other lymphomas showed no such phenomenon.

(11i) A lambda phage genomic library of HindIII DNA fragments prepared from normal and leukemic cell DNAs was constructed for subsequent screening and isolation of clones contalning ecotropic MuLV proviral sequences or a complete AL-10 type provirus. More than two dozen individual clones have been isolated for further characterization.

Mechan1sm of Fv-1 Gene Restriction (13). In the past year we have concentrited our efforts on localizing the genetic determinant in $\mathrm{N}$ - and $\mathrm{B}$ tropic mrine leukemla virus genomes, which render the retroviral replication susceptible to Inhibition by $\mathrm{Fv}-1$ gene products. Having igolated the genomes of individual $\mathrm{N}-$ and $\mathrm{B}$-tropic viruses we have been employing for Fv-1 studies, we made the following progress:

(1) In vitro recombinants were constructed by exchanging the homologous restriction endonuclease fragments between cloned $N$-troplc and B-tropic viral genomes; this provided a means for recognizing which particular gene segment 18 responstble for the $N$-tropic and B-tropic host range property. Our results revealed that genetic determinants of $\mathrm{N}$-troplsm and B-tropism were located in a BamHI-HindIII DNA fragment, which codes for two gag gene proteins (most of the p30 proteins except 1ts 
amino-terninal peptides, and the p10 protein and 36 aniro acid residues at the anino terninus of the pol protein [3]).

(11) Nucleotide sequence analysis (6) revealed that there is wore than $95 \%$ sequence homology in the Bami-HindIII Dil fragnent between N-tropic and B-tropic viruses. Anino acid sequences predicted fron the nucleotide seqences of $\mathrm{N}$-tropic and $\mathrm{B}$-tropic viruses revealed four differences: the 109th and llots anino acld positions of p30 were glutanine-arginine in $N$ viruses versus thi innine-glutanic acid in $B$ viruses; the 159th anino acid position of $p 30$ was glucinic acid in $N$ viruses versus glycine in $B$ viruses; the 36th anino acid position of viral polywerase protein was threonine in $N$ viruses versus isoleucine in $B$ viruses. The sequence data and che predicted anino acid changes could explain the different protein properties of the $N$ virus $p 30$ and the $B$ virus $p 30$ and also served to predict the possible protein conformational changes which way be responsible for recognition of this presumed virion target by the Fv-l gene product.

(11i) We have found in RFH/Un mice a novel restriction echanisn, called Euvr-1 locus, which inhibits oost, If not ali, endogenous ecotropic murine leukemia viruses such as RFV (endogenous ecotropic virus of RFM/Un), WN1802N and WN1802B viruses (10). However, Gross passage A N-tropic aurine leukemla virus is not susceptible to restriction by this wechanisa. To elucidate the location of the genetic determinant for the susceptibility to this restriction mecianism, we performed fragment exchange experinents, as described above in (i), and found that the genetic determinant of the susceptibility to Emvr-l restriction was present in the BanHI-HindiII genomic fragment corresponding to p30-p10- $\Delta$ pol region of the viral genome. Regults of nucleotide sequence analysis indicated that single amino acid changes might be responsible for the resistance of Gross virus to this restriction.

Carcinogen-cell Genome Interaction. Our current research efforts are focused on 1solation and characterization of germ-line associated heritable retrovirus-1ike genes which are not known to come out of the cell as a virus, and yet contain structural features characteristic of a movable gene element. He have used BALB/C mouse DNA as a source for 1solating several such Individual genes as recombinant DNA clones. Detalled analyses were performed with a particular recombinant DNA clone, called AL-10 (7). Restriction endonuclease mapping revealed that the $10.5 \mathrm{kbp}$ EcoRI insert consists of a $3.6 \mathrm{kbp}$ left flanking cellular DNA region and a $6.9 \mathrm{kbp}$ MuLV related region that has a typical proviral LTR-gag-pol-env structure up to the EcoRI site in the env gene region. Comparison of the AL-10 map with ecotropic and xenotropic virus lsolates revealed many common restriction sites in the LTR and pol gene regions, but much fewer in the leader gag region. A stretch of 1,700 nucleotides contalning the cell provirus tinc:tional region was sequenced and revealed transcriptional consensus signals and other structural features characteristic of tuLV LTRs, as well as two distinctive features. Pirst, a sequence of about 170 bp with direct and Inverted terminal repeats not seen in infectious MuLV LTRs was identified In the U3 region between the "enhancer" region and the "CAT" box. Th13 novel segment or its homologous sequences appear to be present in most of 
the endogenous WuLV-related LTRs and in other chromosomal locations of the mouse. Second, the tRMA priner binding site is not complementary to proline tRMA, the primer for 11 known MuLVs, but is a 17/18 atch with the 18 nucleotide sequence at the $3^{\prime}$ end of rat glutanine tRNA. The integration site of AL-10 provirus was in a unique DNA region but contalned an "Alu"like short interdispersed repeat in the $5^{\prime}$ adjacent cellular region. The AL-10 proviral integration found in BALB/C was also apparent in RFM, AKR and SENCAR wouse cells but not in cells of NFS/M, C3H, HRS/J, SC-I, and a Callfornia Lake Casitas wild mouse.

1. Boone, L. R., Hyer, F. E., Yang, D. M., Kiggans, J. O., Koh, C. K., Tennant, R. W., Yang, W. K., Analysis of recombinant DAA clones of the endogenous BALB/C mirine leukenta virus WN1802N: Variation in LTR length. J. Virol. 45: 484-488, $198 j$.

2. Boone, L. R., Myer, F. E., Yang, D. M., Kiggans, J. O., Koh, C. K., Tennant, R. W., Yang, H. K., Variation of LTR size in molecular clones of the BALB/c endogenous ecotropic urine leukenia virus. Prog. Nucleic Acid Res. Mol. Biol. 29: 205-214, 1983.

3. Boone, L. R., Myer, F. E., Yang, D. M., Ou, C. Y., Koh, C. K., Roberson, L. E., Tennant, R. W., Yang, W. K., Reversal of Fv-1 host range by in vitro restriction endonuclease fragment exchange between molecular cloner of $\mathrm{N}-\mathrm{tropic}$ and $\mathrm{B}$-tropic murine leukemia virus genomes. J. Virol. 48: 110-119, 1983.

4. LHou, R. S., Boone, L. R., Kuggans, J. O., Yang, D. M., Hang, T. H., Tennant, R. W., Yang, W. K., Molecular cloning and analysis of the endogenous retrovirus chemically induced from RFM/Un mouse cel! cultures. J. Virol. 46: 288-292, 1983.

5. Ou, C. Y., Molecular cluning and sequence characterization of endogeous mirine leukemia virus-related sequences of BALB/C mouse. Ph.D. dissertation, University of Tennessee-0ak Ridge Graduate School of Biomedical Sciences. pp. 144, 1982.

6. Ou, C. Y., Boone, L. R., Koh, C. K., Tennant, R. W., Yang, W. K., Nucleotide sequences of gag-pol regions that determine the $\mathrm{Fv}^{-1}$ host range property of $B A J B / C$-tropic and $B-t r o p i c$ murine leukemia viruses. J. Virol. 48: in press.

7. Ou, C. Y., Boone, L. R., Yang, H. K., A novel sequence segment and other nucleotide structural features in the long terminal repeat of a BALB/c mouse genomic leukemia virus-related DNA clone. Nucleic Acids Res. 11: 5603-5626, 1983.

8. Tennant, R. W., Boone, L. R., Lalley, P., Yang, W. K., Endogenous retrovirus and radiation-induced leukemia in the RPM mouse. Progr. Nucleic Acid Res. Mol. Biol. 29: 75-86, 1983.

9. Tennant, R. W., Lalley, P., Diaz, J., Otten, J. A., Yang, W. ..., Chromosome 5 contains the inducible ecotropic retroviral locus of RPM/Un mice. Virology, in press.

10. Tennant, R. W., otten, J. A., Wang, T. W., Liou, R. S., Brown, A., Yang, W. K., Control of RFM strain endogenous retrovirus in RFM moise cells. J. Virol. 45: 47-54, 1983. 
11. Tobaly, J., d'Auriol, L., Yang, H. K., Peries, J., Emanoll-Ravicovitch, R., Murine retrovirus genome directs the synthesis of gag protein precursor early after infection. Blochemie 64: 969-973, 1982 .

12. Yang, W. K., Introduction: Genetic echanisn in carcinogenesis. Progr. Nucleic Actd Res. Mol. Biol. 29: 1-4, 1983.

13. Yang, W. K., Boone, L. R., Tennant, R. W., Brown, A., Restriction of murine leukenia viruses by Fv-1: A wodel for studying host genetic control of retroviral gene movement and leukenogenesis. Prog. Mucleic Acid Res. Mol. B1ol. 29: 175-192, 1983.

\section{REGULATION OF GENE EXPRESSION}
F. T. Kenney
K. -L. Lee
L. A. Baloghl
K. R. Ishan
G. R. Holloway
L. A. Stringfellow 4
A. C. Johnson 1
R. S. Rothrockl 1
M. H. Tinda 7

The objective of this research is to define in molecular terms the mechanisms controlling expression of specific genes in mammalian cells. We study how gene expression is activated in the process of differentiation, how tissue-specific expression is effected, how expression is modulated by hormones and other specific effectors, and how genetic control mechanisms are altered in the dysfunction of gene expression in cells transformed to malignancy. Much of our work is focused on expression of the rat liver enzyme tyrosine aminotransferase (TAT), a convenient model since its expression is modulated in several important ways and the system is amenable to detalled blochemical analysis. Significant progress has been made in a number of experimental approaches.

Differentiation. Our analysis of the activation of TAT gene expression during the perinatal period of development in rat liver now provides a clear picture of the sequence of events, as follows: (1) the TAT gene is expressed to a very limited extent in late term fetal 11 vers $(18,19$, 20 days gestation), hybridizable transcripts, functional mRNA, and enzyme all belng present at levels 10- to 15-fold below adult; (2) hybridizable transcripts begin to increase in the $218 t$ day, are several-fold above fetal levels in the 22nd day (usual day of dellvery), and are at or above adult levels in newborns. These changes are virtually identical in both nuclear and cytoplasmic RNAs, in accord with the conclusion that the increase reflects accelerated transcription of the TAT gene. However, these transcripts are not functional in the liver cell (as no increase in enzyme is observed at this time), and they are similarly non-functional when assayed by translation in reticulocyte lysates; (3) the transcripts are converted to functional form beginning in the first few hours after birth. By 12 hours both mRNATAT (assayed by translation) and enzyme are well above adult levels, to which they decline as the steady-state is established 24 to 36 hours after birth. 
These results provide a clear indication of translational control superimposed upon transcriptional control and temporarily operating to limit full expression of the TAT gene products. Post-mitochondrial supernatants of homogenates of livers from newborns were fractionated on sucrose gradients and analyzed for TAT sequences by cytoplasaic dot hybridizations. This analysis reveals that the non-functional sequences are not polysone-bound, but rather appear to be present as mRNP particies that sediment between the ribosomal subunits and the intact $80 \mathrm{~S}$ ribosome. In the hours after birth we see a shift of these sequences into the polysomes, in accord with increased enzyme production and translatability as assessed in the lysate system. It is significant that these changes in specific TAT production are mirrored by what appears to be a corresponding change in the total capacity for translation. In newborns the polysome populacion is markedly reduced, the bulk of the ribosomes being present in monomeric form. The relationship between this indication of a generalized defect in initiation and our observations on TAT expression remains to be established.

Earlier analyses have shown that TAT expression in fetal liver is refractory to induction by glucocorticoids, in terms of either anzyme production or translatable mRNA. However, we now find that gene transcripts are indeed synthesized in response to hydrocortisone in 20 or 21 day fetal livers; dot hybridizations reveal an increase in transcripts that is quite comparable to that seen in adults. That these transcripts are not functional either in vivo or in vitro again points to a translational control mechanism operating to limit full expression and perhaps involvin a modification of mRNA Th structure. These results also refintroduce the question of a glucocorticoid involvement in developmental activacion of TAT gene expression, which we had thought could be excluded from consideration.

Changes in DNA methylation have been implicated in differentiationassociated activation of gene expression in a number of experimental systems. We have found that direct treatment of 20-day fetuses in utero with the methylation Inhibitor, 5-azacytidine, has profound effects on hepatic differentiation. TAT expression is fully activated 18 hours after treatment. Hybridizable transcripts are at or above adult levels, indicating a demethylation-induced acceleration of TAT gene transcription. These transcripts are fully active in translation assays and in the hepatocyte, as enzyme levels are increased some 70 -fold above age-matched fetuses. These results indicate that the drug somehow obviates the translational block normally operating in fetal liver. Analogs of cytidine that are also toxic but do not af fect DNA methylation have no ef fect on TAT expression. The drug 18 not very effectlve if given to fetuses earlier than 20 days of gestation, implying a temporally programmed change in "competence" that is independent of methylation, and in accord with results of others that demethylation way be necessary but not sufficient for transcriptional activation.

It was observed that the gross appearance of fetal livers was changed after 5-azacytidine treatment, which led to evaluation of several 
paraneters other than TAT expression. Histological studies show a change in liver structure that is truly dramatic. Hematopoletic elements are not obviously affected, but hepatocytes are greatly enlarged, basophilic, and arranged in the sinusoidal pattern that is not apparent in untreated controls. Glycogen is markedly reduced and stored lipid droplets have increased, as seen both by histochemical staining and EM studies; the latter also show an enhancement of both smooth and rough ER following treatment. Assays for other developmentally activated "liver-specific" enzymes show a marked increase in phosphoenolpyruvate carboxykinase but little or no change in glucose-6-phosphatase or tryptophan dioxygenase, but these analyses must be supplemented by measurements of gene transcripts to be fully understood. Taken together, the data indicate that the demethylating agent advances by several days the programmed maturation of the hepatocyte.

Tissue-Specific Gene Expression. This aspect of our studies in differentiation was initiated this year. TAT is said to be "liverspecific" but previous studies of its expression in otier tissues are not definitive. We have scanned a variety of rat organs for TAT gene expression, assaying for two parameters. Presence of the TAT protein is assessed by "Western" blotting of electrophoretic gels and probing with antibody to TAT followed by 125 -protein $A$ to detect the immobilized antibody; this immunological assay ove:comes difficulties in interpretation of activity measurements. TAT gene transcripts are measured by dot hybridizations and, when appropriate, by "Northern" blotting to determine the size of the transcripts. Three organs have been selected for further analysis. Liver, in which expression is maximal, is considered a positive control, and testis, wherein expression of either parameter is at background levels, is represantative of tissues in which the gene is essentially silent. Kidney has been found to display a most interesting intermediate level of expression. Enzyme is not detectable. Total RNA preparations, or poly(A)RNAs extracted from total RNA, contain a level of hybridizable sequences nearly equivalent to those in liver. However, when nuclei were excluded by preparation of cytoplasmic RNAs from kidney, the sequence level was far below (perhaps 100-fold) the liver. These results imply that in kidney the gene is being transcribed but, probably as a consequence of defective nuclear processing, very few or no functional mRNA molecules enter the cytoplasm and are translated.

Hormonal Regulation. Our analyses of induction of TAT synthesis in adult livur by hydrocortisone have revealed some interesting complexities that are as yet poorly understood but hold the promise of explain'ing some of the unexpected phenomena we observe in studies of differentation. First, the accumulation of cytoplasmic transcripts detectable by hybridization 18 much more rapid and extensive than are increases in either translatable mRNA or enzyme. Secondly, as the Induction process proceeds, there appears to be accumulation of a second form of mRNATAT as seen on "Northern" blots; this species is somewhat smaller (3000 v8 3400 nucleotides) and appears to correlate with increased translational activity of the mRNA and enzyme production. These results, currentiy being confirmed and extended, suggest a requirement for a cytoplasmic nodification of 
mRNATAT resulting in both its shortening and activation of its capacity to be translated; perhaps such a mechanism is involved in the developmental shift of aRNA TAT from mRNP particles to functional polysomes. An alternative, that steroid induction involves transcription from a different promoter and thereby a different (smeller) aRNA, cannot be excluded.

Studies of Induction by cyclic AMP and by insulin are nearing completion. In both we see a very rapid accumulation of hybridizable transcripts, again preceding accumulation of translational capacity or of enzyme. The enhancement of TAT synthesis induced by cAMP is completely accounted for by increased accunulation of mRNATAT in both cytoplasinc and nuclear RNA preparations, making it most likely that this induction mechan1sm is also primarily transcriptional. Surprisingly, cAMP treatment renders the already labile $\mathrm{mRNA}^{\mathrm{TAT}}$ (intracellular $t 1 / 2$, ca $90 \mathrm{~min}$ ) even more labile in vivo ( $1 / 2$ ca $20 \mathrm{~min}$ ). This effect is not seen with the other hormonal Inducers, and as yet we can offer no explanation. Analyses of these inductions in terms of the newly-discovered multiple species of mRNA ${ }^{\text {TAT }}$ have not yet been done.

Genomic Cloning. To define fully expression of the TAT gene, changes in expression during development, as induced by hormones or its expression in different tissues, it will be necessary to isolate the gene and to characterize 1ts structure. Restriction analysis of rat DNA has established that TAT is a single copy gene. A library of fragments of rat DNA cloned in phage lambda was kindly made avallable by Dr. James Bonner, California Institute of Technology. After extensive screening of nearly $2 \times 10^{6}$ placques, one was identified (by hybridization to $32 \mathrm{p}$-labeled cDNATAT, as carrying at least a portion of the TAT gene. This clone is currently belng purified preparatory to characterization of the fragment of rat DNA by restriction mapping. It is concelvable, but we think unlikely, that this fragment contains the entire gene; it will probably be necessary to use the fragment now identifled to rescreen the library for contiguous fragment 8 .

To characterize the gene structure it w1ll be necessary to have aval1able a full length cDNATAT. The cloned cDNA now avallable is representative of only the $3^{\prime}$ third of mRNA ${ }^{T A T}$ and will not recognize the $5^{\prime}$ portion of the gene, the region wherein key regulatory elements could be expected. We have now worked out procedures for producing a CDNATAT representing the region of the messenger not recognized by our current probe. This was done by priwir extension of a small fragment, and the product is full length or nearly 80. This cDNA is now being prepared for cloning to produce the reagent in quantity. When avallable, it will also be very significant in analyzing intermediates in processing of TAT gene transcripts, a research objective that has not been successful with our current cDNA probe.

1. Donohue, T. M., Jr., Lee, K.-L., Kenney, F. T., Conconavalin A alters the turnover rate of tyrosine aminotransferase in cultured hepatoma cel1s. 310chem. Blophys. Acta 721: 94-100, 1982. 
2. Perry, 5. T., Rothrock, R., Isham, K. R., Lee, K.-L., Kenney, F. T., Development of tyrosine aminotransferase in perinatal rat liver: changes in functional mRNA and the role of inducing hormones. J. Ce11. Blochem. 21: 47-61, 1983.

3. Rothrock, R., Perry, S. T., Isham, K. R., Lee, K.-L., Renney, F. T., Activation of tyrosine aminotransferase expression in fetal liver by 5-azacytidine. Blochem. Blophys. Res. Commun. 113: 645-649, 1983.

TUMOR CELL SURFACE PROTEINS

\author{
S. J. Kennel \\ G. R. Braslawsky \\ R. Flynn 1 \\ L. J. Foote
}

J. A. Hotchkisg 1
A. H. L. Huang
P. K. Lankford

Tujor Antigen Characterization. Cell surface proteins mediate Interaction between cells and their environment. Unique tumor cell surface proteins are being Identified and quantified in several tumor systems to address the following questions: (1) How do tumor-specific proteins arise durlng cell transformation? (11) Can these proteins be used as markers of tumor cell distribution in vivo? (iii) Can solid state radiolmmunoassay of these proteins provide a means to quantily transformation frequencies?

A tumor surface protein of $180,000 \mathrm{M}_{\mathrm{r}}$ (TSP-180) has been identified on cells of several lung carcinomas of BALB/C mice. TSP-180 was not detected on normal lung tis3ue, embryonic tissue, or other eptthelial or sarcoma tumors, but it was found on lung carcinomas of other strains of mice. Considerable anluo acid sequence homology exists among TSP-180s from several cell sources, Indicating that TSP-180 synthesis is directed by normal cellular genes although it is not expressed in normal cells. The regulation of synthesis of TSP-180 and its relationship to normal cell surface proteins are being studied.

Monoclonal antibodies (MoAb) to TSP-180 have been developed. The antibodies have been used in immunoaffinity chromatography to isolate TSP180 from tumor cell sources. This purifled tumor antigen was used to Immunize rats. Antibody produced by these animals reacted at different sites (epitopes) on the TSP-180 molecule from those with the original MoAb. MoAb to several epltopes on TSP-180 are being used to identify normal cell components related to the TSP-180 molecule through quantitative absorption and immunohistochemical techniques.

Drug Targeting and Tumor Imaging. Antibody reagents reacting specifically with tumor antigens should "home" to target cells in vivo. Using radiolabeled antibody, tumor cells and thelr metastases can be located by radiolmaging. Pure antibody reagents needed for these studies are now avallable in the form of MoAb. A detalled study of interaction of MoAb witi cell surface antigens has been done in three different tumor systems. 
These results show that quantitatively the interaction follows a simple mass action expression for bimolecular reactions. Thus for effect 1 ve tumor imaging, the factors that are important are (1) the purity of the label $2 d$ antibody, (11) the affinity constant of the antibody, and (i1i) the antigen concentration of the tumor cells.

If antibodies can localize at tumor cell sites, they should be useful for delivery of cytotoxic chemicals to the tumor cells. Intermediate carriers, such as liposomes, should allow iarge numbers of drugs to be delivered by a limited number of antibody molecules. Monoclonal antibodies have been derivitized with fatty acids and attached to liposorea.

With this method we have covalently attached a monoclonal antibody (11-4.1) agalnst the mirine major histocompatibility antigen, $H-2 K^{k}$, on the surface of liposomes. The interaction of these antibody-coated liposomes (immunoliposomes) with target $r: 11 s$, RDM-4 lymphoma ( $\mathrm{H}-2 \mathrm{~K}^{\mathrm{k}}$ ), was investigated. About $90 \%$ of the immuroliposomes taken up by target cells at $4^{\circ} \mathrm{C}$ couid be removed by a mild protease treatment of the cells; whereas only $30 \%$ of the uptake at $37^{\circ} \mathrm{C}$ was labile to the same treatment. Furthermore, the uptake of immunoliposomes at $37^{\circ} \mathrm{C}$ was inhibited by cytochalasin $B$ or by a combination of 2-deoxyglucose and $\mathrm{NaN}_{3}$. These results suggest that immunoliposome binding to the target cell surface is the primary uptake event at $4^{\circ} \mathrm{C}$ and that the surface bound liposomes are rapioly internalized by the cells at $37^{\circ} \mathrm{C}$, probably via an endocytic pathway. Studies with fluorescence microscopy of target cells treated with 1mmunollpczomes contalning carboxyfluorescein also supported this conclusion. If endocytosis is the mechanism by which Immunoliposomes gain entry into target cells, the efficacy of a cytotoxic drug encapsulated wotld depend on the resistance of the drug to lysosomal inactivation and its ability to escape from the lysosomal system. Consistent with this notion, we observed that methotrexate (MTX) encapsulated in liposomes bearing $11 .-4.1$ antibody specifically inhibited deoxy $\left[6-{ }^{3} \mathrm{H}\right]$ uridine incorporation into DNA Iri target RDM-4 cells but not in P3-X63-Ag 8 myeloma cells (H-2Kd) at the same doses. The observed cytotoxic effect of encapsulated MTX could be reversed by the treatmcnt of cells with a lysosomotropic amine, chloroquine, which has been shown to increase the intralysosomal $\mathrm{pH}$ of mammalian cells. On

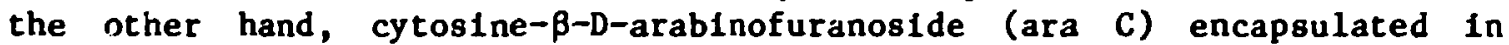
immunoliposomes showed no target srectfic killing, probably becalise the drug 18 readily inactivated in the lysosomal system. This basic informatior: is Important for future design of a more effictent drug delivery Bystem.

Tumor Therapy with MoAb. Mice were treated with monoclonal antibody to TSP-180 in an attempt to prevent artificlal lung metastasis formaticn from intravenous injection of ti'mor cells. This passive immuntzation was not effective. Several factors, Including antibody class and subclass, antibody specificity, tumor antigentcity and amount of antibody adminIstered could be important factors.

In another system, syngenelc monoclonal antibodies (MoAb) to Muloney sarcoma cells (MSC) were produced by fusion of spleen cells from MSC 
regressor mice to myeloma SP2/0. MoAb 244-19A, an immunoglobulin $G_{2 b}$ bound to MSC cells and did not bind to two other sarcomas (K-BALB and Ha2), a carcinoma (Line 1), a fibroblast (A31) or a fibroblast infected with C-type virus (A31-Moloney leukemia virus). In contrast, MoAb 271-1A bound to the MSC and Ha2 sarcoma and Line 1 carcinoma as well as to the normal and infected fibrcblast cultures. Antibodies were tested for therapeutic effect using three schedules of antibody injection. Intraperitoneal injection of ascites fluid containing 244-19A MoAb given on days $-1,0$, and +1 relative to tumor cell injection, increased life span significantly over that of control animals given injections (P3, immunoglobulin G, or MoAb 271-1A) and produced seven of 19, one of five, and one of five long-term survivors in three separate experiments. Antibody given to animals with established tumors ( 4 days after implantation) also prolonged iffe span significantly and produced three long-term survivors of nine treated animals. Antibody given to aimals with very large tumor burdens ( 10 days after implantation) did not prolong life span significantly. Optimal dose, schedule, and mechanism studies concerning this therapy are in progress.

Solid State Radiolmmunoassay for Carcinogenesis. Tumor-specific proteins represent cell phenotypes c.aracteristic of cell transformation. Quantitation and sensitive detection of these proteins should provide a meth:sd of early detection of transformation. Automated solid state radioimmunoassay techniques have been developed that can be used to screen thousands of cell clones for transformed phenotypes. Assays using monoclonal antibody coupled to solid supports should allow assay of more than $10^{6}$ cells at a time. Details of solid state assays with MoAb have been worked out. Affinity constants of antibodies for antigen in fluld phase or coupled to a solid support do not vary significantly; however, antigen presentation on solid $s$ pports depents on the configuration of the support as well as the mode of attachment of the antibody. Monoclonal antibody to fragme.it $D$ (FgD) of human fibrinogen has been used to develop a solid state assay for FgD which should be diagnostic of plasminogen activicor activity, Although the affinizy constant of the specific MoAb is relatively low $\left(10^{7} 1 /\right.$ mole), the assay has been made sensitive at the $\mathrm{ng} / \mathrm{ml}$ range by coupling the spceific MoAb with non-specific antibodies of high affinity $\left(1.1 \times 10^{10} 1 /\right.$ mole $)$. This assay should be useful in screening clones of cells for plasminogen activator activit; and for analysis of serum $\mathrm{FgD}$ levels in cancer patients.

Monoclonal Antibody for Lung Toxicology. Analysis of toxic infury to lungs can be obtalned chiefly through invasive procedures, such as biopsy or at autopsy. In contrast, assay of enzyme levels in serum has proven to be diagnostic of liver damage. The enzymes found in serum are those released from damaged or regenerating llver cells. If antibodles to lung epecific proteirs can be developed, they may be useful as reagents to detect lung proteins in serum as a function of toxic infury. Rat MoAb to moise lung proteins have been isolated from rats lmunized with several different lung protein immunogens. These antibodies are currently being analyzed for their binding specificity and for their suitability for assays of lung proteins released into the serum of toxin treated animals. 
Study of Intigenic Markers in Developing Neoplasia. Most malignant tumors in man arise from epithelia via a iltistep process, in which new cell populaticns with altered biological and morphological properties appear. The jurpose of this researc' project is to define and quantify cellular markers that can identify chentcally altered cell populations appearing in transformation of rat trachea epitielial cells, and to delineate their role in the development of nenplastic cell populations. Identification of such markers would not only afd in understanding preneoplastic disease, but also offer new approaches for detection and quantitation of such alterations in cells exposed to putative oncogenic agents well before the appearance of the neoplastic phenotype. Our approach has been to define early phenotypic changes in short-term cultures of rat tracheal epithelial cells exposed to chemical carcinogens. Altered phenotypes have been identffied on the basis of an increase in nuclear DNA content as compared to non-altered cells and expression of antigen that 18 not detected on normal cells. These changes appear early, occurring in precursor cells that eventually give rise to neoplastic populations and correlate with the initial breakdown of those mechanisms which regulate normal growth and differentiation. Our goals are to be able to predict the probability of neoplastic cell types appearing in exposed cell populations well before the appearance of the malignant cell phenotype.

1. Braslawsky, G. R., Kennel, S. J., Netteshe1m, P., Phenotyplc changes in epithelial cell populations undergoing neoplastic progression In vitro, in Cohn, W. E. (ed.): Prog. Nucleic Acid Res. Mol. Biol., Vo1. 29, Academic Press, Inc., New York, 1983, pp. 262-265.

2. Huang, L., Kennel, S. J., Coupling of antibody with liposomes, in Gregorladis, G. (ed.): Liposome Technology, CRC Press, Boca Raton, Florida, in press.

3. Huang, A., Kennel, S. J., Huang, L., Interactions of Immunoliposomes with target cells. J. Biol. Chem., in press.

4. Huang, A., Kennel, S. J., Huang, L., Preparation of immunoliposomes, In Reid, E., Cook, G. M. W., Moore, D. J. (eds.): Membrane-Located Receptors for Drugs and Endogenous Agents, vol. 13, Plenum Press, New York, in press.

5. Huberman, E., Braslawsky, G. R., Callaham, M., Figik1, H., Induction of differentiation of human promyelocytic leukemia (HL-60) cells by teleocidin and phorbol-12-myistate-130 acetate. Carcinogenes1s 3: $111-114,1982$.

6. Kennel, S. J., Foote, L. J., Lankford, P. K., Johnson, M., M1tchell, T., Braslawsky, G. R., Direct binding of raúlolodinated monoclonal antibody to tumor cells: Significance of antibody purity and affinity for drug targeting. Hybridoma, in press.

7. Kennel, S. J., Lankford, P. K., Solld phase radiolmunoassay of fragment $D$ of human fibrinogen using a low affinity monoclonal antibcdy. Clin. Cher. 29: 778-781, 1983.

8. Kennel, S. J., Lankford, T., Flynn, K. M., Therapy of a murine sarcoma using syngeneic monoclonal antibody. Cancer Res. 43: 2843-2848, 1983. 
9. Mann, R. C., Hard, R. E., Jr., Braslawsky, G. R., Paranetric analysis of histograns measured in flow cytometry. Cytometry 4. 75-82, 1983.

10. Netteshe1m, P., Braslawsky, G. R., Steele, V. B., Rennel, S. J., Cell population studies during eptthellal carcinogenesis, in Owens, $R$. (ed.): Tumor Celi Heterogenelty: Origins and Implications, Vol. 4, Acadenfc Press, New York, In press.

\section{CYTOMETRICS}

R. Mann R. E. Hand, Jr.

The Cytometry Group concentrates its activities on work that is related to the operation of a state-of-the-art multi-user facility for flow cytometry ( $F C M$ ) and cell sorting. During the third y sar of its existence, the group has continued to pursue two major goals: (1) to engage in collaborative work with different groups in the Division applying FCM, and (2) to perform Independent research developing new cytometric techniques. Efforts towards achieving the latter goal have been concentrated mainly on problems in FCM data analysis and interpretation, and on new sample preparation techniques for FCM.

We have addressed three problem areas in FCM data analysis: (1) analysis of one- and two-parameter histograms, (2) comparison of histograms, (3) effictent processing of large volumes of mult1-parameter data.

Histograms frequently consist of several components that show varying degrees of overlap. The maln task of histogram analysis is to identify these components. Our major progress has been in the area of analysis of DNA-h1stograms. Several algorlthms in the literature were 1mplemented on the computer system in the FCM laboratory to analyze DNA distribution of nomogeneous cell populations. They are being used for research by several Invest1gators (W. Au, G. R. Braslawsky, D. M. Popp, R. A. Popp, J. K. Selk1rk). The need to analyze DNA-h1stograms obtained from heterogeneous cell populations (in collaboration with G. R. Braslawsky) led to the formulation of a new method for the Identification of histogram components. The method 18 based on maximum likellhood estimation, and 18 also applicable to two-parameter histograms. Preliminary investigations have shown that the two-dimensional version of this method will most probably be used for the measurement of spot intensities in the automatic electrophoret1c gel analysis system that will be avallable soon in the Chemical Carcinogenesis Croup.

The detection of significant differences between histograms or groups of histograms is another problem in FCM data analysis that arises in many different applications. We have adapted Fisher's randomization test to compare two groups of one-parameter h1stograms. The method is not restricted to a particular form of histogram, and is therefore applicable to any type of one-parameter data pattern measured with our instrument. 
Research is under way to develop a corresponding method for the comparison of two-parameter data.

Mult1-parameter $(>2)$ measurements are being made in more than half of the experiments using FCM. Data are collected in LIST mode, 1.e. data are stored in form of a list containing the parameter values for each individual cell measured. The amount of memory required for these measurements Is therefore proportional to the product of the number of cells and the number of parazeters per cell. In a typical experiment 50,000 to 100,000 cells are measured per sample. Data from the different Invescigators' experiments are currently stored on 18 magnetic disks (5 Mbyte/disk) and 8 magnetic tapes, and these numbers are increasing. We are thereiore investigating methods for compact data storage, data dimensionality reduction, and optimal display of multi-parameter data. Progress has been made in compact storage, and the application of projections for dimensionality reduction of FCM data.

A major improvement has been achleved in the speed of analysis of large volumes of data by establishing a "soft" link via magnetic tape between the minicomputer in the FCM laboratory and the main computer in the Division.

We were fortunate to obtain from Mr. Howard Gratzner, Institute for Ce11 Analysis, Miami, Florida, a sufficient amount of bromodeoxyuridine (BrdU) specific monoclonal antibody that enabled us to implement a new assay for cell cycle analysis (recently developed at Lawrence Livermore National Laboratory), and to explore further FCM assays involving BrdU. BrdU is a compound that is incorporated Into DNA during synthesis or repair as a substitute for thymidine. Therefore f.t quenches the fluorescence of the adenine/thymidine-specific Hoechst 33258 stain. This effect can be measured, thereby quantffying the amount of incorporated BrdU Into DNA, and hence, repalr or synthesis. There are problems with this assay, however, due to low quantum yleld and the need for high power UV excitation. With the BrdU specific monoclonal antibody that is labeled with fluorescein isothlocyanate (FITC), it is possibie to measure the amount of incorporated BrdU by excitation with visible light $(488 \mathrm{~nm})$. So far the antibody has been used for cell cycle analysis measuring the amount of incorporated BrdU during S-phase and total DNA (stalned with propidium lodide). The addition of the second (FITC-labeled antibody) fluorescence parameter allows a determination of the fraction of cells in S-phase much more accurately than by raasuring DNA content alone. Preliminary experiments (in collaboration with J. D. Regan) suggest that DNA repair in human fibroblasts after Irradiation with different doses of UV light can be quantified by flow cytometry with the BrdU-specific antibody.

Together with Wayne Greene, DiaClin Laboratory, Nashville, Tennessee, we organized the flrst regional PCM users meeting which was held on September 23, 1983 in Oak R1dge. The goal of this meeting was to provide a reglonal forum in which all levels of laboratory $p$ rsounel can gather to dlscuss current inserumentation, techniques, and appllcatons relating to 
flow cytometric analyses in both research and clinical situations. It is planned to hold these meetings semi-annually in the future.

1. Mann, R. C., Mathematical methods in flow cytometry. Feodor-Lynen Fellowship Report, Alexander von Humboldt-Foundation, Bonn, FRG, 1983.

2. Mann, R. C., Slit-scan flow cytometry: separability properties of cell features. Cytometry 3: 257-261, 1983.

3. Mann, R. C., Hand, R. E., Jr., The randomization test applled to flow cytometric histograms. Comput. Progiams Biomed., in press.

4. Mann, R. C., Hand, R. E., Jr., Braslawsky, G. R., Parametric analysis of histograms measured in flow cytometry. Cytometry 4: 75-82, 1983.

\section{METABOLIC ACTIVATION AND CARCINOGEN IETABOLISM}

$$
\begin{array}{ll}
\text { J. K. Selkirk } & \text { B. K. Mansfield } \\
\text { S. Tong } & \text { P. A. Noghrei-Nikbakht }
\end{array}
$$

Research into the metabolism of chemical carcinogens has clearly shown a striking simflarity for all eukaryotes with regard to the enzymatic pathways that are utilized to metabolize xenobiotics, and the final array of metabolic products. Cur studies over the past year have been designed to more carefully define the metabolic differences in diverse tissues, both human and rodent, for the activation and detoxification of polycyclic carcinogens as major environmental contaminants of energy production from fossil fuels. Our goal is to probe and possibly amplify differences in metabolic pathways in order to determine what portions of the metabolic activation profile are critical to forming, maintaining, and directing the ultimate carcinogenic species toward its final fate. Benzo(a)pyrene is being uced as the prototype molecule to formulate a mechanism which describes how individual systems transform the parent chemlcal into a highly reactive electrophile. Benzo(a)pyrene forms a particularly active diol-epoxide as one of its many metabolites. This reactive intermediate is thought to be the principal carcinogenic spectes for this polycyclic molecule, and is based on enhanced carcinogenic and mutagenic activity when compared to the parent molecule. The diol-epoxide is also the major form of benzo(a)pyrene that binds to nucleic acid. However, this structural information has been insufficient to formulate an explanation of how this alkylation process triggers malignant transformation. The fact that both resistant and susceptible tissues form the same carcinogenic diol-epoxide intermediate points to quantitative variation in the amount of the carcinogenic intermediate formed as a critical parameter, which helps determine whether a tissue or cell will becore malignanty transformed. During the past year, we examined benzo(a)pyrene metabolism and DNA binding in both human and rodent cells. Since human exposure to carcinogenic polycyclic hydrocarbons continues to be a major environmental hazard, it is important to know if specific tissues in the body are at greater risk than 
other tissues or organ systems. We studied metabolism in explants of four human tissues: bladder, skin, bronchus and esophagus from eight donors sampled 4 hours after death. Explants were incubated with tritiated benzo(a)pyrene and the metabolites extracted and analyzed by high pressure liquid chromatography. Fibrohlusts were grown from explants from two patients and also incubated with benzo(a)pyrene in order to compare differences between differentiated and undifferentiated cells. Averaging the percent yield of each metabolite for each individual tissue between the eight donors showed remarkably comparable ratios for all the major metabolites. In general, the human tissue profiles were quite similar to the majority of the non-human profiles reported in the literature, including the formation of the 9,10-dihydrodiol as the major cellular metabolite. Undifferentlated fibroblasts cultured from esophagus, skin, bladder and bronchus from two patients yitlded the same metabolite profile as seen in the epithelial cultures. The amount of carcinogen bound to tbe DNA in these four tissues showed a wide variability in specific activity of binding between individual donors. There also seemed to be differences in variance between the four tissue studies. Variability between individual tissues showed bladder to have the widest range of specific activity (10183; sk1n, 5-82; bronchus, 10-60; esophagus, 2-42). Interestingly, the level of activity for the four tissues was relativeiy the same in a given Individual (e.g. four high values or four low values), which may reflect a genetic variance at the Ah locus for monooxygenase induction. These results clearly show that the heterogeneous human population possesses a wide range of metabolic competencies for inducing the drug metabolizing enzymes, and concomitantly the formation of carcinogenic intermediates. Assuming qualitative patterns of carcinogen activation to be the same, we must increasingly probe individual differences between resistant and susceptible cells for metabolic activation. This will help to determine if there are sub-groups in the population more susceptible to environmental exposure to carcinogens. Since liver cells are the prime site for metabolism of xenobiotic chemicals and are not favored sites for tumor formation by environmental carcinogens, we probed the high metabolic competency of normal and malignant liver cells. Furthermore, wc utilized the liver cell metabolic products in a short term mutagenesis assay. These studies utilized different cell lines derived from BD-IV and BD-VI rats in collaboration with the International Agency for Research on Cancer in Lyon, France. We utillzed a non-transformed liver line (IAR-20) and compared it agalnst four tumor lines derived from that parent cell (IAR-6-1, IAR-19, IAR-27, IAR-28). Cultures were treated over a 5-day period, and the cells and medium analyzed for the level of metabolism and the distribution between organic soluble Intermediates and water-soluble excretion products. The varlous cell cilturcs were tested for survival over a 5-day perlod to see if the transformed lines processed the carcinogen to more cytotoxic products in a parent (IAR-20) cell line. Survival rates over the 5-day Incubation period and overall benzo(a)pyrene me::abolism produced an inverse relationship. More metabolism resulted in less survival due to the greater production of toxic intermediates. However there were some inconsistencies over the 5-day period. Analysis at the 5-day time period showed some of the cell populations were producing the same level of metabolism with only half the cell population as the parent cell line. Time course studies of 
the formation and disappearance of each metabolite in the array of benzo(a)pyrene diols, phe.sols, and quinones showed continual buildup of the benzo(a)pyrene diols which appeared to be less active substrates for water-soluble conjugation to glutathione or glucuronide. Phenols and quinones peaked at 24 hours, and elther maintained a steady state of formation and disappearance or in some cases, exhibited a gradual decline over the 5-day perlod. Our previous studies have shown the phenols of polycyclic carcinogens to be good substrates for conjugation to watersoluble products.

We also monitored this metabolism for the amount of carcinogen bound to nuclear macromolecules. While aikylaton of DNA/RNA nuclear protein is dependent upon a complex series of enzymatic and chemical steps that control the amount of avallable activated intermediate at any given time, it is important to know if the attack on nuclear material can be directly approximated to the amount of metabolism by the cellular monooxygenases. Interestingly, the protein/DNA ratios were fafrly constant, but there were major differences in the amounts of DNA bound. As an example, IAR-20 ind IAR-6-1 showed an equivalent DNA and protein binding ratio ( 1.55 vs. 1.57 ) in which the IAR-6-1 was able to accomplish this with half the metabolism of the IAR-20. IAR-2-19 showed a relative increase in binding with an increase in overall metabolism, although not proportionately since the binding increase was about $30 \%$, while metabolisw increased only 13\%. In addition, we saw further variation with the spontaneously transformed line IAR-27, which showed the lowest DNA and protein binding along with a significant change in the protein/DNA binding ratio. That was coupled to a metabolism equivalent to IAR-6-1. Primary hamster embryonic fibroblasts which were utilized for comparison showed greater than twice the binding of th: most active liver epithelial line, but was accompanied by an overall metabolism roughly equivalent to the parent liver line, IAR-20.

The complex metabolism seen in these liver cell lines shows that interrupting a single step of the cumplex biochemical scheme that is responsible for controlling metabolism of chemical carcinogens may inhibit the activation pathway in favor of accumuation of one or more hydroxylated intermediates. This was observed when these liver cell lines were used as activators in the $V 79$ mutation cell assay where, as predicted, the more active parent cell, IAR-20, induced a three-fold higher mutation rate than in the poorly metabolizing spontaneous trarsformant, IAR-27. Our present approach to the concept of selective susceptibility and resistance to chemical carcinogens has enabled us to formulate a new approach to study subpopulations of cells within target tissues or organs in order to isolate and amplify those metabolic parameters that are critical for directing a cell to become malignantly transformed. We are now utilizing the fluorescence Activated C.11 Sorier in the Blology Division to sort populations of cells based on their ability to clear polycylic hydrocarbons from the cytoplasm after short term incubations. This is indicative of varying metabolic activity in the cytoplasmic monooxygenases. In this manner, we will separate clones of cells in vastly different blochemical conpetencies from a high background of "norma! cell" metabolism. By selecting out these biochemically aberrant cells, we hope to determine which portions of the 
metabolic scheme have been altered. We can then propagate these cell lines to compare their transforning ability and their complete metabolic profiles.

1. Kootstra, A., MacLeod, M. C., Iyer, R., Selk1rk, J. K., Slaga, T. J., Select:ve modification of nuclear proteins by $B(a) P$ diol-epoxides and other polycyclic aromatic hydrocarbons. Carcinogenesis 3: 821-824, 1982.

2. Macleod, M. C., Mansfield, B. K., Selkirk, J. K., Time-course of metabolisw of benzo(a)pyrene by hamster embryo cells and the effect of chemical modifiers. Chem.-Biol. Interact. 40: 275-285, 1982.

3. MacLeod, M. C., Pelling, J. C., Slaga, T. J., Noghrei-Nikbakht, P. A., Mansfield, B. K., Selkirk, J. K., Specificity of interaction between carcinogenic polynuclear aromatic hydrocarbons and nuclear protein: widespread occurrence of a restriction pattern of histone-binding in intact cells, in Cohn, W. E. (ed.): Prog. Nucleic Acid Res. Mol. B1ol., Vol. 29, Academic Press, New York, 1983, pp. 111-115.

4. MacLeod, M. C., Selkirk, J. K., Physical interaction of isomeric benzo(a)pyrene diol-epoxides with DNA. Carcinogenesis 3: 287-292, 1982.

5. Schuresko, D. D., Griffin, G. D., MacLeod, M. C., Selkirk, J. K., Enhanced benzo(a)pyrene metabolism in hamster embryonic cells exposed in culture to fossil synfuel products, in Polynuclear Aromatic Hydrocarbons, Battelle Press, Columbus, Ohio, 1982, pp. 725-734.

6. Selkirk, J. K., MacLeod, M. C., Chemical carcinogenesis: An error in natural protection. BioScience 32: 601-605, 1982.

7. Selkirk, J. K., Macleod, M. C., Kuroki, T., Drevon, C., Piccoli, C., Montesano, R., Malignant and non-transformed rat liver cell metabolism of benzo(a)pyrene including macromolecular binding and 179 hamster cell mutagenesis. Carcinogenesis 3: 635-639, 1982.

8. Selkirk, J. K., Macleod, M. C., Mansfield, B. K., Nikbakht, A., Metaboifc raticnale for the weak mutagenic and carcinogentc activity of benzo(a)pyrene, in Sugimura, T., Kondo, S., Takebe, H. (eds.): Environmental Mutagens and Carcinogens, $\therefore$ R. Liss, New York, 1982, Pp. 497-504.

9. Selkirk, J. K., Macleod, M. C., Mansfield, B. K., Nikbakht, A., Dearstone, K. C., Species heterogeneity in the metabolic processing of benzo(a)pyrene, in Langenbach, R., Nesnow, S., Rice, J. M. (eds.): Organ and Species Speciftcity in Chemical Carcinogenesis, Plenum Publishing Corporation, New York, 1983, pp. 283-294.

10. Selkirk, J. K., Macleod, M. C., Moore, C. J., Mansfleld, B. K., Nikbakht, A., Dearstone, K., Specles vartance in the metabolic activation of polycycilc hydrocarbons, in Harris, C. C., Cerrut1, P. (eds.): Mechanisms of Chemical Carcinogenesis, A. R. Liss, New York, 1982, pp. 331-349.

11. Selkirk, J. K., Nikbakht, A., Stoner, G. D., Comparative metabolism and macromolecular binding of benzo(a)pyrene in explant cultures of human bladder, skin, jronchus, and esophagus from elght individuals. Cancer Lett. 18: 11-19, 1983. 
12. Tong, S., Selkirk, J. K., Metabolism of 6-nitrobenzo(a)pyrene by hamster embryonic fibroblasts and its interaction with nuclear macromolecules. J. Toxicol. Environ. Health 11: 381-393, 1983.

\section{RADIATION CARCINOGENESIS}
R. L. Ullrich
N. D. Bowles
R. J. M. Fry
M. C. Jernigan
R. D. Ley
C. K. Mckeown
J. B. Storer
L. C. Satterfield
M. Terzaghi
L. L. Triplett

The research efforts of the ionizing radiation carcinogenesis program consist of studies on neutron carcinogenesis, time-dose relationships, the role of host factors in radiation carcinogenesis, and the dynamics of the carcinogenic process after exposure to radiation and chemicals. These problems are being pursued with in vivo studies as well as in vitro and in vivo/in vitro approaches. A common theme among all of these studies is the examination of mechanisms and the establishment of general principles which may allow a better understanding of the risks to humans from radiation exposure. Data from all of these studies are aljo being used to examine more direct methods of extrapolation of animal data to human risks.

The program in ultraviolet radiation arcinogenes is (UVR) is concerned with the following studies: (1) development of model systens, methods and background information that is necessary for designing quantitative UVR carcinogenesis experiments; (11) the role of interactions of UVR and chemicals; and (iii) interactions between lonizing and ultraviolet radiation in skin carcinogenesis.

Neutron Carcinogenesis. The largest effort is directed toward the study of carcinogenesis after exposure to neutrons. The objective of these studies is to define dose response relationships, RBE-dose zelaitonships and dose rate relationshifs for the induction of several mouse tumors. Over the last several years the effects of acute, protracted or fractionated neutron exposures on life shortening and tumor induction have been examined and compared in a series of studies. In these studies particular emphasis has been placed on the study of life shortening, and the induction of lung and mammary adenocarcinomas and ovarian tumors in BALB/C mice.

For life shortening the dose response rose rapidly and then began to plateau at doses in the 25-50 rad dose range. Fractionation with an extended time between fractions ( 30 days) or protraction diminished this plateauing in the 25-50 rad range. This resulted in enhanced life shortening after protraction or fractionation in this dose range. No differences were observed between acute and fractionated protracted exposures at doses in the $0-25$ rad range. As a result fractlonation or protraction resulted in a more nearly linear response over the 0-50 rad dose range. These 
results support a linear dose response for life shortening after neutron exposures at doses below 20 rad.

- Iltional evidence for a linear response for neutrons comes from our recent analysis of data from the studies in our laboratory and from studies at Argonne National Laboratory. This analysis established that the initial slopes of both neutron and gamma dose-response curves for life shortening are linear. Such linearity enforces limiting values of RBEs. The maximum estimated RBEs for life shortening which are sex- and mouse straindependent range from $13-22$.

The induction of lung adenocarcinomas, mammary adenocarcinomas and ovarian tumors in female BALB/c mice was also examined after whole-body nectron irradiation delivered at a high dose rate, in a single exposure, or delivered in two equal fractions separated by intervals of 24 hours or 30 days, and these effects were compared with those after neutron irradiation at low dose rates. The dose-response ior ovarian tumorigenesis after the split-dose fractionation regimen was simllar to that observed after single high dose-rate neutron exposure. However, lowering the dose rate reduced the incidence over the $0-50 \mathrm{rad}$ dose range. For lung and mammary tumors the results were more complex. One observation of particular laterest was that protraction of neutron exposures enhanced the mammary tumorigenic effect of neutrons after doses as low as 2.5 rad. This enhancement at low doses was not observed for lung tumor induction. These data suggest that fractionation and dose-rate effects are different for different tumor types presumably because of the different mechanisms of tumorigenesis that may be involved.

In addition to these studies, the induction of myelogenous leukemia after neution exposures is also being examined. Coupled with a study of the neutron dose response, the possible role of specific chromosome aberrations in myeloid i jukemogenesis after neutron exposures is being examined in collaboration with Drs. Preston and Au (Blology Division). In another coilaborative study Dr. Yang of this Division is examining the possible role of transposition of genetic elements in the development of myelogenous leukemia. Mechanistic studies are also being pursued using an in vivo/in vitro system to study mamary carcinogenesis. This system allows the study of cell killing, transformation and progression of mammary eplthelial cells af ter neutron exposure.

Mammary Carcinogenesis: Development of an Experimental Model. Over the last few years we have been attempting to develop a model to study mamary carcinogenesis which allows the study of the sequence of avents which leads to mammary tumor development after exposure to radiation and chemical carcinogens. This includes the identification and characterization of altered cell populations which emerge, and the identification of factors which influence their progression to neoplasia. The approach taken utilizes a combination of the mamary cell dissociation (CD) system orlginally developed by De0me and his coworkers (Cancer Res. 38: 2103, 1978) and the eptthellal focus assay system developed by Terzaght and Nettesheim (Cancer Res. 39: 4003, 1979). The CD system takes advantage of 
the fact that mammary fat pads of 3-week-old mice, from which the mammary gland rudiments are removed and which therefore contain no mamary cells of their own, serve as an ideal site for the growth and differentiation of mamnary cells from a donor. Further, the injection of enzymatically dissociated cells into gland-free fat pads yields classiflable outgrowths characteristic of the state of the cells. By injecting cells from irradiated mice into these fat pads within 24 hours after irradiation, we have shown that this technique can be used to detect and quantify early alterations in mamiry cells induced by radiation. By allowing cells to remain in situ for various time periods prior to injection, the progression of these aitered cell populations is also being studied.

The epithelial focus assay was originally developed for purposes of identification and isolation of "carcinogen-altered" eptthelial cells from rat tracheas, esophagi, and lungs exposed in vivo to carcinogen. These carcinogen altered cells appear soon af ter the target tissues have been exposed to carcinogen and can be found throughout the tumor latency period. They are considered to be preneoplastic, since compared with unexposed cells, they have an increased likelihood to become neoplastic. These early preneoplastic cells can be identifled because of the acquisition of a markedly increased in vitro growth capacity. Under culture conditions, which are "non-permissive" for most normal tracheal epithelial cells, they not only survive but proliferate rapidly, forming expanding epithellal foci (EF) at a time when the cultures of normal tracheal cells have ceased to proliferate and senescence has set in. Some of the epithelial colonies escape permanently from senescence (or terminal differentiation); they become "1mmortal" and can be propagated in vitro indefinitely. After repeated subculturing, some of the cell line cultures become neoplastically transformed, producing invasive carcinomas upon inoculation fnco compatible hosts. The progenitor-progeny relationship between the colls of the epithelial focus and the malignant cells of the late immortalized cell cultures 1s, if not proven, strongly suggested by previous studies.

The epithellal focus assay (EF-assay) has been modifled for the analysis of the cellular events of neoplastic development in mouse mammary gland. With this assay one can distinguish and quantify three different "growth-phenotypes" of carcinogen altered clonogenic cells: (i) the clonogenic untt giving rise to an epithelial focus (EFo); (11) the clonogenic unit giving rise to an epithelfal focus that permanenty escapes senescence and is subculturable $\left(E F_{8}\right)$; and (111) the clonogenic unit that gives rise to subculturable foct $\left(E F_{s, n}\right)$ that are tumorigenic when injected into the mammary fat pad. In general, we have shown that the first two of these phenotypes of carcinogen altered cells are detectable in carcinogen exposed mamary epithellum lmmediately after carcinogen exposure and that the number of subculturable focus-forming units increases with time even in the absence of any further carcinogenic stimulus. Further, the data suggest differences between the effects of radiation and chemica: carcinogens on this sequence of events. This approach is now being applied to studies of neutron carcinogenesis and time-dose relationships as well as a study designed to compare chemical and radiation nammary carcinogenesis. 
T-me-dose relationships. Berause of the many factors involved in tumorigenesis, interpretation of differences in the effects on tumorigenesis of different rates of exposure may be confounded by their effects on factors influencing tumor expression rather than the induction of initial events. To develop reliable estimates of radiation risk and to determine the general applicability of the principles derived from experimental studies, more information on time-dose relationships for the Induction of solid tumors and the basis for these $r$. itonships is required. Further information on the underlying mechanisms for these timedose relationships is essential. Over the last year we have initiated studies designed to examine time-dose relationships for radiation carcinogenesis. The objectives of this project are to: (i) examine time-dose relationships for the induction of lung adenocarcinomas and mammary adenocarcinomas in $B A L B / C$ mice after gamma ray irradiation, including the influence of dose rate and fractionation; (11) determine whether dnse rate effects are a result of repair or recovery from initial carcinogenic events or due to changes in mechanisms related to tumor expression; and (1ii) examine the persistence of latent carcinogenic effects. For the second and third objectives, experiments are examining early, radiationinduced alterations in growth potential (transformation) of mammary epithelial cells and their progression to neoplasia using the methods discussed above.

Host Factors in Radiation Carcinogonesis. In vitro studies by others have amply demonstrated that radiation causes tra:sformations (presumably malignant) in cultured cells. There is good reason to believe, however, that host Factors in intact animals may be of over-riding importance in determining whether transformed cells progress to a frank mallgnancy. For example, we have shown that relatively minor endocrine manipulations in intact mice markedly affect the incidence of certain radiation-induced tumors. Further, we have shown that many radiation-induced tumors are not Independent and that radtation-induced alterations in host factors sometimes lead to animals dfveloping both tumors (positive association) or one tumor but not the other (negative association). These associations were seen especiall:- In timors of endocrine organs or in tumors believed to be endocrine related.

We are currently conducting studies in two strains of mice which differ significantly in the spontaneous incidence of various tumors to determine whether radiation induction of tumors is related to the spontaneous incidence. If so, we will have further evidence of the major role played by host factors in radiation carcinogenesis. The experiment will also provide evidence for whsther the relative risk or the absolute risk model is appropriate for evaluating carcinogenic risk.

Ultraviolet Radiation Carcinogenesis. ".e studies in this program are designed to study mechanisms of ultraviolet radiation carcinogenes is (UVR) and the interactions of UVR with chemical agents, $X$ rays and psoralen plus UVA (PUVA). 
a. Mechanisms of Carcinogenesis. It has become widely accepted that the induction of pyrimidine dimers is the initiating event in skin cancer caused by exposure to sunlight. However, unequivocal experimental evidence of the causal relationship between the specific type of DNA damage and subsequent skin cancer has not been produced. There are at least two approaches that appear appropriate for investigating the role of pyrimidine dimers. First, the use of an experimental model in which the cells have the capability of photoreactivation. This was the basis of the experiments carried out by Hart, R. W., et al. (Proc. Nat1. Acad. Sc1. USA 74: 5574, 1977) on fish. Second, to determine whether there is a concordance between the action spectrum for UVR-induced skin cancer and the induction of pyrimidine dimers. Both approaches, although relatively sisple in concept, are extremely difficult to carry out experimentally. In the last report we described the Investigations of the action specirum for the induction of pyrimidine dimers in mouse skin that are necessary for the design of the carcinogenesis study and these results have been published. This year we report progress in identifying a sultable animal model system for invest1gating the role of pyrimidine dimers in UVR-induced skin cancer. The animal selected is Monodelphis domestica, a small opossum. We have demonstrated that the cells of this animal are capable of photoreactivating the UVR-Induced DNA damage identified by assay of endonuclease sensitive sites. Evidence of the photoreactive capability in the skin has been obtalned by determining the comparative doses required to induce erythemaedema in opossum skin with and without exposure to photoreactivating wavelengths. It is clear that photoreactivation occurs in the skin of the animals. The tumor studies have begun at Lovelace Institute and are being carried out by $R$. D. Ley.

The induction of overt skin cancer involves a great deal more than fust the inftial events. Skin appears to be very efficlent in suppressing the exprissition of inftiated cells, and we have shown that expression is strain-dependent.

We have used mice with a mutation at the hr locus on different backgrounds to investigate the nature of these genetically determined differences in expression of initiation. We have now compared the susceptibility of hairless SENCAR mice (developed from SKH:hr-l and SENCAR mice) with that of SKi:hr-l mice to both UVR and DMBA induction of skin tumors and with HRS/S/Anl mice to induction by UVR. Following 36 exposures ( $3 /$ week for 12 weeks) to $1000 \mathrm{~J} / \mathrm{m}^{2}(280-400 \mathrm{~nm})$ paptllomatous lesions occurred in $70 \%$ of the: SENCAR:SKH mice ( 7 papillomas/mouse) by 30 weeks, and in $60 \%$ of SKH:hr-1 mice ( 0.7 papllloma/mouse) by 80 weeks, whereas none occurred in HRS/J//N1 mice. In the case of squamous cell carcinomas the cumulative Incidence was not different between SENCAR-SKH and SXH:hr-l but the time of appearance was earlier in the former stock. The latent period (time to $50 \%$ of mice with carcinomas) was about 20 weeks shorter in the SENCAR-SKH. The incidence of carcinomas was $2 \%$ at 70 weeks in the HRS/J/Ani mice. These results suggest that different genetic factors influence the susceptibility to papillomas and carcinomas and also the rate of expression of the tumors. 
In the case of $\mathrm{SKH}: \mathrm{hr}-1$ and HRS/J/Anl, we have ellalnated sove of the potential causes for a difference in the expression of initiation events and now we are concentrating, In collaboration with $E$. Perkins, on the question whether the immune systen plays a role in deteraining susceptibility. Although it is clear that both UVR, and psoralen plus UVA (PUVA), do affect Langerhans cells, and such Indicators of cellular immity as delayed-type hypersensitivity (DTH), there is no direct evidence that such changes play a role in epidermal carcinogenesis.

We have carried out a prelininary study on the action spectrun for effects on DTH. It is thought that Langerhans cells are the target for the UVR effects on the imme systed. It is of some importance to establish whether the target 18 the DNA In the Langerhans cells. Such studies can only be carriea out maningfully if equivalent doses of the different wavelengths are used. We used the assay of diner Induction at the different wavelengths in order to adjust the effective fluences to be equivalent in our study. For exanple, the surface fluence with 289 nn was $667 \mathrm{~J} / \mathrm{m}^{2}$ but $1000 \mathrm{~J} / \mathrm{m}^{2}$ with $302 \mathrm{~mm}$. Both these fluences Induced about $4 \times 10^{5}$ pyrimidine dimers in the basal layer. We found that the longer wavelengths and the broad spectrum 280-400 $\mathrm{nm}$ radiations were more effective than the wavelengths absorbed in DNA. The results suggest a nonDNA target.

b. Cocarcinogenesis. In the study of cocarcinogenesis ( $X$ ray and PUVA) we have found that protracted low dose PUVA treatment enhances the carcinogenic effect of X-irradiation, the carcinogenic effect of the combination of treatments being clearly dependent on the total dose of $X$ rays. This study is also examining effects of TPA and UVR as cocarcinogens relative to PUVA. Since most of the actions of these three agents involve different mechanisms, it provides a way to probe the factors involved in cocarcinogenesis. It may be of importance that all three agents appear to depress delayed-type hypersensitivity.

The Importance of UVR in sunlight as a cause of skin cancer is now undisputed. However, the role of IVR as a cocarcinogen 18 not clearly defined. For example, does exposure to UVR increase the probability of skin cancer in persons exposed to chemicals elther topically or systemically? The question of the Importance of interactions between UVR and the components of the process streams in the production of synthetic fuels and the fina' products is a practical one. We are investigating whether exposure co UVR after exposure to single chemical agents, such as $B(a) P$ or complex mixtures such as shale ofl at dose levels that individually would either produce no tumors or a very low incidence of skin cancer, results in a marked enhancement in tumor expression.

The preliminary results with $B(a) P$ aid UVR indicate a synergistic effect when exposures to UVR follow topical treatment with $b(a) P$. 
1. Adans, L. M., Ethier, S. P., Ullrich, R. L., The survival of mouse manary epithelial cells after in vivo gama ray irradiation. Radiat. Res., subaltted.

2. Ethier, S. P., Ullrich, R. L., Induction of manary tumors in virgin female BALB/C nice by single iow doses of 7,12-diwethylbenz(a)anthracene (IHBA). J. Nat1. Cancer Inst. 69: 1199-1202, 1982.

3. Ethier, S. P., Ullrich, R. L., Factors influencing the expression of ductal dysplasias in mamary outgrowths derived from mono-dispersed mamary epithellal cells. Submitted.

4. Fry, R. J. M. Radiation carcinogenesis: Radioprotectors and photosensitizers, in Nygaard, O. F., SinfC, M. G. (eds.): Radioprotectors and Anticarcinogens, Acadenic Press, New York, 1983, pp. 417-436.

5. Fry, R. J. M., Ley, R. D., The mechanisus of radiation carcinogenesis. Radiat. Phys. Chem., in press.

6. Fry, R. J. M., Nachtwey, D. S., Health effects and radiation in space. Health Phys. Soc. News 1, 11: 3-4, 1983.

7. Fry, R. J. M., Powers-Risius, P., Alpen, E. L., Alnsworth, E. J., Ullrich, R. L., High-LET radiation carcinogenesis. Adv. Space Res. 3: $241-248,1983$.

8. Fry, R. J. M., Storer, J. B., Late effects of radiation: Host factors, In Broerse, J. J., Barendsen, G. W., Kal, H. B., van dei Kogel, A. J. (eds.): Proceedings of the Seventh International Congress of Radiation Research, 1983, 341-348.

9. Fry, R. J. M., Ullrich, R. L., Combined effects of radiation and other agents, in Upton, A. C. (ed.): Radiation Carcinogenes is, Elsevier/ North Holland Blomedical Press, Amsterdam, in press.

10. Hanson, H. R., Crouse, D. A., Pry, R. J. M., Ainsworth, E. J., Murine intestinal and hematopoletic stem celi radiosensitivicy to Peratlab high energy neutrons compared to JANUS neutrons and ${ }^{60}$ Co gamma rays. Radiat. Res., in press.

11. Kle1n-Szanto, A. J. P., Terzagh1, M., Mirk1n, L. D., Mart1n, D., Shiba, M., Propagation of normal human epithelial cell populations using an in vitro cultire system: Description and applications. Am. J. Pathol. 108: 231-239, 1982 .

12. Kohn, K. I., Fry, R. J. M., Radiation carcinogenesis, New Engl. J. Med., in press.

13. Ley, R. D., Immunological detection of two types of cyclobutane pyrimidine dimers in DNA. Cancer Res. 43: 41-45, 1983.

14. Lcy, R. D., Peak, M. J., Lyons, L. L., Induction of pyrimidine dimers in epidermal DNA of halrless mice by UVB: An action spectrum. J. Invest. Dermatol. 80: 188-191, 1983.

15. Nettesheim, P., Terzaght, M., Klein-Szanto, A. J. P., Development and progression of neoplastic disease. Morphologic and cell culture studies with alrway epithelium, in Harris, C. E., Cerutt1, P. A. (ed.): Mechanisms of Chemical Carcinogenesis, A. R. Lis8, New York, 1982, PP. 473-489.

16. Storer, J. B., Associations between tumor types in irradiated BALB/C femsle mice. Radiat. Re8. 92: 396-404, 1982. 
17. Storer, J. B., Carcinogenic effects on humans: Ar overview, in Upton, A. 3. (ed.): Radiation Carcinogenesis, Elsevier/North-hiolland Bionedical Press, Ansterdan, In press.

18. Storer, J. B., Mitchell, T. J., Liditing values for the KBE of fission neutrons at low doses for life shortening in aice. Subsitted.

19. Storer, J. B., Ulirich, R. L., Life shortening in BALB/c mice followIng brief, protractej or fractionated exposures to neutrons. Radiat. Res. 96: 335-347, 1983.

20. Terzaghi, M., Rlein-Szanto, A., Nettesheim, P., Effect of the promoter 1/2-0-tetradecanoyl-13-acetate on the evolution of carcinogenaltered cell populations in tracheas initiated with 7-12-dimethylbenzanthracene. Cancer Res. 43: 1461-1466, 1983.

21. Terzaghi, M., Netteshein, P., Conbined in vivo-in vitro studies of neoplastic development in rat respiratory tissues, in Reznik-Schuller, A. M. (ed.): Comparative Respiratory Tract Carcinogenesis, CRC Press, Boca Raton, FL, 198\%.

22. Terzaghi, M., Netreshe1m, P., Rei०ter, L., Effect of carcinogen dose on the dynaaics of neoplastic development in rat tracheal epithellun. Cancer Res. 42: 4511-4518, 1982.

23. Ullrich, R. L., Lung tumor induction in aice: Neutron RBE at low doses, in Broerse, J. J., Gerber, G. H., (eds.): Proceedings of the European Serinar on Neutron Carcinogenes1s, CEC, Luxemburg, 1982, Pp. 43-55.

34. Ullrich, R. L., Tumor Induction in BALB/c female aice after fission neutron or gemma ray irradiation. Radiat. Res. 93: 506-515, 1983.

25. Ullrich, R. L., Tumor Induction in BALB/c mice after. fractionated or protracted exposures to fission-spectrum neutrons. Radiat. Res., in press.

26. Yott1, L. P., Ley, R. D., Induction of pyrimidine dimers and unscheduled DNA synthesis in cultured wouse epithellal cells exposed to 254-nm and u.v.-B radiation. Carcinogenes18 4: 923-925, 1983.

EFFECTS GF ANDROGENS AND ANTIANDKOGENS ON THE INDUCTION OF MOUSE SKIN PAPILLOMAS BY PHORBOL ESTER TUMOR PROMOTERS

K. A. Davidson

The skin is a target organ for androgenic sterolds. These sterolds stimulate cell proliferation in the epidermis and sebaceous glands. The akin also has the capacizy to convert preandrogens to active androgens and metabolize active androgens to inactive forms that can be excreted. Cyproterone acetate (CPA) is a progestin that has antiandrogenic activity. This agent has been tested clinically in the treatment of abnormal hair growth in hirsute women, acne, prostate cancer and other corfitions associated with abnormal androgen production or the responos of target t1s8ues to andrugens. CPA and other antiandrogens block the stimulator; effects of androgens on cell proliferation in the skin. The antiaridrogenic 
activity of CPA is mediated by its ability to competitively inhibit the binding of androgens to intracellular receptors.

This project was initiated in order co (1) determine if CPA would inhibit the production of papillomas i:duced by the phorbol ester, 12-0tetradecanoylphorbol-13-acetate (TPA), (2) scudy the mechanism by which CPA inhibits the production of papillomas, and (3) study the influence of host factors (androgens) as modulators in the induction of papillomas.

The initiation/promotion protocol was used to inciuce skin papillomas in the highly sensitive SENCAR mouse. 7,12-dimethylbenz(a)anthracene (10 N MOI) was applied to tine dorsal skin (initiation) followed in one week by twice weekly applications of $I$ Hg of TPA for 20 weeks (promotion). CPA was applied simultaneously with $1 \mathrm{\mu g}$ of TPA for the duration of the experiment. A second protocol for inducing papillomas, 2-stage promotion, was also used. TPA $(2 \mathrm{\mu g})$ was applied to the dorsal skin of iritiated mice twice reekly for two weeks (1st stage) followed by twice weekly applications of $2 \mathrm{Hg}$ of mezerein (a nonpromoting hyperplasiogenic agent) for 18 weeks (2nd stage). CPA was applied during the first stage with TPA or during the second stage with mezerein. All agents were applied in $0.2 \mathrm{ml}$ acetone.

The results of these experiments revealed that $500 \mathrm{~g}$ of CPA inhibited the incidence of papillomas/mouse by $95 \%$ and $91 \%$ after 29 and 37 weeks of promotion, respectively. In a second experiment the incidence of papillomas/mouse was inhibited by $84 \%$ (female mice). In male mice $500 \mu$ and $1 \mathrm{mg}$ of CPA inibited tumor promotion by $77 \%$ and $8 \%$, respectively. The androgen, testosterone proplonate (TP) $(500 \mathrm{lg})$, applied simultaneously with TPA and $500 \mu \mathrm{g}$ of CPA partially blocked the inhibitory effect of CPA (female mice) : sgesting that the antiandrogenic activity of CPA is involved in its antipromotion activity. In the 2-stage promotion protocol, CPA Inhibited th- incidence of papillomas/mouse when it was applied during the 2nd stage with mezerein ( $71 \%$ inhibition) but not when it was an siled during the lst stage with TPA.

Phorbol ester tumor promoters induce inflammation (infiltration of leucocytes and edema) in the skin and DNA synthesis, cell proliferation that results in hyperplasia, and increased ornithine decarboxylase activity in the epidermis. 'These paiameters show very good correlation with promotIng activity of phorbol esters. Inflizmmation, epidermal DWA synthesis and hyperplasia were inhibited by a aingle application of $500 \mathrm{~kg}$ of CPA given simultaneously with $2 \mu \mathrm{g}$ of TPA.

These results suggest that CPA may be an effective agent for chemoprevention of chemically induced papillomas and possibly other proliferative lesions in the skin. It is also suggested that androgens have either a direct or indirect influence on the induction of skin papillomas. Two experiments were carrjed out to determine the effect of exogenous androgens on the induction of papillomas by TPA. TP (500 $\mathrm{Hg})$ applied simultaneously with $1 \mathrm{\mu g}$ of TPA Increased the incldence of papillomas/mouse by 2.3-folt and 1.5-fold at 20 weeks and 37 weeks of promotion, respectively. However, 
In a followup experiment, $250 \mathrm{\mu g}, 500 \mathrm{\mu g}$ and $1 \mathrm{mg}$ of TP did not significantly alter the incidence of papillowas/mouse. The discrepancy in the magnitude of the results from the two experiments makes it impossible to form definite conclusions at this time. 


\title{
Educational Activities
}

\section{University of Tennessee-Oak Ridge Graduate School of Biomedical Sciences}

\author{
H. E. BARNETT - DIRECTOR
}

The University of Tennesee-Oak Ridge Graduate School of Bionedical Sciences is located within the Blology Division of Oak Ridge Nationai Laboratory. The progran is primarily designed for training leading to the Ph.D. degree, although there are a few Master's degree candidates. Ph.D. studints are supported by the University of Tennessee in the fora of research assistantships or by federal training grants awarded to the School by the National Cancer Institute and by the National Institutes of Health. The School currently has 42 students working toward the Ph.D. degree and 3 in the Master's progran. As of August 1983, 88 students have been awarded the Ph.D. degree.

The fall quarter of 1983 marks the beginning of the School's eighteenth year. W. Edgar Barnett is the Director. The School also has three full-time faculty memers: Daniel Billen, Donald E. Olins, and Cynthia Soumoff. A major portion of the Schonl's teaching and research training is provided by the staff of the Biology Division who serve as "shared" faculty.

The students form a very active group of investigators in training, and their names appear on a number of mar......'; each year. This repre sents a significant contribution to the productivity and excellence of ORNL's Biology Division. 


\section{Postdoctoral Training Programs}

Postdoctoral training is an important feature of Division activities, providing benefits both to the trainees and to the Division. Support for these training activities is derived from a variety of sources and is adninistered by the University of Tennessee. Two major sources of funds are a subcontract from Union Carbide Corporation and a postdoctoral trainIng grant in Carcinogenesis from the National Cancer Institute. As of July 31, 1983, there were nine trainees enrolled in these postdoctoral prograns.

After a two- or three-year period of research in the Biology Division, trainees have obtained positions in universities, industries, or other government laboratories.

\section{Undergraduate Training Programs}

The Biology Division participatss in three undergraduate training prograns: (1) Great Lakes Colleges Association/Associated Colleges of the Midwest (CLCA/ACM Science Semester), (11) Southern Colleges University Union Science Semester (SCUU), and (1ii) Oak Ridge Associated Universities Sumer Student Trainee (ORAU). Under the auspices of these jrganizations and in cooperation with Oak Ridge National Laboratory, outstanding college juniors are offere: opportunities for independent research in the life sciences. Ten to twenty students who possess the educational qualifications and the potential for a successful scientific career spend 16 weeks (GLCA/ACM and SCUU) or 10 weeks (ORAU) doing research under the guidance of Biology Division staff members.

Although the principal purpose of the programs is to provide a training experience for the students, it of ten allows division staff members an opportunity to broaden their areas of research. Upon completion of their research activities in the laboratory, students prepare a formal scientific paper and present a talk on thetr work. The programs, in which over 500 students have particlpated during the past 20 mars, have recelved the enthusiastic endorsement of the students and the members of the Blology Division. 


\section{Appendices}

\section{Advisory Committee - FY 1984}

Dr. Robert Barker

Dr. Verne M. Chapman

Dr. Henry C. Pitot

Dr. Arthur C. Upton

Dr. Gerald N. Wogan

\author{
Vice President for Research, Cornell \\ University, Ithaca, New York \\ Chairman, Department of Molecular Biology, \\ Roswell Park Memorial Institute, \\ Buffalo, New York \\ Di rector, McArdle Laboratory for Cancer \\ Research, The University of Hisconsin, \\ Madison, Wisconsin \\ Di rector, Institute of Environmental \\ Medicine, New York University Medical \\ Center, New York, New York \\ Head, Department of Nutrition and Food \\ Sciences, Massachusetts Institute of \\ Technology, Cambridge, Maryland
}

\section{Seminar Programs}

INTERNAL SEMINARS AND JOURNAL CLUBS

$\begin{array}{ll}\text { Biochemistry Journal Club } & \text { Semiweekly } \\ \text { Cancer Research Seminar } & \text { Weekly } \\ \text { Plow Cytometry Journal Club } & \text { Biweekly } \\ \text { Genetics Seminar } & \text { Weekly } \\ \text { Histopathology Slide Seminar } & \text { Weekly } \\ \text { Staff Seminar } & \text { Weekly }\end{array}$


The following seminars were given in the Blology Division by scientists from research organizatiust In the United States and abroad during the period August 1, 1982 through Sep':ember $30,1983$.

\begin{tabular}{|c|c|c|}
\hline Speaker & Affiliation & Suvject \\
\hline Anderson, Norman & $\begin{array}{l}\text { Argonne National Laboratory } \\
\text { Argonne, Illinols }\end{array}$ & Human proteln Index. \\
\hline Bachhawat, B. K. ${ }^{\text {a }}$ & $\begin{array}{l}\text { Indian Institute of } \\
\text { Chemical Biology } \\
\text { Calcutta, India }\end{array}$ & $\begin{array}{l}\text { Use of liposomes in drug delivery and } \\
\text { Immunology }\end{array}$ \\
\hline Bant le, Jack & $\begin{array}{l}\text { Oklahoma State University } \\
\text { St1llwater, Oklahoma }\end{array}$ & $\begin{array}{l}\text { The use of Xenopus oocytes as a gene toxicity } \\
\text { and expression assay }\end{array}$ \\
\hline Brodie, Arnold ${ }^{a}$ & $\begin{array}{l}\text { Nailonal Institute of } \\
\text { Lnvironmental Health } \\
\text { Sciences } \\
\text { Research Triangle Park, } \\
\text { North Carolina }\end{array}$ & $\begin{array}{l}\text { Inttlal pathogenesis of asbestos-induced } \\
\text { lung disease }\end{array}$ \\
\hline Chirgwin, John & $\begin{array}{l}\text { Washington Medical School } \\
\text { St. Louls, Missouri }\end{array}$ & $\begin{array}{l}\text { Molecular genetics of insulin and renin in } \\
\text { man and mouse }\end{array}$ \\
\hline Collins, Andrew & $\begin{array}{l}\text { University of Cambridge } \\
\text { Cambridge, England }\end{array}$ & Inhibition of DNA repair - why bother? \\
\hline Crespi, C. L. & $\begin{array}{l}\text { Massachusetts Institute of } \\
\text { Technology } \\
\text { Cambridge, Massachusetts }\end{array}$ & Human lymphoblasts that metabolize mutagens \\
\hline
\end{tabular}


Doyle, Darrell

DuFrain, R. J. b

Farkas, W. R. ${ }^{\text {a }}$

Fuscoe, James C. ${ }^{b}$

Gratzner, Howard ${ }^{c}$

Hosokawa, K.

Lehruch, $H$.

Levine, Arnold ${ }^{a}$

Lewis, Susan E. ${ }^{b}$
Roswell Park Memorial Institute

Buffalo, New York

Oak Ridge Associated Universities

Oak Ridge, Tennessee

University of Tennessee

Memorlal Research Center Knoxville, Tennessee

Baylor College of Medicine Houston, Texas

University of Miami School of Medicine Miami, Florida

Kawasak1 Medical School

Kurashik1, Japan

European Molecular B1ology Laborat ory

Heidelberg, Germany

State UnIversity of New York at Stony Brook Stony Brook, New York

Research Triangle Institute Research 'Trfangle Park, North Carulina
Metabolism of plasma membrane proteins in hepatocytes

Cytogentc analysis of somatic and female germ cell damage in neonatal rabb1ts: A preliminary report

Role of diets in the synthesis of $Q$ family trangfer RNAs

Deletion and amplification events at the hgprt locus in Chinese hamster cells

DNA replication and cell $\mathrm{kinetics}$ by Immunofluorescence techniques

Structure and function of adenovirus chromatin

Cloning of gene reglons contalning developmental mutations: The $\mathrm{T}-\mathrm{t}$ complex in the mouse

Regulation of cellular gene expression in transformed cells

Electrophoretically detected specitic locus mutations in intce 
Lieber, H. L.

Massachusetts Institute of Technology

Cambridge, Massachusetts

Lindenschmidt, R. C.

Maio, Joseph J.

Morgan, $\mathrm{K}$.

Moseley, E. B. ${ }^{a}$

Natarajan, A. T.

Nicholas, Rcoert ${ }^{d}$

Pincheira, Guido

Plaa, G. L.
Indiana University

Indianapolis, Indiana

Albert Einstein College of Medicine

New York, New York

Chemlcal Ir.dustry Institute of Toxicology

Research Triangle Park, North Carolina

\section{University of Edinburgh} Scotland

University of Leiden

The Netherlands

University of California at San Diego San Diego, California

University of Chile Sent 1ago, Chile

Faculty of Medicine University of Montreal

Montreal, Quebec, Canada
Mutagenicity of 1-2-5 lododeoxyuridine and tritiated thymidine in human lymphoblasts

Paraquat-1nduced pulmonary edema in the perfused lung

Kpn families, interspersed DNA's and human gene organization

The nose: Structure, function and toxicity, with special reference to formaldehyde and the mucocillary apparatus

DNA repalr in micrococcus

Relationship between sister chromatid exchanges, chromosome aberrations and point mutations

Purteication of membrane-spanning peptides from Na/K-ATPase

The current status of basic research in Chile

Chemical interaction in the potentiation of toxic liver damage 
Plewa, M. J.

Revis, N. W. ${ }^{a}$

Schleich, Thomas

Skow, L. C. ${ }^{b}$

Thilly, W, G.

Tyrre11, R. M.
Institute for Environmental Studies

University of Illinols

Urbana, Illinols

Oak RIdge Research Institut: Oak Ridge, Tennessee

University of California

Santa Cruz, Callfornia

Nat Ional Institute of Environmental Health Sclences

Research Triangle Park, North Carolina Technology

Cambridge, Massachusetts

Swiss Institute of Experimental Cancer Research

Lausanne, Switzerland
Massachusetts Inst1tute of
The activation of promutagens by plant cells in culture

The relationship of $\mathrm{Pb}, \mathrm{Cd}$ and $\mathrm{Cl}$ to the inductinn of hypertension aud atheroslcerosis

Blochemistry as studied by proton MMR spectroscopy: A survey of recent results with specific application to damage in whole tissue including the intact eye

A mouse model of human beta thalassemia

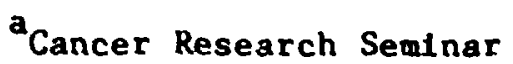

${ }^{b}$ Genetics Seminar

cGenetics and Developmental Blology Seminar Series

d Blochemlstry Journal Club
}

Repalr of ultraviolet radiation damage in cultured human cells 


\section{Research Conferences}

A Workshop un Neutron Radiation Carcinogenes1s, sponsored by the nffice of Health and Environmental Research of the U.S. Department of Energy and the Low-Level Radiation Effects Branch of the National Cancer Institute, and hosted by the Blology Division, was held at Tie Oak Ridge Associated Universities conference center on September 19-20, 1983. The Workshop was actended by research workers from Europe and the United States, as well as zepresentatives of many government agencies. This Workshop was an activity of the newly formed External Radiation rarcinogenesis Interlaboratory Group.

A round table discussion on "In vitro Radiation Transformation" was

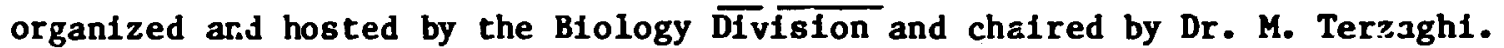
The discussion took place on Scptember 21, 1963, and was attended by radiobiologists frow across the country.

The first Regional Flow Cytometry User's Meeting took place on September 23, 1983 under the sponsorship of the Blology Division. The chairman of the organizing committee was Dr. Reintold Manr of the Blology Division. The meeting was held at the conference center of the Oak Ridge Associated Universities.

\section{Extramural Activities}

1. Officer of Society
D. Billen
- Executive Committee, Radiation Research Society, 1979-present
J. L. Epler
- Councilor, Environmental Mutagen Soclety, 1979-1983
S. Lock
- Secretary-Treasurer, Southeastern Reglonal Chapter of the Society of Toxicology, 1983-1985
P. Mazur
- Board of Governors, Society for Cryoblology, 1981-1985
A. L. $011 \mathrm{~ns}$
- Councilor, American Society for Cell Blology, $1984-1986$ 
R. J. Preston

K. O. Rahn

L. B. Russell

D. M. Skinner

z. Sociaty Committees

H. I. Adler

D. Billen

J. S. Cook

J. L. Epler

R. J. M. Fry

W. M. Generoso

F. C. Hartman
- Councilor, Environmental Mutagen Society, 1983-present

- Councilor, American Society for Photobiology, 1980-1983

- President-Elect, Environmental Mutagen Soclety, 1983-1984

- Chairperson-Elect, Section G, Biological Sciences, American Association for the Advancement of Science, 1983

- Education and Training Committee, Radiation Research Society, 1980-1984

- Finance Committee, Radiation Research Society, 1979-present

- USA National Committee for the International Union of Physiological Sciences (Vice Chairman), 1977-1982

Publications Committee, Society of General Physiologists, 1982-1986

Publications Committee, Federation of American Societies for Experimental Biology, 1982-1985

Membrane Biophysics Subgroup (Chairman), Biophysical Society, 1984

- Membership Comnittee (Chairman), Environmental Mutagen Scciety, 1982-1983

- Awards Monitoring Committee (Chairman), Rad1ation Research Society, 1982-present

History Comittee, Radiation Research Soctety, 1982-present

- Committee on Workshops and Training, Environmental Mutagen Society, 1982-present

- Nominating Committee, American Society of Blological Chemists, 1982

Nominating Committee, American Chemical Soclety, Division of Biological Chemistry, 1982 
P. Mazur

A. L. Olins

R. J. Preston

L. B. Russe11

D. II. Skinner
- Publications Committee (Chairman), Society for Cryobiology, 1974-present

- Constitution and By-laws Committee, American Society for Cell Biology, 1982-present

- Awards and Honors Committee, Environmental Mutagen Society, 1983-present

- Publications Policy Comittee, Environmental Mutagen Society, 1981-1982

Program Committee (Chairman), Environmental Mutagen Society, 1983-1984

- Committee on Equal Opportunities for Women, American Society of Biological Chemists, 1980-1983

Public Policy Committee, American Society for Cell Biology, 1981-present

\section{Advisory Comnittees}

D. Billen

J. S. Cook

R. J. M. Fry
- Research Manpower Training Committee (ad hoc member), National Cancer Institute, 1980-present

- Special Study Section, National Institutes of Health, 1981, 1982 (Chairman)

Member of the Corporation, Mount Desert Island Blological Laboratory

Advisory Board to Current Top cs in Membranes and Transport, $1 \overline{983}$

- Scientific Committee 40, National Council on Radiation Protection and Measurements, 1977-present

Council Member, National Council on Radiation Protection and Measurements, 1980-present

Advisory Committee, Radiation Effects Research Foundation, National Academy of Sciences, 1980-present

Program Advisory Committee (Chairman), Lawrence Berkeley Laboratory, 1980-present

Scientific Comittee 75 (Chal rman), National Council on Radiation Protection and Measurements, 1983- 
Advisory Committee, Radiological Research Accelerator Facility, Columbia University, 1983

Oversight Committee for Radioepidemiological

Tables, National Academy of Sciences, 1983-

W. M. Generoso

R. A. Griesemer

A. W. Hsie

S. J. Kennel

F. T. Kenney

A. L. Olins

D. E. $011 \mathrm{~ns}$
- Panel on Cholinesterase Reactivators, Comintee on Toxicology, National Research Counc11, 1982-present

- Pesticide Information Review and Evaluation Committee, National Research Council, 1981-presest

Subcomittee to Evaluate Effects of Short-Term Exposures to Drinking Water Contaminants, Committee on Toxicology, National Research Council, 1982-present

Coumittee on Toxicology, National Research Council: 1983-1986

Panel on Chemical Carcinogenesis Testing and Evaluation, National Toxicology Program, 1982-present

Third Task Force for Research Planning for the National Institute for Environmental Health Sciences, 1983-1985

Working Group on Shale 0ils, Soots, Creosote, Coal Tars and Pitches, and Asphalt, International Agency for Research on Cancer, Lyon, 1983

- Member of Scientific Directorate, Coordinating Council for Cancer Research, Villejuif, France, 1978-present

- Study Section on Health Ef fects Research, Environmental Protection Agency, 1982-present

- Advisory Comittee for Personnel in Research, American Cancer Society, 1978-present

- Member of the Corporation, Woods Hole Marine Biological Laboratory, 1983-

Gordon Conference on Chromatin, 1984, 1986 (Co-chal rman)

- Research Council, University of Tennessee, 1981-present

Molecular Biology Study Section (ad hoc member), National Institutes of Health, 1983 
Menber of the Corporation, Wosds Hole Marine Biological Laboratory, 1983-

Associate, Helicon Foundation, LaJolla, Callfornia, 1983-

Faculty Senate, Untiversity of Tennessee, 1983-1986

Gordon Conference on Chromatin, 1984, 1986 (Co-chairman)

R. J. Preston

L. B. Russell

W. L. Russell

G. A. Sega

J. K. Selkirk
- Cytogenetic Adviser to Ethylene Oxfde Council and to Health Industry Manufacturers Association, 1981-present

Health Effects Adviser to Clinch River Breeder Reactor Project, 1981-1983

Genetics Working Group, American Natjonal Standards Institute, 1983-

- Comittee I, International Comission for Protection Against Environmental Mutagens and Carcinogens, 1977-present

International Comittee on Standardized Genetic Nomenclature for Mice, 1977-present

Coordinating Comittee of Gene-Tox Task, Environmental Protection Agency, 1980-present

Committee on Risk Assessment of Gene-Tox Task (Chairman), Environmental Protection Agency, 1980-present

Sclence Advisory Panel, Litton Bionetics, 1980-present

Board on Toxicology and Environmental Health Hazards, National Academy of Sciences, 1981-1984

Distinguished Scientist Comnittee, University of Tennessee-0ak RIdge National Laboratory, 1983-

- Scientific Adviser to U.S. Delegation, United Nations Sclentific Committee on the Effects of Atomic Radiation

- Site Visit Review Committee, National Institutes of Health, Environmental Health Services Center Grant, 1983

- Breast Cancer Task Force, National Institutes of Health, 1979-1982

Commttcee on Pyrene and Analogs, National Acarlemy of Sclences, 1981-1982

Blochemistry Study Section, American Cancer Society, 1983-1988 
D. M. Skinner

J. B. Storer

M. Terzaghi

R. L. Ullrich

H. R. Witschi
- Member of the Corporation, Barine Biological Laboratory, Woods Hole, 19?1-present Pec- Review Committee, Visiting Professorships fr.r Women, National Science Foundation, 1983-

- Scientific Committee 1 on Bas tc Radiation Protection Criteria, National Council on Radiation Protection and Messurements, 1975-

Council Member, National Coulcil on Radiation Protection and Meastrements, 1969-

- Clinical Pathology Study Section, National Institutes of Health, 1982-present

- Scientific Committee 40 on the Biological Aspects of Radiation Protection Criteria, National Council on Radiation Protection and Measurements, 1977-present

- Scientific Review Panel for Health Research, office of Research and Development, Environmental Protection Agency, 1980-present

Toxicology Study Section, National Institutes of Health, 1980-1984

Comittee for the Characterization of the Status of Toxicity Data Elements for a Select Universe of Compounds, National Research Counc11, 1980-1983

Safe Drinking Water Committee, National Research Council, 1981-1982

Review Committee (Chairman), Inhalation Toxicology Division, Health Effects Research Laboratory, Environmental Protection Agency, 1982-present

Ozone Program Project Committee, Primate Center, University of California-Davis, 1983

4. Editorial Boards
H. I. Adler
D. Billen

- Radiation Research (Associate Editor),

$$
\text { 1980-1987 }
$$

- Radiation Research (Editor-in-Chief), 1979-present 
J. S. Cook

J. L. Epler

H. M. Generoso

F. C. Hartman

A. W. Hsie

P. Mazur

A. L. O11ns

D. E. O11ns

R. J. Preston

J. D. Regan

L. B. Russe11

J. S. Selkirk

D. M. Skinner

R. L. U11rich
- American Jcurnal of Physiology, 1981-present Cell and Generas Physiology, American Phystological Society Handbook Series, 1982-1984

- Mutation Research, 1977-1983

Envi ronmental Mutagen Society Newsletter, $1980-1983$

- Teratogenesis, Cárcinogenesis, and Mutagenesis, 1979-present

- BioScience, 1980-1980 Journal of Protein Chemistry, 1982-1987 Journal of Blological Chemistry, 1983-1988

- Mutation Research, 1976-1982 Fundamental and Applied Toxicology, 1983Teratogenesis, Carcinogenesis, and Mutagenesis, 1983-

- Cryobiology, 1967-present Cryo-Letters, 1979-1982

Revue Francaise de Transfusion et Immunohématologie, 1979-present

- European Journal of Cell Blology, 1982-1986 Molecular and Cellular Blochemistry, 1982-1985

- Molecular and Cellular Blochemistry, 1982

- Environmental and Experimental Botany, 1979-present Mutation Research Letters (Managing Editor), 1980-present

Teratogenesis, Carcinogenesis, and Mutagenesis, 1980-present

- Cell Blology and Toxicology, 1983-

- Mutation Research, 1976-present Environmental Mutagenes18, 1978-1983

- Cancer Research, 1982-1985 Carcinogenes18, 1980-present

- Growth, 1979-1986 B1ological Bullet1n, 1981-1984

- Radlation Research, 1983-1986 
H. R. Hitschi

- Toxicology and Applied Pharmacology, 1978-present

Toxicology, 1978-present

Environmenta] Health Perspectives, 1981-prescut

5. Awards

S. Mitra

A. L. Olins

L. B. Russell

J. B. Storer

H. R. Witschi
- NSF U.S./India Scientists Exchange Fellowship, 1982

- Nafto Foundation of Japan Award, 1982

- Corporate Research Fellow, Union Carbide Corporation, 1983

- Distinguished Service Award, The University of Chicago, 1983

- Corporate Research Fellow, Union Carbide Corporation, 1983

- Diplomate, Board of Toxicological Science, 1982 
ABSTRACTS POR TECHNICAL MEETINGS HELD

AUGUST 1, 1982 - SEPTEMBER 30, 1983

Aardesa, M. J., W. H. All, and R. J. Preston. A comparison of the sensitivity to $X$-ray induced chromosome aberrations in meloid leukena cells and norwal bone marrow cells. Environnental Mutagen Society, San Antonio, Texas, Macch 3-6, 1983.

Adler, Howard I., and Weldon D. Crow. An unusual method for producing anaerobic conditions. 3lst Annual Heeting, Radiation Research Society, San Antonio, Texas, February 27-Harch 3, 1983.

Allon, R. L., and D. E. Olins. Exanination of chromatin replication in the ciliated protozoa (hypotricha) with silver staining and thiolspecific coumaria maleimide. American Scciety for Cell Biology, Baltimore, Maryland, November 30-December 4, 1982.

Amsler, K., and J. S. Cook. Developient of $\mathrm{Ha}^{+}$-dependent phlorizin binding sites in a clone of LLC-PK 1 cells. American Society for Cell Biology, Baltimore, Maryland, November 30-December 4, 1982.

Au, William W., Henry E. Luippold, J. Patrick O'Nelll, and R. Julian Preston. Neocarzinostatin induces chromosome aberrations and mutation but not sister chromatid exchanges in CHO cells. Environmental Mutagen Society, San Antonio, Texas, March 3-6, 1983.

Bhattacharyya, A., B. C. Pal, and S. Mitra. Synthesis of radio-labelled $0^{4}$-ethylthymidine 5'-triphosphate: A novel approach to study the repair of $0^{4}$-alkylthymidine. American Chemical Society, Washington, D.C., August 29-September 2, 1983.

Bonnewe11, V., R. F. Fowler, and D. M. Skinner. Sequence augmentation by amplification of an $(A+T)-r i c h 142$ bp segment in a $(G+C)-r i c h$ satellite DNA. American Society for Cell 3iology, Baltimore, Maryland, November 30-December 4, 1982.

Boone, L. R., C. -Y. Ou, F. E. Myer, D.-M. Yang, R. H. Tennant, and W. K. Yang. Analysis of the Fv-l gene target in N-tropic and B-tropic MuLV by restriction fragment exchange and nucleotide sequence analysis. Cold Spring Harbor Symposium, Cold Spring Harbor, New York, May 25-29, 1983.

Boone, L. R., W. K. Yang, and R. W. Tennant. Pine Structure Analysis of Retroviral LTRs: Implications for Induced Gene Transpositions in Mammalian Cells. New Building Dedication, NIEHS, Research Triangle Park, North Carolina, November 15, 1982. 
Bunick, G. J., E. C. Uberbaciner, and D. E. 0lins. Neutron scattering and $X$-ray diffraction of nucleosomes and nucleosome - HMG complexes. American Society for Cell Biology, Baltimore, Maryland, November 30Decenber 4, 1982.

Carrier, Hillan L., Willian H. Lee, and Janes D. Regan. Studies on ultraviolet light induction and excision repair of pyrinidine diners in human skin fibroblasts. International Congress of Radiation-Research, Ansterdan, The Netherlands, July 3-8, 1983.

Carrier, Y. L., and J. D. Regan. Studies on JV-light induction and excision of pyrinidine dimers in the DNA of mamalian cells. Envi ronmental Mutagen Soclety. San Artonio, Texas, March 3-6, 1983.

Castejlani, Amleto, Hilliam L. Carrier, and James D. Regan. The eirect of hydroxyurea (HU) on excision repair of ultraviolet light induced pyrimidine dimers in proliferating and quiescent human fibroblasts. International Congress of Radiation Research, Amsterdam, The Netherlands, July 3-8, 1983.

Dekarini, D. M., T. K. Rao, J. L. Epler, and A. W. Hsie. Mutagenicity of crude and neutral fractions of liquified coal oils in the Salmonella and CHO/HGPRT assays. Environmental Mutagen Society, San Antonio, Texas, March 3-6, 1983.

Dodson, L. A., R. S. Foote, S. Mitra, and W. E. Masker. Mutagenes 1s of bacteriophage T7. UCLA Symposia, Keystone, Colorado, Apri1 10-15, 1983.

Dodson, Lor1 A., and Warren E. Masker. In vivo and In vitro mutagenesis of bacterlophage T7. American Soclety for Microbiology, Nashville, Tennessee, November 5-6, 1982 .

Donnelly, Mark I., Fred C. Hartman, and V. R. Ramakrishnan. Activation of ribulosebisphosphate carboxylase/oxygenase from Rhodospirillum rubrum occurs without large conformational changes. American Society of Blological Chemist8, San Francisco, California, June 5-9, 1983.

Donnelly, Mark I., V. R. Ramakrishnan, and Fred C. Hartman. Chemical and physical characterization of the $\mathrm{CO}_{2} / \mathrm{Mg}^{2+}$-induced activation of ribulosebisphosphate carboxylase/oxygenase from Rhodospirillum rubrum. Sixth International Congress on Photosynthesis, Vrije Universiteit Brussel, Brussels, Belgium, August 1-6, 1983.

Donnelly, M. I., C. D. Stringer, and F. C. Hartman. Characterization of the activator site of Rhodospirillum rubrum ribulosebisphosphate carboxylase/oxygenase. American Chemical Society, Washington, D.C., August 28-September 2, 1983. 
Dumont, J. H., J. L. Epler, and T. W. Schultz. Mutagenic, embryotoxic and teratogenic effects of complex mixtures of synfuel materials. Environmental Mutagen Society, San Antonio, Texas, March 3-6, 1983.

Dumont, J. N., T. W. Schultz, and R. G. Epler. The response of the FETAX model to ammalian teratogens. Teratology Society, Atlantic City, New Jersey, June 26-29, 1983.

Epler, J. L. Cancer in the workplace: chemical industries - petroleun. International Conference on "Cancer in the Workplace," Vancouver, British Columbia, Canada, May 16-18, 1983.

Epler, J. L. Identification of hazardous conponents within complex energy effluents and products. Third International Congress on Toxicology, San Diego, California, August 28-September 3, 1983.

Ethier, S. P., and R. L. Ullrich. Factors Influencing expression of mammary ductal dysplasia in BALB/C mice. American Association for Cancer Research, San Diego, California, May 25-28, 1983.

Fishman, J. B., and J. S. Cook. Hetcrogeneous recycling of surface sialoglycoproteins in HeLa cells. American Society for Cell Blology, Baltimore, Maryland, November 30-December 4, 1982.

Foote, Robert S., Abraham W. Hsie, Bimal C. Pal, and Sankar Mitra. $0^{6}$-Methylguanine-DNA methyltransferase in mammalfan cells. UCLA Symposia, Keystone, Colorado, April 10-15, 1983.

Fowler, R. F., V. Bonnewell, and D. M. Skinner. Unusual sequence features in the repeat unft of a $(G+C)-r i c h$ crab satellite DNA. American Society for Ce:l Blology, Baltimore, Maryland, November 30-December 4, 1982.

Franc18, Andrew A., and James D. Regan. Photosensitivity of human DNA following UV Irradiation. Environmental Mutagen Soctety, San Antonio, Texas, March 3-6, 1983.

Fry, R. J. M., and D. S. Nachtwey. Health effects of the radiation environment in space. Radiation Research Society, San Antonio, Texas, February 27-March 3, 1983.

Fry, R. J. M., and J. B. Storer. Late effects of radiation: Host factors. International Congress of Radiation Research, Amsterdam, The Netherlands, July 3-8, 1983.

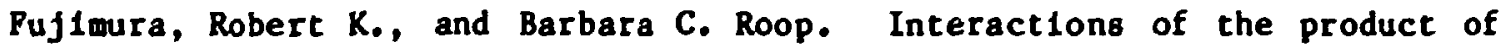
gene DS of bacterfophage TS with DNA and DNA polymerase. American Society of Blological Chemists, San Prancisco, Callfornia, June 5-9, 1983. 
Fujlmura, Robert K., and Barbara C. Roop. Mechanism of Inhibition of DNA synthesis in vitro by a double-stranded DNA binding protein induced by bacteriophage TS. UCLA Symposium, Keystone, Colorado, April 3-9, 1983.

Glover, P. L., and E. H. Perkiıs. Antigen-induced proliferation of thioglycolate-elicited mouse peritoneal macrophages in vitro under normal cultural conditions. 19th National Reticuloendothelial Socfety, St. Louis, Missouri, October 16-20, 1982.

Hear 1, W. G., D. Dorsett, and K. B. Jacobson. Synthesis of the common precursor of sepiapterin and drosopterins in Drosophila. 7th International Symposia on Pteridines and Folic Acid Derivatives, Cherical, Biological and Clinical Aspects, St. Andrews, Scotland, September 21-24, 1982.

Heartlein, M. W., and R. J. Preston. An explanation of interspecific differences in sensitivity to $X$-ray-induced chromosome aberrations. Environmental Mutagen Society, San Antonio, Texas, March 3-6, 1983.

Heckman . C. A., S. E. Ludemann, A. E. Campbe11, and Y. B. Shah. Cell shape changes in oncogenic transformation. American Society for Cell Biology, Baltimore, Maryland, November 30-December 4, 1982.

Hellwig, R. J., S. N. Sinha, and S. K. Niyogi. Specific transcription of ordered nucleoprotein complexes containing the adenovirus 2 major late promoter by RNA polymerase II in a HeLa cell-free system. American Society of Biological Chemists, San Francisco, California, June 5-9, 1983.

Herndon, Cinda S., and Fred C. Hartman. Affinity labeling of an activesite histidyl residue in ribulcsebisphosphate (RuBP) carboxylase/ oxygenase. American Society of Blological Chemists, San Francisco, California, June 5-9, 1983.

Hitotsumach1, S., D. A. Carpenter, and W. L. Russell. Dose fractionation as a means of increasing the mutagenic effectiveness of ethylnitrosourea in mouse spermatogonia. Environmental Mutagen Society, San Antonio, Texas, March 3-6, 1983.

Hotchkiss, J. A., and S. J. Kennel. Monoclonal antibodles to normal mouse lung. Second Annual Congress for Hybridoma Research, Philadelphia, Pennsylvania, February 6 10, 1983.

Hsie, A. W. Quantitative analysis of mammalian cell mutagenesis. 13th Annual Meeting, European Environmental Mutagen Society, Montpillier, France, September 5-9, 1983.

Isham, Kenneth R., Robin Rothrock, Kai-Lin Lee, and Francis T. Kenney. Transcriptional and translational control in development of tyrosine aminotransferase. American Society of Biological Chemists, San Francisco, California, June 5-9, 1983. 
Jacobson, K. I., E. H. Lee, J. M. Flanagan, D. R. Hare, and Brian R. Reed. $\mathrm{Zn}^{2+}$ causes unique alterations of tRNA conformation. American Society of Biological Chemists, San Francisco, California, June 5-9, 1983.

Jacobson, K. B., E. H. Lee, J. M. Flanagan, B. R. Reid, and D. R. Hare. Alteration of tRNA conformation by zinc ions. tRNA Workshop, Hakone, Japan, March 22-25, 1983.

Jacobson, K. B., J. J. Yim, and C. R. Wobbe. Enzymatic localization of the site of action of a suppressor mutant that restores the biosyuthesis of drosopterins in the purple mutant of Drosophila melanogaster. 7th International Symposium on Pteridines and Folic Acid Derivatives, Chemical, Biological and Cilnical Aspects, St. Andrews, Scotland, September 21-24, 1982.

Jamasbi, Roudabeh J., and Eugene H. Perkins. Production of vaccine to DEN-induced carcinomas by in vitro attenuation. American Association for Cancer Research, San Diego, California, May 25-28, 1983.

Kao, J., J. W. Hall, and J. M. Holland. A method for in vitro cutaneous toxicity evaluation. Joint meeting of the American Society for Pharmacology and Experimental Therapeutics, and the Society of Toxicology, Louisville, Kentucky, August 15-19, 1982.

Kao, J., L. R. Shugart, and J. M. Holland. An in vitro approach to studying cutaneous metabolism and disposition of topically applied xenoblotics. 3rd International Congress on Toxicology, San Diego, Callfornia, August 28-September 3, 1983.

Kennel, S. J., and P. K. Lankford. Two site double monoclonal antibody assay for fragment $D$ of human fibrinogen. Second Annual Congress for Hybridoma Research, Philadelphia, Pennsylvania, February 6-10, 1983.

Lalley, P. A., and J. M. Chirgwin. Mapping of mouse insulin genes. VIIth International Workshop on Human Gene Mapping, Los Angeles, California, August 21-27, 1983.

Lalley, P. A., and J. A. Diaz. Comparative gene mapping in the mouse Involving genes assigned to human chromosomes 7 and 20 . VIIth InternatIonal Workshop on Human Gene Mapping, Los Angeles, Callfornia, August 21-27, 1983.

Lalley, P. A., J. A. Diaz, A. A. Prancis, W. C. Dunn, W. L. Carrier, and J. D. Regan. The expression and chromosomal assignments of genes required for repair of UV-induced DNA damage. VIIth International Workshop on Human Gene Mapping, Los Angeles, California, August 21-27, 1983. 
Lalley, Peter A., J. A. Dhaz, A. A. Francis, H. C. Dunn, W. L. Carrjer, and James D. Regan. DNA repair: genetic dissection and chromosomal location of the genes zequired for ultraviolet radiation induced DNA damage in man usirg human $X$ mouse somatic cell hybrids. International Congress of Radiation Research, Amsterdan, The Netherlands, July 3-8, 1983.

Lalley, P. A., J. A. Diaz, A. A. Francis, W. C. Dunn, and J. D. Regan. Genetic analysis of repair of UV-induced DNA damage in man using somatic cell hybrids. Environmental Mutagen Society. San Antonio, Texas, March 3-6, 1983.

Lalley, P. A., J. A. Diaz, A. A. Francis, H. C. Dunn, and J. D. Regan. The expression and chromosomal assignments of genes required for repair of UV-induced DNA damage in man. Radiation Research Society, San Anton:0, Texas, February 27-March 3, 1983.

Larimer, F. W., A. A. Hardigree, M. F Characterization of $\mathrm{N}$-methy $\mathrm{I}-\mathrm{N}$-nitrosourea mutagenesis in Saccharonyces cerevisiae: allele-specificity and repail dependence. Environmental Mutagen Society, San Antonio, Texas, March 3-6, 1983.

Laughlin, T. J., R. L. Allen, A. P. Butler, A. L. Herrmann, C. L. Cadilla, and D. E. Olins. The chromatin organization of the active and inactive genes of the binucleated eukaryote Oxytricha. Symposium in Molecular Biology, University Park, Pennsylvania, July 27-29, 1983.

Laughlin, T. J., J. M. Henry, A. P. Butler, and D. E. Olins. The structure of gene-sized chromatin fragments from the macronucleus of Oxytricha nova. American Society for Cell Blology, Baltimore, Maryland, November 30-December 4, 1982.

Lew1s, Susan E., F. M. Johnson, L. C. Skow, Lols B. Barnett, and R. A. Popp. $A$ mutation in the $\mathrm{Hbb}^{8}$ geile induced in a female by ethylnitrosourea. Twelfth Biochemical Genetics Workshop, Bar Harbor, Maine, August 29September 2, 1983.

I.ewis, S. E., R. A. Popp, F. M. Johnson, and L. C. Skow. A spontaneously arisen $\beta$-thalassemia mutant in mice. Environmental Mutagen Society, San Antonio, Texas, March 3-6, 1983.

Ley, R. D., and R. J. M. Fry. Ultraviolet radiation-1nduced changes in the optical properties of halrless, albino mouse epidermis. International Congress of Radiation Research, Amsterdam. The Netherlands, July 3-8, 1983.

Machanoff, Richard. Enzyme degradation as a factor in phenotypic expression. UCLA Symposia, Keystone, Colorado, March 26-April 1, 1983. 
Mann, R. C., G. R. Braslawsky, and R. E. Hand, Jr. Statistical analysis of DNA histograms measured in flow systems. Combined International Conference on Analytical Cytology IX, Schloss Elmau, Mittenwald Bavaria, Federal Republic of Germany, October 17-23, 1982.

Marchok, A. C., S. F. Huang, and D. H. Martin. Growth dynamics and progression of neoplasia in presumptive neoplastic cell populations (PNCP) from rat tracheas exposed to dimethylbenz[a]anthracene (DMBA). American Association for Cancer Research, San Diego, California, May 25-28, 1983.

Mazur, Peter. Fundamentals of the freezirg of organs and cel1s: simflarities and differences. Symposium oti the Cryopreservation of Organs, Society for Cryobiology, Carbridge, England, August 30September 2, 1983.

Mazur, Peter. Responses of living cells to the events occurring during freezing and thawing. American Association for the Advancement of Sclence Symposium on "The Preservation of Germplasm," Detroit, Michigan, May 29, 1983.

McKinley, Marcus D., and Bimal C. Pal. Environmental pollutant 5-chlorouracil is incorporated in mouse liver RNA. American Chemical Society, Washington, D.C., August 29-September 2, 1983.

Mitra, Sanká: Robert S. Foote, Michael J. Fillenwarth, Bimal C. Pal, Abraham W. Hsie, and Charles T. Hadden. Adaptive response of bacteria and mammalian cells to N-methyl-N'-nitro-N-nitroso-guanidine. Radiation Research Soclety, San Antonio, Texas, February 27-March 3, 1983.

Mitra, Sankar, Robert S. Foote, and Chárles T. Hadden. Adaptive response In Bacillus subtilis. UCLA Symposia, Keystone, Colorado, April 10-15, 1983.

Moore, K. L., and P. A. Lalley. Comparative mapping in man and baboon (Papio papio) involving genes assigned to human chromosomes 4, 6, 14 , 15 and 20. VIIth International Workshop on Human Gene Mapping, Los Angeles, Callfornia, August 21-27, 1983.

Mykles, Donald L., and Dorothy M. Skinner. Crab calcium-dependent protelnase that degrades acting, myosin, and other myofibrillar proteins. American Society of Blological Chemists, San Prancisco, California, June 5-9, 1983.

Mykles, D. L., and D. M. Skinner. Crustacean $\mathrm{Ca}^{2+}$-dependent proteinase that degrades actin, myosin, and other myofibrillar proteins. American Soclety for Cell Biology, Baltimore, Maryland, $=$ veuber 30-December 4, 1982. 
Mykles, D. L., and D. M. Skinner. Role of $\mathrm{Ca}^{2+}$-dependent proteinase in proecdysial claw muscle atrophy. American Society of Zoologists, Louisville, Kentucky, December 27-30, 1982.

Nix, C. E., and L. C. Waters. Influence of genotype on mutation induction In Drosophila melanogaster. Environmental Mutagen Society, San Antunio, Texas, March 3-6, 1983.

Olins, D. E., A. L. Olins, H. A. Levy, R. C. Durfee, S. M. Margle, E. P. Tinnel, and S. D. Dover. Electron microscope tomography: transcription in 3-D. American Society for Cell Biology, Baltimore, Maryland, Noveuber 30-December 4, 1982.

O'Ne111, J. P., M. W. Heartlein, and R. J. Preston. SCE and gene mutation are induced by the replication of BrdU and CldU-substituted DNA. Environmental Mutagen Society, San Antonio, Texas, March 3-6, 1983.

Ou, C. Y., L. R. Boone, Gloria Boone, and W. K. Yang. A novel mousespecific interdispersed short repetitive sequence found in the LTK of mouse Mulv-related proviral sequences of mouse genome. Cold Spring Harbor Symposium, Cold Spring Harbor, New York, May 25-29, 1983.

Ou, C. Y., L. R. Boone, and W. K. Yang. Sequence characterization of the genetic determinants of $\mathrm{N}$ - and $\mathrm{B}$-tropism in murine leukemia viruses. American Society of Biological Chemists, San Francisco, California, June 5-9, 1983.

Perking, E. H., and P. L. Glover. Sequential thymus grafting of aged mice: characterization of growth, regression and enrichment of immune competence. Gerontological Sociaty of America, Boston, Massachusetts, November $19-23,1982$.

Perkins, E. H., K. K. Peterson, P. L. Glover, and R. E. Hand, Jr. Macrophage dependency of the proliferative response of human $T$ cell subpopulations stimulated with PHA and Con A: Quantitative differences. Federation of American Societies for Experimental Biology, Chicago, Illinois, April 10-15, 1983.

Popp, D. M., and R. A. Popp. The use of an in vivo mutation assay system to quantitate somatic mutation rate in murine hemopoletic stem cells. Envi- ,nmental Mutagen Society, San Antonio, Texas, March 3-6, 1983.

Popp, R. A., E. G. Balliff, L. C. Skow, F. M. Johnson, and S. E. Lewis. Analysis of a mouse $\alpha-g$ lobin gene mutation induced by ethylnitrosourea. Environmental Mutagen Society, San Antonio, Texas, March 3-6, 1983.

Popp, R. A., L. C. Skow, F. M. Johnson, S. E. Lew1z, W. F. Anderson, and S. 2. Goldberg. Mouse model of beta thalassemia. Gordon Research Conference, New London, New Hampsh1re, August 15, 1983. 
Preston, R. J. In vitro and in vive cytogenetic effects. Seninars on Ethylene Oxide Worker Safety, Chicago, Illinois, October 4-5, 1982.

Recio, L., B. Chastenay, R. I. Albertini, and A. W. Hsie. Detection of 6-thioguanine resistant s;leenocytes from Chinese hansters. Environmental Mutagen Society, San Antonio, Texas, March 3-6, 1983.

Rothrock, Robin, Kenneth R. Isham, Kai-Lin Lee, and Francis T. Kenney. Activation of hepatic differentiation by 5-azacytidine. American Society of Biolngical Chemists, San Francisco, Callfornia, June 5-9, 1983.

Russell, W. L., and P. R. Hunsicker. Extreme sensitivity of one particular germ-cell stage in male mice to Induction of specific-locus mutations by methylnitrosourea. Envi ronmental Mutagen Society, San Antonio, Texas, March 3-6, 1983.

Schnelder, U., and P. 'tazur. Changes in cell volume of mammalian zygotes under hyperosmotic or hypoosmotic conditions. Society for Cryobiology, Cambridge, England, August 30-September 2, 1983.

Schnelder, U., P. Mazur, and S. Lelbo. The permeability of day 7 bovine embryos to DMSO or glycerol. Society for Cryobiology, Cambridge, England, August 30-September 2, 1983.

Schultz, T. W., and J. N. Dumont. Comparative embryotoxicity and teratcgenicity of several potential osteolathyrogenic agents. American Microscopical Society, Louisville, Kentucky, December 27-30, 1982.

Sega, Gary A. Unscheduled DNA synthesis in germ cells of the male mouse. Genetic Toxicology Association, Cherry Hill, New York, November 4, 1982.

Sega, Gary A., C. R. Rohrer, and H. R. Harvey. Chemlcal dosimetry of ethylnitrosourea in the mouse testis. Environmental Mutagen Society, San Antonio, Texas, March 3-6, 1983.

Selby, Paul B. Dominant skeletal mutation test. Genetic Toxicology Assoctation, Cher.y Hill, New Jersey, May 4, 1983.

Selby, P. B., S. L. Niemann, S. Hitotosumachi, D. A. Carpenter, and W. L. Russell. Non-breeding-test methods for studying induction of dominant skeletal mutations found to work on another mouse strain. Environmental Mutagen Socfety, San Antonfo, Texas, March 3-6, 1983.

Shah, Y. B., R. L. Manger, and C. A. Heckman. Cytoskeletal proteins from tumorigenic and nontumorigenic rat respiratory tract eptthellal cells. Awerican Society for Cell Blology, Baltimore, Maryland, November 30Deceinber $4,1982$. 
Shugart, Lee, J. M. Holland, R. O. Rahn, and John Kao. Dosimetry of PAH skin carcinogenesis: mouse skin in organ culture as a shori-term bioassay system. Gordon Research Conference, New London, New Hampshire, June 27-July 1, 1533.

Shugart, Lee, and Iohn Kao. Ellagic acid decreases benzo(a)pyrene-binding to epiderwal DNA of mouse thin in organ culture. American Society of Biological Chemists, San Francisco, California, June 5-9, 1983.

Skinner, Dorothy M., Richard F. Powler, and Veta Bonnewell. Sequence variations occur close to homoco- or homopolymers in a G+C-rich complex satellite DNA. American Society of Biological Chemists, San Franrisco, Cáiffornia, June 5-9, 1983.

Skinner, D. M., R. F. Fowler, and V. Bonnewell. ' tes of divergence in the sequence of a complex satellite DNA and sevíal cloned variant. UCLA Symposium, Keystone, Colorado, April 3-9, 1983.

Skow, L. C., B. A. Burkhart, F. M. Johnson, R. A. Popp, S. Z. Goldberg, W. F. Anderson, L. B. Barnett, and S. E. Lewis. Inheritance, hematology anci molecular analysis of a $\beta$-thalassemia mutation in mice. Twelfth Blochemical Genetics Workshop, Bar Harbor, Maine, August 29September 2, 1983.

Snow, Elizabeth T., Robert S. Foote, and Sankar Mitra. Role of DNA polymerases in the base-pairing pattern of $0^{6}$-methylguanine during In vitro DNA replication. UCLA Symposia, Keystone, Colorado, April $\overline{10}-\overline{15,1983 .}$

Skow, L. C., R. A. Popp, F. M. Johnson, S. E. Lewis, S. Goldberg, B. A. Burkhart, W. F. Anderson, and L. Barnett. 52nd Annual Meeting, Genetics Socfety of America, St. Louls, Missour1, June 12-16, 1983.

Soumoff, C., and D. M. Skinner. In vitro assay of hydroxylase activity in the crab Gecarcinus lateralis. American Society of Zoologists, Loulsville, Kentucky, December 27-30, 1982.

Stankowski, L. F., Jr., R. S. Foote, S. Mitra, and A. W. Hsie. 06-Methyl dGTP and mutagenesis in the CHO/HGPRT assay. Environmental Mutagen Soclety, San Anton1o, Texas, March 3-6, 1983.

Stankowsk1, L. F., Jr., K. R. Tindall, R. Machanoff, and A. W. Hsie. An analysis of gene mutation in DNA transformed mammalian cells. American Society of Biological Chemists, San Francisco, California, June 5-9, 1983.

Stringfellow, Leslle, Ka1-Lin Lee, and Francis T. Kenney. Characterization of tyrosine aminotransferase Induction by cyclic AMP using a cloned cDNA probe. American Society of Blological Chemists, San Francisco, Callf ornia, June 5-9, 1983. 
Tindall, Renneth R., and A. H. Hsie. pSV2gpt transformed CHO cells. UCT Apri1 10-15, 1983.

Tindal1, R. R., L. F. Stankowsk1, Jr., R. Machanoff, and A. H. Hsie. Analysis of wutation In DNA transformed Chinese hanster ovary cells. Environmental Mutagen Soclety, San Antonio, Texas, March 3-6, 1983.

Tong, S., and J. R. Selkirk. Mutagenicity of benzo(a)pyrene, 6-nitrobenzo(a)pyrene and 10-azabenzo(a)pyrene in the $V-79$ Chinese hamster cell system and their metabolism by irradiated hanster enbryonic fibroblasts. American Association for Cancer Research, San Dfego, Callfornia, May 25-28, 1983.

v1lrich, R., and S. Ethier. Mammary tuworigenesis after exposure to radiation and 7,12-dimethylbenzanthracenes. Seventh International Congress of Radiation Research, Ansterdan, The Netherlands, July 3-8, 1983.

U11rich, R. L., and J. B. Storer. Dose rate effects after exposure to f1ssion neutrons. Radiation Research Suclety, San Antonio, Texas, February 27-March 3, 1983.

U11rich, R. L., J. B. Storer, and R. J. M. Fry. DOE life-span radiation effect studies in mice at Oak Ridge National Laboratory. Twenty-second Hanford Life Sciences Symposium, RIchland, Washington, September 27-29, 1983.

Uziel, Mayo, and A. Butler. Additive toxic responses on exposure of HEC to $\mathrm{Ni}(+2)$ and BAP. American Society of Biological Chemists, San Francisco, Callfornia, June 5-9, 1983.

Van Wyck, D., R. Popp, J. Foxley, M. Witte, C. Witte, and W. Crosby. Spontaneous Iron overload in $\alpha$-thalassemic mice. American Federation of Clinical Research, Washington, D.C., Apr11 29-May 2, 1983.

Wasilenko, W. J., and A. C. Marchok. The effect of reestablishing tissuelike cell associations on hexose uptake in rat tracheal epitheilal cell 11 nes and primary cell cultures. American Society for Cell Blology, Baltimore, Ma. 'and, November 30-December 4, 1982.

We1, C. H. The crystal structure of 4-methy1-5-pyraziny1-3h-1,2-dithiole3-thione. American Crystallographic Association, La Jolīa, Calffornia, August $16-20,1982$.

Wels8, R. R., and J. S. Cook. Pathways for efflux of hexoses during differentiation of $\mathrm{LLC}^{-\mathrm{PK}_{1}}$ cells in culture. American Soclety for Cell Blology, Baltlmore, Maryland, November 30-December 4, 1982.

Hitsch1, Hanspeter. Problems of toxicological testing of environmental complex mixtures. Third International Congress on Toxicology, San D1ego, Cal1forn1a, August 28-September 3, 1983. 
Financial Summary and Personnel Distribution

FY 1983

\begin{tabular}{|c|c|c|c|}
\hline Funding Source & $\begin{array}{l}\text { Punding in } \\
\text { thousands }\end{array}$ & $\begin{array}{l}7 \text { of total } \\
\text { budget }\end{array}$ & Person-years \\
\hline Department of Energy & 13,265 & 76.3 & 153.0 \\
\hline National Cancer Institute & 1,437 & 8.3 & 18.4 \\
\hline Environmental Protection Agency & 667 & 3.8 & 12.0 \\
\hline $\begin{array}{l}\text { National Institute of Environmental } \\
\text { Health Sciences }\end{array}$ & 1,168 & 6.7 & 13.9 \\
\hline Department of Defense & 506 & 2.9 & 7.4 \\
\hline $\begin{array}{l}\text { National Institute of General } \\
\text { Medical ScIences }\end{array}$ & 65 & 0.4 & 0.9 \\
\hline Department of Agriculture & 46 & 0.3 & 0.1 \\
\hline Mscel laneous & 228 & 1.3 & 4.3 \\
\hline TOTAL & 17,382 & & 210.0 \\
\hline
\end{tabular}


ORNL-6021

Distribution Category UC -48

INTERNAL DISTRIBUTION

1. T. D. Anderson

2. S. I. Auerbach

3. W. E. Barnett

4. J. L. Epler

5. G. G. Fee

6. R. J. M. Fry

7. W. Fulkerson

8. C. W. Gehrs

9-158. R. A. Griesemer

159. M. R. Guerin

160. F. C. Hartmari

161. D. W. Jared

162. S. V. Kaye

163. C. Krause

164. D. C. Parzyck

165. W. E. Porter

166. H. Postma
167-168. C. R. Richmond

169. G. D. Robbins

170. L. B. Russell

171. W. D. Shults

172. K. W. Sommerfeld

173. R. C. Ward

174. M. K. Wilkinson

175. H. R. Witschi

176. Biology Library

177-194. Biomedical Graduate School

195-196. Central Research Library

197. ORNL-Y-12 Technical Library

Document Reference Section

198-199. Laboratory Records Department

200. Laboratory Records, ORNL, RC

201. ORNL Patent office

202-204. Technical Publications

Department, ORNL

EXTERNAL DISTRIBUTION

205. El1zabeth L. Anderson, Director, Office of Health and Environmental Assessment, U.S. Environmental Protection Agency, 401 M Street, SW, Washington, DC 20460

206. Robert R. Applesnn, Director, Division of Sponsored Research,

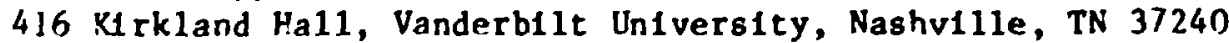

207. James R. Beal1, Health Effects Research Division, ER-72, Office of Health and Environmental Research, DOE, GTN, Washington, DC 20545

208. C. E. Carter, Sclentific Director, National Institute of Environmental Health Sclences, Research Triangle Park, NC 27709

209. John A. Cooper, Assistant D1rector foi Extramural Activities, Division of Cancer Cause and Prevention, National Cancer Institute, Landow BIdg., Room 8C41, Bethesda, MD 20205 
210. F. L. Culler, Electric Power Research Institute, 3412 Hillview Avenue, P.O. Box 10412, Palo Alto, CA 94303

211. Vincent T. DeVita, Jr., Director, National Cancer Institute, National Cancer Program, 9000 Rockville Pike, Bethesda, M 20205

212. Thaddeus J. Domanski, Chief, Chemical and Physical Carcinogenesis Branch, National Cancer Institute, Landow BIdg., Room 8C29, Bethesda, MD 20205

213. George G. Duda, Health Effects Research Division, ER-72, Gffice of Health and Environnental Research, DOE, GTN, Washington, DC 20545

214. Chief, Biological Carcinogenesis Branch, National Cancer Institute, Landow B1dg., Room 9A22, Bethesda, MD 20205

215. A. Paul Duhamel, Physical and Technological Research Division, ER-74, GTN, DOE, Washington, DC 20545

216. C. H. Edington, Associate Director, Office of Health and Environmental Research, ER-70, DOE, GTN, Washington, DC 20545

217. W. Gary Flam, Acting Associate Director for Toxicological Sciences, HFF (100), Bureau of Foods, Food and Drug Administration, 200 C Street, SW, Hashington, DC 20204

218. David Friedman, of fice of Solid Waste, U.S. Environmental Protection Agency, 2108 Wateralide Mall, Washington, DC 20460

219. William Frietsch, III, Deputy Director, Energy and Air Division, U.S. Environmental Protection Agency, Health Ef fects Research Laboratory, 26 West St. Clair, Cincirnati, Ohio 45268

220. Robert Gordon, Special Assistant to the Director, Bldg. 1, Room 235, National Institutes of Health, 9000 Rockville Pike, Bethesda, MD 20205

221. Robert Goyer, Deputy Director, National Institute of Envi ronmental Health Sciences, P.0. Box 12233, Research Triangle Park, NC 27709

222-291. John Haffey, Oak Ridge Associated Universities, Oak Ridge, TN 37830

292. Ronald W. Hart, Director, National Center for Toxicological Research, Jefferson, AR 72079

293. Bruce Hildebrand, Deputy, Environment, Safety, and Occupatio.lal Health, Office of the Assistant Secretary (IL \& FM), Department of the Army, The Pentagon, Washington, $D C 20301$

294. William C. Hilles, of fice of the Administrator, The Johns Hopkins Oncology Cencer, 600 North Wolfe Street, Baltimore, MD 21205

295. William A. Hoffman, Jr., Director, Oak Ridge Science Semester, GLCA, Denison University, Main Street, Graiville, OH 43023

296. Bernard L. Horecker, Roche I.sticute of Molecular Biology, Nutley, NJ 07110

297. Lawrence J. Jenkins, Ir., CDR, MSC, LSN, Officer-in-Charge, Naval Medical Research Institute, Toxicology Detachment, WrightPatterson Alr Force Base, Dayton, OH 45433

298. Beth Jinkerson, University Programs Division, Oak Ridge Associated Universities, Oak Ridge, TN 37830

299. David Longfellow, Program Director, Molecular Carcinogenesis Section, Division of Cancer Cause and Prevention, NIH, Landow B1dg., Room 8C29, Bethesda, MD 20205 
300. Boris Magasanik, Department of Biology, Massachusetts Institute of Technology, Cambridge, MA 02139

301. Ian Marceau, Deputy Assistant Secretary of Defense, Energy, Environment, and Safety, OASD (MRA \& L), 30823, The Pentagos, Washington, DC 20301

302. Ernest E. McConnell, National Toxicology Progran, National Institute of Environmental Health Sciences, P. 0. Box 12233, Research Triangle Park, NC 27709

303. W. D. McElroy, University of Calffornia, San Dfego, La Jolla, CA 92093

304. Martin Minthorn, Jr., Director, Health Effects Research Division, ER-72, Office of Health and Envi ronmental Research, DOE, GTN, Washington, DC 20545

305. A. Alan Moghissi, Office of Environmental Processes and Effects Research (RD-682), U.S. Envi ronmental Protection Agency, 401 M Street, SW, Washington, DC 20460

306. John A. Moore, U.S. Environmental Protection Agency, 401 M Street, SW, Washington, DC 20460

307. Gordon Newell, Senior Program Manager, Electric Power Research Insticute, 3412 Hillview Avenue, P.0. Box 10412, Palo Alto, CA 94303

308. Vauri Newi11, Medical Research Division, EXXON, P.0. Box 45, Linisen, NJ 07036

309. W. R. Ney, Executive Director, National Couricil on Radiation Protection and Measurements, 7910 Hoodmont Avenue, Sufte 1016, Washington, DC 20014

310. Norbert Page, National Library of Medicine, 8600 Rockville Pike, Bethesda, MD 20209

311. Ralph Perhac, Electric Power Research Institute, 3412 Hillview Avenue, P.0. Box 10412, Palo Alto, CA 94303

312. Henry C. Pitot, McArdle Laboratory for Cancer Research, University of Wisconsin, Madison, WI 53706

313. Richard E. Poulson, Laramie Energy Technology Center, DOE, P.0. Box 3395, Unj.versity Station, Laramie, WY 82071

314. Peter W. Preuss, Deputy Associate Executive Director for Health Sciences, U.S. Consumer Product Safety Commission, Washington, DC 20207

315. Michael J. Prival, Genetic Toxicology Branch, Food and Drug Administration, 200 C Street, SW, Washington, DC 20204

316. David P. Ral1, Director, National Institute of Enviro:umental Health Sciences, P.0. Box 12233, Research Triangle Park, NC 27709

317. Gerald J. Rausa, office of Heal h Research, RD 683, U.S. Envizonmental Protection gency, Washington, DC 20450

318. Thomas Roderick, The Jacksion saboratory, Bar Harbor, ME 04609

319. Leonard A. Sagan, Electric Power Research Institute, 3412 Hillview Avenue, P.0. Box 10412, Palo Alto, CA 94303

320. Robert T. Schimke, Department of Biological Sciences, Stanford University, Stanford, CA 94305

321. Murray Schulman, Manager, $R$ \& D Coordination, Office of Health and Environmental Research, ER-70, DOE, GTN, Washington, DC 20545 
322. David A. Sonith, Deputy Director, Health Effects Research

Division, ER-72, Office of Health and Environmental Research, DOE, GTN, Hashington, DC 20545

323. George E. Stapleton, Health Effects Research Division, ER-72, Office of Health and Environmental Research, DOE, GTN, Washingtor, DC 20545

324. R. W. Tennant, Chief, Cellular Genetic Toxicology Bzanch, National Institutes of Environmental Health Sciences, P. 0. Box 12233, Research Triangle Park, NC 27709

325. Alvin W. Trivelpiece, Director, Office of Energy Research, DOE, 1000 Independence Avenue SW, Hashington, DC 20585

326. Arthur C. Upton, Institute of Environmental Medicine, New York University Medical Center, 550 First Avenue, New York, NY 10016

327. Peter E. Voytek, Director, Reproductive Effects Assessment Group, RD 689, U.S. Environmental Protection Agency, Washington, DC 20460

328. Michael D. Waters, Director, Genetic Toxicology Division, MD-67, ORD/HERL, U.S. Environmental Protection Agency, Research Triangle Park, NC 27711

329. Neill Weaver, Director of Health and Biological Sciences, American Petroleum Insticute, 2101 L Street, NW, Washington, DC 20037

330. Gerald N. Hogan, Department of Nutrition and Food Sciences, Massachusetts Institute of Technology, Cambridge, MA 02139

331. Robert W. Wood, Director, Physical and Technological Research Division, ER-74, DOE, GTN, Washington, DC 20545

332. James B. Wyngaarden, Di rector, National Institutes of Health, Bldg. I, Room 124, 9000 Rockville Pike, Bethesda, MD 20205

333. National Library of Medicine, TSD Serials, 8600 Rockville Pike, Bethesda, MD 20209

334. Office of Assistant Manager for Fnergy Research and Development, DOE, Oak Ridge Operatiuns office, P.0. Box E, Oak Ridge, TN 37831

335-481. Given distribution as shown in TID-4500 under Biology and Medicine category, UC-48

( 25 copies - NTIS) 